\title{
TRACE METAL CONTAMINATION DUE TO ACID ROCK DRAINAGE AND ITS IMPACTS ON THE FISH-BEARING PENNASK CREEK WATERSHED IN BRITISH COLUMBIA
}

\author{
by \\ LISA DAWN WALLS \\ B.Sc. (Honours), The University of Guelph, 2002 \\ G.Dip.Tch., The University of Canterbury, 2003 \\ A THESIS SUBMITTED IN PARTIAL FULFILLMENT OF \\ THE REQUIREMENTS FOR THE DEGREE OF \\ MASTER OF APPLIED SCIENCE \\ in \\ The Faculty of Graduate Studies \\ (Civil Engineering)
}

THE UNIVERSITY OF BRITISH COLUMBIA

(Vancouver)

July 2010

(C) Lisa Dawn Walls, 2010 


\section{ABSTRACT}

Acid rock drainage (ARD) and associated metal leaching (ML) is a major pollution problem throughout the world, adversely affecting both surface and ground waters. The elevated concentrations of metals in the water column due to ARD/ML can be transferred to abiotic and biotic components of an ecosystem and adversely affect the health of aquatic life. The Pennask Creek watershed, one of the most important rainbow trout-producing environments in British Columbia (BC), has been contaminated with ARD/ML as a result of highway construction.

This study was designed to comprehensively examine the Pennask Creek watershed ARD/ML problem and its environmental impacts by combining existing and newly gathered information. The overall objectives were to determine the extent of metal contamination of the water and sediments, the potential biological impacts of this contamination, the influence of local geology, and to estimate the potential risk to aquatic organisms.

Results show that metal concentrations in the water and sediments downstream of the ARD/ML source are higher than concentrations elsewhere in the watershed. Analysis of historical water quality data indicates that the concentrations of these metals have decreased markedly since 2004, due to remediation efforts. Metals of concern include $\mathrm{Al}, \mathrm{As}, \mathrm{Cu}, \mathrm{Mn}, \mathrm{Ni}$ and $\mathrm{Zn}$.

Rock cuts along Highway 97C are generating ARD characterized by a low $\mathrm{pH}$ and high metal concentrations. Rock samples collected from the stream beds and banks were not found to be potentially acid-generating. However, these rock samples contained significant levels of metals of concern, which could continue to be leached under acidic conditions for many years to come.

$\mathrm{Al}, \mathrm{Cu}$, and $\mathrm{Zn}$ levels consistently exceeded $\mathrm{BC}$ and Canadian water and sediment quality guideline values for the protection of aquatic life, indicating that adverse biological effects are probable at sites downstream of the ARD/ML source. Benthic invertebrate monitoring over a ten year period shows low abundance and diversity, and a complete absence of sensitive taxa at downstream sites. Risk quotients indicate a likelihood of adverse biological effects for aquatic organisms, including rainbow trout, due to metal contamination in the watershed. 


\section{TABLE OF CONTENTS}

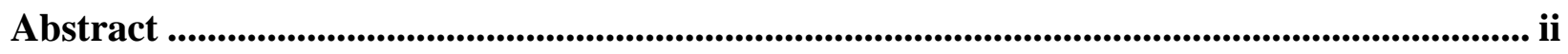

Table of Contents..........................................................................................................................ii

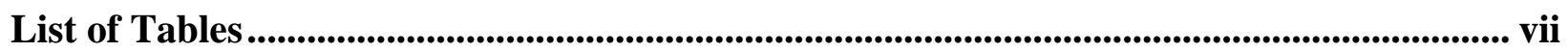

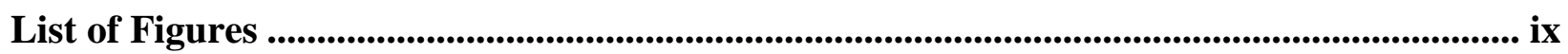

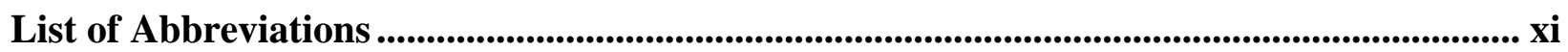

Acknowledgements .............................................................................................................. xii

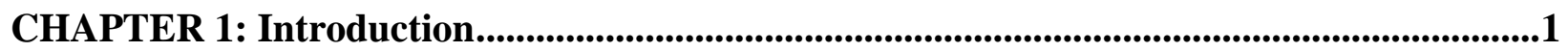

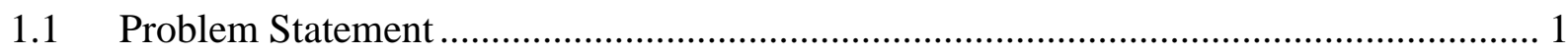

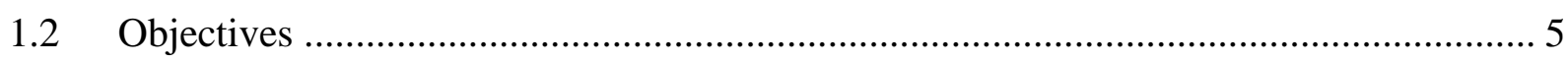

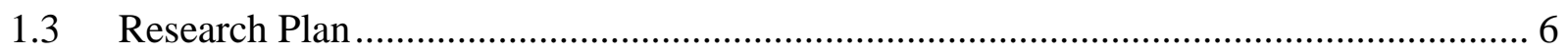

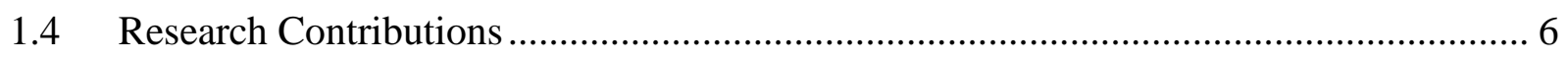

CHAPTER 2: Background ..........................................................................................................8

2.1 Generation of Acid Rock Drainage and Metal Leaching ................................................. 8

2.2 Impacts of ARD and Metal Contamination on Aquatic Life ........................................ 10

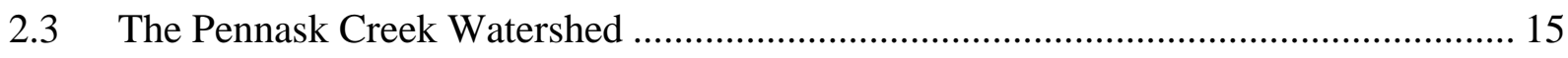

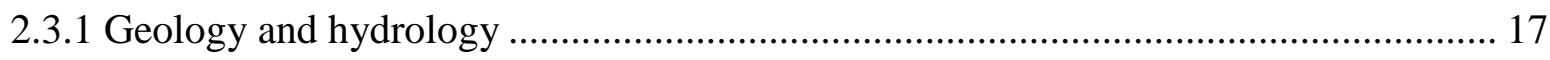

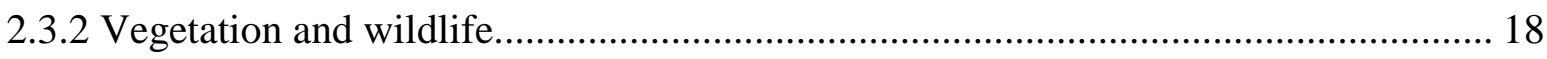

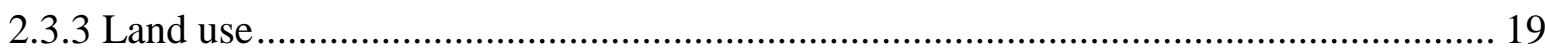

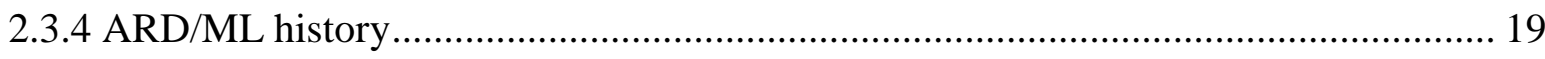

CHAPTER 3: Materials and Methods..........................................................................................................23

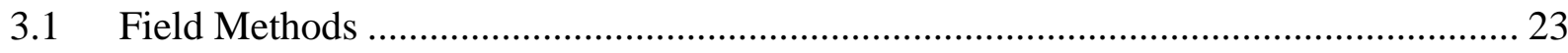

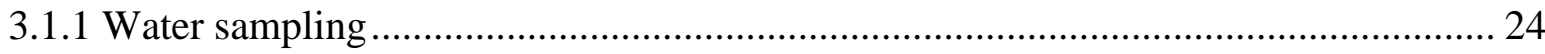

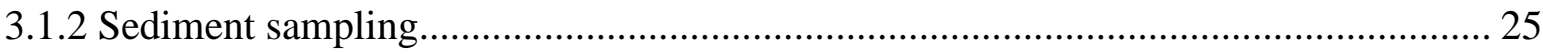




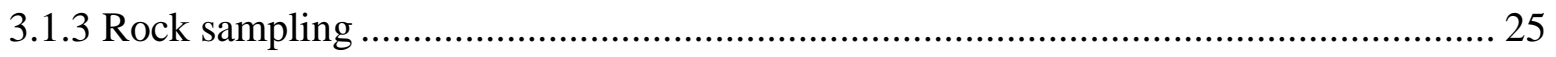

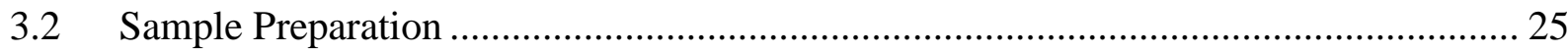

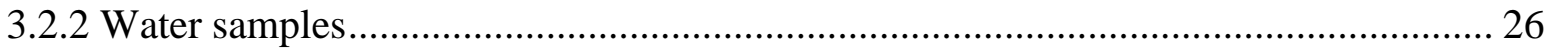

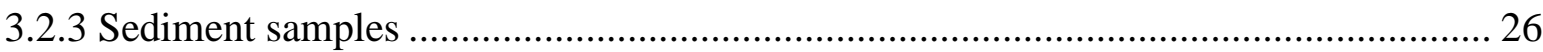

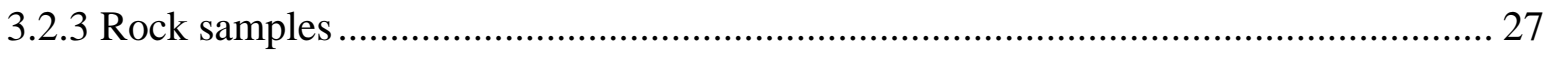

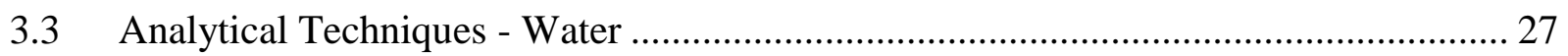

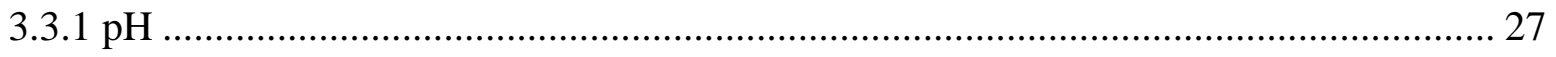

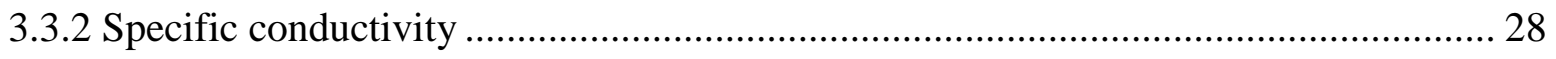

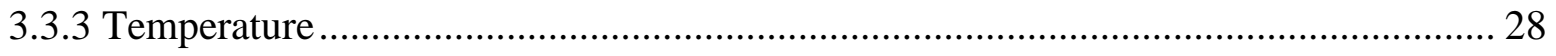

3.3.4 Dissolved oxygen ............................................................................................. 28

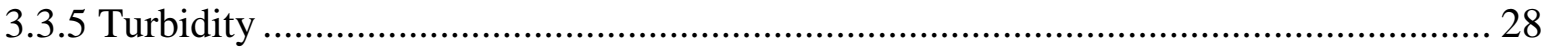

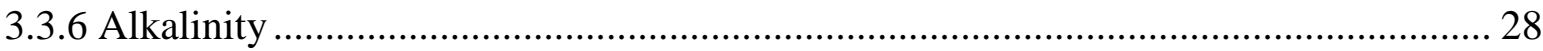

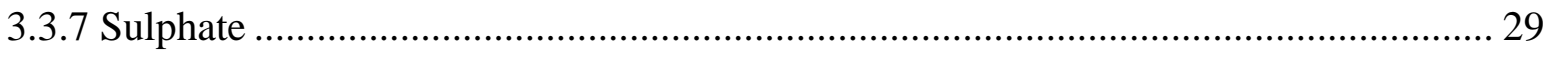

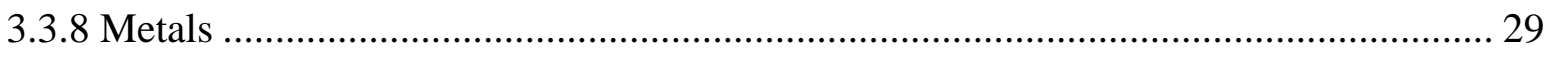

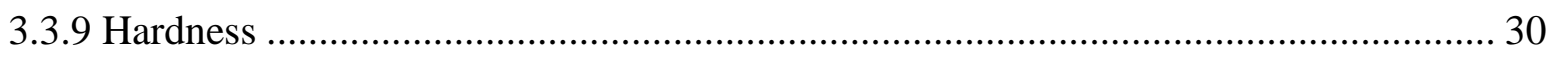

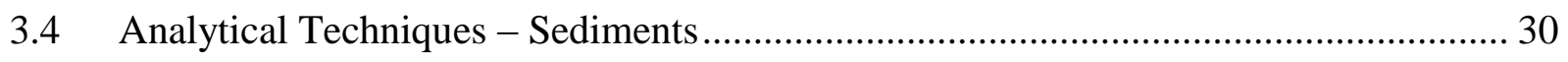

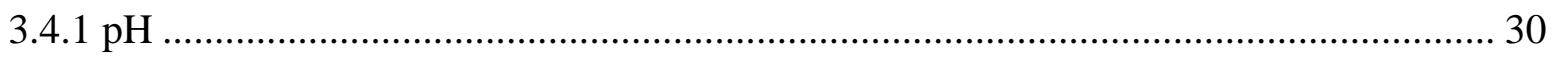

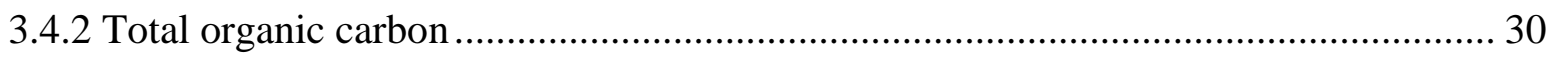

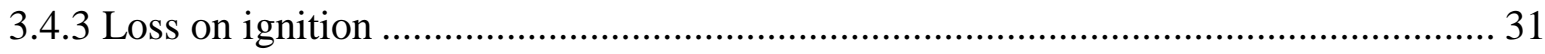

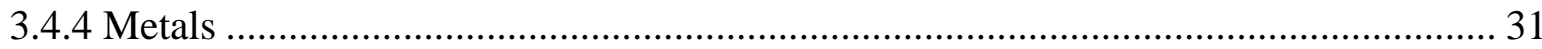

3.5 Analytical Techniques - Rocks ……………………............................................... 33

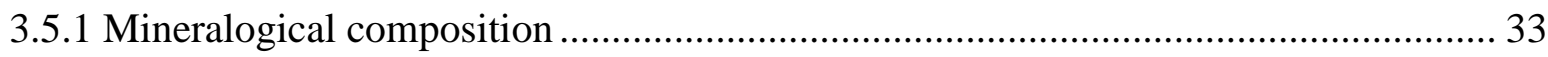

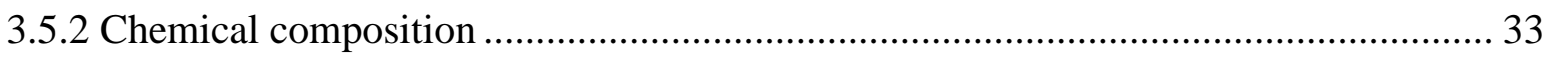

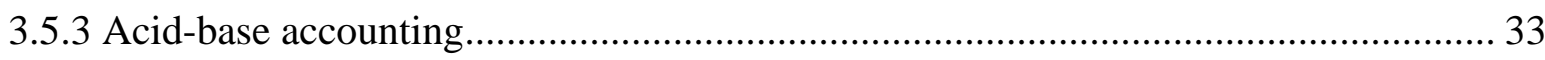

3.6 Compilation of Existing Water Quality and Benthic Invertebrate Data ......................... 33 


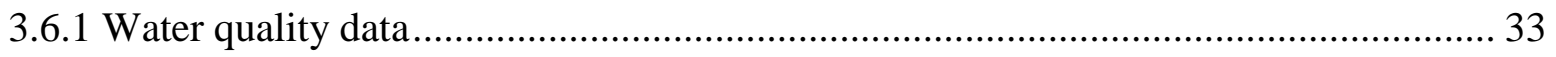

3.6.2 Benthic macroinvertebrate data .................................................................... 34

3.7 Microtox ${ }^{\mathrm{TM}}$ Solid Phase Toxicity Test.................................................................. 35

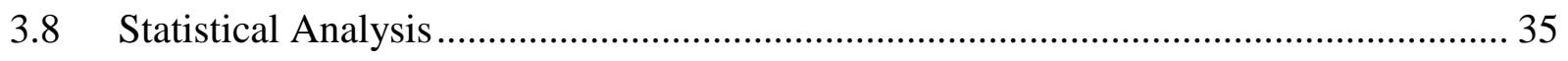

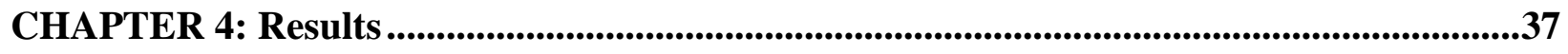

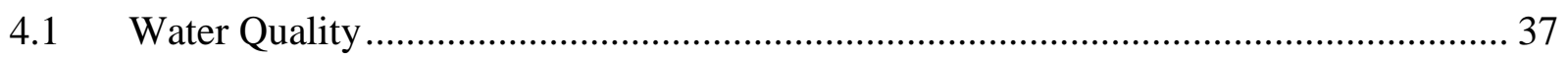

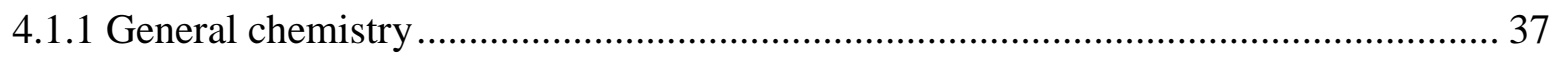

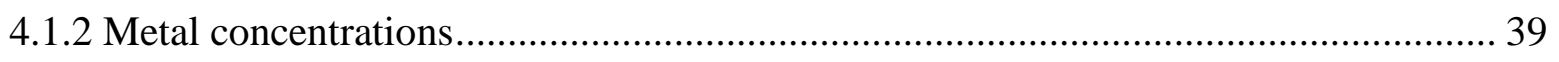

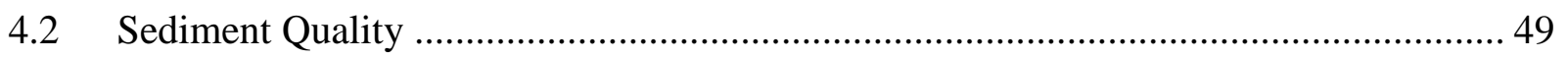

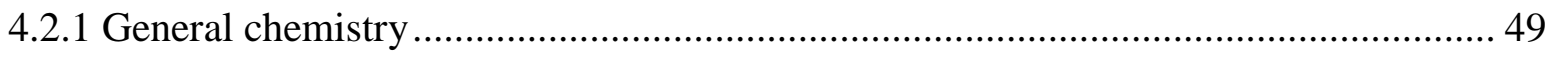

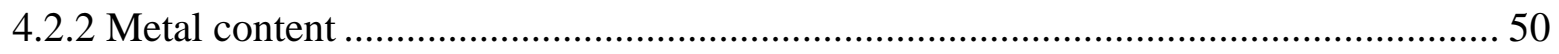

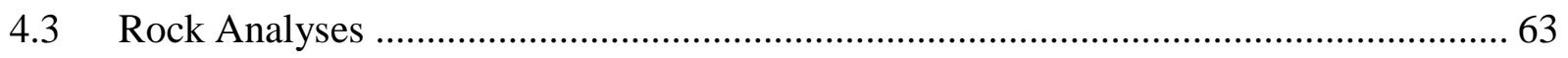

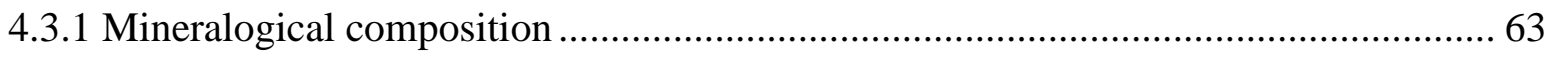

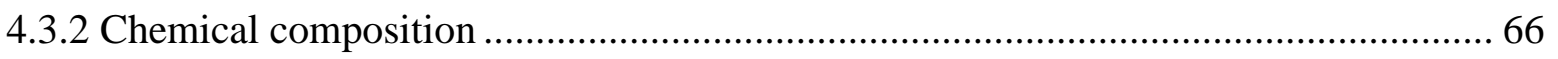

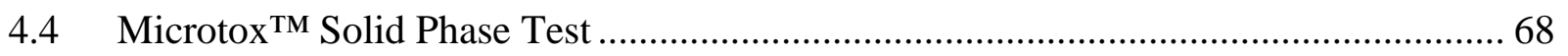

4.5 Statistical Comparison of July and September Samples ........................................ 68

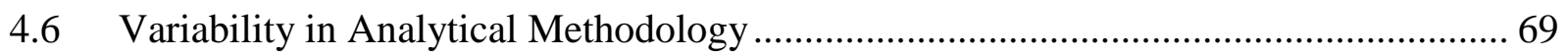

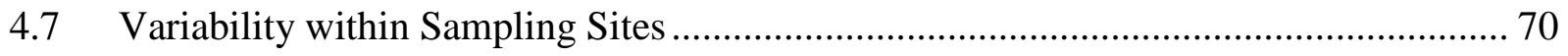

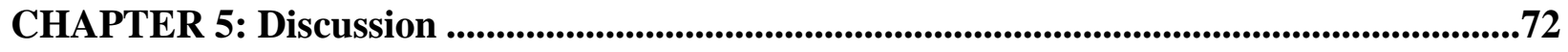

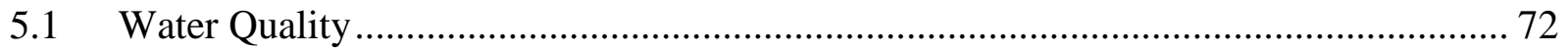

5.1.1 Spatial and temporal variability of general water chemistry …............................ 72

5.1.2 Spatial and temporal variability of trace metal concentrations .............................. 74

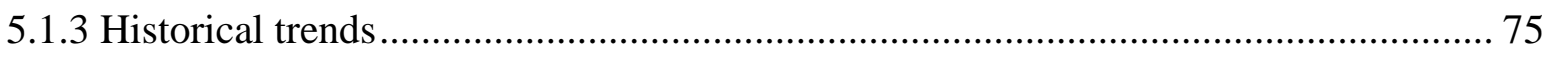

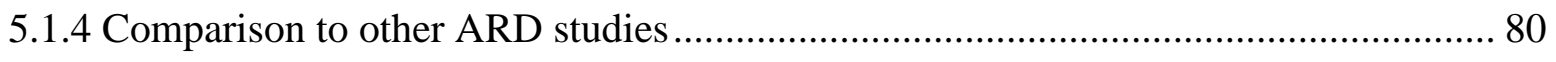

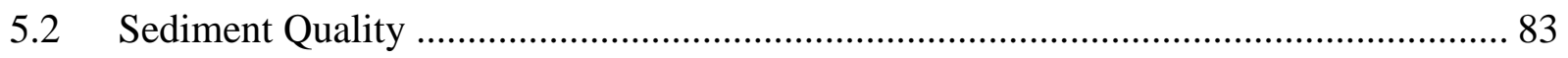


5.2.1 Spatial variability of general sediment properties ......................................... 83

5.2.2 Spatial variability of sediment metal content ................................................ 83

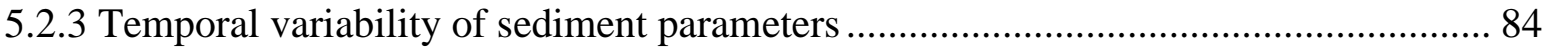

5.2.3 Comparison to other ARD studies ................................................................ 84

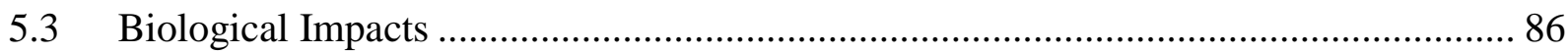

5.3.1 Benthic macroinvertebrate monitoring .......................................................... 86

5.3.2 Comparison to water quality guidelines and toxicity literature ............................. 90

5.3.3 Comparison to sediment quality guidelines and toxicity literature ........................ 93

5.3.4 Toxic effect to luminescent bacteria.............................................................. 96

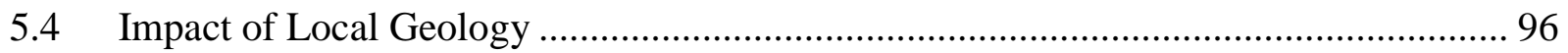

5.5 Estimation of Risk Posed to Rainbow Trout........................................................... 98

5.5.1 Problem formulation and exposure assessment ............................................ 98

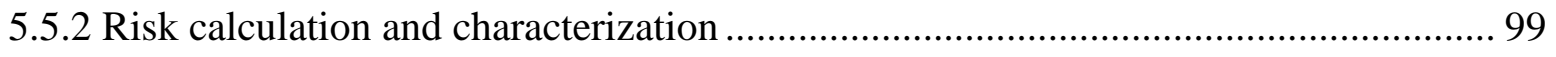

CHAPTER 6: Conclusions and Recommendations...........................................................102

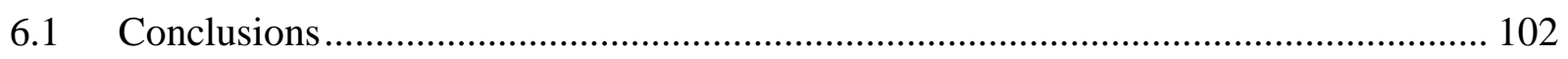

6.1.1 Extent of trace metal contamination in water and sediments ............................... 102

6.1.2 Biological impacts of trace metal contamination ........................................... 102

6.1.3 Impact of Highway 97C construction and local geology ................................... 103

6.1.4 Estimation of risk to aquatic organisms......................................................... 103

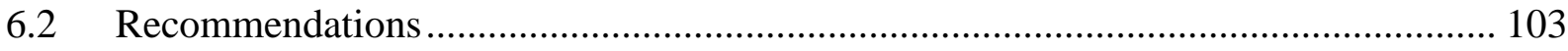

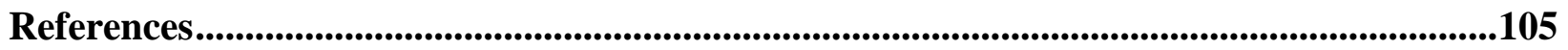

Appendix A: Water and Sediment Data Tables ............................................................................114

Appendix B: Wilcoxon Signed-Rank Test Tables.........................................................................124

Appendix C: Sample X-Ray Diffractogram ......................................................................................125

Appendix D: Quality Assurance/Control Data ....................................................................126 


\section{LIST OF TABLES}

Table 2.1: Water quality guidelines for the protection of aquatic life.................................. 14

Table 2.2: Sediment quality guidelines for the protection of aquatic life .............................. 15

Table 2.3: Studies examining ARD/ML in the Pennask Creek watershed..............................20

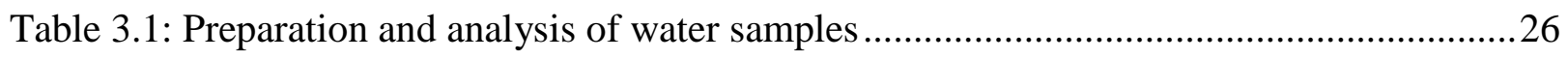

Table 3.2: Preparation and analysis of sediment samples ................................................22

Table 3.3: List of metals analyzed and associated ICP-OES detection limits for water samples

Table 3.4: List of metals analyzed and associated ICP-OES detection limits for sediment

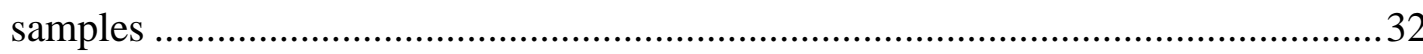

Table 4.1: Summary of total metal concentrations detected in July water samples ..................40

Table 4.2: Summary of dissolved metal concentrations detected in July water samples ............40

Table 4.3: Summary of total metal concentrations detected in September water samples..........41

Table 4.4: Summary of dissolved metal concentrations detected in September water samples.. 41

Table 4.5: Total metal content of July sediment samples (strong acid leachable) ....................51

Table 4.6: Total metal content of September sediment samples (strong acid leachable)............52

Table 4.7: Extractable metal content of July sediment samples (weak acid) ..........................53

Table 4.8: Extractable metal content of September sediment samples (weak acid)................. 54

Table 4.9: Proportion of July total metal content that is extractable ......................................63

Table 4.10: Proportion of September total metal content that is extractable...........................63

Table 4.11: Ideal formulae of minerals present in Pennask Creek watershed rock samples.......64

Table 4.12: Results of qualitative XRD analyses of Pennask Creek watershed rock samples....65

Table 4.13: Results of XRF analyses of Pennask Creek watershed rock samples ....................67

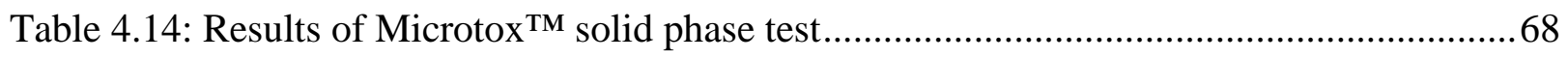

Table 4.15: Average ratio of duplicate analyses for total metals concentrations by

ICP-OES for water samples

Table 4.16: Measurement of the precision and accuracy of the total metals digestion and

ICP technique using the certified reference material MESS-3 (NRC) ...................70

Table 5.1: Comparison of water quality data from Pennask Creek watershed to water quality data from ARD-impacted streams in other studies. 82 
Table 5.2: Comparison of sediment total metals content data from Pennask Creek watershed to data from ARD-impacted streams in other studies

Table 5.3: Relative abundance of EPT organisms to total abundance of benthic macroinvertebrates in the Pennask Creek watershed (sites H1, H2, H3, P4, P5) from 2000-2009

Table 5.4: Risk quotients calculated for $\mathrm{Al}, \mathrm{Cu}$, and $\mathrm{Zn}$ in the water column of Pennask

Creek 100

Table A1: General water quality characteristics for July water samples 114

Table A2: General water quality characteristics for September water samples 114

Table A3: Total metal concentrations in July water samples . 115

Table A4: Dissolved metal concentrations in July water samples 116

Table A5: Total metal concentrations in September water samples

Table A6: Dissolved metal concentrations in September water samples 118

Table A7: General sediment characteristics for July samples 119

Table A8: General sediment characteristics for September samples

Table A9: Total metal content of July sediment samples (strong acid leachable)

Table A10: Total metal content of September sediment samples (strong acid leachable)....

Table A11: Extractable metal content of July sediment samples (weak acid)

Table A12: Extractable metal content of September sediment samples (weak acid)

Table B1: Wilcoxon Signed-Rank Test $p$-values for water samples

Table B2: Wilcoxon Signed-Rank Test $p$-values for sediment samples

Table D1: Measurement of the precision of total metal concentrations in water samples using ICP-OES by comparison of duplicate analysis on two different instruments. 


\section{LIST OF FIGURES}

Figure 1.1: Map showing the location of Pennask Creek and Highway Creek.........................3

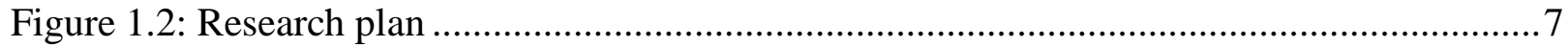

Figure 2.1: Stages in the formation of acid rock drainage .............................................. 8

Figure 2.2: The major effects of ARD on a lotic system .............................................. 11

Figure 2.3: Map showing the approximate boundary of the Pennask Creek watershed.............. 16

Figure 2.4: Photograph of ARD flowing from rock cut on south side of Highway 97C towards Highway Creek 17

Figure 3.1: Location of water, sediment and rock sampling stations ...................................2 24

Figure 4.1: Dissolved aluminum concentration $(\mathrm{mg} / \mathrm{L})$ in water samples...............................4 42

Figure 4.2: Total copper concentration $(\mathrm{mg} / \mathrm{L})$ in water samples .......................................43

Figure 4.3: Total iron concentration $(\mathrm{mg} / \mathrm{L})$ in water samples ...........................................4

Figure 4.4: Total magnesium concentration $(\mathrm{mg} / \mathrm{L})$ in water samples ..................................45

Figure 4.5: Total manganese concentration $(\mathrm{mg} / \mathrm{L})$ in water samples..................................46

Figure 4.6: Total nickel concentration $(\mathrm{mg} / \mathrm{L})$ in water samples........................................4

Figure 4.7: Total zinc concentration $(\mathrm{mg} / \mathrm{L})$ in water samples...........................................48

Figure 4.8: Aluminum content $(\mathrm{mg} / \mathrm{kg}, \mathrm{dw})$ of sediment samples .....................................55

Figure 4.9: Arsenic content $(\mathrm{mg} / \mathrm{kg}, \mathrm{dw})$ of sediment samples .........................................56

Figure 4.10: Copper content $(\mathrm{mg} / \mathrm{kg}, \mathrm{dw})$ of sediment samples........................................57

Figure 4.11: Iron content $(\mathrm{mg} / \mathrm{kg}, \mathrm{dw})$ of sediment samples ...........................................58

Figure 4.12: Magnesium content $(\mathrm{mg} / \mathrm{kg}, \mathrm{dw})$ of sediment samples...................................59

Figure 4.13: Nickel content $(\mathrm{mg} / \mathrm{kg}, \mathrm{dw})$ of sediment samples ..........................................60

Figure 4.14: Zinc content $(\mathrm{mg} / \mathrm{kg}, \mathrm{dw})$ of sediment samples

Figure 4.15: Mean and standard deviation of several water quality parameters (July) for all sample sites $(n=8)$ compared to single sample sites H1B and H3 $(n=3) \ldots \ldots \ldots . .71$

Figure 5.1: $\mathrm{pH}$ values in the Pennask Creek watershed (sites H1, H2, H3, P4) from

October 2000 to October 2009 .76

Figure 5.2: Specific conductance values in the Pennask Creek watershed

(sites H1, H2, H3, P4) from October 2000 to October 2009 .76 
Figure 5.3: Dissolved aluminum concentration in the Pennask Creek watershed

(sites H1, H2, H3, P4) from October 2000 to October 2009

Figure 5.4: Total copper concentration in the Pennask Creek watershed

(sites H1, H2, H3, P4) from October 2000 to October 2009 .78

Figure 5.5: Total manganese concentration in the Pennask Creek watershed

(sites H1, H2, H3, P4) from October 2000 to October 2009 .78

Figure 5.6: Total nickel concentration in the Pennask Creek watershed

(sites H1, H2, H3, P4) from October 2000 to October 2009 .79

Figure 5.7: Total zinc concentration in the Pennask Creek watershed

(sites H1, H2, H3, P4) from October 2000 to October 2009

Figure 5.8: Total number of benthic macroinvertebrates captured in the Pennask Creek watershed (sites H1, H2, H3, P4, P5) from 2000 to 2009

Figure 5.9: Total number of benthic macroinvertebrate taxa (orders) captured in the

Pennask Creek watershed (sites H1, H2, H3, P4, P5) from 2000 to 2009 .88

Figure 5.10: Total number of EPT taxa captured in the Pennask Creek watershed

(sites H1, H2, H3, P4, P5) in 2008 and 2009

Figure 5.11: Conceptual site model for the Pennask Creek watershed .98

Figure C1: X-ray diffractogram of sample H1-A

Figure D1: Quality control chart for analysis of MESS-3 using Microtox ${ }^{\mathrm{TM}}$ solid

phase test 


\section{LIST OF ABBREVIATIONS}

$\begin{array}{ll}\text { ARD } & \text { acid rock drainage } \\ \text { BC } & \text { British Columbia } \\ \text { BCMOE } & \text { British Columbia Ministry of Environment } \\ \text { CCME } & \text { Canadian Council of Ministers of the Environment } \\ \text { EEC } & \text { estimated environmental concentration } \\ \text { EPT } & \text { Ephemeroptera, Plecoptera, Trichoptera } \\ \text { HDPE } & \text { high-density polyethylene } \\ \text { IC } & \text { inhibitory concentration (50\%) } \\ \text { ICP-OES } & \text { inductively coupled plasma - optical emission spectrometer/spectrometry } \\ \text { LOI } & \text { loss on ignition } \\ \text { ML } & \text { metal leaching } \\ \text { RQ } & \text { risk quotient } \\ \text { SPT } & \text { solid phase test } \\ \text { TOC } & \text { total organic carbon } \\ \text { TRANS } & \text { Ministry of Transportation and Infrastructure } \\ \text { TRV } & \text { toxicity reference value }\end{array}$

\section{Chemicals}

$\begin{array}{llllll}\mathrm{Ag} & \text { silver } & \mathrm{Fe} & \text { iron } & \mathrm{Mg} & \text { magnesium } \\ \mathrm{Al} & \text { aluminum } & \mathrm{FeS}_{2} & \text { pyrite } & \mathrm{Mn} & \text { manganese } \\ \mathrm{As} & \text { arsenic } & \mathrm{H}^{+} & \text {hydrogen ion } & \mathrm{Mo} & \text { molybdenum } \\ \mathrm{Ca} & \text { calcium } & \mathrm{H}_{2} \mathrm{SO}_{4} & \text { sulphuric acid } & \mathrm{Ni} & \text { nickel } \\ \mathrm{CaCO}_{3} & \text { calcium carbonate } & \mathrm{HCl} & \text { hydrochloric acid } & \mathrm{Pb} & \text { lead } \\ \mathrm{Cd} & \text { cadmium } & \mathrm{Hg} & \text { mercury } & \mathrm{Se} & \text { selenium } \\ \mathrm{Co} & \text { cobalt } & \mathrm{HNO}_{3} & \text { nitric acid } & \mathrm{SO}_{4} & \text { sulphate } \\ \mathrm{Cu} & \text { copper } & \mathrm{KCl} & \text { potassium chloride } & \mathrm{Zn} & \text { zinc }\end{array}$




\section{ACKNOWLEDGEMENTS}

I would like to express my sincerest thanks to my supervisor, Dr. Loretta Li, for her enthusiasm, guidance and patience throughout the course of this study. I wish to convey thanks to Dr. Ken Hall for his advice and involvement in all stages of this research. Dr. Li and Dr. Hall are also to be acknowledged for their prompt and constructive feedback during the final stages of preparing this thesis.

Paula Parkinson, Susan Harper, Timothy Ma, and Maureen Soon are to be acknowledged for their advice and assistance with the laboratory portions of this study. The help provided by Robinson Bancroft during the first sampling expedition is also greatly appreciated.

Financial support for this research was generously provided by the BC Ministry of Transportation and Infrastructure through Dr. Li.

The support and encouragement of my family and friends is also gratefully acknowledged. Finally, I'd like to thank my husband, Edward Walls, for his technical advice, assistance with field work, and his enduring patience and support throughout my graduate studies. 


\section{CHAPTER 1: INTRODUCTION}

\subsection{Problem Statement}

Acid rock drainage (ARD) is a major pollution problem throughout the world, adversely affecting both surface and ground waters (Gerhardt 1993, Gray 1996, Caruso and Dawson 2009). ARD occurs when sulphide-rich minerals are exposed to the weathering effects of oxygen and water (Lacelle et al. 2007). Any naturally occurring or human-induced activity that disturbs mineralized materials can result in ARD (Munk et al. 2002, Todd et al. 2007). Elevated metal leaching (ML) is often associated with ARD due to the high solubility of many metals under acidic conditions (McKnight and Bencala 1990).

ARD/ML has caused significant ecological damage and resulted in multi-million-dollar cleanup costs for the mining industry and governments (DeNicola and Stapleton 2002, Egiebor and Oni 2007). Once conditions conducive to ARD/ML generation have been established, significant environmental impacts can persist for hundreds of years (BCMWLAP 2002, Grande et al. 2005, Egiebor and Oni 2007).

The elevated concentrations of metals in the water column due to ARD/ML can be transferred to abiotic and biotic components of an ecosystem and adversely affect the health of aquatic life (Farag et al. 2007). Metals that are absorbed by plant and animal tissue (bioaccumulation) can be passed from one organism to another through the food web, with concentrations of metal contaminants in tissue increasing with trophic level (biomagnification).

ARD is a problem most commonly associated with mining activities in Europe, Asia, Africa, and the Americas (Gray 1996, DeNicola and Stapleton 2002, Egiebor and Oni 2007, Farag et al. 2007, Trois et al. 2007, Butler 2009, Wu et al. 2009). However, there are cases of ARD generation due to natural processes, as well as anthropogenic activities such as airport and highway construction worldwide (Mathews and Morgan 1982, Fox et al. 1997, Orndorff and Daniels 2004, Grande et al. 2005, Todd et al. 2007). Pennask Creek, located in British Columbia (BC), Canada is one such case of ARD/ML pollution due to highway construction.

Pennask Creek (Figure 1.1) is one of the most important rainbow trout (Oncorhynchus mykiss) producing streams in BC. Much of the Pennask Creek watershed is located within the BC Parks Pennask Creek Protected Area, which was set aside in 2001 to protect the spawning and rearing 
habitat of this significant wild rainbow trout population (BCMWLAP 2003). Pennask Creek is an extremely important egg source for the provincial fish culture program. Each spring, eggs and milt are collected from $10 \%$ of the 15,000 to 25,000 spawning rainbow trout, transported to a nearby fish hatchery where they are fertilized, hatched and reared before being released into hundreds of small lakes throughout the Southern Interior of BC. 

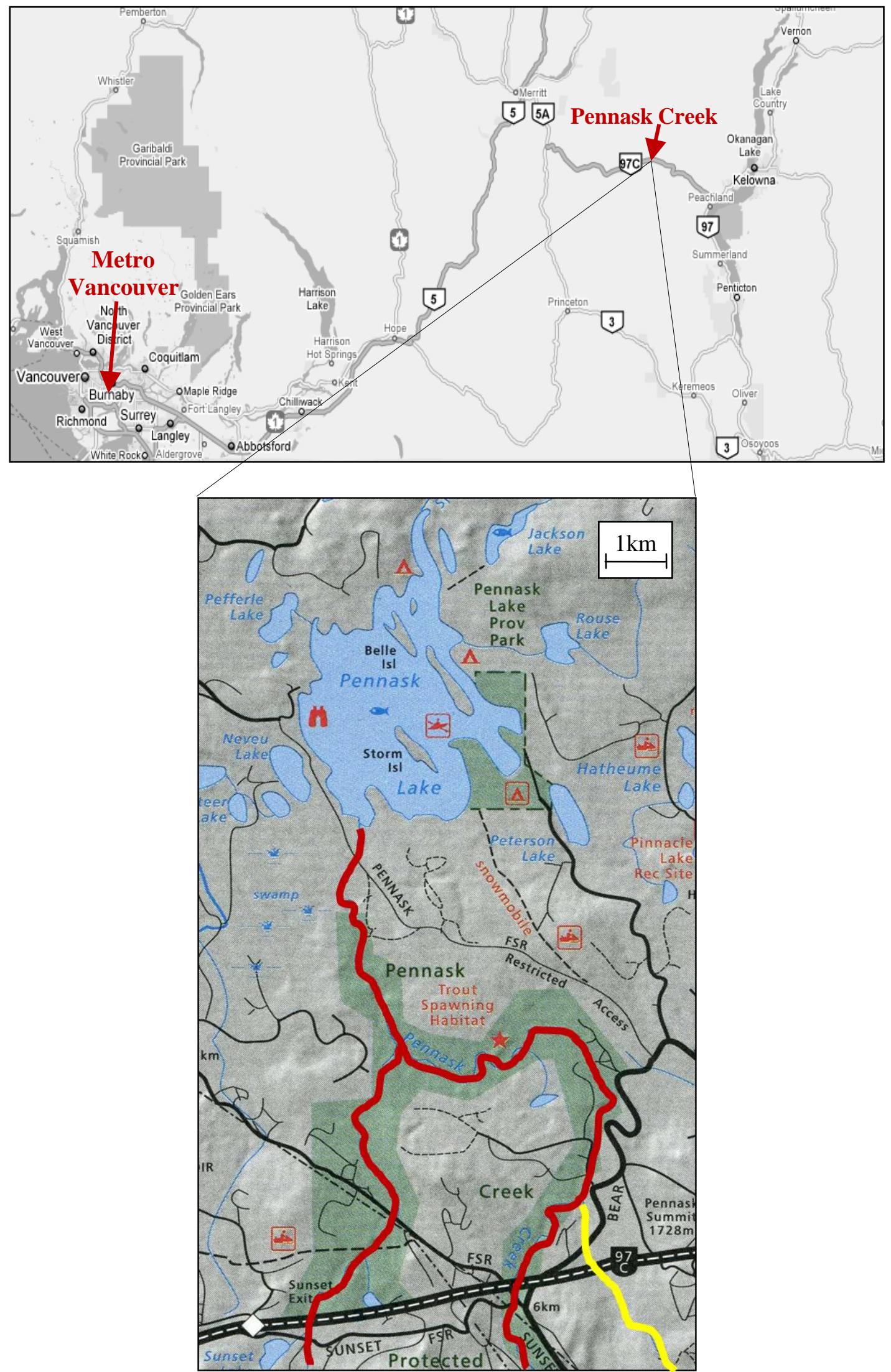

Figure 1.1: Map showing the location of Pennask Creek (red) and Highway Creek (yellow) 
Highway 97C, which bisects the Pennask Creek watershed, was constructed from 1987-1990. A relatively small amount of rock was excavated near an unnamed tributary (commonly and herein referred to as Highway Creek), which drains into the fish-bearing Pennask Creek. The location of Highway Creek is shown in Figure 1.1. This construction activity resulted in the exposure of a highly pyritic rock formation near Pennask Summit, alongside the highway. Eventually, these rock-cuts released ARD and elevated levels of ML into Highway Creek (Morin and Hutt 2007).

Since the construction of Highway 97C, it has been found that Highway Creek yields fewer invertebrates per sample site compared to sites downstream of its confluence with Pennask Creek (BWP 1999-2009). Downstream of the confluence of Highway Creek and Pennask Creek, the rainbow trout population has also declined significantly (BWP 1999-2009). Morin and Hutt (2003) assessed ARD and ML production in the Pennask and Highway Creek drainage areas and determined that leaching of aluminum $(\mathrm{Al})$, copper $(\mathrm{Cu})$ and zinc $(\mathrm{Zn})$ is of concern. Impacts from the flow of Highway Creek into Pennask Creek are noticeable downstream of the confluence, but other seepages and flows also appear to have detrimental impacts on the water quality of Pennask Creek before it enters Pennask Lake. The BC Ministry of Transportation and Infrastructure (TRANS) has an ongoing monitoring program for the ARD generated by Highway 97C construction and is actively seeking remediation solutions. At the present time, the drainage from the ARD-generating section of Highway 97C is being collected, treated and removed from the site, and no drainage is being discharged into Highway Creek.

Metals leached from rocks in the Pennask Creek watershed can be absorbed by fish and other aquatic organisms. Fish, including rainbow trout, are exposed to metals through diffusion into the bloodstream via the gills and skin, drinking contaminated water, eating contaminated sediments, or eating other organisms that have absorbed metals. Small concentrations can be toxic because metals undergo bioconcentration, which means that their concentration in an organism is higher than that in the surrounding water. Metal toxicity can adversely affect organisms' survival, activity, growth, metabolism, and/or reproduction (Wright and Welbourn 2002). Studies (DeNicola and Stapleton 2002, Dills and Rogers 1974, Dubé et al. 2005, Jeffree et al. 2001, Letterman and Mitsch 1978, Sanchez-España et al. 2005, Verb and Vis 2000) have demonstrated the impact of metal contamination from ARD on aquatic organisms, including fish species. 
Several studies have been conducted in an attempt to describe the ARD/ML problem in the Pennask Creek watershed. These studies were conducted by different parties (BWP 1999-2009, Grunenberg and Tomlinson 2001, Morin and Hutt 2003, Jia 2005, Li 2006-2007, Golder 20082009) and focused on different aspects of the ARD/ML problem, including geology, water quality, benthic invertebrates, and remediation. Sediment quality has not yet been investigated for the Pennask Creek watershed. No single study has examined the ARD/ML problem and its impacts comprehensively. In order to fully understand the ARD/ML problem in the Pennask Creek watershed, the local geology, water quality, sediment quality, and aquatic biota must be evaluated and examined together.

\subsection{Objectives}

This study is designed to comprehensively examine the Pennask Creek watershed ARD/ML problem and its environmental impacts. Specifically, this study will combine existing information concerning geology, water quality, and benthic invertebrate populations, with newly gathered information regarding geology, water and sediment quality.

The overall aims of this study are:

(1) to evaluate whether construction of Highway 97C alone or in combination with the background geochemical conditions, is the source of the ARD/ML problem, and

(2) to evaluate the risk posed to aquatic life from trace metal contamination in the watershed.

The specific objectives that will lead to reaching the aims of this study are:

- to characterize the mineralogy and chemical composition of rocks found in the Pennask Creek watershed.

- to determine the extent of trace metal contamination in the water and sediments of the Pennask Creek watershed.

- to determine the biological impacts of trace metal contamination in the water and sediments of the Pennask Creek watershed. 


\subsection{Research Plan}

In order to achieve the aims and objectives, a research plan was developed. A flowchart detailing this research plan is shown in Figure 1.2. The research includes sampling, field measurements, and laboratory analysis of surface water, stream sediments, and local rocks.

\subsection{Research Contributions}

This study is designed to comprehensively investigate the Pennask Creek watershed ARD/ML problem and its environmental impacts. The results of this study will show whether the construction of Highway 97C alone has caused the ARD/ML problem, or if the background geochemical conditions might be contributing. It will also add to the understanding of the mobility and bioavailability of metal contaminants in the Pennask Creek watershed and assist in evaluation of the risk posed to aquatic organisms, including rainbow trout. This information could subsequently be applied to other fish-bearing streams affected by ARD/ML. Once the Pennask Creek watershed ARD/ML problem is more fully understood, it will be possible to design a mitigation plan to reduce the impact of ARD/ML on the water and sediment quality and the rainbow trout population. 


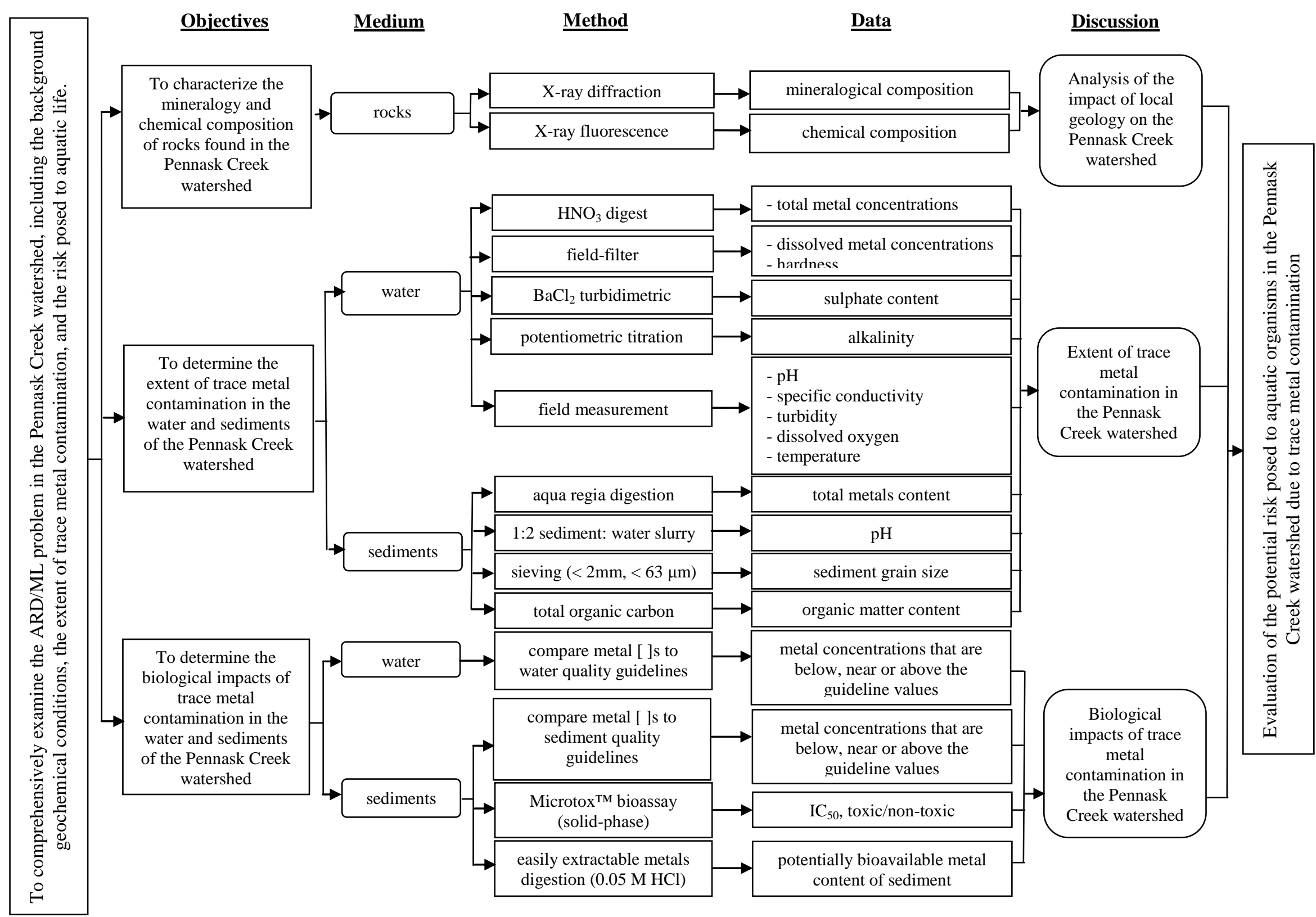

Figure 1.2: Research plan 


\section{CHAPTER 2: BACKGROUND}

\subsection{Generation of Acid Rock Drainage and Metal Leaching}

ARD occurs when sulphide-rich minerals, such as pyrite $\left(\mathrm{FeS}_{2}\right)$, are exposed to air and water (Gray 1996; Lacelle et al. 2007). The oxidation of pyrite is a complex process involving a series of redox reactions, hydrolysis, and complex ion formations that vary as a function of $\mathrm{pH}$. The generation of ARD can be viewed as a three-stage process defined by the $\mathrm{pH}$ of the water that is in contact with the sulphide minerals (Egiebor and Oni 2007). Figure 2.1 illustrates these three stages.

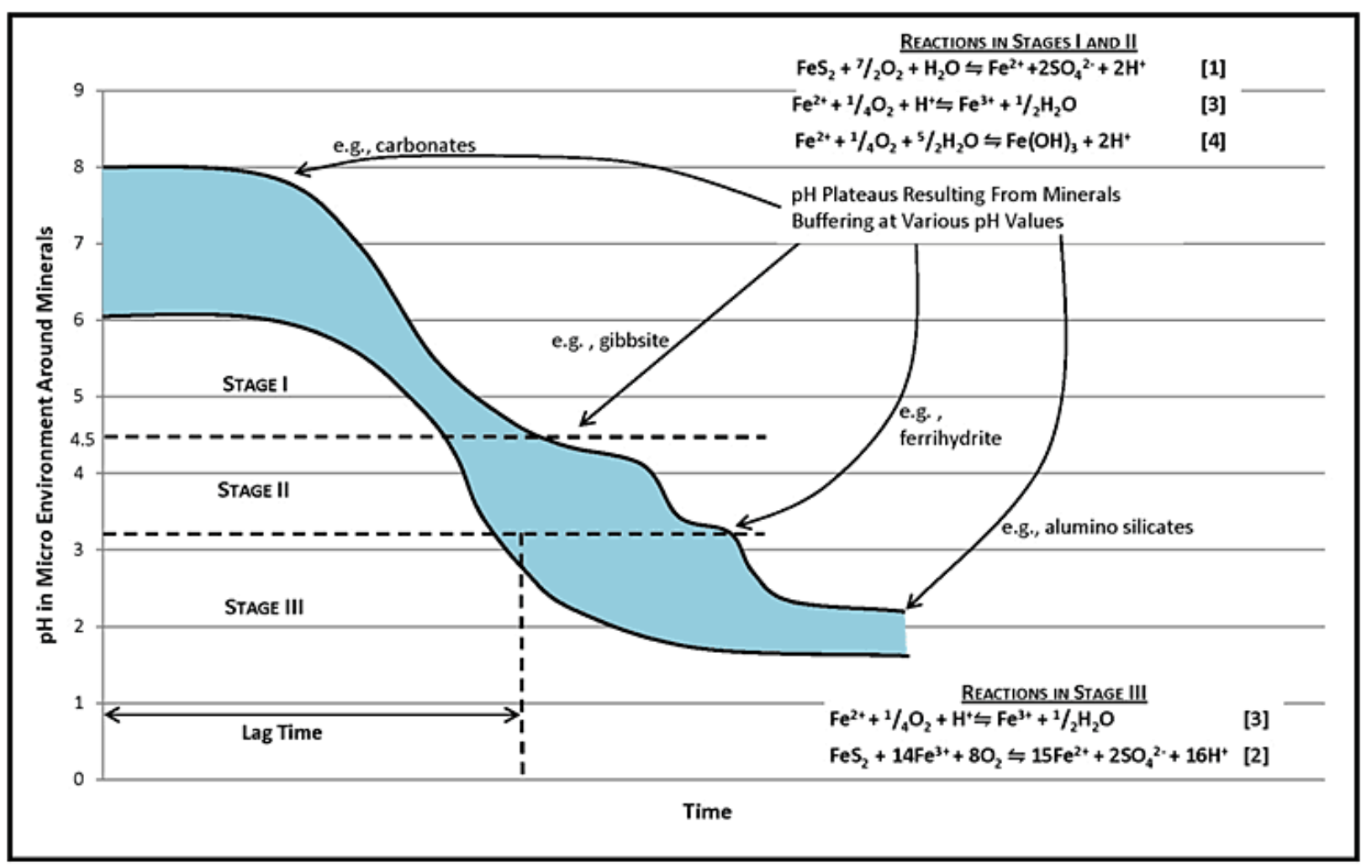

Figure 2.1: Stages in the formation of acid rock drainage (adapted from Broughton and Robertson 1992)

In stage I, pyrite reacts with water and oxygen to produce sulphuric acid through relatively slow chemical oxidation at near-neutral $\mathrm{pH}$. This reaction is shown in the equation below:

$$
2 \mathrm{FeS}_{2}+7 \mathrm{O}_{2}+2 \mathrm{H}_{2} \mathrm{O} \rightarrow 4 \mathrm{SO}_{4}^{2-}+2 \mathrm{Fe}^{2+}+4 \mathrm{H}^{+}
$$


Microbial oxidation of sulphide may also be catalyzed by acidophilic bacteria, such as Thiobacillus ferrooxidans (Egiebor and Oni 2007). Stage II occurs under weakly acidic pH conditions. Ferrous iron $\left(\mathrm{Fe}^{2+}\right)$ is oxidized to ferric iron $\left(\mathrm{Fe}^{3+}\right)$, which precipitates as ferric hydroxide, $\mathrm{Fe}(\mathrm{OH})_{3}$, and releases more acidity in the form of hydrogen ions $\left(\mathrm{H}^{+}\right)$, thus lowering the $\mathrm{pH}$ further. This process is shown in the following two equations:

$$
\begin{aligned}
& 4 \mathrm{Fe}^{2+}+4 \mathrm{H}^{+}+\mathrm{O}_{2} \rightarrow 4 \mathrm{Fe}^{3+}+2 \mathrm{H}_{2} \mathrm{O} \\
& \mathrm{Fe}^{3+}+3 \mathrm{H}_{2} \mathrm{O} \rightarrow \mathrm{Fe}(\mathrm{OH})_{3(\mathrm{~S})}+3 \mathrm{H}^{+}
\end{aligned}
$$

As the $\mathrm{pH}$ value falls to below 3.5, some ferric iron remains in solution and oxidizes additional pyrite directly, according to the following equation:

$$
\mathrm{FeS}_{2(\mathrm{~S})}+14 \mathrm{Fe}^{3+}+8 \mathrm{H}_{2} \mathrm{O} \rightarrow 15 \mathrm{Fe}^{2+}+2 \mathrm{SO}_{4}{ }^{2-}+16 \mathrm{H}^{+}
$$

Under the acidic conditions of stage III, T. ferrooxidans rapidly catalyzes the process by oxidizing further ferrous iron to ferric iron. This increases the overall rate of acid production by several orders of magnitude. A rapid cyclic process ensues, which produces large quantities of acid and an associated release of heavy metals into solution (Egiebor and Oni 2007). See Figure 2.1 for further details on the reactions that occur in Stages I, II and III.

Elevated ML is most commonly associated with ARD due to the high solubility of many metals under acidic conditions. However, environmental impacts can occur from ML under neutral or alkaline drainage conditions. This is the case particularly for geological materials with elevated levels of arsenic (As), molybdenum (Mo), selenium (Se), or Zn (BCMWLAP 2002). The specific metals found in ARD/ML flows vary depending on local geological factors. Studies conducted by Li $(2006,2007)$ indicate that the ARD/ML flow at the Highway 97C source has an acidic $\mathrm{pH}(3.0-3.6)$ and elevated concentrations of dissolved and total $\mathrm{Al}(12-24 \mathrm{mg} / \mathrm{L}), \mathrm{Cu}$ (0.05-0.20 mg/L), iron (Fe) (0.17-17.2 mg/L), and Zn (0.68-16.6 mg/L).

Since the mining industry is the most significant source of ARD/ML, research has been largely focused on mining-related ARD/ML. In Canada, 155 acid-generating mines have been identified (Feasby and Jones 1994). As of 1997, there were approximately 200 million tonnes of acidgenerating tailings and 420 million tonnes of acid-generating waste rock in BC, and these are increasing by 25 million tonnes per year (Feasby et al. 1997). It is estimated that the liability 
associated with existing Canadian tailings and waste rock is between $\$ 2$ and $\$ 5$ billion (Feasby and Tremblay 1995).

The generation of ARD/ML causes surface and ground waters to become highly acidic and enriched in sulphate $\left(\mathrm{SO}_{4}\right), \mathrm{Fe}$, and heavy metals (Gray 1996; Lacelle et al. 2007). Once initiated, ARD/ML may persist for hundreds of years (Arnesen and Iversen 1997). The release of metals into the environment as a result of ARD generation causes a disturbance in water quality and poses a major environmental threat to the health of plants, animals and humans.

\subsection{Impacts of ARD and Metal Contamination on Aquatic Life}

ARD runoff into lotic systems (moving water, such as rivers and streams) often results in adverse effects on resident biota (Butler 2009), including fish mortality, toxicity and stress (Todd et al. 2007), drastic reductions in benthic macroinvertebrate abundance and diversity (Dills and Rogers 1974, Letterman and Mitsch 1978), and significant changes in benthic algal communities (Verb and Vis 2000, DeNicola and Stapleton 2002). The effects of ARD on lotic systems can be categorized as chemical, physical, biological and ecological, however the overall impact on the biotic community structure is the elimination of species, thereby simplifying the food chain and reducing ecological stability (Gray 1997). Figure 2.2 illustrates the major effects of ARD on lotic systems. These effects are so diverse that community structure collapses rapidly and completely, even though in many cases no single pollutant would have caused such a severe ecological impact. Ecosystem recovery is suppressed due to factors such as habitat destruction, substrate modification, the toxic nature of the sediments, and/or bioaccumulation of metals in biota (Gray 1997). 


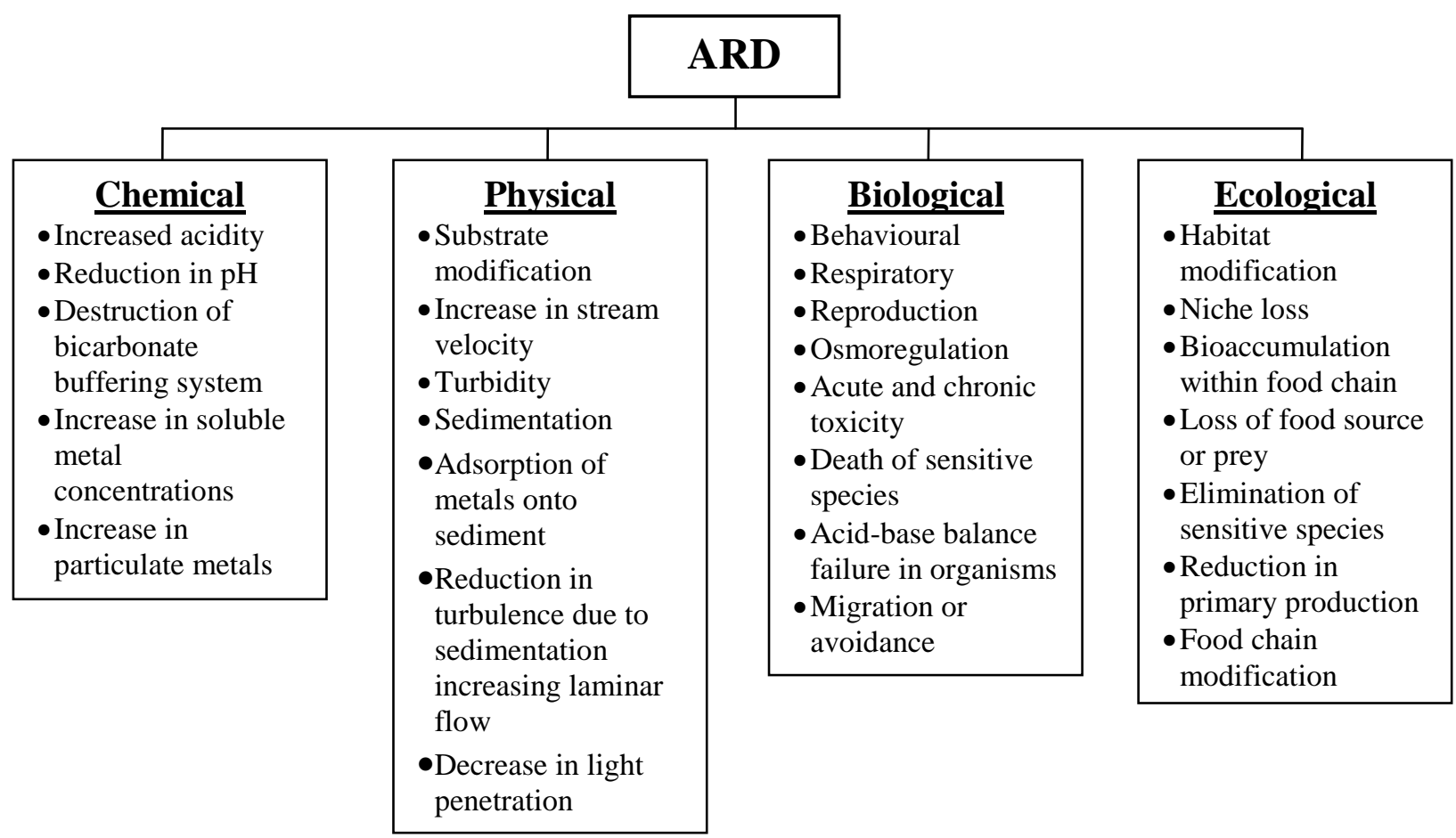

Figure 2.2: The major effects of ARD on a lotic system (Adapted from Gray 1997)

According to Gray (1997), the main factors to be considered in terms of the impacts of ARD are the acidity itself, sedimentation processes, and metal toxicity. As a multi-factor pollutant, the importance of each factor varies both within and between ARD-affected systems. The overall impact is mainly controlled by the buffering capacity of the receiving water and the available dilution rather than the nature of the ARD itself. The buffering capacity is a function of the alkalinity/acidity, $\mathrm{pH}$ and hardness of the lotic system, which when exhausted, can result in a reduction of $\mathrm{pH}$, species diversity, and the release of metals from minerals in the system. Sedimentation can affect a lotic system through toxicity, loss of habitat and species diversity, as well as increased turbidity.

In the context of freshwater impacted by ARD/ML, the metals of potential concern include silver (Ag), Al, As, cadmium (Cd), cobalt (Co), Cu, Fe, mercury (Hg), manganese (Mn), nickel (Ni), lead $(\mathrm{Pb})$, and $\mathrm{Zn}$; however, the specific metals of concern at each site vary depending on the local geology (Campbell and Stokes 1985, Gerhardt 1993, Griffith et al. 2004, Egiebor and Oni 2007, Todd et al. 2007). The degree of toxicity of these metals to aquatic organisms is determined by both abiotic (e.g. metal speciation, $\mathrm{pH}$, temperature and hardness) and biotic factors (e.g. organism size, weight, life stage, tolerance, uptake site, differences and interactions between species) (Gerhardt 1993). Toxicity is most related to uptake of the free ion form of the 
metal in the water or from food, and occurs when uptake exceeds the organisms' ability to regulate the metal or to bind it in a non-lethal form, such as to metallothionein (Campbell and Stokes 1985, DeNicola and Stapleton 2002, Gerhardt 1993, Hare 1992).

Metal species can be grouped into three phases: (1) aqueous phase - free ionic and soluble complexes, (2) solid phase - colloids and particles, and (3) biological phase - incorporated into cells or adsorbed to biological surfaces (Flemming and Trevors 1989). Metal speciation, partitioning, and bioavailability depend on physiochemical (e.g. temperature, complexing agents, stream flow, $\mathrm{pH}$ ) and biological (e.g. structure of cell surfaces, uptake and adsorption mechanisms) factors. The presence of complexing agents and adsorptive surfaces (e.g. humic acids, fine particulate organic matter, clay particles, and calcium carbonate $\left.\left(\mathrm{CaCO}_{3}\right)\right)$, for example, causes a decrease in the free ionic metal species, which are considered to be the most toxic (Gerhardt 1993).

As temperature increases, the toxicity of metals to aquatic biota generally increases (Wang 1987, Gerhardt 1993). Increased hardness (in the form of $\mathrm{CaCO}_{3}$ ) generally causes a decrease in toxicity due to either complexation of the metal ion with carbonates or competition between the metal ion and calcium or magnesium ions for binding sites on cell membranes (Wang 1987, Gerhardt 1993). Metal toxicity is affected by $\mathrm{pH}$ between values of 4 and 7 due to changes in metal speciation. For $\mathrm{Cd}, \mathrm{Cu}$, and $\mathrm{Zn}$, a decrease in $\mathrm{pH}$ results in decreased toxicity due to $\mathrm{H}^{+}$ competition for membrane binding sites or an $\mathrm{H}^{+}$effect on membrane potential. For $\mathrm{Pb}$, a decrease in $\mathrm{pH}$ results in increased toxicity due to increased metal availability (Campbell and Stokes 1985).

Changes in toxicity can occur at different stages in the life cycle of an organism. For example, exposure to sub-lethal levels of $\mathrm{Cu}$ can cause effects in juvenile salmon such as a reduction in swimming performance, lower growth rates, impaired sensory mechanisms, and reduced immunity (Barry et al. 2000). Some populations of a species may be more tolerant to a metal because of decreased uptake, increased excretion, or induced metallothionein production. This tolerance can be genetically based (an adaptation) when a population has lived in a contaminated environment for several generations, or it can be induced by gradual exposure to increasing metal concentrations (acclimation). Interactions between species, such as competition, predation, or parasitism, can also cause changes in the toxicity of a metal. The stress exerted on 
an organism or population because of these interactions may lead to an increased biological response to a pollutant by changes in tolerance levels (Gerhardt 1993).

Metals can exert adverse effects at several sites in an organism, including:

- Cell membrane - transport mechanisms can be disrupted by blocking carrier molecules or by replacing essential metals with a toxic metal ion (i.e. $\mathrm{Cu}$ affects the membrane permeability of fish gills, disrupting ionic and osmotic balance (Barry et al. 2000));

- Deoxyribonucleic acid (DNA) - damage to DNA can be caused by metals (i.e. exposure to Cd causes breakage of DNA strands in rainbow trout hepatocytes (Risso-de Faverney et al. 2001));

- Nervous system - electrical response of nerve cells can be depressed (i.e. exposure to $\mathrm{Cu}$ reduces the olfactory response in fish either by competing with natural odorants for binding sites, by affecting activation of the olfactory receptor neurons, or by affecting intracellular signalling in the neurons (Baldwin et al. 2003, McIntyre et al. 2008));

- Enzymes - enzyme actions can be inhibited by metals (i.e. carbonic anhydrase activity is inhibited by Cd exposure in freshwater rainbow trout (Bektas et al. 2008)).

In nature, metal pollution most commonly occurs as a mixture of different metals. Laboratory toxicity tests, however, generally consider metals individually. Since metals interact with one another, such studies may be inadequate for evaluating the toxic effects of metal pollution on an ecosystem. There are three types of interactions: (1) additivity - the combined effect of two or more metals equals the sum of the effects of the single metals, (2) synergism - the combined effect of two or more metals is greater than the sum of the effects of the single metals, (3) antagonism - the combined effect of two or more metals is less than the sum of the effects of the single metals. These types of interactions are an important consideration in investigations of ARD/ML-receiving waterways because discharges from ARD sources are typically characterized by complex mixtures of metals (Todd et al. 2007).

The Canadian Council of Ministers of the Environment (CCME) has developed the Canadian Environmental Quality Guidelines to provide nationally endorsed science based goals for the quality of atmospheric, aquatic, and terrestrial ecosystems. The Canadian Department of Fisheries and Oceans, Environment Canada, and the BC Ministry of Environment (BCMOE) work together to manage the water and sediment quality in BC. In order to regulate water and 
sediment quality, BCMOE has developed province-specific guideline values for the protection of aquatic life. Table 2.1 outlines the $\mathrm{BC}$ and CCME water quality guidelines for $\mathrm{pH}$, total alkalinity, sulphate content, and several relevant metal concentrations. Table 2.2 outlines the BC and CCME sediment quality guidelines.

Table 2.1 Water quality guidelines for the protection of aquatic life (BCMOE 2006, CCME 2007)

\begin{tabular}{|c|c|c|}
\hline Parameter & BC & CCME \\
\hline $\mathrm{pH}$ & $6.5-9.0$ & $6.5-9.0$ \\
\hline $\begin{array}{l}\text { Total Alkalinity } \\
\left(\mathrm{mg} \mathrm{CaCO}_{3} / \mathrm{L}\right)\end{array}$ & $\begin{array}{l}\text { - }<10 \rightarrow \text { highly sensitive to acid } \\
\text { inputs* } \\
\text { - } 10 \text { to } 20 \rightarrow \text { moderately sensitive to } \\
\text { acid inputs* } \\
>20 \rightarrow \text { low sensitivity to acid } \\
\text { inputs* }\end{array}$ & - \\
\hline $\begin{array}{l}\text { Sulphate Content } \\
\left(\mathrm{mg} \mathrm{SO}_{4} / \mathrm{L}\right)\end{array}$ & $\begin{array}{ll}\cdot & \text { Alert level }=50 \\
- & \text { Maximum }=100 \\
\end{array}$ & - \\
\hline $\begin{array}{c}\text { Aluminum } \\
\text { Concentration } \\
(\mathrm{mg} / \mathrm{L})\end{array}$ & $\begin{array}{ll}\text { - } & \text { dissolved concentration } \\
\text { - } & \mathrm{pH} \geq 6.5 \rightarrow 0.1 \\
\text { - } & \mathrm{pH}=6.3 \rightarrow 0.066 \\
\text { - } & \mathrm{pH}=6.4 \rightarrow 0.074\end{array}$ & $\begin{array}{ll}\text { - } & \mathrm{pH}<6.5 \rightarrow 0.005 \\
\text { - } & \mathrm{pH} \geq 6.5 \rightarrow 0.1\end{array}$ \\
\hline $\begin{array}{c}\text { Arsenic } \\
\text { Concentration } \\
(\mu \mathrm{g} / \mathrm{L}) \\
\end{array}$ & 2. & 5 \\
\hline $\begin{array}{c}\text { Cadmium } \\
\text { Concentration } \\
(\mu \mathrm{g} / \mathrm{L})\end{array}$ & $\begin{array}{l}\text { varies with hardness } \\
\text { - for Pennask Creek watershed: } \\
0.007-0.022^{*}\end{array}$ & $\begin{array}{l}\text { varies with hardness } \\
\text { for Pennask Creek watershed: } \\
0.007-0.022 *\end{array}$ \\
\hline $\begin{array}{c}\text { Copper } \\
\text { Concentration } \\
(\mu \mathrm{g} / \mathrm{L})\end{array}$ & $\begin{array}{l}\text { varies with hardness } \\
\text { - for Pennask Creek watershed: } 3.7 \text { - } \\
7.9\end{array}$ & $\begin{array}{l}\text { varies with hardness } \\
\text { - for Pennask Creek watershed, all } \\
\text { sites: } 2 \\
\end{array}$ \\
\hline $\begin{array}{l}\text { Iron Concentration } \\
(\mathrm{mg} / \mathrm{L})\end{array}$ & $\begin{array}{ll}\cdot & \text { Total Fe concentration }=1.0 \\
- & \text { Dissolved Fe concentration }=0.35\end{array}$ & 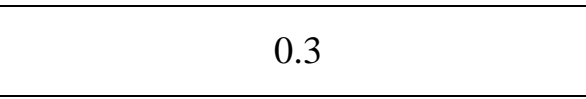 \\
\hline $\begin{array}{l}\text { Lead Concentration } \\
(\mu \mathrm{g} / \mathrm{L})\end{array}$ & $\begin{array}{l}\text { - varies with hardness } \\
\text { for Pennask Creek watershed: } 9.0 \text { - } \\
45.0\end{array}$ & 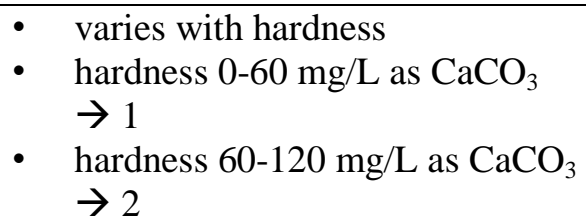 \\
\hline $\begin{array}{c}\text { Manganese } \\
\text { Concentration } \\
(\mathrm{mg} / \mathrm{L})\end{array}$ & $\begin{array}{l}\text { - } \quad \text { varies with hardness } \\
\text { - for Pennask Creek watershed: } 0.73 \\
-1.2\end{array}$ & 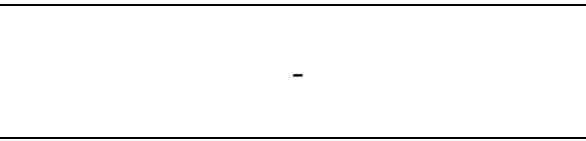 \\
\hline $\begin{array}{l}\text { Nickel Concentration } \\
(\mu \mathrm{g} / \mathrm{L})\end{array}$ & 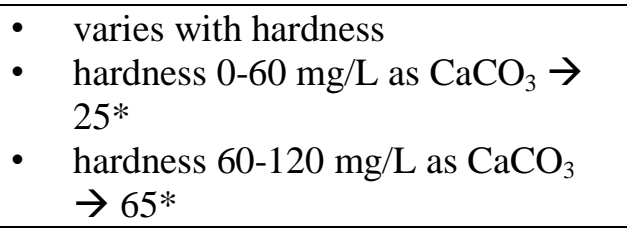 & 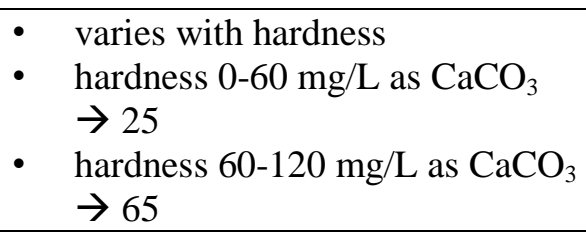 \\
\hline $\begin{array}{c}\text { Zinc Concentration } \\
(\mu \mathrm{g} / \mathrm{L})\end{array}$ & $\begin{array}{l}\text { - } \quad \text { varies with hardness } \\
\text { for Pennask Creek watershed, all } \\
\text { sites: } 33\end{array}$ & 30 \\
\hline
\end{tabular}

* working guideline value 
Table 2.2: Sediment quality guidelines for the protection of aquatic life (BCMOE 2006, CCME 2002)

\begin{tabular}{|c|c|c|c|c|}
\hline \multirow[t]{2}{*}{ Metal } & \multirow{2}{*}{\multicolumn{2}{|c|}{$\begin{array}{c}\text { BC Working Guidelines } \\
(\mu \mathrm{g} / \mathrm{g}, \text { dry weight })\end{array}$}} & \multicolumn{2}{|c|}{ CCME } \\
\hline & & & $I S Q G$ & PEL \\
\hline As & ISQG = 5.9 & PEL $=17$ & 5.9 & 17.0 \\
\hline Cd & $\mathrm{ISQG}=0.6$ & PEL $=3.5$ & 0.6 & 3.5 \\
\hline $\mathrm{Cu}$ & ISQG $=35.7$ & PEL $=197$ & 35.7 & 197 \\
\hline $\mathbf{F e}$ & $\mathrm{LEL}=21,200$ & $\mathrm{SEL}=43,766$ & - & - \\
\hline $\mathbf{P b}$ & $\mathrm{ISQG}=35$ & PEL = 91 & 35.0 & 91.3 \\
\hline $\mathrm{Ni}$ & $\mathrm{LEL}=16$ & $\mathrm{SEL}=75$ & - & - \\
\hline Zn & ISQG $=123$ & PEL $=315$ & 123 & 315 \\
\hline
\end{tabular}

ISQG - interim sediment quality guideline

PEL - probable effects level

LEL - lowest effect level

SEL - severe effect level

SLC - screening level concentration

- - not available

\subsection{The Pennask Creek Watershed}

The Pennask Creek watershed is located to the south of Pennask Lake in the Thompson-

Okanagan region of BC, Canada (Figure 2.3). Pennask Creek is the main drainage course in the watershed, originating at Pennask Mountain to the south and draining generally north into the southwest corner of Pennask Lake. The lake is also fed by other surrounding watersheds, so Pennask Creek is not its sole water source. Both Pennask Creek and Pennask Lake are fishbearing waterways and are therefore protected under Canada's Fisheries Act. 


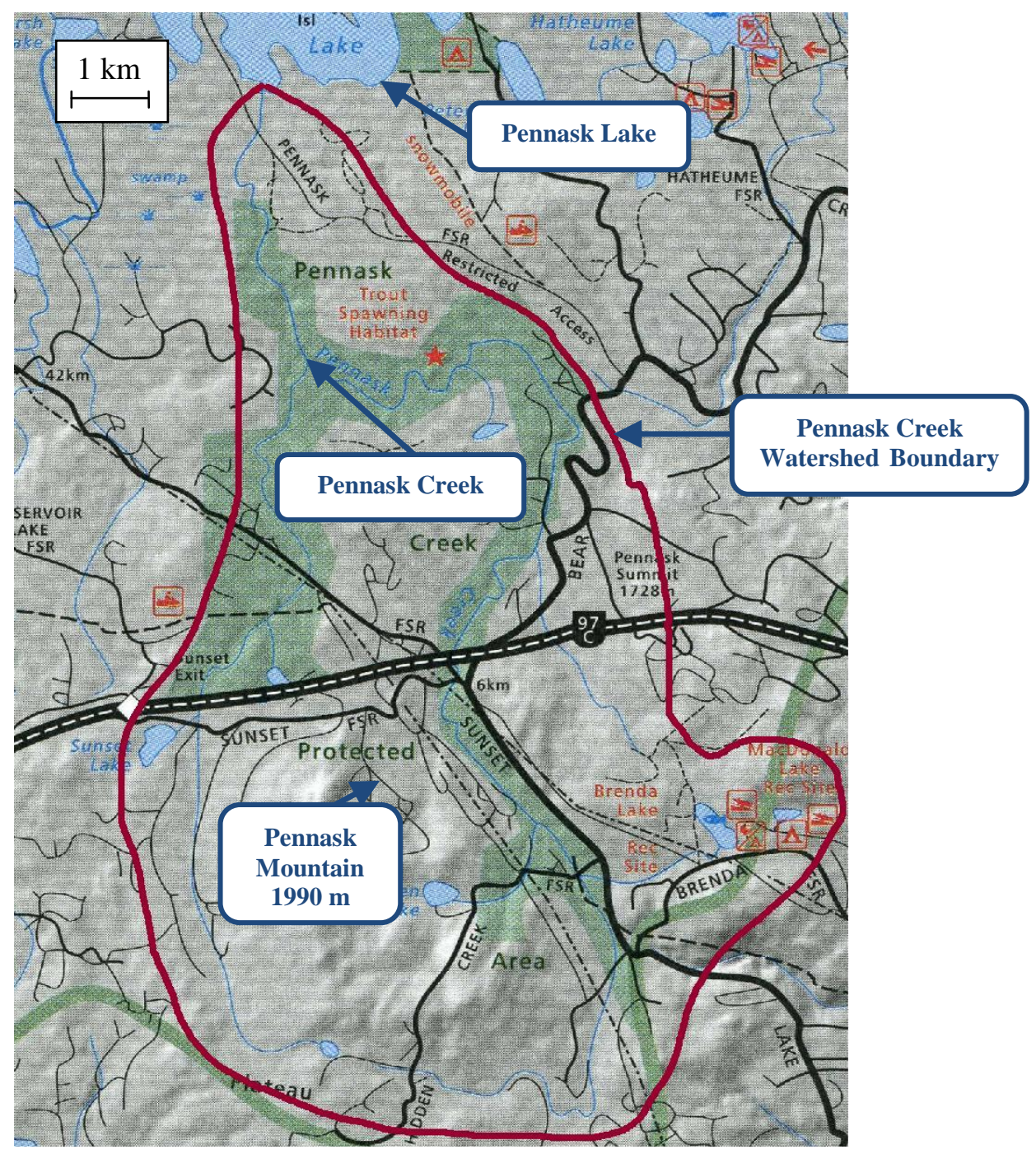

Figure 2.3: Map showing the approximate boundary of the Pennask Creek watershed

As discussed in Chapter 1, construction of Highway 97C through the Pennask Creek watershed resulted in the generation of ARD/ML due to exposure of a highly pyritic rock cut located to the east of Highway Creek (Figure 2.4). The ARD/ML problem was first noted in 1992 (Morin and Hutt 2003). 


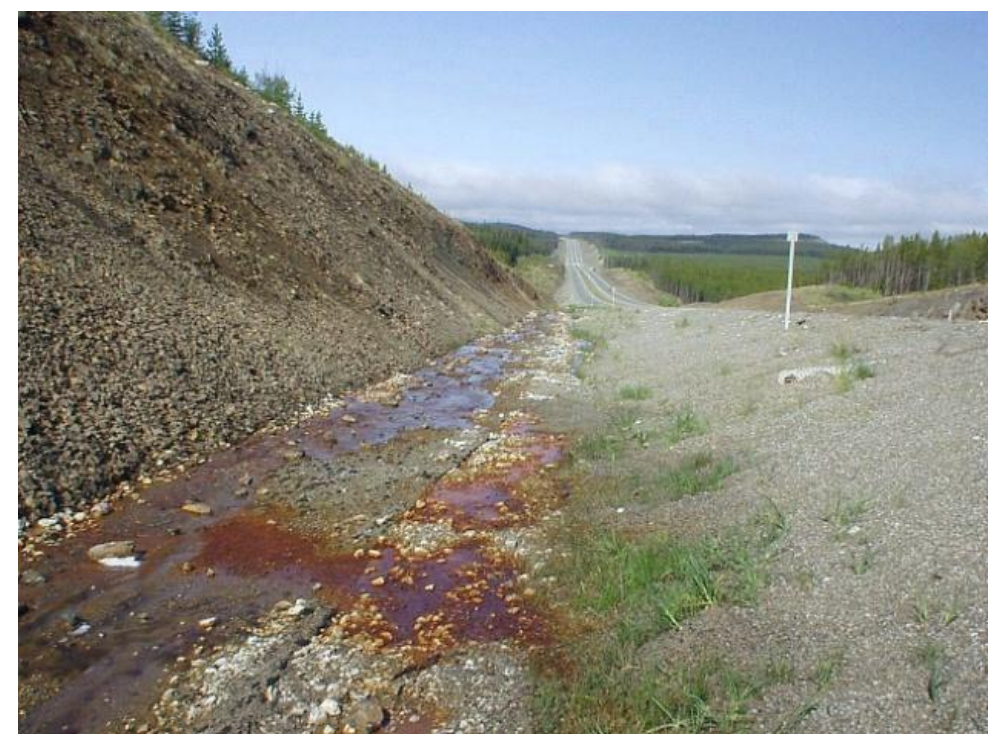

Figure 2.4: Photograph of ARD flowing from rock cut on south side of Highway 97C towards Highway Creek

\subsubsection{Geology and hydrology}

The Pennask Creek watershed is generally underlain by bedrock of the upper Triassic Nicola Group, which is intruded and enclosed to the north, east and south by plutonic rocks of the Early Jurassic Pennask batholith and the Late Jurassic Osprey Lake batholith (Dawson et al. 1988). The former Brenda Mine, a Cu-Mo deposit, is located to the southeast of the watershed. Mineralization is hosted within the zoned and composite quartz diorite "Brenda Stock", which forms part of the Pennask batholith. Principal opaque minerals are chalcopyrite and molybdenite with minor pyrite and magnetite (Dawson et al. 1988). $\mathrm{Cu}$ and Mo production began at the open pit mine in 1970 and ceased in 1990 due to depletion of ore reserves. All water from the mine site is treated onsite and discharged into MacDonald Creek which eventually flows eastward into Okanagan Lake (Xstrata Copper, no date). There is no surface water flow into the Pennask Creek watershed.

The MINFILE mineral inventory database of the BC Ministry of Energy, Mines and Petroleum Resources (2007) indicates that there are no mines in the Pennask Creek watershed, but there are four mineral showings: two near Pennask Mountain and Hidden Lake in the southern, elevated part of the watershed (PEN 5 -092HNE300 and PEN 8 - 092HNE301) and two near the southeastern watershed boundary (PEN 9 - 092HNE302 and Peachland Creek - 092HNE303). These mineral showings contain iron-bearing materials like pyrite and pyrrhotite, zinc-bearing spalerite, arsenic-bearing arsenopyrite, and lead-bearing galena. This indicates that the 
headwaters of Pennask Creek drain an area containing rock with a known capacity to generate acidity and leach metals (Morin and Hutt 2003). These showings were also associated with limestone, which can neutralize acidity and convey excess alkalinity to drainage water.

TRANS has previously commissioned geological and hydrological studies in the Pennask Creek watershed. These studies indicate that bedrock in the area east of Highway Creek consists of bedded, fine- to medium-grained sedimentary rock consisting of mainly argillaceous siltstone with varying amounts of mudstone and sandstone. Several dykes intrude on the sedimentary rock, ranging from dark grey to green ultra-basic lamprophyre, to light brown to white syenite and felsic rhyolite. The colour variations within the dykes are the result of iron precipitation from groundwater flowing through the adjacent pyrite-rich sediments (Grunenberg and Tomlinson 2001). Morin and Hutt (2003) and Grunenberg and Tomlinson (2001) reported results of laboratory analyses confirming that samples taken in the area of the rock cuts were net acid generating. Golder Associates Ltd. (2009) stated that the potential for acid generation and metal leaching exists on either side of Highway Creek and Highway 97C, as well as from the highway fill over Highway Creek.

Grunenberg and Tomlinson (2001) state that groundwater is expected to flow in a northwesterly direction, towards Pennask Lake, through fractures in the bedrock. Based on data collected by TRANS prior to 2007, it is inferred that shallow groundwater flows from south to north, except near Highway Creek where it flows towards the creek (east and west). Groundwater quality assessments suggest that groundwater on the south side of the highway (upstream) is of better quality than groundwater on the north side (downstream), where the $\mathrm{pH}$ is below 4 and dissolved $\mathrm{Al}$ and Zn exceed Environment Canada groundwater quality criteria (Golder Associates Ltd. 2009).

\subsubsection{Vegetation and wildlife}

The Pennask Creek watershed is situated in the Southern Thompson Upland Ecosection and contains portions of two biogeoclimatic zones: Montane Spruce (very dry/cool) and Montane Spruce (dry/mild). The dominant tree species in the area include Alpine Fir (Abies lasiocarpa), Engelmann Spruce (Picea engelmannii), and Lodgepole Pine (Pinus contorta). The Pennask Creek watershed and Pennask Lake support a provincially significant wild rainbow trout population, with approximately 15,000 to 25,000 wild rainbow trout moving up into Pennask Creek from the lake to spawn each year. Annually, approximately two million eggs are removed 
from $10 \%$ of the spawning female rainbow trout along with milt from male rainbow trout, and are transported to a nearby fish hatchery to be fertilized, hatched and reared. These fish, once sufficiently developed, are then used to stock lakes through the southern interior of BC (BCMWLAP 2003).

\subsubsection{Land use}

Much of the Pennask Creek watershed is incorporated into the BC Parks Pennask Creek Protected Area, which covers approximately 1,245 hectares. The Protected Area includes the majority of both branches of Pennask Creek to a distance of between 50 and 400 metres to either side of midstream. This Protected Area was created in 2001 to protect the critical spawning and rearing habitat of the resident wild rainbow trout population. Pennask Creek and its tributaries are closed to recreational fishing. Access to the watershed is via forest service roads, old logging roads, and skid tracks. Land use within the Protected Area includes BC Hydro utility corridors, grazing tenures, and trapping. Adjacent to the Protected Area, forestry and extensive cattle grazing occur (BCMWLAP 2003).

\subsubsection{ARD/ML history}

Several studies have been carried out regarding the ARD/ML problem in the Pennask Creek watershed. The BC Ministry of Transportation and Infrastructure is committed to supporting further research and an ongoing monitoring program. Table 2.3 outlines many of the studies that have been conducted to date. Regular monitoring of the water quality and benthic invertebrate populations has been carried out since 1999. Results indicate that Highway Creek is severely impacted by ARD/ML from Highway 97C, resulting in elevated metals concentrations and greatly diminished benthic invertebrate abundance and diversity (BWP 1999-2009, Golder Associates Ltd. 2008, 2009). Water quality monitoring has revealed a general trend of decreasing metal concentrations in both Highway Creek and Pennask Creek over time (BWP 2000-2009). However, metal concentrations, including $\mathrm{Al}, \mathrm{Cu}$ and $\mathrm{Zn}$, continue to be present in Highway Creek at concentrations that exceed the BC Water Quality Guidelines for the Protection of Aquatic Life (BWP 2009, Golder Associates Ltd. 2009). 
Table 2.3: Studies examining ARD/ML in the Pennask Creek watershed

\begin{tabular}{|c|c|c|}
\hline Report & Medium Studied & Relevant Findings \\
\hline $\begin{array}{l}\text { BWP } \\
\text { Consulting } \\
1999\end{array}$ & benthic invertebrates & $\begin{array}{l}\text { Highway Cr.: yielded very few invertebrates upstream and } \\
\text { downstream of ARD source (perhaps due to poor site choice); } \\
\text { Pennask Cr.: upstream of confluence with Highway Cr. yielded a } \\
\text { much higher number of invertebrates than all downstream sites }\end{array}$ \\
\hline $\begin{array}{l}\text { BWP } \\
\text { Consulting } \\
2000\end{array}$ & $\begin{array}{l}\text { surface water, } \\
\text { benthic invertebrates }\end{array}$ & $\begin{array}{l}\text { ARD source: } \mathrm{pH}=3.1 \text {, exceptionally high metal concentrations; } \\
\text { Highway Cr.: metals concentrations increase by } 200-33,200 \% \\
\text { downstream of ARD source; upstream of ARD source yielded a } \\
\text { more plentiful and diverse invertebrate community than } \\
\text { downstream; } \\
\text { Pennask Cr.: water quality improved greatly } 500 \mathrm{~m} \text { downstream of } \\
\text { confluence; upstream of confluence yielded a more plentiful and } \\
\text { diverse invertebrate community than downstream }\end{array}$ \\
\hline $\begin{array}{l}\text { BWP } \\
\text { Consulting } \\
2001\end{array}$ & $\begin{array}{l}\text { surface water, } \\
\text { benthic invertebrates }\end{array}$ & $\begin{array}{l}\text { results generally follow trends as for BWP ( } 2000) \text {; } \\
\text { Pennask Cr.: by } \sim 13 \mathrm{~km} \text { downstream of confluence, invertebrate } \\
\text { numbers/diversity and metal concentrations return to upstream } \\
\text { levels }\end{array}$ \\
\hline $\begin{array}{l}\text { Grunenberg } \\
\text { and } \\
\text { Tomlinson } \\
2001\end{array}$ & $\begin{array}{l}\text { rock, } \\
\text { groundwater, } \\
\text { surface water }\end{array}$ & $\begin{array}{l}\text { bedded, fine- to medium-grained sedimentary with igneous } \\
\text { intrusions and metamorphism, topped with glacial till; pyrite } \\
\text { common }(1 \text { to }>10 \%) \text {; rock samples were net acid generating; } \\
\text { groundwater is expected to flow in NW direction; near-neutral } \\
\text { pH; plume of high sulphate and metal concentration groundwater } \\
\text { moving towards Highway Cr.; surface water chemistry similar to } \\
\text { previous studies }\end{array}$ \\
\hline $\begin{array}{l}\text { BWP } \\
\text { Consulting } \\
2002\end{array}$ & $\begin{array}{l}\text { surface water, } \\
\text { benthic invertebrates }\end{array}$ & $\begin{array}{l}\text { surface water: } \mathrm{Al}, \mathrm{Cu}, \mathrm{Mn}, \mathrm{Ni}, \mathrm{Zn} \text { concentrations generally lower } \\
\text { than previous years; } \\
\text { benthic invertebrates: generally follow trends for previous years, } \\
\text { except for a } 50 \% \text { decrease (from 2001) in number collected at site } \\
\text { in Pennask Cr. } 500 \mathrm{~m} \text { downstream of confluence with Highway } \\
\mathrm{Cr} \text {. }\end{array}$ \\
\hline $\begin{array}{l}\text { BWP } \\
\text { Consulting } \\
2003\end{array}$ & $\begin{array}{l}\text { surface water, } \\
\text { benthic } \\
\text { invertebrates, } \\
\text { stream sediments }\end{array}$ & $\begin{array}{l}\text { surface water and benthic invertebrates: generally follow trends } \\
\text { from previous years; } \\
\text { sediments: no clear pattern of metal concentrations in Highway } \\
\text { Cr. (alternately high and low values) }\end{array}$ \\
\hline $\begin{array}{l}\text { Morin and } \\
\text { Hutt } 2003\end{array}$ & $\begin{array}{l}\text { surface water, } \\
\text { surface minerals }\end{array}$ & $\begin{array}{l}\text { Highway Cr. } \mathrm{pH} \text { between } 5.7-7, \text { Pennask } \mathrm{Cr} . \mathrm{pH} 6.3-7.7 \\
\text { elements of concern in creek waters are } \mathrm{Al}, \mathrm{Cu}, \mathrm{Mn}, \mathrm{Zn} ; \\
\text { Rock cuts and broken rocks nearby are a source of ARD/ML; }\end{array}$ \\
\hline $\begin{array}{l}\text { BWP } \\
\text { Consulting } \\
2004\end{array}$ & $\begin{array}{l}\text { surface water, } \\
\text { benthic invertebrates }\end{array}$ & $\begin{array}{l}\text { surface water: Highway } \mathrm{Cr} \text {. metal concentration followed trends } \\
\text { from previous years; Pennask } \mathrm{Cr} \text {. concentrations of } \mathrm{Cu}, \mathrm{Mn} \text {, and } \\
\mathrm{Ni} \text { were lower than in previous years, } \mathrm{Al} \text { and } \mathrm{Zn} \text { remained similar } \\
\text { benthic invertebrates: generally follow trends from previous years }\end{array}$ \\
\hline $\begin{array}{l}\text { BWP } \\
\text { Consulting } \\
2005\end{array}$ & $\begin{array}{l}\text { surface water, } \\
\text { benthic invertebrates }\end{array}$ & $\begin{array}{l}\text { surface water: similar to previous years with a continuing trend of } \\
\text { decreasing metal concentrations in both creeks; } \\
\text { benthic invertebrates: similar to previous years at all sites }\end{array}$ \\
\hline
\end{tabular}




\begin{tabular}{|c|c|c|}
\hline Report & Medium Studied & Relevant Findings \\
\hline $\begin{array}{l}\text { BWP } \\
\text { Consulting } \\
2006\end{array}$ & $\begin{array}{l}\text { surface water, } \\
\text { benthic invertebrates }\end{array}$ & as for BWP (2005) \\
\hline Li 2006 & surface water & $\begin{array}{l}\text { decreased water quality (lower } \mathrm{pH} \text { and higher metal } \\
\text { concentrations) downstream of ARD source in Highway } \mathrm{Cr} \text {.; } \\
\text { ARD seepage appears to be occurring into Highway Cr. }\end{array}$ \\
\hline $\begin{array}{l}\text { BWP } \\
\text { Consulting } \\
2007\end{array}$ & $\begin{array}{l}\text { surface water, } \\
\text { benthic invertebrates }\end{array}$ & as for BWP (2006) \\
\hline Li 2007 & surface water & $\begin{array}{l}\text { treated drainage flows: water quality improved when system } \\
\text { operated properly; } \\
\text { downstream sites in Highway Cr. had decreased water quality, } \\
\text { possibly due to seepage of ARD }\end{array}$ \\
\hline $\begin{array}{l}\text { BWP } \\
\text { Consulting } \\
2008\end{array}$ & $\begin{array}{l}\text { surface water, } \\
\text { benthic invertebrates }\end{array}$ & as for BWP (2007) \\
\hline $\begin{array}{l}\text { Golder } \\
\text { Associates } \\
\text { Ltd. } 2008\end{array}$ & surface water & $\begin{array}{l}\text { untreated drainage flows: } \mathrm{Al}, \mathrm{Cu}, \mathrm{Zn} \text { above guidelines, } \mathrm{Cd}, \mathrm{Fe} \text {, } \\
\mathrm{Ni}, \mathrm{Tl}, \mathrm{Co}, \mathrm{Mn} \text { of concern treated drainage flows: } \mathrm{Al}, \mathrm{Cu}, \mathrm{Zn} \\
\text { reduced to below guidelines (when operating properly); }\end{array}$ \\
\hline $\begin{array}{l}\text { BWP } \\
\text { Consulting } \\
2009\end{array}$ & $\begin{array}{l}\text { surface water, } \\
\text { benthic invertebrates }\end{array}$ & as for BWP (2008) \\
\hline $\begin{array}{l}\text { Golder } \\
\text { Associates } \\
\text { Ltd. } 2009\end{array}$ & $\begin{array}{l}\text { surface water, } \\
\text { groundwater }\end{array}$ & $\begin{array}{l}\text { metal concentrations in Highway } \mathrm{Cr} \text {. are declining over time; } \\
\text { treated drainage flows: } \mathrm{pH} \text {, metal concentrations meet guidelines; } \\
\text { groundwater: low (4.0) } \mathrm{pH} \text { and } \mathrm{Al}, \mathrm{Zn} \text { concentrations exceed } \\
\text { guidelines upstream of highway; } \\
\text { ARD seepage appears to be occurring into Highway } \mathrm{Cr} \text {. }\end{array}$ \\
\hline
\end{tabular}

TRANS has been actively monitoring and attempting to mitigate environmental impacts from the ARD/ML along Highway 97C for approximately ten years. In 2000, TRANS lined ARD drainage ditches alongside the highway with limestone and constructed settling ponds downstream of the ARD-generating rock cuts (Golder Associates Ltd. 2008). In 2004, TRANS was prosecuted and pled guilty to charges of depositing a deleterious substance into Pennask Creek, under the Canadian Fisheries Act. The penalty imposed included a fine of $\$ 1000$, a payment of \$45,000 to the Environmental Damages Fund, and an order to conduct ongoing monitoring of water quality (Environment Canada 2005). In 2006, TRANS installed a trial ARD/ML treatment system to raise the $\mathrm{pH}$ of the drainage flows and remove metals from the drainage flow. This system consists of two tanks used to store and dispense quicklime and clinoptilolite (a natural zeolite used to adsorb metals) into the drainage stream. Water quality of 
the pre- and post- treatment water has been and continues to be monitored to assess the effectiveness of this trial treatment system. The treated drainage is collected in a settling pond onsite until it is pumped and transported offsite for further treatment. Currently, none of the treated ARD is discharged into the Pennask Creek watershed. 


\section{CHAPTER 3: MATERIALS AND METHODS}

\subsection{Field Methods}

The Pennask Creek watershed is made up of two separate branches (west and east) of Pennask Creek, Highway Creek (a tributary of the east branch), as well as several smaller tributaries. Downstream of the confluence of the west and east branches of Pennask Creek, the water flows into Pennask Lake (shown in Figure 1.1). Highway 97C bisects both branches of Pennask Creek as well as Highway Creek.

To investigate the effect of Highway 97C ARD/ML on the watershed, locations for the collection of water, sediment, and rock samples were chosen along both branches of Pennask Creek, along Highway Creek, and near the outflow of Pennask Creek into Pennask Lake. Samples were collected from both upstream and downstream of the highway in each of the west and east branches of Pennask Creek, as well as Highway Creek. The locations of sampling sites are shown in Figure 3.1. When choosing the sample stations, consideration was also given to the sampling locations used in previous studies conducted by BWP Consulting (1999-2009) to allow for comparison of data.

Water and sediment samples were collected on two separate occasions - July 22-23, 2009 and September 26, 2009. Rock samples were collected only on September 26, 2009. Station P5 was added for September sampling to ascertain the water and sediment quality near the outflow to Pennask Lake. Stations H1-A and H1-B were combined into one sampling station in September (H1) because it was deemed that the water and sediment quality was not significantly different between the two sites. 


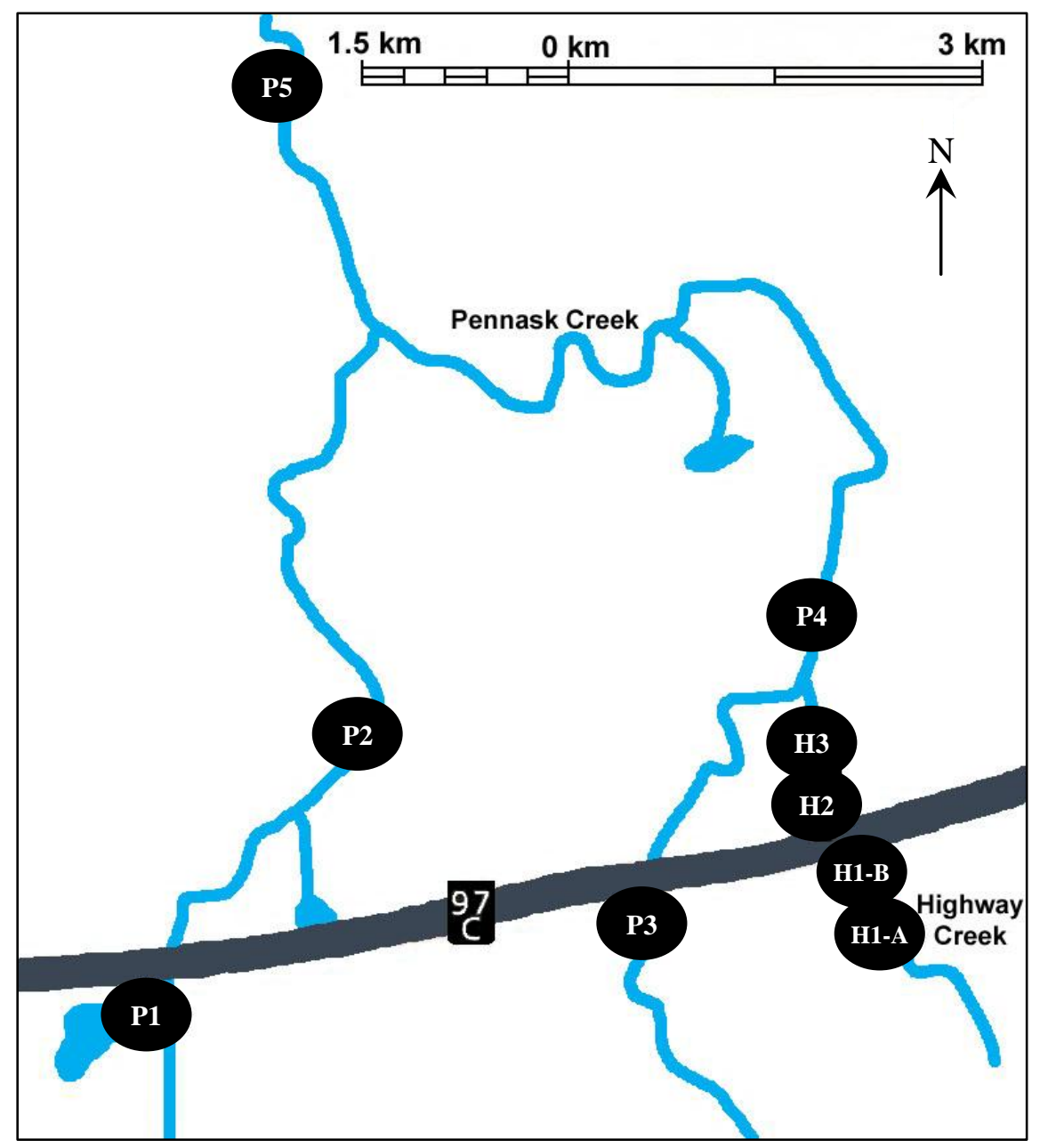

Figure 3.1: Location of water, sediment and rock sampling stations

All field plastic and glassware, along with sampling tools were washed with detergent, rinsed thoroughly with tap water, rinsed three times with $10 \%$ nitric acid $\left(\mathrm{HNO}_{3}\right)$, followed by a tap water rinse, distilled water rinse, and deionized water rinse before use. To prevent crosscontamination between sampling locations in the field, all tools were rinsed thoroughly with deionized water between sites.

\subsubsection{Water sampling}

Temperature, dissolved oxygen, $\mathrm{pH}$, specific conductivity and turbidity were measured in situ. One $3 \mathrm{~L}$ grab sample of water was collected at each station from the top $20 \mathrm{~cm}$ of the stream flow using a wide-mouthed plastic container. $250 \mathrm{~mL}$ of this grab sample was poured into a high-density polyethylene (HDPE) container to be analyzed in the laboratory for alkalinity, sulphate content, $\mathrm{pH}$ and specific conductivity. A further $500 \mathrm{~mL}$ of the grab sample was poured 
into a second $\mathrm{HDPE}$ container and preserved with $\mathrm{HNO}_{3}$ (to $\mathrm{pH}<2$ ), to be analyzed for total metals in the laboratory. A final $500 \mathrm{~mL}$ of the grab sample was filtered into a third HDPE container in the field using a syringe fitted with a filter housing that contained a disposable 0.45 $\mu \mathrm{m}$ membrane filter. After filtering, this sample was preserved with $\mathrm{HNO}_{3}(\mathrm{pH}<2)$ to be analyzed for dissolved metals in the laboratory. Triplicate grab samples were collected at two of the sampling sites to allow for statistical analysis of results and to ensure that representative water samples were taken. One field blank (deionized water) was also prepared for each of the three laboratory analyses according to the above method. All water samples were placed in coolers containing ice for transport to the laboratory at approximately $4^{\circ} \mathrm{C}$. The samples were stored in the laboratory refrigerator at $4^{\circ} \mathrm{C}$ until further processing.

\subsubsection{Sediment sampling}

Three to five surface sediment grab samples per site were collected using a stainless steel spade. These samples were composited in a plastic mixing bowl by stirring with the spade. The composite samples were placed in high wet-strength sealable plastic bags and transported to the laboratory in coolers containing ice at approximately $4{ }^{\circ} \mathrm{C}$. The samples were stored in darkness in the laboratory refrigerator at $4^{\circ} \mathrm{C}$ until further processing. Additional composite sediment samples for toxicological testing were collected at sample stations P1, P4, H1 and H3 in September following the same method.

\subsubsection{Rock sampling}

Two to four rocks of approximately $1 \mathrm{~kg}$ each were collected from each of the nine sampling stations. Rock samples were placed in labelled plastic bags and transported to the laboratory for analysis.

\subsection{Sample Preparation}

All laboratory plastic and glassware were washed with detergent, rinsed thoroughly with tap water, rinsed three times with $10 \% \mathrm{HNO}_{3}$, followed by a tap water rinse, distilled water rinse, and deionized water rinse before use. To prevent cross-contamination, all plastic and glassware was thoroughly rinsed with tap water and deionized water between handling of different samples. 


\subsubsection{Water samples}

In the laboratory, the three (unpreserved, preserved, filtered/preserved) water samples from each sampling station, as well as the field blank, were subjected to various determinations as outlined in Table 3.1.

Table 3.1: Preparation and analysis of water samples

\begin{tabular}{|c|l|l|}
\hline $\begin{array}{c}\text { Sub-Sample } \\
\text { Unpreserved } \\
\text { Analysis }\end{array}$ & $\mathrm{pH}$ & $\mathrm{pH}$ of room temperature samples determined using $\mathrm{pH}$ meter \\
\hline $\begin{array}{c}\text { Unpreserved } \\
\text { B }\end{array}$ & $\begin{array}{l}\text { Specific } \\
\text { Conductivity }\end{array}$ & $\begin{array}{l}\text { Specific conductivity of room temperature samples determined using } \\
\text { conductivity meter, temperature-corrected to } 25^{\circ} \mathrm{C}\end{array}$ \\
\hline $\begin{array}{c}\text { Unpreserved } \\
\text { C }\end{array}$ & Alkalinity & $\begin{array}{l}\text { Total alkalinity of room temperature samples determined by } \\
\text { potentiometric titration to endpoint of } \mathrm{pH} 4.5 \pm 0.2 \text { using } 0.02 \mathrm{~N} \\
\mathrm{H}_{2} \mathrm{SO}_{4} \text { and } \mathrm{pH} \text { meter }\end{array}$ \\
\hline $\begin{array}{c}\text { Unpreserved } \\
\text { D }\end{array}$ & Sulphate Content & Automated barium chloride turbidimetric sulphate determination \\
\hline $\begin{array}{c}\text { Preserved } \\
\text { Filtered \& } \\
\text { Preserved }\end{array}$ & $\begin{array}{l}\text { Total Metals } \\
\text { Content }\end{array}$ & $\begin{array}{l}\text { Samples digested on hotplate with } \mathrm{HNO}_{3} \text {, concentrated 10x, } \\
\text { analyzed for total metals with ICP-OES }\end{array}$ \\
\hline
\end{tabular}

\subsubsection{Sediment samples}

In the laboratory, chilled sediment samples were removed from the refrigerator and air-dried at room temperature. The air-dried samples were passed through a $2 \mathrm{~mm}$ stainless steel sieve, disaggregated using a mortar and pestle, and then passed through a $63 \mu \mathrm{m}$ stainless steel sieve. Material passing through both sieves ( $<63 \mu \mathrm{m}$ fraction) was stored in acid-washed HDPE plastic containers until further processing. Sub-samples of this material were then taken for various determinations as outlined in Table 3.2. A certified reference material, MESS-3, from the National Research Council of Canada (2000), was also analyzed for total organic carbon and metals to determine the accuracy of the methods used. 
Table 3.2: Preparation and analysis of sediment samples

\begin{tabular}{|c|c|c|}
\hline Sub-Sample & Analysis & Preparation \\
\hline $\mathbf{A}$ & $\mathrm{pH}$ & $\begin{array}{l}\text { 1:1 (whole, wet sediment:deionized water) mixed in end- } \\
\text { over-end shaker for } 30 \mathrm{~min} \text {, allowed to settle, determined } \mathrm{pH} \\
\text { with } \mathrm{pH} \text { meter }\end{array}$ \\
\hline $\mathbf{B}$ & Loss on Ignition (LOI) & Heated in furnace at $550^{\circ} \mathrm{C}$ for $1 \mathrm{~h}$ \\
\hline $\mathbf{C}$ & $\begin{array}{l}\text { Total Organic Carbon } \\
\text { (TOC) }\end{array}$ & $\begin{array}{l}\text { Automated high temperature combustion method to } \\
\text { determine non-purgable organic carbon content }\end{array}$ \\
\hline $\mathbf{D}$ & $\begin{array}{l}\text { Strong Acid Leachable } \\
\text { Metals (SALM) }\end{array}$ & $\begin{array}{l}\text { Digested with nitric acid and hydrochloric acid at } 95^{\circ} \mathrm{C} \text { for } \\
2 \mathrm{~h} \text { and analyzed for total metals with ICP-OES }\end{array}$ \\
\hline $\mathbf{E}$ & $\begin{array}{l}\text { Weak Acid Extractable } \\
\text { Metals (WAEM) }\end{array}$ & $\begin{array}{l}\text { Digested with } 0.5 \mathrm{M} \mathrm{HCl} \text { at room temperature overnight and } \\
\text { analyzed for extractable metals with ICP-OES }\end{array}$ \\
\hline
\end{tabular}

The additional sediment samples for toxicity testing were analyzed within two weeks of collection, as recommended by Environment Canada (2002). For each sample, particles larger than $2 \mathrm{~mm}$ were removed using gloved hands, samples were mixed thoroughly to homogenize using a stainless steel spatula, and then sub-sampled into seven small HDPE containers with no air space and stored at $4^{\circ} \mathrm{C}$ until analysis.

\subsubsection{Rock samples}

In the laboratory, each of the eighteen rock samples was rinsed thoroughly with tap water to remove dirt and debris then allowed to air-dry. The samples were broken using a $5 \mathrm{lb}$ sledge hammer to obtain gravel-sized pieces for further processing. These pieces were then pulverized using a Herzog HSM100 in the University of British Columbia (UBC) Department of Earth and Ocean Science. A subsample of approximately $50 \mathrm{~g}$ was placed into a tungsten-carbide sample pot, which was placed into the pulverizer for three minutes. This pulverized sample was then split and placed into two separate Whirl-Pak plastic bags and stored until analysis.

\subsection{Analytical Techniques - Water}

\subsection{1 pH}

The $\mathrm{pH}$ of water samples was measured both in the field and in the laboratory for confirmation of values. Field $\mathrm{pH}$ was determined using a portable Oakton $\mathrm{pH} /{ }^{\circ} \mathrm{C}$ meter (calibrated with $\mathrm{pH} 4$, 7, and 10 buffer solutions as appropriate) directly in the stream in an area of moving water. Upon return to the laboratory, $\mathrm{pH}$ of the unpreserved water sample was determined using a calibrated Beckman $\phi 44 \mathrm{pH}$ meter. 


\subsubsection{Specific conductivity}

The specific conductivity of water samples was measured both in the field and in the laboratory for confirmation of values. Specific conductivity in the field was determined using a portable Oakton TDS/Conductivity $/{ }^{\circ} \mathrm{C}$ meter directly in the stream in an area of moving water. The meter was calibrated using a solution of $0.01 \mathrm{M}$ potassium chloride $(\mathrm{KCl})$. In the laboratory, conductivity was determined and temperature corrected to $25^{\circ} \mathrm{C}$ using a Radiometer Copenhagen Conductivity Meter (CDM3), which was calibrated with a solution of $0.01 \mathrm{M} \mathrm{KCl}$.

\subsubsection{Temperature}

The stream water temperature was determined in the field by placing a probe connected to a temperature/dissolved oxygen meter (YSI Model 58) directly into the stream channel.

\subsubsection{Dissolved oxygen}

Dissolved oxygen was determined in the field in the same manner as temperature, above. The dissolved oxygen meter (YSI Model 58) was calibrated at each sampling location using the air saturation method.

\subsubsection{Turbidity}

Turbidity was determined in the field using a grab sample of water from the stream analyzed with a Hach $2100 \mathrm{P}$ portable turbidimeter, calibrated daily.

\subsubsection{Alkalinity}

The total alkalinity of the water samples was determined in the laboratory by potentiometric titration of an unpreserved $100 \mathrm{~mL}$ room temperature sub-sample with $0.02 \mathrm{~N}$ sulphuric acid $\left(\mathrm{H}_{2} \mathrm{SO}_{4}\right)$, according to Method 2320, as described by APHA et al. (2005). The $\mathrm{H}_{2} \mathrm{SO}_{4}$ was added to the sample from a burette until the $\mathrm{pH}$ reached $4.5 \pm 0.2$. The volume added and the exact $\mathrm{pH}$ were recorded. Additional titrant was added to reduce the $\mathrm{pH}$ exactly $0.30 \mathrm{pH}$ units and the volume was recorded again. Total alkalinity $\left(\mathrm{mg} \mathrm{CaCO}_{3} / \mathrm{L}\right)$ was calculated using the following formula:

$$
\text { Total Alkalinity }=\frac{(2 B-C) \times N \times 50000}{A}
$$

where:

$$
\begin{gathered}
A=\text { volume of sample }(m L), \\
B=\text { volume of titrant }(m L) \text { added to } 1^{\text {st }} \text { recorded } p H,
\end{gathered}
$$




\subsubsection{Sulphate}

The sulphate $\left(\mathrm{SO}_{4}{ }^{2-}\right)$ content of the water samples was determined using the automated barium chloride turbidimetric technique, modified from Method 4500(E), as described by APHA et al. (2005). In this method, the sulphate is precipitated with acidified barium chloride and then scatters light at $420 \mathrm{~nm}$ to produce a signal which is interpreted by the Lachat QuickChem analyzer.

\subsubsection{Metals}

\subsubsection{Total metals digestion}

The field-preserved water samples were digested on a hotplate with $\mathrm{HNO}_{3}$, as described in Method 3030E (APHA et al., 2005). Samples were also concentrated by evaporation (ten times) during the digestion process. Digested, concentrated samples were stored in HDPE bottles at $4^{\circ} \mathrm{C}$ until analysis.

\subsubsection{Dissolved metals}

The field-filtered and preserved water samples were concentrated by evaporation (ten times) and stored in HDPE bottles at $4^{\circ} \mathrm{C}$ until analysis.

\subsubsection{Metals detection}

Eighteen metals were detected using inductively coupled plasma - optical emission spectrometry (ICP-OES) (Table 3.3). Calibration standards were made up in the same background matrix as the samples being analyzed to minimize any discrepancies due to matrix interference. The precision and accuracy of the method was determined by analyzing triplicate grab samples from two sites, a field blank, as well as analyzing a laboratory-made reference standard with known metal concentrations. All samples were analyzed using ICP-OES (Perkin Elmer Optima 7300DV) in the UBC Environmental Engineering Laboratory. The July total metals samples were also analyzed using a Varian 725-ES ICP-OES instrument in the UBC Department of Earth and Ocean Sciences to check for consistency. Europium (10 ppm in $2 \% \mathrm{HNO}_{3}$ ) was used as an internal standard during analysis. 
Table 3.3: List of metals analyzed and associated ICP-OES detection limits for water samples

\begin{tabular}{|c|c|c|c|}
\hline Metal & $\begin{array}{c}\text { Detection Limit } \\
(\mathrm{mg} / \mathrm{L})\end{array}$ & Metal & $\begin{array}{c}\text { Detection Limit } \\
(\mathrm{mg} / \mathrm{L})\end{array}$ \\
\hline Aluminum (Al) & 0.02 & Iron $(\mathrm{Fe})$ & 0.01 \\
\hline Arsenic (As) & 0.02 & Lead $(\mathrm{Pb})$ & 0.02 \\
\hline Barium $(\mathbf{B a})$ & 0.003 & Magnesium (Mg) & 0.001 \\
\hline Beryllium (Be) & 0.001 & Manganese (Mn) & 0.001 \\
\hline Boron $($ B) & 0.02 & Molybdenum (Mo) & 0.01 \\
\hline Cadmium (Cd) & 0.001 & Nickel (Ni) & 0.005 \\
\hline Calcium (Ca) & 0.001 & Selenium (Se) & 0.05 \\
\hline Cobalt (Co) & 0.005 & Thallium (TI) & 0.05 \\
\hline Copper $(\mathbf{C u})$ & 0.005 & Zinc (Zn) & 0.01 \\
\hline
\end{tabular}

\subsubsection{Hardness}

The hardness of the water samples (mg equivalent $\mathrm{CaCO}_{3} / \mathrm{L}$ ) was calculated from $\mathrm{Ca}$ and $\mathrm{Mg}$ concentrations as determined by ICP-OES analysis, according to the formula below (APHA et al. 2005):

$$
\text { Hardness }(m g \text { equiv.CaCO } 3 / L)=2.497[\mathrm{Ca}(\mathrm{mg} / \mathrm{L})]+4.118[\mathrm{Mg}(\mathrm{mg} / \mathrm{L})]
$$

\subsection{Analytical Techniques - Sediments}

\subsection{1 pH}

The $\mathrm{pH}$ of sediment samples were determined using wet, whole sediments (as delivered to the laboratory), within 7 days of sample collection according to the method specified in the BC Environmental Laboratory Manual (Horvath, 2009). Duplicate subsamples from each sampling site were placed in a $50 \mathrm{~mL}$ plastic centrifuge tube with a 1:1 sediment:deionized water mixture, along with duplicate deionized water blanks. The centrifuge tubes were capped tightly and placed on an end-over-end shaker for $30 \pm 5 \mathrm{~min}$. at room temperature, at approximately $30 \mathrm{rpm}$. Samples were then allowed to settle for $1 \mathrm{~h}$ before $\mathrm{pH}$ determination using an electrometric $\mathrm{pH}$ meter that was calibrated with $\mathrm{pH} 4$ and 7 buffers.

\subsubsection{Total organic carbon}

The total organic carbon (TOC) content of the dried $<63 \mu \mathrm{m}$ sediment samples was determined using the high temperature combustion method (5130B), as described by APHA et al. (2005). For each sediment sample, approximately $50 \mathrm{mg}$ was mixed in a plastic beaker with $50 \mathrm{~mL}$ of Milli-Q (carbon-free) water with a magnetic stirrer for ten minutes to homogenize the sample. 
Three subsamples (to check for homogeneity) were then taken with a $5 \mathrm{~mL}$ pipette while stirring continued, and placed into the analysis vials. One drop of $10 \% \mathrm{HCl}$ was added to each vial to lower the $\mathrm{pH}$ to approximately 2 and to allow for purging of the inorganic carbon. The nonpurgable organic carbon content of the samples was determined using a Lachat IL 550 TOC-TN analyzer. A reference sediment (MESS-3) as well as a known laboratory check standard were also analyzed to determine the accuracy and precision of the analysis.

\subsubsection{Loss on ignition}

Loss on ignition (volatile solids) was determined to provide a measure of the organic matter content of the sediment samples, according to the method outlined by APHA et al. (2005). The precision and accuracy of this method was determined by performing duplicate analysis of samples and analyzing a certified reference material (MESS-3).

Aluminum dishes were prepared by firing at $550^{\circ} \mathrm{C}$ for $1 \mathrm{~h}$ before use. The empty, prepared dishes were weighed before being filled with $2.5 \pm 0.1 \mathrm{~g}$ of air-dried $(<63 \mu \mathrm{m})$ sediment subsamples. The mass of dished and sediment was recorded with an electronic balance accurate to $0.01 \mathrm{~g}$. The sediment filled dishes were placed in an oven to dry at $105^{\circ} \mathrm{C}$ until no further weight change was observed. The weight of the dish plus the oven-dried sediment was recorded. Samples were then placed in a muffle furnace and heated at $550^{\circ} \mathrm{C}$ for one hour to burn off the organic material. Samples were weighed and the loss on ignition (volatile solids) was calculated on the basis of the sample dry weight using the formula below:

$$
\% \text { volatile solids }=\frac{(\text { mass of dish }+ \text { dried sediment })-(\text { mass of dish }+ \text { ignited sediment })}{(\text { mass of dish }+ \text { dried sediment })-(\text { mass of dish })} \times 100
$$

\subsubsection{Metals}

\subsubsection{Strong acid leachable metals digestion}

Air-dried $<63 \mu \mathrm{m}$ sediments were digested using a block digester with $\mathrm{HNO}_{3}$ and hydrochloric acid ( $\mathrm{HCl})$, as described in the "Strong Acid Leachable Metals in Soil - Prescriptive" method of the BC Environmental Laboratory Manual (Horvath, 2009). The precision and accuracy of the method was determined by performing triplicate digestion and analysis of each sediment sample, as well as analyzing a method blank and digested certified reference material (MESS-3).

$1.0 \pm 0.1 \mathrm{~g}$ (dry weight) of sediment was placed into a digestion vessel. $5 \pm 0.2 \mathrm{~mL}$ of deionized water, $2.5 \pm 0.2 \mathrm{~mL}$ of concentrated $\mathrm{HNO}_{3}$, and $2.5 \pm 0.2 \mathrm{~mL}$ of concentrated $\mathrm{HCl}$ were added to 
each vessel and swirled to mix. The digestion vessels containing samples, water and acids were left to digest for at least $1 \mathrm{~h}$ at room temperature. Samples were then placed in a block digester for $2 \mathrm{~h} \pm 15 \mathrm{~min}$ with a sample extract temperature of $95 \pm 5^{\circ} \mathrm{C}$. Samples were then cooled and diluted to $50 \mathrm{~mL}$ with deionized water, filtered (Whatman no. 54), and stored in acid-washed HDPE bottles at $4{ }^{\circ} \mathrm{C}$ until analysis.

\subsubsection{Weak acid extractable metals digestion}

Air-dried $<63 \mu \mathrm{m}$ sediments were digested at room temperature using $0.05 \mathrm{M} \mathrm{HCl}$, according to the method used by Li et al. (2009). The method precision and accuracy was determined by performing triplicate digestion and analysis of sediment samples, as well as analysis of a method blank and digested certified reference material (MESS 3).

$20 \mathrm{~mL}$ of $0.05 \mathrm{M} \mathrm{HCl}$ was added to a polypropylene centrifuge tube containing $2 \pm 0.1 \mathrm{~g}$ of airdried sediment. The tubes were capped and placed in an end-over-end shaker $(\approx 30 \mathrm{rpm})$ at room temperature overnight. After settling, the samples were filtered (Whatman no. 541) and the digest was made up to $40 \mathrm{~mL}$ with deionized water. The samples were stored in acid-washed HDPE bottles at $4{ }^{\circ} \mathrm{C}$ until analysis.

\subsubsection{Metals detection}

Eighteen metals were detected using ICP-OES (Table 3.4). All sediment samples were analyzed using a Perkin Elmer Optima 7300DV in the UBC Environmental Engineering Laboratory, as described in section 3.3.8.2.

Table 3.4: List of metals analyzed and associated ICP-OES detection limits for sediment samples

\begin{tabular}{|c|c|c|c|}
\hline Metal & $\begin{array}{l}\text { Detection Limit } \\
(\mathrm{mg} / \mathrm{kg}, \mathrm{dw})\end{array}$ & Metal & $\begin{array}{l}\text { Detection Limit } \\
(\mathrm{mg} / \mathrm{kg}, \mathrm{dw})\end{array}$ \\
\hline Aluminum (Al) & 1 & Iron (Fe) & 0.5 \\
\hline Arsenic (As) & 1 & Lead $(\mathrm{Pb})$ & 0.1 \\
\hline Barium (Ba) & 0.15 & Magnesium (Mg) & 0.05 \\
\hline Beryllium (Be) & 0.05 & Manganese (Mn) & 0.05 \\
\hline Boron $(\mathbf{B})$ & 1 & Molybdenum (Mo) & 0.5 \\
\hline Cadmium (Cd) & 0.05 & Nickel (Ni) & 0.25 \\
\hline Calcium (Ca) & 0.05 & Selenium (Se) & 2.5 \\
\hline Cobalt (Co) & 0.25 & Thallium (Tl) & 2.5 \\
\hline$\overline{\text { Copper }(\mathrm{Cu})}$ & 0.25 & Zinc (Zn) & 0.5 \\
\hline
\end{tabular}




\subsection{Analytical Techniques - Rocks}

\subsubsection{Mineralogical composition}

Qualitative X-ray powder diffraction was carried out by the UBC Department of Earth and Ocean Sciences to determine the mineralogical composition of the rock samples. The pulverized rock samples were ground into fine powder with a corundum mortar and smeared on to a glass slide with ethanol. Step-scan X-ray powder-diffraction data were collected over a range 3-80 $2 \theta$ with CoKa radiation on a Bruker D8 Focus Bragg-Brentano diffractometer equipped with an Fe monochromator foil, $0.6 \mathrm{~mm}\left(0.3^{\circ}\right)$ divergence slit, incident- and diffracted-beam Soller slits and a LynxEye detector. The long fine-focus Co X-ray tube was operated at $35 \mathrm{kV}$ and $40 \mathrm{~mA}$, using a take-off angle of $6^{\circ}$.

\subsubsection{Chemical composition}

The major and minor elements present in the rock samples were determined using X-ray fluorescence spectrometry. The analyses were carried out by the UBC Department of Earth and Ocean Sciences, as described by Calvert et al. (1985). Lithium tetraborate glass beads (for major elements) and wax-supported powder briquettes (minor elements) were analyzed on a Philips PW-2400 wavelength-dispersive emission spectrometer, utilizing an Rh target X-ray tube.

\subsubsection{Acid-base accounting}

After completion of mineralogical and chemical composition analyses (see section 4.3), it was decided that acid-base accounting was unnecessary due to the low likelihood of acid-generating potential in the Pennask Creek watershed rock samples.

\subsection{Compilation of Existing Water Quality and Benthic Invertebrate Data}

Water quality and benthic invertebrate monitoring has been conducted on Highway Creek and Pennask Creek by BWP Consulting (2000-2009) to determine the effects of ARD from Highway 97C. Data from these monitoring reports was compiled for use in this study to establish the historical trends in the Pennask Creek watershed.

\subsubsection{Water quality data}

Water quality data from BWP Consulting (2000-2009) was compiled in Microsoft Excel to determine historical trends in water quality of the Pennask Creek watershed. The parameters included in this compilation were: $\mathrm{pH}$, specific conductivity, dissolved $\mathrm{Al}$, and total $\mathrm{Cu}, \mathrm{Mn}, \mathrm{Ni}$ 
and $\mathrm{Zn}$ concentrations. BWP Consulting carried out sampling at several locations throughout the watershed, with four stations matching those sampled in this study. These four locations (E244074, E252577, E244077 and E244082) are equivalent to sites H1, H2, H3 and P4, respectively. Water sampling at site E252577 (H2) was carried out by BWP Consulting beginning in 2003 only, so no data is available for 2000-2002.

In 2000, water samples were collected in October only. In 2001, water samples were collected from June to December. However, only mean values were presented in the report by BWP. In 2002 and 2003, samples were collected ten times each year between June and November, however data was selected from only one sampling period in each month for ease of presentation. In 2004, water sampling was carried out in late August, early and mid-October and mid-November. The data for early October was not included in this study for ease of presentation. In 2005, water sampling was carried out once in each of July, August, September and October, so all data were included in this study. From 2006 to 2009, water samples were collected once per month between May and October, so all data was included. When data was reported as below the analytical detection limit, it was recorded as half the detection limit when compiled for this study.

\subsubsection{Benthic macroinvertebrate data}

Benthic macroinvertebrate sampling is a useful tool for detecting and monitoring changes in stream ecosystems. To determine historical trends in the Pennask Creek watershed, benthic invertebrate data from BWP Consulting (2000-2009) was compiled in Microsoft Excel. The same four sample locations as for water quality data were utilized in this analysis. A fifth site, E244083, located near the fish hatchery along Pennask Creek, was added to identify trends at a considerable distance from Highway Creek, such as at sample P5 in this study. This site is upstream from the sample site P5; however, it has been equated to P5 for ease of presentation. Parameters calculated from the data include the abundance of benthic macroinvertebrates, the diversity of benthic invertebrates (total number of taxa), the diversity of Ephemeroptera, Plecoptera and Trichoptera (EPT) organisms, and the relative percentage of EPT organisms present in samples for all years, when possible. From 2000 - 2007, sampled invertebrates were identified to Order or Family level, while in 2008 and 2009, invertebrates from the Orders Ephemeroptera, Plecoptera and Trichoptera were identified to the genus level. The total number of Ephemeroptera (mayflies), Plecoptera (stoneflies), and Trichoptera (caddisflies) taxa could 
therefore be determined for 2008 and 2009. This more detailed identification allows for further interpretation regarding the potential impacts at each site, since these species are considered to be very sensitive to poor water quality conditions.

\subsection{Microtox ${ }^{\mathrm{TM}}$ Solid Phase Toxicity Test}

The Microtox ${ }^{\mathrm{TM}}$ Solid Phase Test (SPT) is used to measure the toxicity of whole sediment to luminescent bacteria Vibrio fischeri. The inhibition of light production by the bacteria is the biological endpoint of this test because it is diminished in the presence of toxicants. The Microtox ${ }^{\mathrm{TM}}$ SPT was conducted according to the Reference Method for Determining the Toxicity of Sediment Using Luminescent Bacteria in a Solid-Phase Test (Environment Canada 2002). Samples analyzed were also subjected to analysis of TOC content (according to the method outlined in 3.4.2), moisture content (by gravimetric analysis), and particle size analysis (by sieving) for particles $>1.0 \mathrm{~mm}$ (percent very coarse grained sand), $>63 \mu \mathrm{m}$ but $<2.0 \mathrm{~mm}$ (percent sand), and $\leq 63 \mu \mathrm{m}$ (percent fines). The certified reference material MESS-3 was used as the positive control sediment, while sediment from sample site P1 was used as the negative control sediment. The Microtox ${ }^{\mathrm{TM}}$ SPT involves the preparation of a series of concentrations of the sediment sample by serial dilution, their mixing with an inoculum of test organisms ( $V$. fischeri) and incubation for 20 minutes in test tubes held in a water bath at $15 \pm 0.5^{\circ} \mathrm{C}$, the filtration of the tube contents, the stabilization of the filtrate at $15 \pm 0.5^{\circ} \mathrm{C}$ for 10 minutes in a series of glass cuvettes held in wells of a photometer, and the photometric reading of light produced by the bacteria remaining in the filtrate. The statistical endpoint of the test is the $\mathrm{IC}_{50}$, which is the concentration of sample which is estimated to cause $50 \%$ inhibition of light production. To ensure precision and reliability of the results obtained by this test, the positive reference sediment (MESS-3) was analyzed six times; the results were plotted on a warning chart and were examined to ensure that the results fell within \pm 2 SD of each other (Environment Canada 2002).

\subsection{Statistical Analysis}

Statistical analyses were conducted with S-Plus 8.0 (Insightful Corp. 2007). Censored data (data below analytical detection limits) were replaced with the value of half the detection limit for statistical analyses. 
To test for a difference between July and September samples, data was first tested for normality of distribution using the Kolmogorov-Smirov Goodness of Fit Test. Since the data did not meet the assumption of normality, and due to the small number of samples collected at each site, comparisons of water and sediment chemistry between the July and September samples were conducted using the Wilcoxon Signed-Rank test (also known as the Wilcoxon Matched Pairs test), arranged as paired observations by sample site. The Wilcoxon Signed-Rank test is a nonparametric test that is used to test the median difference in paired data (similar to the parametric paired $t$-test). July and September samples were considered to differ significantly if the $\mathrm{p}$-value was small $(\leq 0.05)$. Field measured $\mathrm{pH}$ and conductivity values were used for statistical analysis of water samples instead of laboratory measured values. For July water samples, the mean of H1-A and H1-B was used as the value for H1. For sediment samples, mean values for three sub-samples were used in statistical analysis. Since site P5 was not sampled in July, it was not included in this analysis. Metals considered for water sample statistical analysis included: $\mathrm{Al}, \mathrm{Cu}, \mathrm{Fe}, \mathrm{Mg}, \mathrm{Mn}, \mathrm{Ni}$, and $\mathrm{Zn}$. Metals considered for sediment sample statistical analysis included: $\mathrm{Al}, \mathrm{As}, \mathrm{Co}, \mathrm{Cu}, \mathrm{Fe}, \mathrm{Mg}, \mathrm{Mn}, \mathrm{Ni}, \mathrm{Pb}$, and $\mathrm{Zn}$. These metals were detected in both total and dissolved samples for water and/or both total and extractable samples for sediment. 


\section{CHAPTER 4: RESULTS}

\subsection{Water Quality}

Water quality parameters were compared to BC and CCME Water Quality Guidelines for the Protection of Aquatic Life (BCMOE 2006, CCME 2007) where applicable. Complete data tables are found in Appendix A.

\subsubsection{General chemistry}

General water chemistry results for July and September samples are provided in Tables A1 and A2 of Appendix A.

The field measured pH values ranged from 6.3 to 7.2 in July and 6.2 to 7.1 in September. In both July and September, the lowest $\mathrm{pH}$ value occurred in Highway Creek, downstream of Highway 97C. Laboratory $\mathrm{pH}$ measurements taken within 5 days of sample collection ranged from 6.8 to 7.4 in July and 6.3 to 7.3 in September. Most sample sites fell within the acceptable pH range (6.5 - 9.0) according to both BC and CCME guidelines, with only sites H2 (July and September) and H3 (September only) showing $\mathrm{pH}$ values $<6.5$.

Specific conductivity $\left(25^{\circ} \mathrm{C}\right)$ field measurements ranged from 38.0 to $103.4 \mu \mathrm{S} / \mathrm{cm}$ in July and 54.0 to $304.0 \mu \mathrm{S} / \mathrm{cm}$ in September. In both months, the lowest value occurred at site P1, while the highest value was seen at site H3. Laboratory conductivity measurements taken within 5 days of sample collection ranged from 43.6 to 148.7 and 56.6 to $307.7 \mu \mathrm{S} / \mathrm{cm}$ in July and September, respectively.

Water temperature measurements were higher in July than September, perhaps due to ambient air temperature. Highway Creek temperatures ranged from 7.3 to $8.4^{\circ} \mathrm{C}$ in July and 5.5 to $7.1^{\circ} \mathrm{C}$ in September. Pennask Creek temperatures ranged from 11.8 to $14.9^{\circ} \mathrm{C}$ in July and 5.0 to $8.5^{\circ} \mathrm{C}$ in September.

Dissolved oxygen concentrations measured in the field ranged from 8.1 to $10.7 \mathrm{mg} / \mathrm{L}$ in July and 11.0 to $13.5 \mathrm{mg} / \mathrm{L}$ in September. 
Turbidity measurements ranged from 0.4 to 3.2 NTU in July and 0.4 to 5.0 NTU in September. Only sites H2 and H3 had turbidity values > 2.5 NTU, with all other sites measured at $<1.0$ NTU.

Total alkalinity measurements ranged from 23.9 to $49.1 \mathrm{mg} / \mathrm{L}$ as $\mathrm{CaCO}_{3}$ and 8.6 to $71.0 \mathrm{mg} / \mathrm{L}$ as $\mathrm{CaCO}_{3}$ in July and September, respectively. In both months, the lowest alkalinity was found at site H3. Site P5 was sampled in September only and showed the highest alkalinity value of 71.0 $\mathrm{mg} / \mathrm{L}$ as $\mathrm{CaCO}_{3}$. All other values were within a similar range as those in July $(<50 \mathrm{mg} / \mathrm{L}$ as $\mathrm{CaCO}_{3}$ ). Only site $\mathrm{H} 3$ in September is classified as 'highly sensitive to acid inputs', according to the $\mathrm{BC}$ working guideline for alkalinity $\left(<10 \mathrm{mg} / \mathrm{L}\right.$ as $\left.\mathrm{CaCO}_{3}\right)$. All other sites are classified as having a 'low sensitivity to acid inputs' according to the $\mathrm{BC}$ working guideline $(>20 \mathrm{mg} / \mathrm{L}$ as $\left.\mathrm{CaCO}_{3}\right)$.

Hardness concentrations were slightly lower in July than in September, ranging from 17.7 to $62.7 \mathrm{mg} / \mathrm{L}$ as $\mathrm{CaCO}_{3}$ and 21.5 to $88.3 \mathrm{mg} / \mathrm{L}$ as $\mathrm{CaCO}_{3}$ in July and September, respectively. In both months, P1 had the lowest hardness concentration, while H3 had the highest.

Sulphate concentrations ranged from 11.0 to $76.8 \mathrm{mg} / \mathrm{L}$ as $\mathrm{SO}_{4}$ in July and 7.0 to $85.6 \mathrm{mg} / \mathrm{L}$ as $\mathrm{SO}_{4}$ in September. In both months, the lowest and highest sulphate concentrations were found at sites $\mathrm{P} 1$ and $\mathrm{H} 3$, respectively. All sulphate concentrations fall below the $\mathrm{BC}$ maximum guideline value of $100 \mathrm{mg} / \mathrm{L}\left(\mathrm{SO}_{4}\right)$, with only site $\mathrm{H} 3$ exceeding the alert level concentration of $50 \mathrm{mg} / \mathrm{L}$ $\left(\mathrm{SO}_{4}\right)$. 


\subsubsection{Metal concentrations}

Complete results for total and dissolved metal concentration analyses for July and September water samples are provided in Tables A3 to A6 (Appendix A). Metals present above analytical detection limits in one or more water samples include aluminum, barium, boron, cobalt, copper, iron, magnesium, manganese, nickel, and zinc. A summary of results for the detected metals are provided in Tables 4.1 to 4.4. A graphical presentation of relevant metal concentrations in July and September water samples is provided in Figures 4.1 to 4.7 to illustrate the spatial patterns of contamination in the Pennask Creek watershed. July concentrations are shown in regular text, while September concentrations are shown in italics. Site P5 was not sampled in July, while sites H1-A and H1-B were combined during September sampling. 
Table 4.1: Summary of total metal concentrations detected in July water samples (for sites $\mathrm{H} 1-\mathrm{B}$ and $\mathrm{H} 3, \mathrm{n}=3$; data shown as mean $\pm \mathrm{SD}$ )

\begin{tabular}{c|c|r|r|r|r|r|r|r|}
\hline $\begin{array}{c}\text { Metal } \\
(\mathrm{mg} / \mathrm{L})\end{array}$ & \multicolumn{10}{c|}{ H1-A } & \multicolumn{1}{c|}{ H1-B } & \multicolumn{1}{c|}{ H2 } & \multicolumn{1}{c|}{ H3 } & P1 & P2 & P3 & P4 \\
\hline $\mathbf{A l}$ & 0.024 & $0.317 \pm 0.390$ & 0.951 & $0.967 \pm 0.016$ & 0.200 & 0.032 & $<\mathrm{DL}$ & 0.061 \\
\hline $\mathbf{B a}$ & $<\mathrm{DL}$ & $<\mathrm{DL}$ & $<\mathrm{DL}$ & $0.003 \pm 0.000$ & 0.003 & 0.003 & $<\mathrm{DL}$ & $<\mathrm{DL}$ \\
\hline $\mathbf{B}$ & $<\mathrm{DL}$ & $<\mathrm{DL}$ & $<\mathrm{DL}$ & $<\mathrm{DL}$ & $<\mathrm{DL}$ & $<\mathrm{DL}$ & $<\mathrm{DL}$ & $<\mathrm{DL}$ \\
\hline $\mathbf{C o}$ & $<\mathrm{DL}$ & $<\mathrm{DL}$ & 0.004 & $0.006 \pm 0.000$ & $<\mathrm{DL}$ & $<\mathrm{DL}$ & $<\mathrm{DL}$ & $<\mathrm{DL}$ \\
\hline $\mathbf{C u}$ & 0.028 & $0.028 \pm 0.007$ & 0.036 & $0.034 \pm 0.004$ & 0.030 & 0.017 & 0.024 & 0.017 \\
\hline $\mathbf{F e}$ & 0.019 & $0.042 \pm 0.011$ & 0.130 & $0.079 \pm 0.003$ & 0.097 & 0.028 & 0.011 & 0.133 \\
\hline $\mathbf{M g}$ & 1.014 & $1.099 \pm 0.044$ & 2.125 & $3.660 \pm 0.073$ & 1.152 & 1.492 & 0.779 & 1.464 \\
\hline $\mathbf{M n}$ & 0.004 & $0.016 \pm 0.001$ & 0.185 & $0.352 \pm 0.005$ & 0.006 & 0.005 & 0.003 & 0.039 \\
\hline $\mathbf{N i}$ & $<\mathrm{DL}$ & $<\mathrm{DL}$ & $<\mathrm{DL}$ & $0.012 \pm 0.001$ & $<\mathrm{DL}$ & $<\mathrm{DL}$ & $<\mathrm{DL}$ & $<\mathrm{DL}$ \\
\hline $\mathbf{Z n}$ & $<\mathrm{DL}$ & $<\mathrm{DL}$ & 0.222 & $0.383 \pm 0.005$ & $<\mathrm{DL}$ & $<\mathrm{DL}$ & $<\mathrm{DL}$ & $<\mathrm{DL}$ \\
\hline
\end{tabular}

$<\mathrm{DL}-$ below detection limit

shading - value exceeds water quality guideline shown in Table 2.1

Table 4.2: Summary of dissolved metal concentrations detected in July water samples (for sites $\mathrm{H} 1-\mathrm{B}$ and $\mathrm{H} 3, \mathrm{n}=3$; data shown as mean $\pm \mathrm{SD}$ )

\begin{tabular}{|c|r|r|r|r|r|r|r|r|}
\hline $\begin{array}{c}\text { Metal } \\
(\mathrm{mg} / \mathrm{L})\end{array}$ & \multicolumn{10}{c|}{ H1-A } & \multicolumn{1}{c|}{ H1-B } & \multicolumn{1}{c|}{ H2 } & \multicolumn{1}{c|}{ H3 } & P1 & \multicolumn{1}{c|}{ P2 } & P3 & P4 \\
\hline $\mathbf{A l}$ & 0.028 & $0.029 \pm 0.004$ & 0.289 & $1.628 \pm 0.595$ & 0.040 & 0.272 & 0.021 & 1.672 \\
\hline $\mathbf{B a}$ & $<\mathrm{DL}$ & $<\mathrm{DL}$ & $<\mathrm{DL}$ & $0.005 \pm 0.000$ & 0.003 & 0.008 & $<\mathrm{DL}$ & 0.003 \\
\hline $\mathbf{B}$ & 0.048 & $0.031 \pm 0.020$ & 0.002 & $0.017 \pm 0.008$ & $<\mathrm{DL}$ & $<\mathrm{DL}$ & 0.038 & $<\mathrm{DL}$ \\
\hline $\mathbf{C o}$ & $<\mathrm{DL}$ & $<\mathrm{DL}$ & $<\mathrm{DL}$ & $0.006 \pm 0.000$ & $<\mathrm{DL}$ & $<\mathrm{DL}$ & $<\mathrm{DL}$ & $<\mathrm{DL}$ \\
\hline $\mathbf{C u}$ & 0.012 & $0.010 \pm 0.001$ & 0.020 & $0.041 \pm 0.001$ & 0.011 & 0.021 & 0.010 & 0.043 \\
\hline $\mathbf{F e}$ & 0.037 & $0.039 \pm 0.005$ & 0.111 & $0.226 \pm 0.150$ & 0.088 & 0.047 & 0.047 & 0.134 \\
\hline $\mathbf{M g}$ & 1.094 & $1.199 \pm 0.028$ & 2.284 & $4.087 \pm 0.059$ & 1.199 & 1.746 & 0.881 & 1.732 \\
\hline $\mathbf{M n}$ & 0.002 & $0.015 \pm 0.001$ & 0.194 & $0.387 \pm 0.002$ & 0.004 & 0.003 & 0.003 & 0.043 \\
\hline $\mathbf{N i}$ & $<\mathrm{DL}$ & $<\mathrm{DL}$ & $<\mathrm{DL}$ & $0.019 \pm 0.000$ & $<\mathrm{DL}$ & $<\mathrm{DL}$ & $<\mathrm{DL}$ & $<\mathrm{DL}$ \\
\hline $\mathbf{Z n}$ & $<\mathrm{DL}$ & $<\mathrm{DL}$ & 0.242 & $0.456 \pm 0.004$ & $<\mathrm{DL}$ & $<\mathrm{DL}$ & $<\mathrm{DL}$ & $<\mathrm{DL}$ \\
\hline
\end{tabular}

$<\mathrm{DL}-$ below detection limit

shading - value exceeds water quality guideline shown in Table 2.1 
Table 4.3: Summary of total metal concentrations detected in September water samples (for sites $\mathrm{P} 3$ and $\mathrm{P} 4, \mathrm{n}=3$; data shown as mean $\pm \mathrm{SD}$ )

\begin{tabular}{c|c|c|c|r|r|r|r|r|}
\hline \multirow{2}{*}{$\begin{array}{c}\text { Metal } \\
(\mathrm{mg} / \mathrm{L})\end{array}$} & \multicolumn{10}{c|}{ H1 } & \multicolumn{1}{c|}{ H2 } & \multicolumn{1}{c|}{ H3 } & \multicolumn{1}{c|}{ P1 } & \multicolumn{1}{c|}{ P2 } & \multicolumn{1}{c|}{ P3 } & \multicolumn{1}{c|}{ P4 } & P5 \\
\hline $\mathbf{A l}$ & 0.058 & 1.621 & 2.281 & 0.060 & 0.037 & $0.009 \pm 0.002$ & $0.057 \pm 0.000$ & 0.029 \\
\hline $\mathbf{B a}$ & $<\mathrm{DL}$ & 0.001 & 0.006 & 0.002 & 0.008 & $<\mathrm{DL}$ & $0.004 \pm 0.000$ & 0.003 \\
\hline $\mathbf{B}$ & $<\mathrm{DL}$ & $<\mathrm{DL}$ & 0.032 & 0.004 & $<\mathrm{DL}$ & $<\mathrm{DL}$ & $<\mathrm{DL}$ & 0.016 \\
\hline $\mathbf{C o}$ & $<\mathrm{DL}$ & .008 & 0.015 & $<\mathrm{DL}$ & $<\mathrm{DL}$ & $<\mathrm{DL}$ & $<\mathrm{DL}$ & $<\mathrm{DL}$ \\
\hline $\mathbf{C u}$ & $<\mathrm{DL}$ & 0.026 & 0.037 & 0.006 & $<\mathrm{DL}$ & $0.006 \pm 0.001$ & $0.008 \pm 0.003$ & 0.006 \\
\hline $\mathbf{F e}$ & 0.088 & 0.230 & 0.206 & 0.172 & 0.073 & $0.056 \pm 0.012$ & $0.186 \pm 0.004$ & 0.241 \\
\hline $\mathbf{M g}$ & 1.273 & 3.039 & 6.131 & 1.403 & 2.420 & $0.927 \pm 0.014$ & $2.402 \pm 0.008$ & 2.451 \\
\hline $\mathbf{M n}$ & 0.019 & 0.321 & 0.657 & 0.007 & 0.006 & $0.003 \pm 0.000$ & $0.066 \pm 0.000$ & 0.012 \\
\hline $\mathbf{N i}$ & $<\mathrm{DL}$ & 0.005 & 0.051 & $<\mathrm{DL}$ & $<\mathrm{DL}$ & $<\mathrm{DL}$ & $<\mathrm{DL}$ & $<\mathrm{DL}$ \\
\hline $\mathbf{Z n}$ & $<\mathrm{DL}$ & 0.357 & 0.731 & $<\mathrm{DL}$ & $<\mathrm{DL}$ & $<\mathrm{DL}$ & $0.027 \pm 0.001$ & $<\mathrm{DL}$ \\
\hline
\end{tabular}

$<\mathrm{DL}-$ below detection limit

shading - value exceeds water quality guideline shown in Table 2.1

Table 4.4: Summary of dissolved metal concentrations detected in September water samples (for sites P3 and P4, $\mathrm{n}=3$; data shown as mean $\pm \mathrm{SD}$ )

\begin{tabular}{|c|c|c|c|c|c|r|r|r|}
\hline \multirow{2}{*}{$\begin{array}{c}\text { Metal } \\
(\mathrm{mg} / \mathrm{L})\end{array}$} & \multicolumn{10}{c|}{ H1 } & \multicolumn{10}{c|}{ H2 } & H3 & \multicolumn{1}{c|}{ P1 } & \multicolumn{1}{c|}{ P2 } & \multicolumn{1}{c|}{ P3 } & \multicolumn{1}{c|}{ P4 } & P5 \\
\hline $\mathbf{A l}$ & 0.076 & 0.243 & 0.260 & 0.044 & 0.024 & $0.030 \pm 0.007$ & $0.024 \pm 0.001$ & $<\mathrm{DL}$ \\
\hline $\mathbf{B a}$ & $<\mathrm{DL}$ & $<\mathrm{DL}$ & 0.007 & 0.003 & 0.008 & $<\mathrm{DL}$ & $0.004 \pm 0.000$ & 0.004 \\
\hline $\mathbf{B}$ & $<\mathrm{DL}$ & $<\mathrm{DL}$ & $<\mathrm{DL}$ & 0.027 & $<\mathrm{DL}$ & $<\mathrm{DL}$ & $<\mathrm{DL}$ & $<\mathrm{DL}$ \\
\hline $\mathbf{C o}$ & $<\mathrm{DL}$ & $<\mathrm{DL}$ & 0.005 & $<\mathrm{DL}$ & $<\mathrm{DL}$ & $<\mathrm{DL}$ & $<\mathrm{DL}$ & $<\mathrm{DL}$ \\
\hline $\mathbf{C u}$ & 0.005 & 0.017 & 0.025 & 0.005 & $<\mathrm{DL}$ & $0.011 \pm 0.002$ & $0.006 \pm 0.001$ & 0.005 \\
\hline $\mathbf{F e}$ & 0.106 & 0.171 & 0.098 & 0.131 & 0.054 & $0.049 \pm 0.007$ & $0.133 \pm 0.002$ & 0.213 \\
\hline $\mathbf{M g}$ & 1.376 & 3.162 & 6.500 & 1.505 & 2.471 & $1.053 \pm 0.008$ & $2.585 \pm 0.017$ & 2.676 \\
\hline $\mathbf{M n}$ & 0.020 & 0.328 & 0.681 & 0.006 & 0.005 & $0.003 \pm 0.000$ & $0.068 \pm 0.000$ & 0.013 \\
\hline $\mathbf{N i}$ & $<\mathrm{DL}$ & 0.007 & 0.059 & $<\mathrm{DL}$ & $<\mathrm{DL}$ & $<\mathrm{DL}$ & $<\mathrm{DL}$ & $<\mathrm{DL}$ \\
\hline $\mathbf{Z n}$ & $<\mathrm{DL}$ & 0.383 & 0.795 & $<\mathrm{DL}$ & $<\mathrm{DL}$ & $<\mathrm{DL}$ & $0.034 \pm 0.000$ & $<\mathrm{DL}$ \\
\hline
\end{tabular}

$<\mathrm{DL}-$ below detection limit shading - value exceeds water quality guideline shown in Table 2.1 


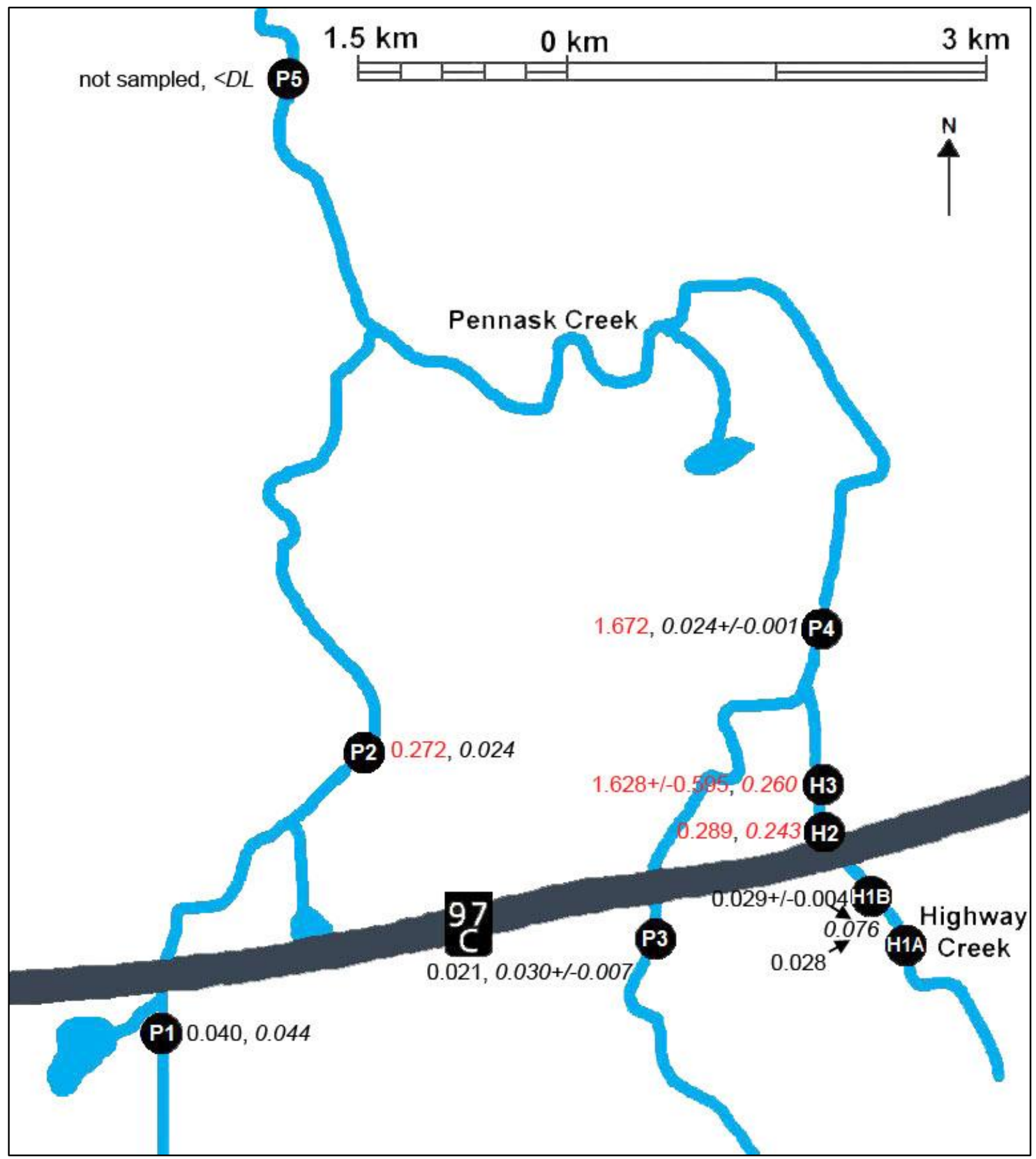

Figure 4.1: Dissolved aluminum concentration $(\mathrm{mg} / \mathrm{L})$ in water samples (regular text: July, italics: September; red: exceeds water quality guideline) 


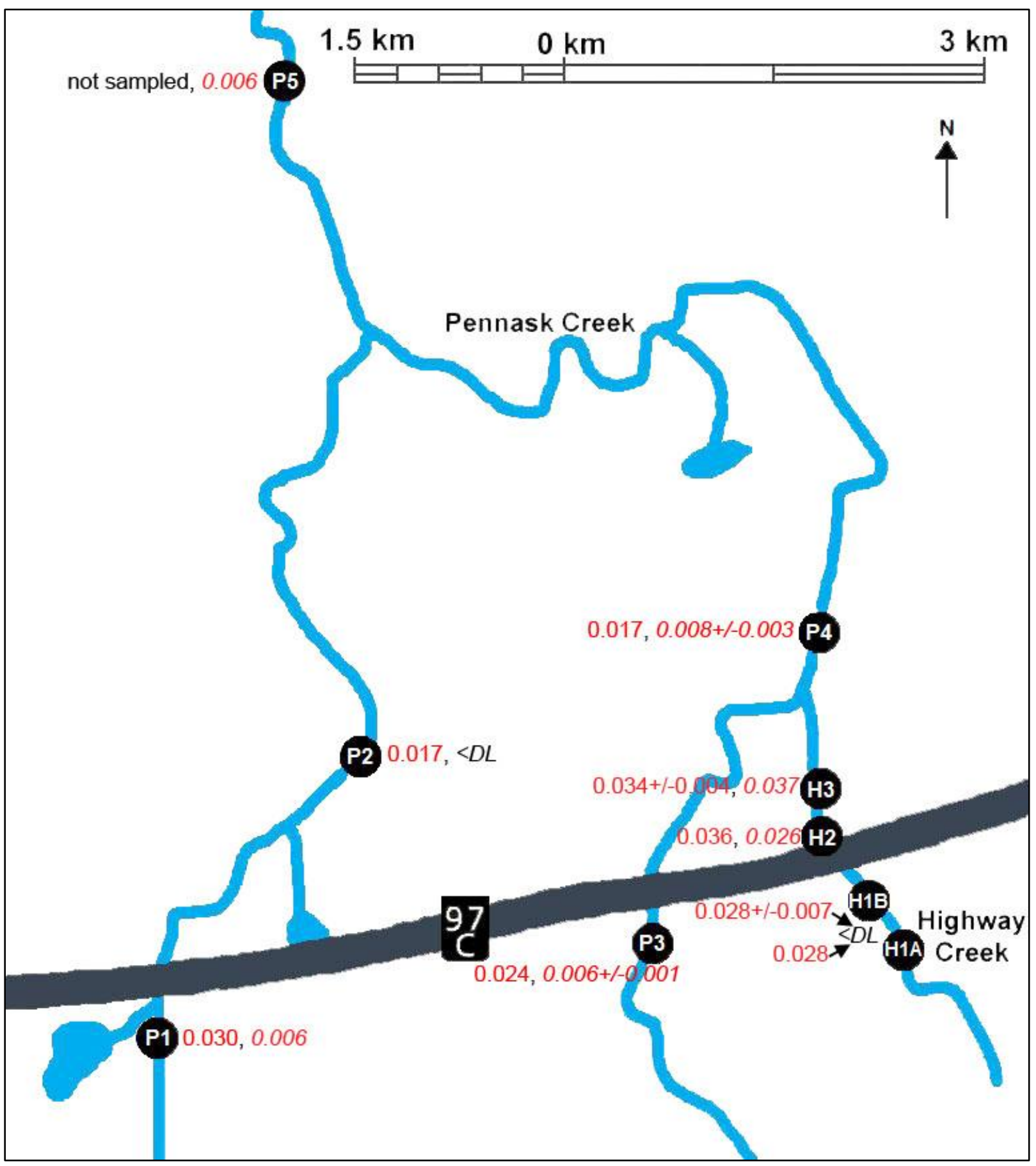

Figure 4.2: Total copper concentration $(\mathrm{mg} / \mathrm{L})$ in water samples (regular text: July, italics: September; red: exceeds water quality guideline) 


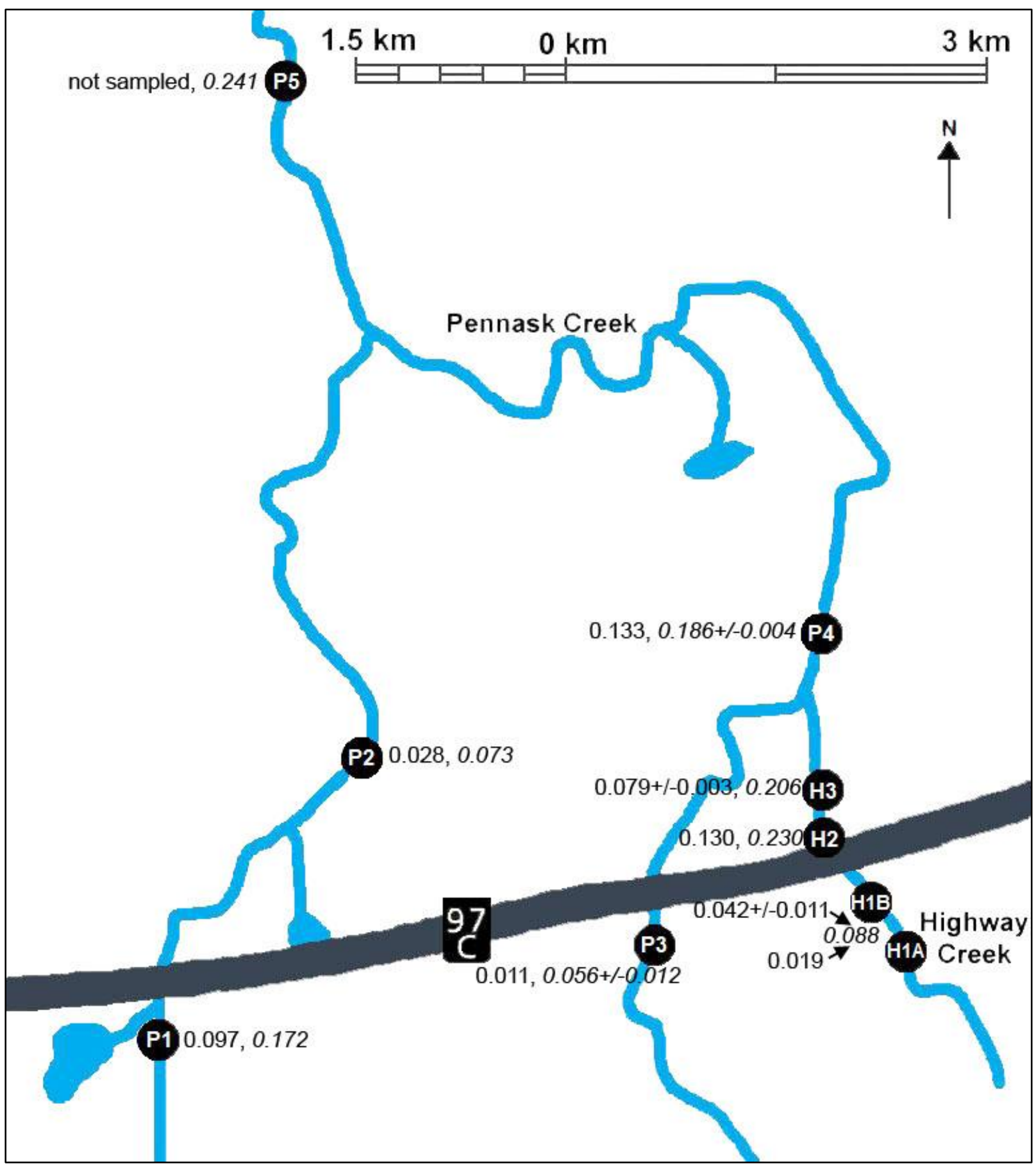

Figure 4.3: Total iron concentration $(\mathrm{mg} / \mathrm{L})$ in water samples (regular text: July, italics: September) 


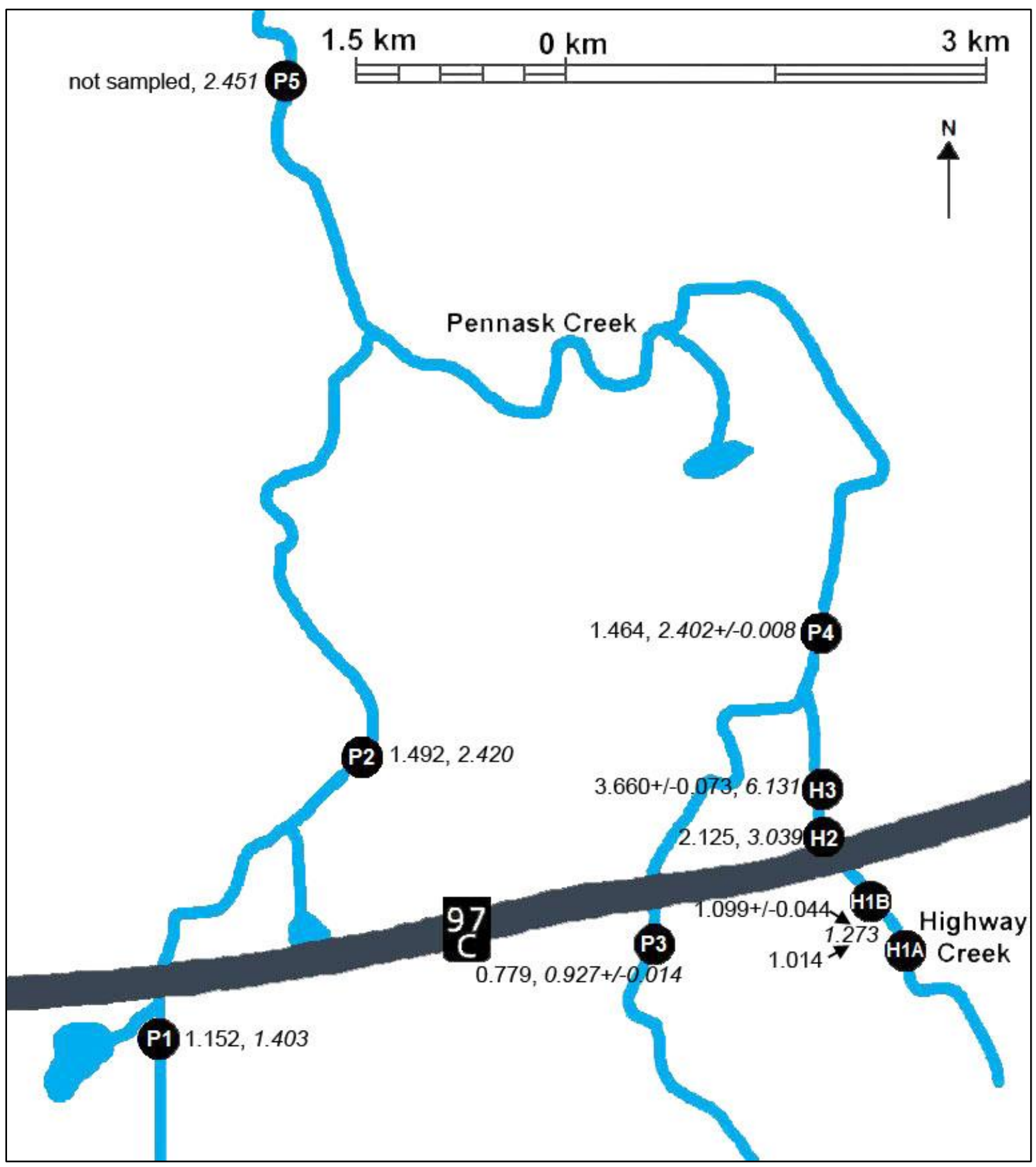

Figure 4.4: Total magnesium concentration $(\mathrm{mg} / \mathrm{L})$ in water samples (regular text: July, italics: September) 


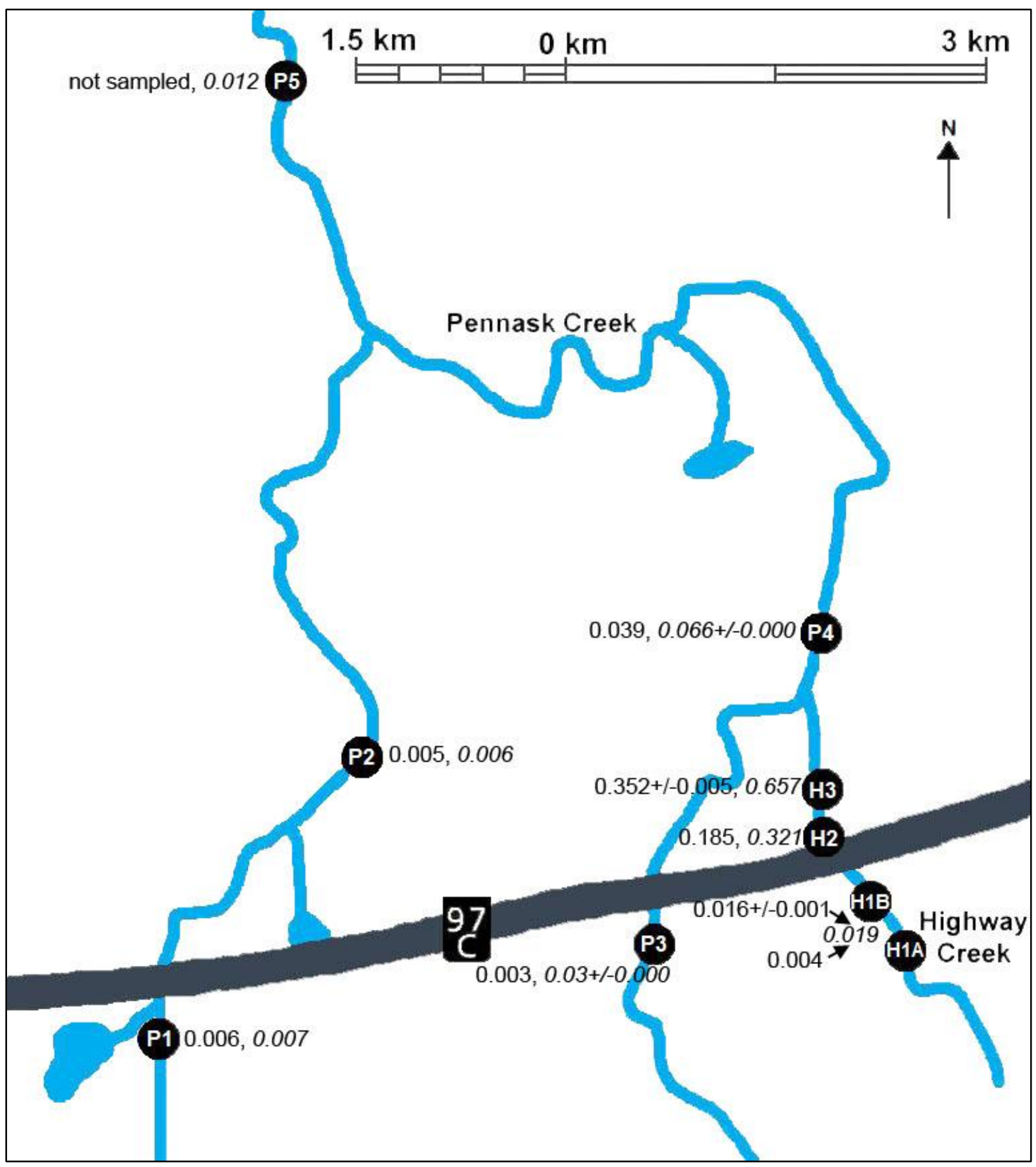

Figure 4.5: Total manganese concentration $(\mathrm{mg} / \mathrm{L})$ in water samples (regular text: July, italics: September) 


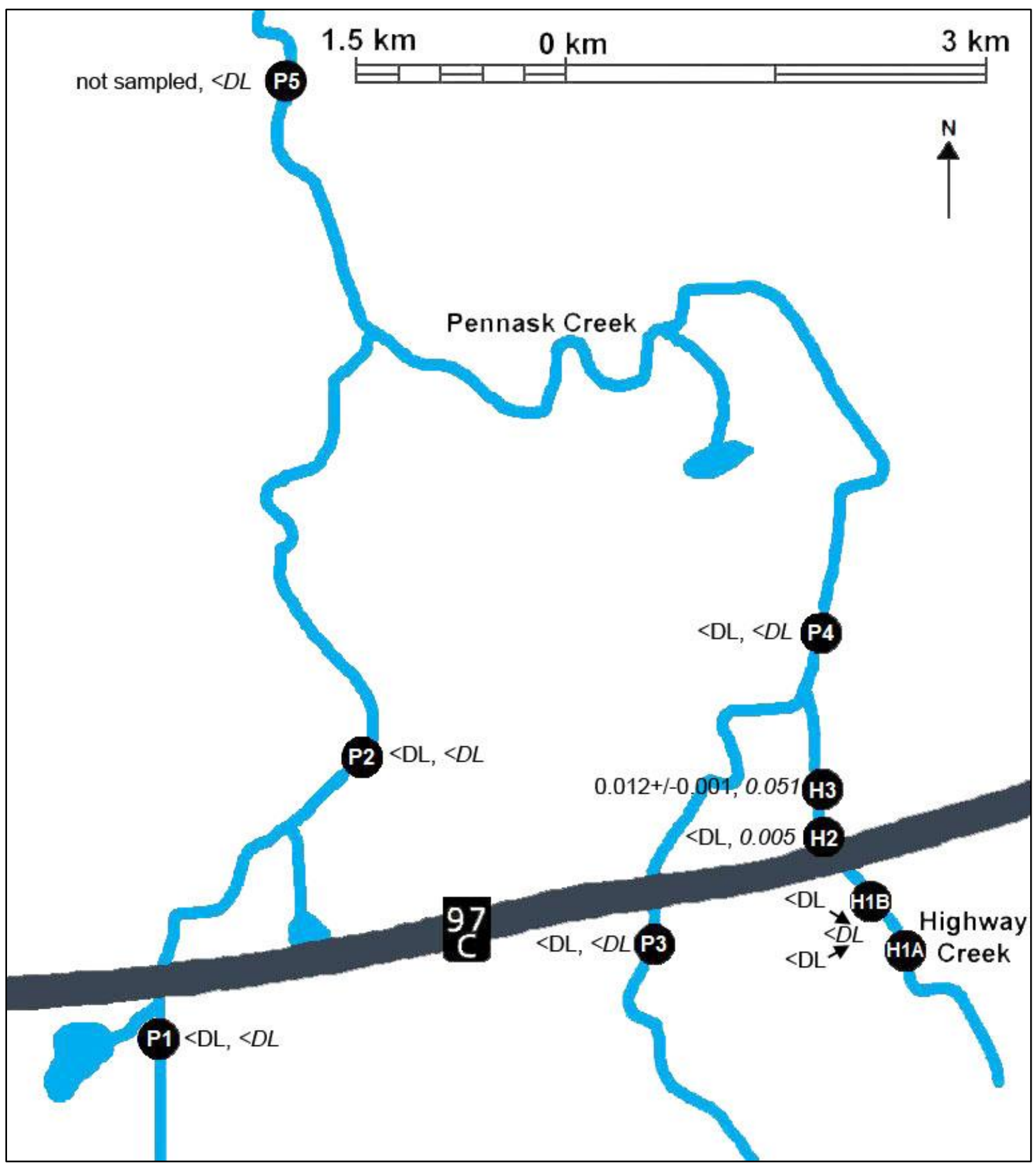

Figure 4.6: Total nickel concentration $(\mathrm{mg} / \mathrm{L})$ in water samples (regular text: July, italics: September) 


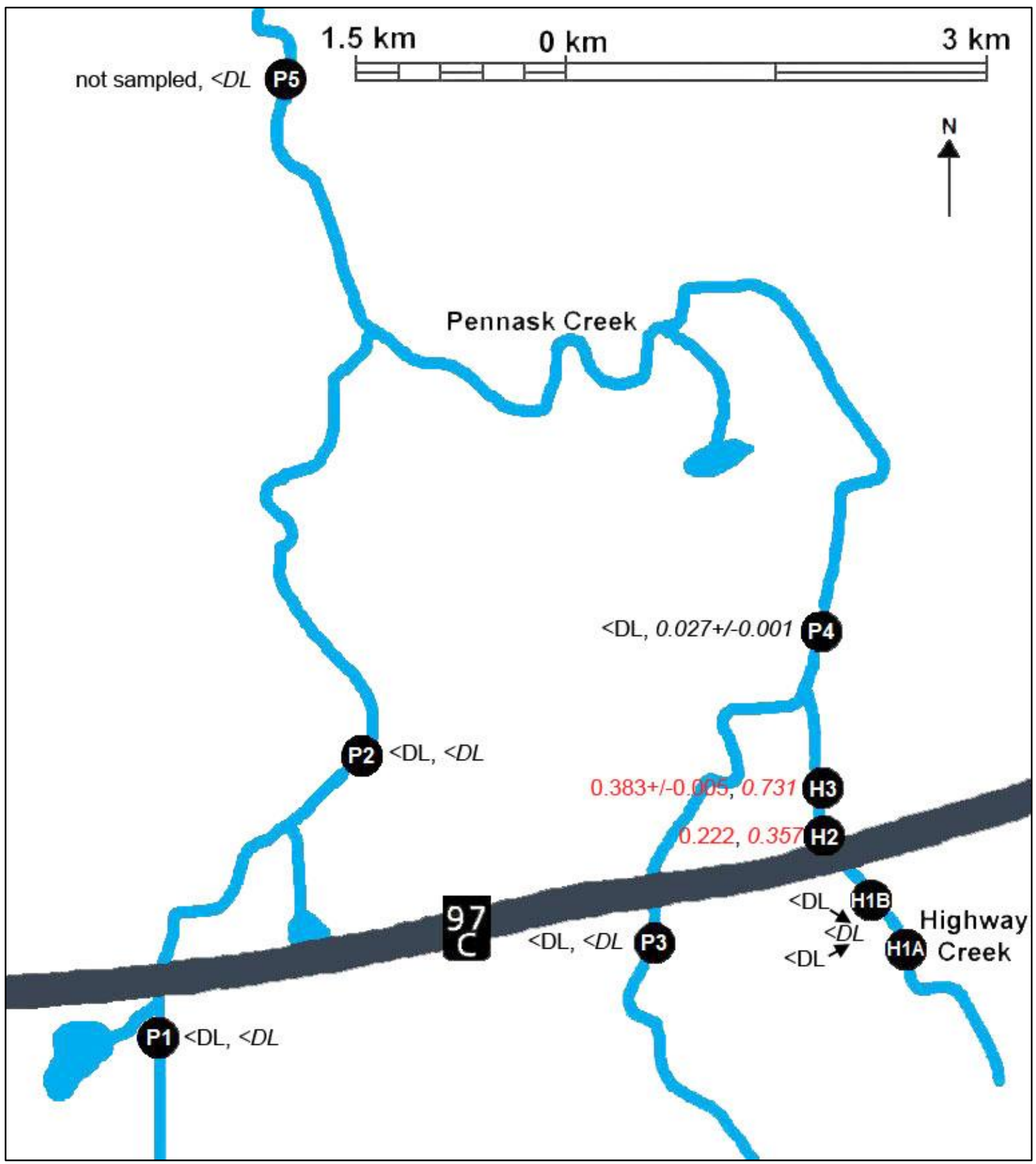

Figure 4.7: Total zinc concentration $(\mathrm{mg} / \mathrm{L})$ in water samples (regular text: July, italics: September; red: exceeds water quality guideline)

Overall, metal concentrations were higher in Highway Creek, downstream of Highway 97C (sites $\mathrm{H} 2$ and $\mathrm{H} 3$ ), than in Pennask Creek. Metal concentrations remain slightly elevated in Pennask Creek downstream of the confluence with Highway Creek. However, the increased 
water volume downstream of the confluence dilutes the metal contamination, and levels generally returned to near background before the outflow into Pennask Lake (site P5).

As discussed in Chapter 2, there are water quality guidelines for the protection of aquatic life that are recommended for use in BC and Canada. Tables 4.1-4.4 show those sites (shaded) where the metal concentration in the stream water exceeds at least one of these water quality guidelines (Table 2.1). Aluminum, copper and zinc concentrations all exceed at least one guideline value at one or more sample sites. Sites H2 and H3 (Highway Creek, downstream of Highway 97C) showed concentrations exceeding guideline values for all three of $\mathrm{Al}, \mathrm{Cu}$, and $\mathrm{Zn}$ concentrations. Copper concentrations were above guideline values for all sample sites in July, and for all sample sites in September that had concentrations above the detection limits.

\subsection{Sediment Quality}

Sediment quality parameters were compared to BC and CCME Sediment Quality Guidelines for the Protection of Aquatic Life (BCMOE 2006, CCME 2002) where applicable. Complete data tables are found in Appendix A.

\subsubsection{General chemistry}

General sediment chemistry results for July and September samples are provided in Tables A7 and A8 of Appendix A.

Sediment $\mathrm{pH}$ values for each sample site were very similar in both July and September, ranging from 5.5 to 6.5. The $\mathrm{pH}$ values for sites $\mathrm{H} 2, \mathrm{H} 3, \mathrm{P} 1$ and $\mathrm{P} 3$ were all below 6.0, while the other sites had $\mathrm{pH}$ values of 6.0 or greater.

In the $<2 \mathrm{~mm}$ fraction of the sediments, the fines $(<63 \mu \mathrm{m})$ content in all samples ranged from $1.1 \%$ to $31.4 \%$. Samples collected at sites $\mathrm{H} 1$ and $\mathrm{H} 3$ had the highest fines content in both months, with values of $17.7 \%$ and $8.7 \%$ in July, and $30.8 \%$ and $31.4 \%$ in September, respectively.

The organic matter content, as determined by loss on ignition, ranged from $4.0 \%$ to $11.3 \%$ for all samples. Total organic carbon content ranged from $0.8 \%$ to $2.6 \%$ for all samples. 


\subsubsection{Metal content}

Complete results for total and extractable metal concentration analyses for July and September sediment samples are provided in Tables A9 to A12 (Appendix A). Metals present above analytical detection limits in one or more sediment samples include aluminum, arsenic, barium, beryllium, cadmium, cobalt, copper, iron, magnesium, manganese, molybdenum, nickel, lead, and zinc. A summary of results for the detected metals are provided in Tables 4.5 to 4.8 . A graphical presentation of total and extractable metal contents in July and September sediment samples are provided in Figures 4.8 to 4.14 to illustrate the spatial patterns of contamination in the Pennask Creek watershed. Total metal content is shown in bold and extractable metal content is shown in brackets, with July concentrations in regular text and September concentrations in italics. Site P5 was not sampled in July. 
Table 4.5: Total metal content of July sediment samples (strong acid leachable) $(n=3)$

\begin{tabular}{|c|c|c|c|c|c|c|c|c|c|c|c|c|c|c|}
\hline \multirow{3}{*}{$\begin{array}{c}\text { Metal } \\
(\mathrm{mg} / \mathrm{kg}, \mathrm{dw})\end{array}$} & \multicolumn{14}{|c|}{ Sample ID } \\
\hline & \multicolumn{2}{|l|}{ H1 } & \multicolumn{2}{|c|}{$\mathrm{H2}$} & \multicolumn{2}{|c|}{ H3 } & \multicolumn{2}{|c|}{ P1 } & \multicolumn{2}{|l|}{$\mathbf{P 2}$} & \multicolumn{2}{|l|}{$\mathbf{P 3}$} & \multicolumn{2}{|l|}{ P4 } \\
\hline & Mean & SD & Mean & SD & Mean & SD & Mean & SD & Mean & SD & Mean & SD & Mean & SD \\
\hline Al & 16976.9 & 456.3 & 23507.1 & 507.4 & 24983.7 & 1719.9 & 18188.4 & 489.2 & 14873.8 & 286.2 & 16198.9 & 844.0 & 19289.1 & 348.1 \\
\hline As & 11.4 & 0.4 & 7.5 & 0.9 & 7.6 & 0.4 & 1.5 & 0.2 & 2.2 & 0.1 & 12.1 & 0.1 & 21.8 & 0.4 \\
\hline $\mathbf{B a}$ & 189.1 & 4.0 & 124.4 & 0.4 & 97.2 & 2.7 & 180.5 & 4.7 & 162.4 & 0.9 & 148.3 & 2.4 & 173.4 & 3.8 \\
\hline Co & 16.1 & 0.4 & 21.6 & 0.2 & 15.4 & 0.3 & 11.3 & 0.2 & 9.5 & 0.1 & 7.9 & 0.1 & 38.8 & 0.3 \\
\hline $\mathbf{C u}$ & 40.3 & 0.9 & 210.4 & 3.3 & 166.8 & 3.4 & 31.1 & 0.8 & 21.6 & 0.2 & 27.6 & 0.2 & 71.7 & 1.5 \\
\hline $\mathbf{F e}$ & 19707.7 & 566.4 & 25881.1 & 103.8 & 19944.6 & 402.9 & 18176.3 & 355.0 & 19491.9 & 172.6 & 19417.2 & 217.2 & 23376.4 & 207.0 \\
\hline Mg & 4753.2 & 146.6 & 6151.7 & 71.7 & 3101.9 & 71.7 & 5777.5 & 142.2 & 5071.2 & 67.3 & 4394.8 & 47.2 & 4395.2 & 61.0 \\
\hline Mn & 1421.9 & 38.2 & 1002.6 & 7.2 & 558.0 & 17.2 & 722.9 & 11.6 & 1280.4 & 13.3 & 564.9 & 12.8 & 3076.8 & 42.5 \\
\hline Mo & 2.4 & 0.1 & 2.3 & 0.1 & 3.8 & 0.1 & 1.8 & 0.0 & 1.0 & 0.0 & 1.7 & 0.0 & 3.0 & 0.0 \\
\hline $\mathbf{N i}$ & 37.5 & 1.0 & 34.2 & 1.1 & 42.9 & 1.4 & 7.1 & 1.3 & 4.2 & 0.2 & 5.3 & 1.1 & 77.8 & 1.8 \\
\hline $\mathbf{P b}$ & 3.1 & 0.1 & 8.4 & 0.5 & 0.8 & 0.2 & 0.3 & 0.1 & 0.7 & 0.2 & 1.3 & 0.1 & 1.5 & 0.2 \\
\hline $\mathrm{Zn}$ & 395.7 & 5.6 & 528.3 & 4.9 & 514.5 & 9.7 & 62.1 & 1.5 & 99.0 & 1.1 & 140.4 & 8.8 & 743.2 & 14.6 \\
\hline
\end{tabular}

shading - value exceeds sediment quality guideline (ISQG or LEL) shown in Table 2.2 
Table 4.6: Total metal content of September sediment samples (strong acid leachable) $(n=3)$

\begin{tabular}{|c|c|c|c|c|c|c|c|c|c|c|c|c|c|c|c|c|}
\hline \multirow{3}{*}{$\begin{array}{l}\text { Metal } \\
(\mathrm{mg} / \mathrm{kg} \\
\text {, dw) }\end{array}$} & \multicolumn{16}{|c|}{ Sample ID } \\
\hline & \multicolumn{2}{|c|}{ H1 } & \multicolumn{2}{|c|}{$\mathrm{H} 2$} & \multicolumn{2}{|c|}{ H3 } & \multicolumn{2}{|c|}{$\mathbf{P 1}$} & \multicolumn{2}{|l|}{ P2 } & \multicolumn{2}{|c|}{ P3 } & \multicolumn{2}{|c|}{ P4 } & \multicolumn{2}{|c|}{ P5 } \\
\hline & Mean & SD & Mean & SD & Mean & SD & Mean & SD & Mean & SD & Mean & SD & Mean & SD & Mean & SD \\
\hline Al & $\begin{array}{r}17015 . \\
0\end{array}$ & $\begin{array}{r}342 . \\
5\end{array}$ & $\begin{array}{r}31181 . \\
1\end{array}$ & $\begin{array}{r}919 . \\
3\end{array}$ & $\begin{array}{r}21911 . \\
4\end{array}$ & $\begin{array}{r}303 . \\
7\end{array}$ & $\begin{array}{r}16380 . \\
9\end{array}$ & $\begin{array}{r}169 . \\
7\end{array}$ & $\begin{array}{r}15810 . \\
7\end{array}$ & $\begin{array}{r}382 . \\
5\end{array}$ & $\begin{array}{r}13769 . \\
2\end{array}$ & $\begin{array}{r}710 . \\
8\end{array}$ & $\begin{array}{r}16907 . \\
2\end{array}$ & $\begin{array}{r}534 . \\
5\end{array}$ & $\begin{array}{r}11025 . \\
4\end{array}$ & 90.4 \\
\hline As & 15.7 & 0.5 & 4.1 & 0.3 & 3.6 & 0.4 & 2.2 & 0.2 & 2.5 & 0.2 & 9.5 & 0.2 & 10.1 & 0.2 & 0.2 & 0.1 \\
\hline $\mathbf{B a}$ & 203.1 & 5.3 & 133.6 & 1.3 & 120.1 & 2.1 & 190.3 & 0.9 & 197.9 & 1.9 & 158.5 & 3.3 & 157.1 & 2.1 & 164.2 & 2.4 \\
\hline $\mathrm{Co}$ & 15.4 & 0.4 & 22.3 & 0.2 & 14.0 & 0.3 & 10.1 & 0.1 & 18.2 & 0.2 & 6.1 & 0.0 & 24.2 & 0.3 & 9.3 & 0.1 \\
\hline $\mathrm{Cu}$ & 49.3 & 1.5 & 191.4 & 3.5 & 130.9 & 2.5 & 36.7 & 0.2 & 22.8 & 0.5 & 23.4 & 0.7 & 51.7 & 0.5 & 16.5 & 0.1 \\
\hline $\mathbf{F e}$ & $\begin{array}{r}21968 . \\
1\end{array}$ & $\begin{array}{r}406 . \\
4\end{array}$ & $\begin{array}{r}27213 . \\
0\end{array}$ & $\begin{array}{r}183 . \\
1\end{array}$ & $\begin{array}{r}18591 . \\
4\end{array}$ & $\begin{array}{r}388 . \\
3\end{array}$ & $\begin{array}{r}20872 . \\
3\end{array}$ & $\begin{array}{r}143 . \\
3\end{array}$ & $\begin{array}{r}23913 . \\
5\end{array}$ & $\begin{array}{r}501 . \\
2\end{array}$ & $\begin{array}{r}17342 . \\
6\end{array}$ & $\begin{array}{r}137 . \\
7\end{array}$ & $\begin{array}{r}18547 . \\
8\end{array}$ & $\begin{array}{r}176 . \\
2\end{array}$ & $\begin{array}{r}15758 . \\
2\end{array}$ & $\begin{array}{r}206 . \\
3\end{array}$ \\
\hline Mg & 5595.8 & $\begin{array}{r}114 . \\
7\end{array}$ & 6812.3 & 63.7 & 4041.4 & 94.5 & 5545.8 & 28.3 & 4671.2 & 72.5 & 3826.4 & 43.6 & 4121.6 & 37.1 & 3461.7 & 36.9 \\
\hline Mn & 1190.3 & 26.9 & 1003.8 & 15.3 & 528.5 & 13.9 & 473.8 & 19.3 & 2341.0 & 29.4 & 194.8 & 2.4 & 1669.7 & 16.1 & 487.1 & 3.3 \\
\hline Mo & 2.8 & 0.1 & 1.8 & 0.0 & 1.8 & 0.1 & 1.4 & 0.0 & 0.9 & 0.0 & 1.6 & 0.1 & 1.4 & 0.0 & 0.1 & 0.0 \\
\hline $\mathbf{N i}$ & 33.0 & 1.2 & 36.8 & 1.3 & 22.9 & 0.8 & 5.2 & 0.3 & 6.6 & 0.8 & 1.2 & 0.3 & 37.2 & 1.2 & 4.5 & 0.5 \\
\hline$\overline{\mathbf{P b}}$ & 4.6 & 0.1 & 11.3 & 0.2 & $<0.1$ & 0.0 & 0.7 & 0.2 & 1.8 & 0.1 & 0.4 & 0.2 & 0.4 & 0.1 & 0.8 & 0.2 \\
\hline$\overline{Z n}$ & 452.4 & 11.4 & 658.5 & 4.9 & 388.5 & 7.3 & 54.2 & 0.2 & 90.2 & 1.3 & 113.6 & 2.4 & 540.3 & 5.1 & 329.8 & 3.6 \\
\hline
\end{tabular}

shading - value exceeds sediment quality guideline (ISQG or LEL) shown in Table 2.2 
Table 4.7: Extractable metal content of July sediment samples (weak acid leachable)

$(n=3)$

\begin{tabular}{|c|c|c|c|c|c|c|c|c|c|c|c|c|c|c|}
\hline \multirow{3}{*}{$\begin{array}{c}\text { Metal } \\
(\mathrm{mg} / \mathrm{kg}, \mathrm{dw})\end{array}$} & \multicolumn{14}{|c|}{ Sample ID } \\
\hline & \multicolumn{2}{|c|}{ H1 } & \multicolumn{2}{|c|}{$\mathrm{H} 2$} & \multicolumn{2}{|c|}{$\mathrm{H3}$} & \multicolumn{2}{|c|}{ P1 } & \multicolumn{2}{|c|}{$\mathbf{P 2}$} & \multicolumn{2}{|c|}{ P3 } & \multicolumn{2}{|c|}{ P4 } \\
\hline & Mean & SD & Mean & SD & Mean & SD & Mean & SD & Mean & SD & Mean & SD & Mean & SD \\
\hline Al & 2286.0 & 132.2 & 5310.3 & 1590.2 & 6015.4 & 16.6 & 2555.1 & 26.7 & 2125.7 & 101.1 & 2581.4 & 90.4 & 3663.6 & 87.9 \\
\hline As & 1.8 & 0.1 & 1.6 & 0.1 & 1.4 & 0.0 & $<\mathrm{DL}$ & - & $<\mathrm{DL}$ & - & 1.8 & 0.1 & 2.9 & 0.0 \\
\hline Ba & 52.4 & 2.5 & 21.5 & 0.5 & 18.5 & 0.1 & 51.5 & 1.9 & 49.7 & 3.1 & 42.4 & 1.9 & 49.7 & 1.3 \\
\hline Be & 0.1 & 0.0 & 0.3 & 0.0 & 0.3 & $\overline{0.0}$ & $<\mathrm{DL}$ & - & $\angle \mathrm{DL}$ & - & $<\mathrm{DL}$ & - & 0.2 & 0.0 \\
\hline $\mathbf{C d}$ & $\angle \mathrm{DL}$ & - & $\angle \mathrm{DL}$ & - & $<\mathrm{DL}$ & - & $<\mathrm{DL}$ & - & $\angle \mathrm{DL}$ & - & $<\mathrm{DL}$ & - & 4.1 & 0.2 \\
\hline Co & 5.1 & 0.2 & 6.7 & 0.1 & 5.0 & 0.0 & 2.6 & 0.1 & 2.3 & 0.1 & 1.5 & 0.1 & 14.3 & 0.3 \\
\hline $\mathbf{C u}$ & 10.1 & 0.5 & 75.0 & 1.8 & 62.1 & 0.3 & 7.0 & 0.3 & 4.4 & 0.3 & 6.6 & 0.4 & 23.5 & 0.6 \\
\hline $\mathbf{F e}$ & 3203.9 & 113.9 & 4243.5 & 60.7 & 4206.3 & 6.4 & 3066.6 & 51.4 & 3723.3 & 126.8 & 3406.7 & 94.8 & 4619.2 & 39.5 \\
\hline Mg & 605.7 & 32.6 & 567.5 & 15.2 & 262.9 & 1.5 & 849.0 & 25.3 & 672.1 & 30.4 & 570.6 & 21.1 & 434.3 & 8.7 \\
\hline Mn & 544.5 & 26.2 & 343.4 & 5.3 & 194.9 & 2.0 & 253.5 & 8.7 & 496.8 & 21.8 & 191.2 & 7.4 & 1102.8 & 15.1 \\
\hline $\mathrm{Ni}$ & 9.0 & 0.6 & 7.8 & 0.2 & 12.9 & 0.1 & $<\mathrm{DL}$ & - & $<\mathrm{DL}$ & - & $<\mathrm{DL}$ & - & 27.4 & 0.8 \\
\hline $\mathbf{P b}$ & 1.0 & 0.1 & 2.9 & 0.1 & 0.2 & 0.0 & 0.3 & 0.1 & 0.4 & 0.1 & 0.7 & 0.0 & 0.5 & 0.0 \\
\hline $\mathbf{Z n}$ & 118.2 & 5.1 & 176.1 & 3.1 & 176.0 & 0.7 & 11.9 & 0.5 & 26.7 & 1.8 & 29.4 & 1.2 & 248.5 & 5.3 \\
\hline
\end{tabular}

$<\mathrm{DL}-$ below detection limit 
Table 4.8: Extractable metal content of September sediment samples (weak acid leachable)

$$
(n=3)
$$

\begin{tabular}{|c|c|c|c|c|c|c|c|c|c|c|c|c|c|c|c|c|}
\hline \multirow{3}{*}{$\begin{array}{c}\text { Metal } \\
(\mathrm{mg} / \mathrm{kg}, \mathrm{dw})\end{array}$} & \multicolumn{16}{|c|}{ Sample ID } \\
\hline & \multicolumn{2}{|c|}{ H1 } & \multicolumn{2}{|c|}{ H2 } & \multicolumn{2}{|c|}{ H3 } & \multicolumn{2}{|c|}{ P1 } & \multicolumn{2}{|c|}{ P2 } & \multicolumn{2}{|c|}{ P3 } & \multicolumn{2}{|c|}{ P4 } & \multicolumn{2}{|c|}{ P5 } \\
\hline & Mean & SD & Mean & SD & Mean & SD & Mean & SD & Mean & SD & Mean & SD & Mean & SD & Mean & SD \\
\hline Al & 1750.9 & 19.2 & 8846.7 & 124.0 & 6623.0 & 54.8 & 1934.9 & 38.0 & 1624.7 & 19.2 & 1980.3 & 64.4 & 2660.4 & 33.1 & 1101.4 & 25.2 \\
\hline As & 1.7 & 0.0 & $<\mathrm{DL}$ & - & $<\mathrm{DL}$ & - & $<\mathrm{DL}$ & - & $<\mathrm{DL}$ & - & 1.9 & 0.1 & 1.9 & 0.1 & $<\mathrm{DL}$ & - \\
\hline$\overline{\mathbf{B a}}$ & 44.6 & 1.0 & 17.8 & 0.3 & 19.1 & 0.5 & 51.2 & 1.4 & 57.4 & 1.1 & 27.1 & 2.1 & 40.2 & 0.7 & 39.5 & 0.7 \\
\hline $\mathbf{B e}$ & 0.1 & 0.0 & 0.3 & 0.0 & 0.2 & 0.0 & $\angle \mathrm{DL}$ & - & $\angle \mathrm{DL}$ & - & $\angle \mathrm{DL}$ & - & 0.1 & 0.0 & $\angle \mathrm{DL}$ & - \\
\hline Cd & $<\mathrm{DL}$ & - & $<\mathrm{DL}$ & - & $<\mathrm{DL}$ & - & $<\mathrm{DL}$ & - & $<\mathrm{DL}$ & - & $<\mathrm{DL}$ & - & 0.3 & 0.0 & $<\mathrm{DL}$ & - \\
\hline Co & 4.2 & 0.1 & 6.4 & 0.1 & 3.8 & 0.0 & 1.9 & 0.0 & 5.2 & 0.0 & 0.9 & 0.0 & 7.6 & 0.0 & 2.2 & 0.0 \\
\hline $\mathbf{C u}$ & 10.1 & 0.2 & 61.0 & 0.6 & 45.2 & 0.9 & 7.5 & 0.1 & 4.3 & 0.0 & 5.0 & 0.1 & 15.2 & 0.2 & 4.0 & 0.1 \\
\hline $\mathbf{F e}$ & 2593.2 & 65.7 & 3505.7 & 43.0 & 2566.8 & 23.4 & 2724.9 & 71.0 & 4842.8 & 63.1 & 2653.7 & 73.2 & 2754.1 & 24.2 & 1620.0 & 34.5 \\
\hline $\mathrm{Mg}$ & 500.6 & 13.0 & 628.3 & 14.0 & 350.3 & 5.3 & 630.2 & 19.9 & 440.5 & 3.0 & 389.8 & 17.1 & 361.5 & 2.2 & 364.0 & 9.8 \\
\hline Mn & 410.9 & 8.1 & 316.9 & 3.4 & 161.5 & 1.1 & 127.8 & 3.4 & 812.5 & 6.0 & 31.0 & 1.1 & 602.8 & 3.1 & 157.4 & 4.1 \\
\hline $\mathbf{N i}$ & 7.8 & 0.2 & 7.3 & 0.1 & 5.0 & 0.0 & $<\mathrm{DL}$ & & $<\mathrm{DL}$ & - & $\angle \mathrm{DL}$ & - & 10.2 & 0.2 & 1.1 & 0.1 \\
\hline $\mathbf{P b}$ & 1.0 & 0.1 & 3.1 & 0.2 & $<0.1$ & 0.0 & 0.4 & 0.0 & 0.9 & 0.4 & 0.3 & 0.0 & 0.2 & 0.0 & 0.5 & 0.0 \\
\hline $\mathbf{Z n}$ & 131.1 & 2.8 & 212.0 & 0.7 & 121.5 & 2.2 & 7.8 & 0.1 & 19.6 & 0.1 & 19.8 & 0.8 & 162.8 & 2.8 & 109.3 & 2.0 \\
\hline
\end{tabular}

$<\mathrm{DL}$ - below detection limit 


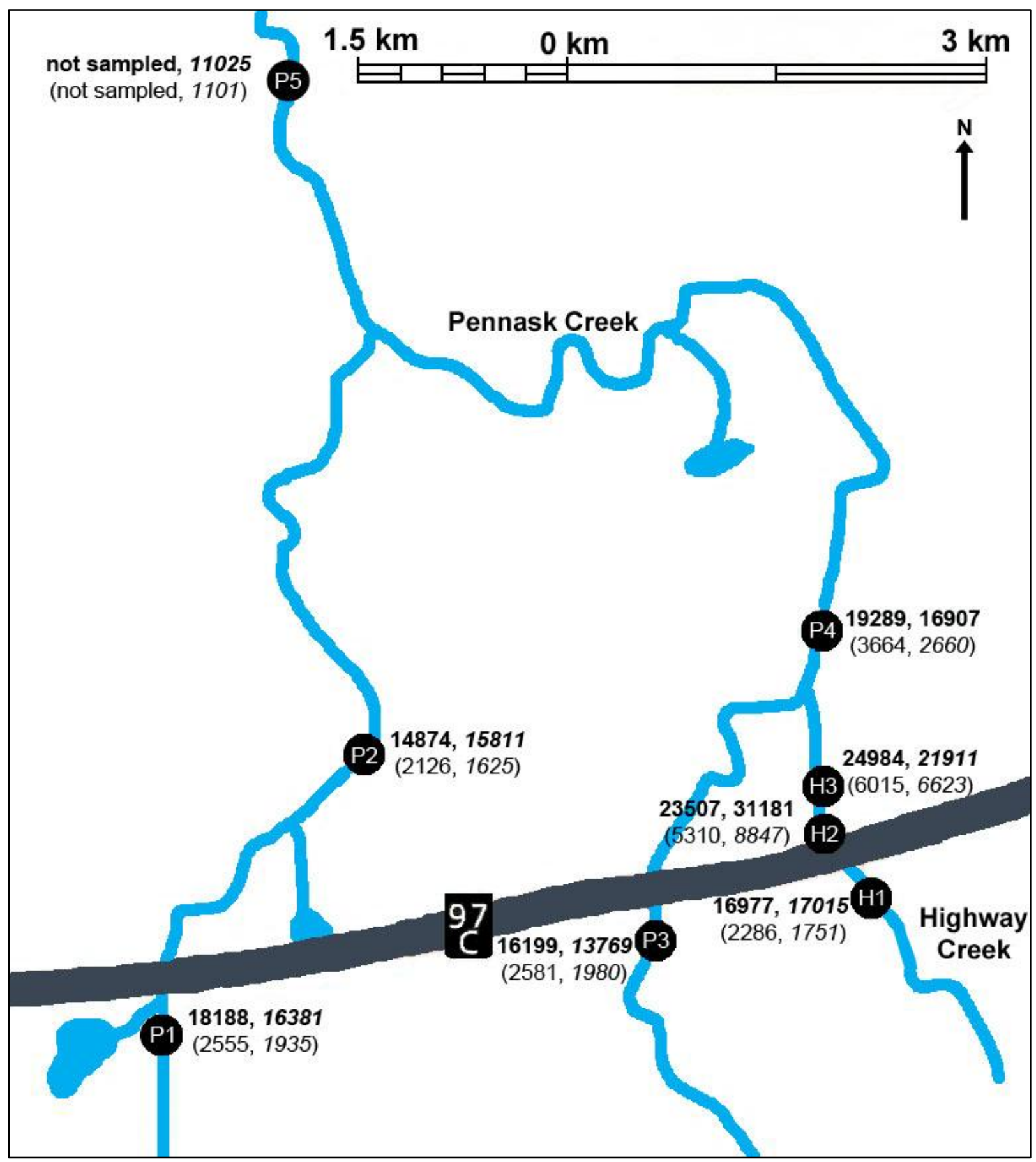

Figure 4.8: Aluminum content $(\mathrm{mg} / \mathrm{kg}, \mathrm{dw})$ of sediment samples (bold $=$ total metal content, brackets $=$ extractable metal content) (regular text: July, italics: September) 


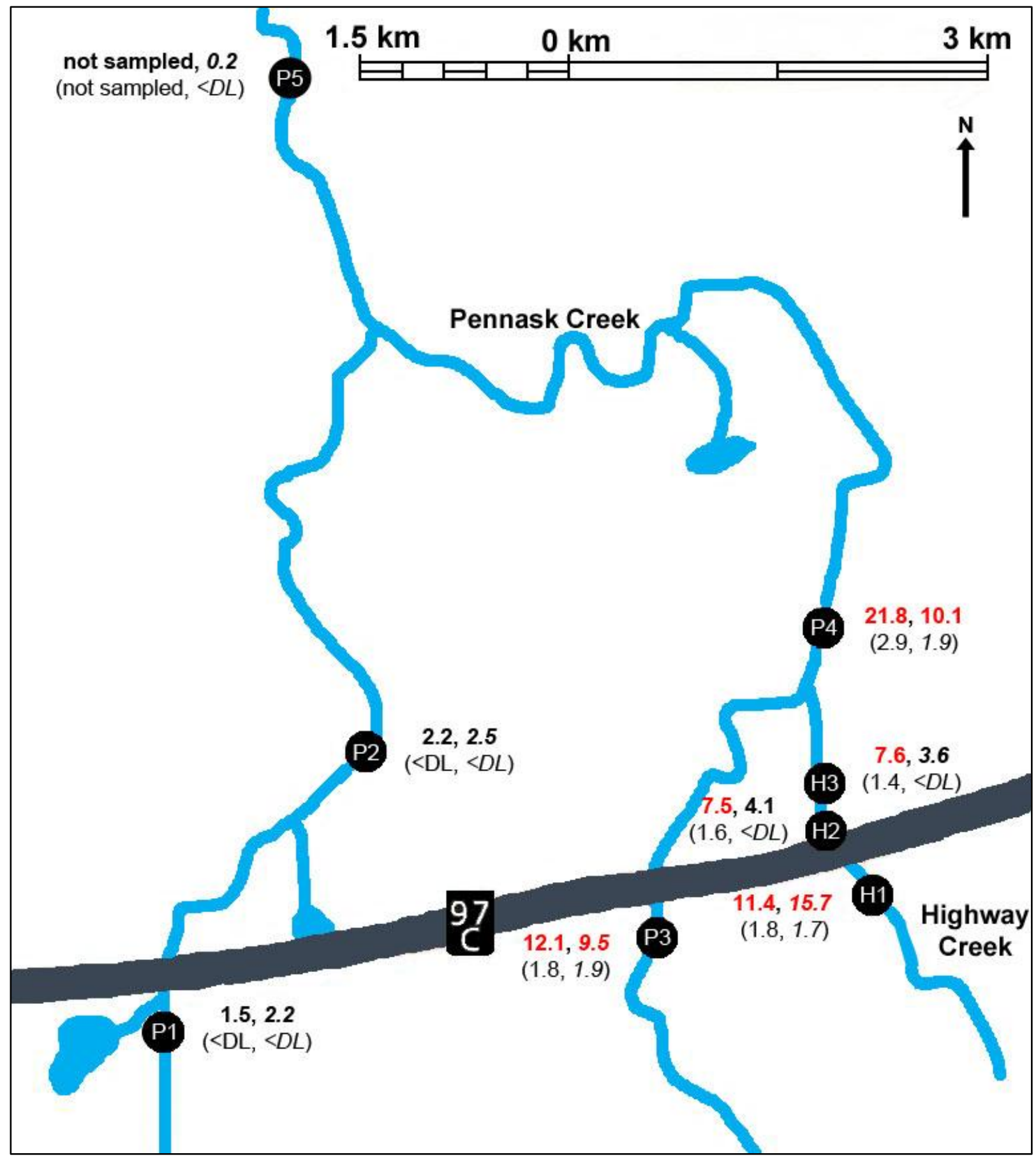

Figure 4.9: Arsenic content $(\mathrm{mg} / \mathrm{kg}, \mathrm{dw})$ of sediment samples

(bold $=$ total metal content, brackets $=$ extractable metal content, regular text $=$ July, italics $=$ September; red: exceeds sediment quality guideline; $\angle \mathrm{DL}=$ below detection limits) 


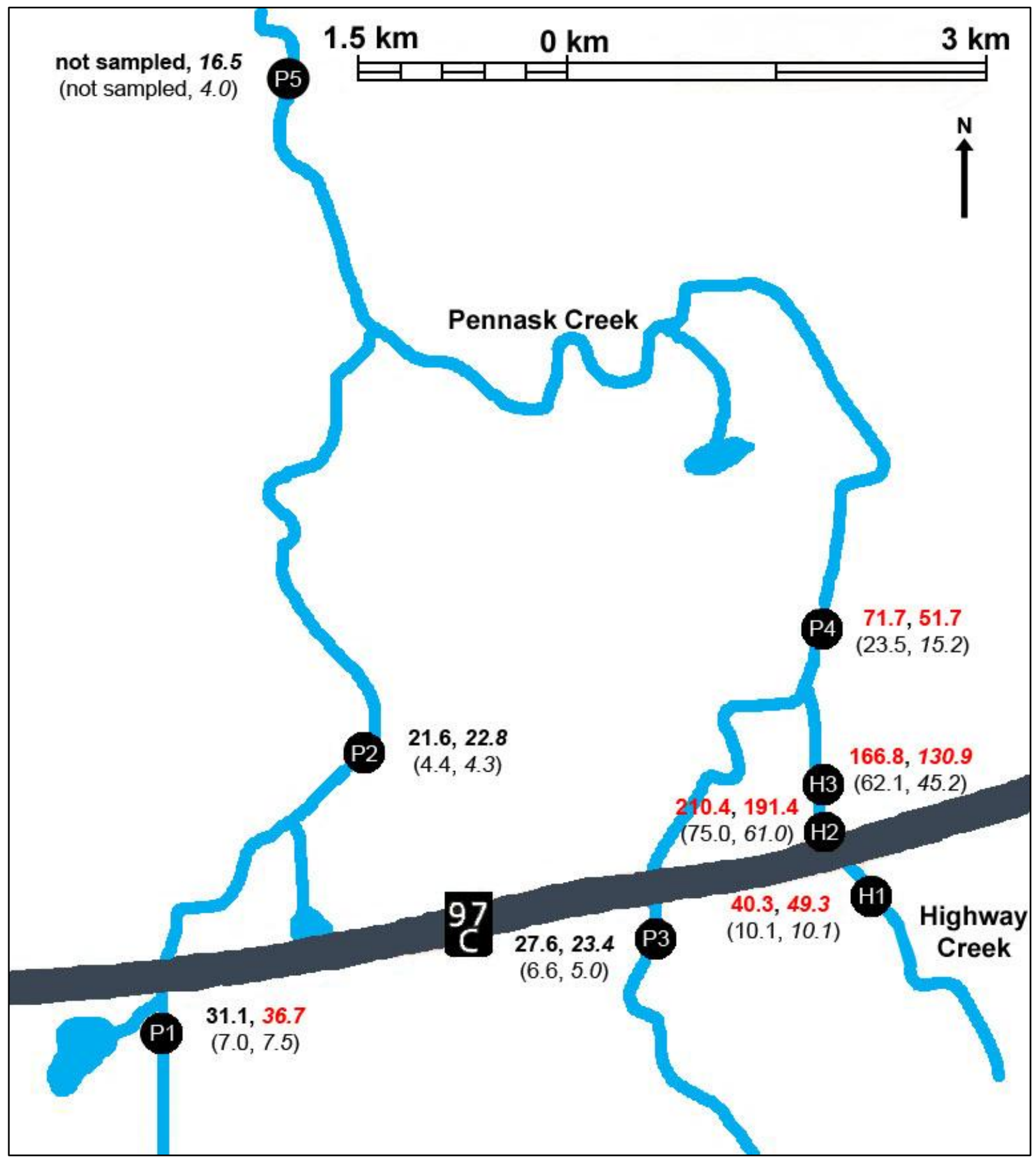

Figure 4.10: Copper content $(\mathrm{mg} / \mathrm{kg}, \mathrm{dw})$ of sediment samples

(bold $=$ total metal content, brackets $=$ extractable metal content, regular text $=$ July, italics $=$ September; red: exceeds sediment quality guideline) 


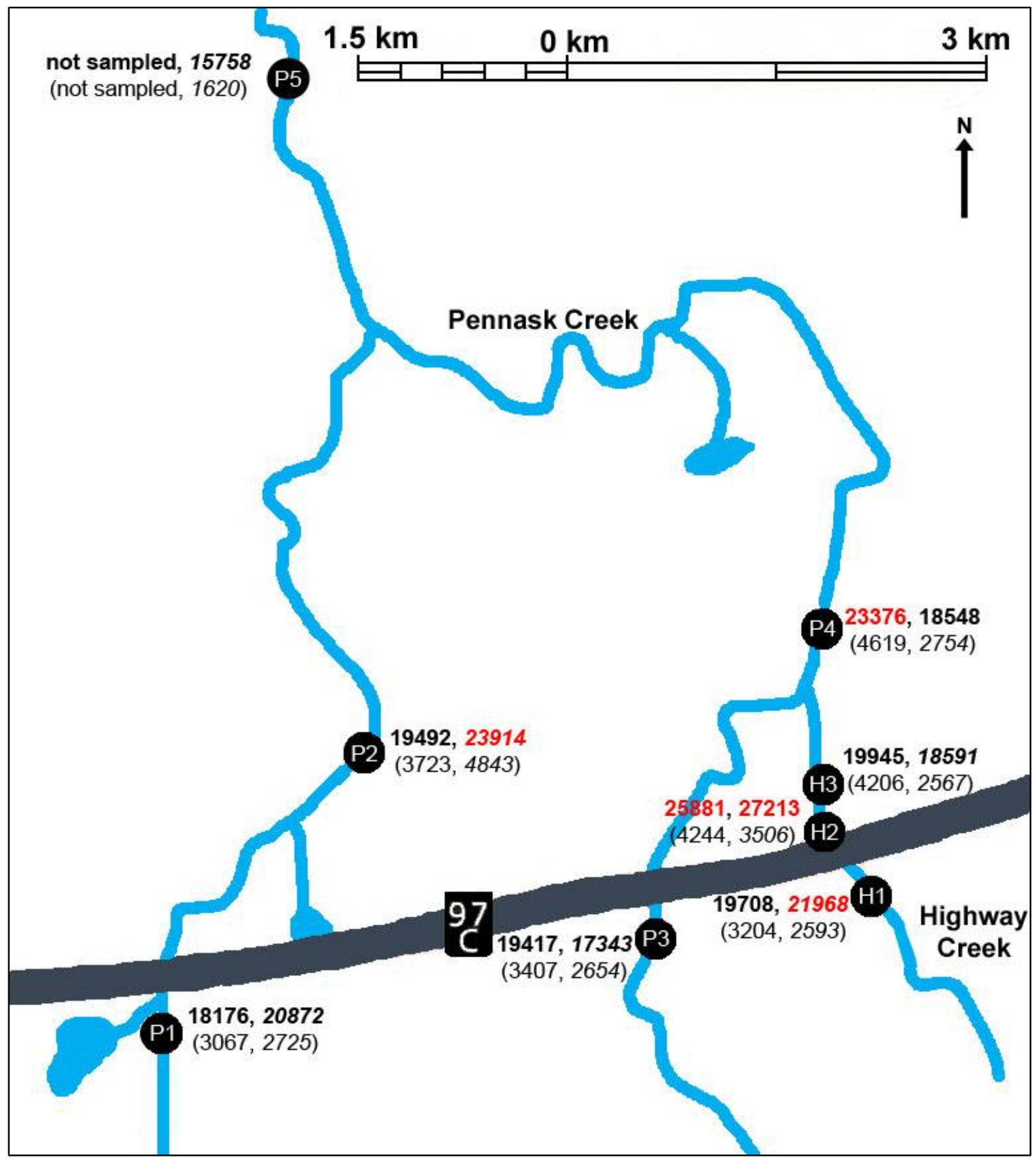

Figure 4.11: Iron content $(\mathrm{mg} / \mathrm{kg}, \mathrm{dw})$ of sediment samples

(bold $=$ total metal content, brackets $=$ extractable metal content, regular text $=$ July, italics $=$ September; red: exceeds sediment quality guideline) 


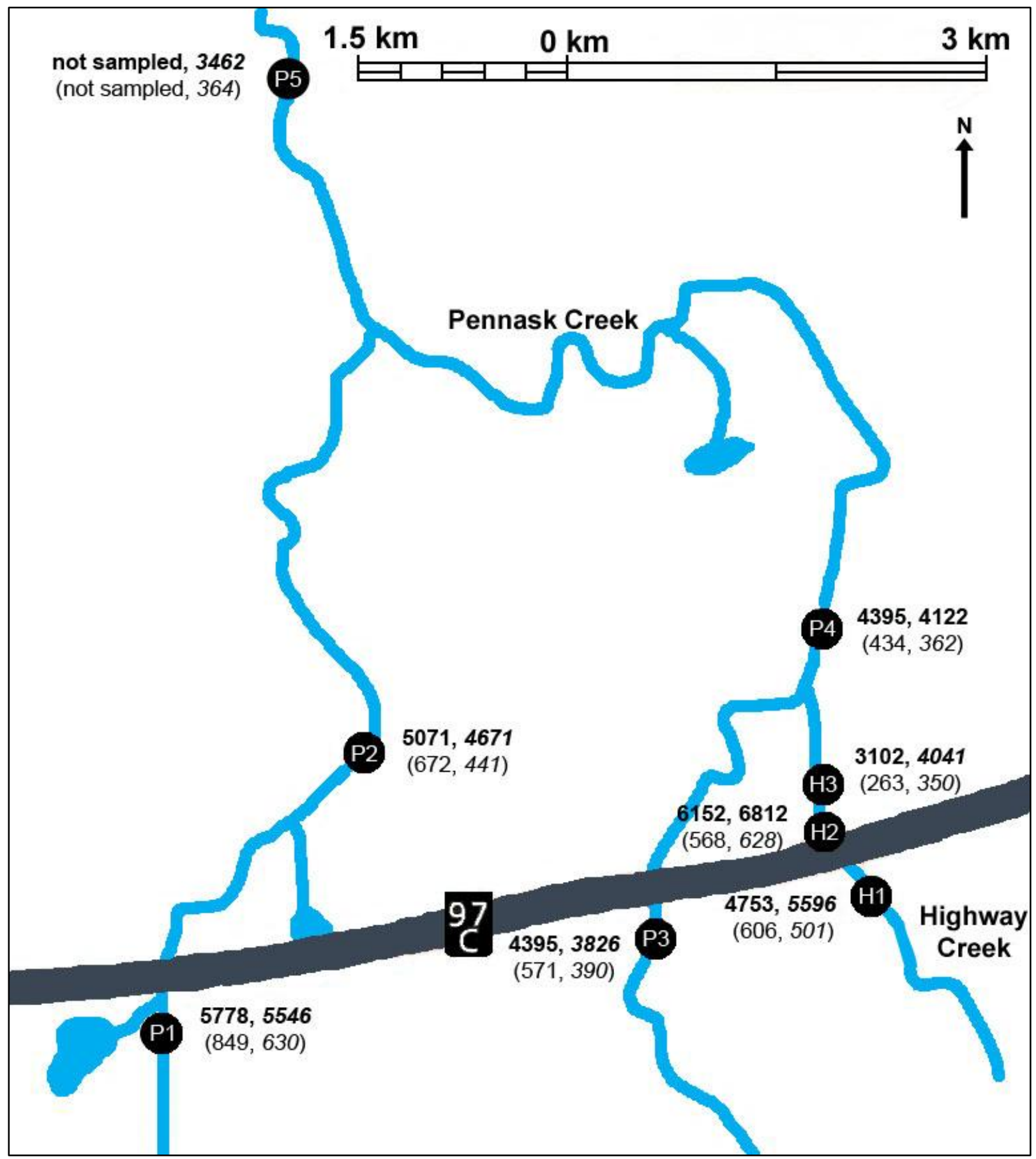

Figure 4.12: Magnesium content $(\mathrm{mg} / \mathrm{kg}$, $\mathrm{dw})$ of sediment samples

$($ bold $=$ total metal content, brackets $=$ extractable metal content, regular text $=$ July, italics $=$ September $)$ 


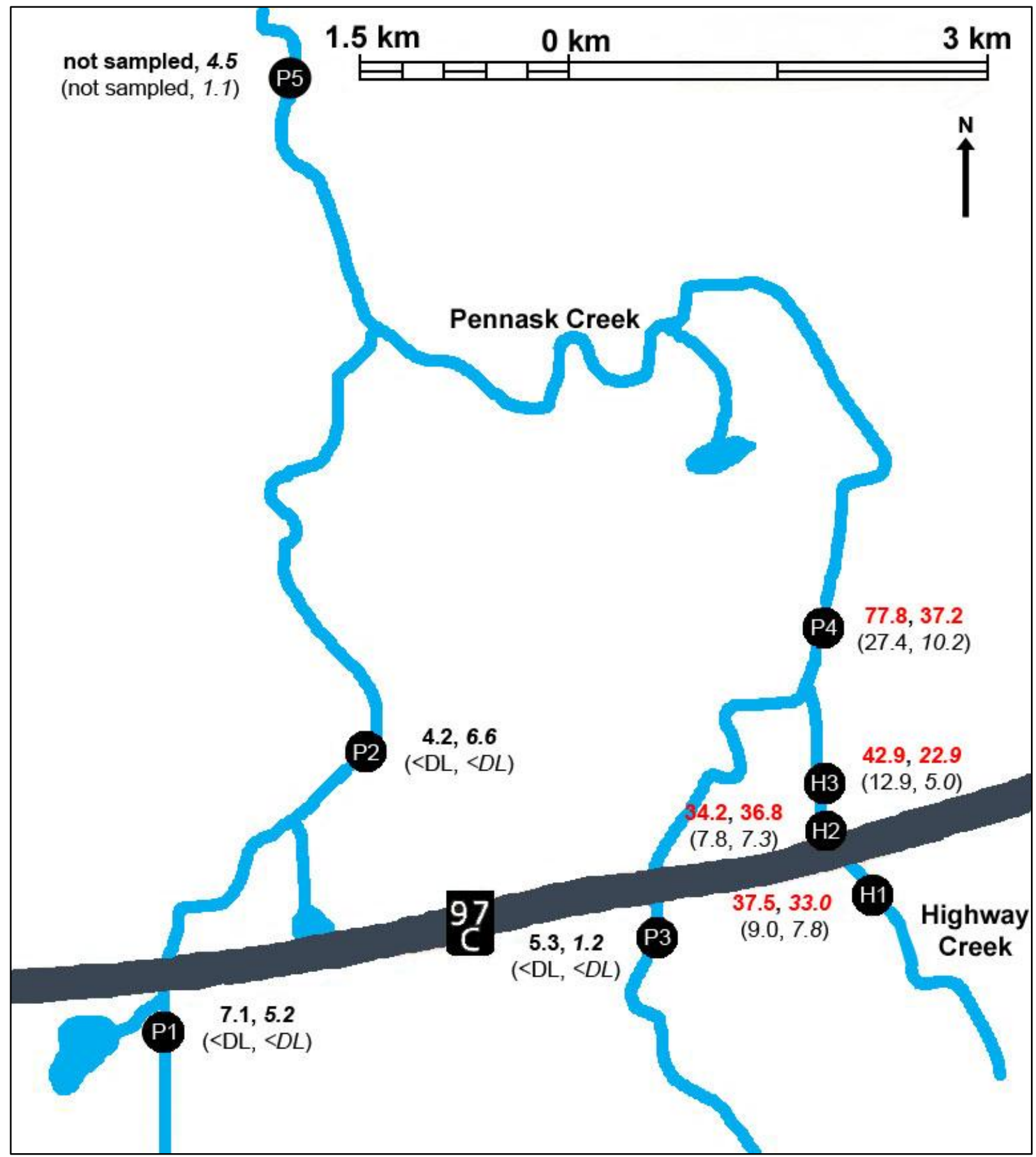

Figure 4.13: Nickel content $(\mathrm{mg} / \mathrm{kg}, \mathrm{dw})$ of sediment samples

(bold $=$ total metal content, brackets $=$ extractable metal content, regular text $=$ July, italics $=$ September; red: exceeds sediment quality guideline; $\angle \mathrm{DL}=$ below detection limits) 


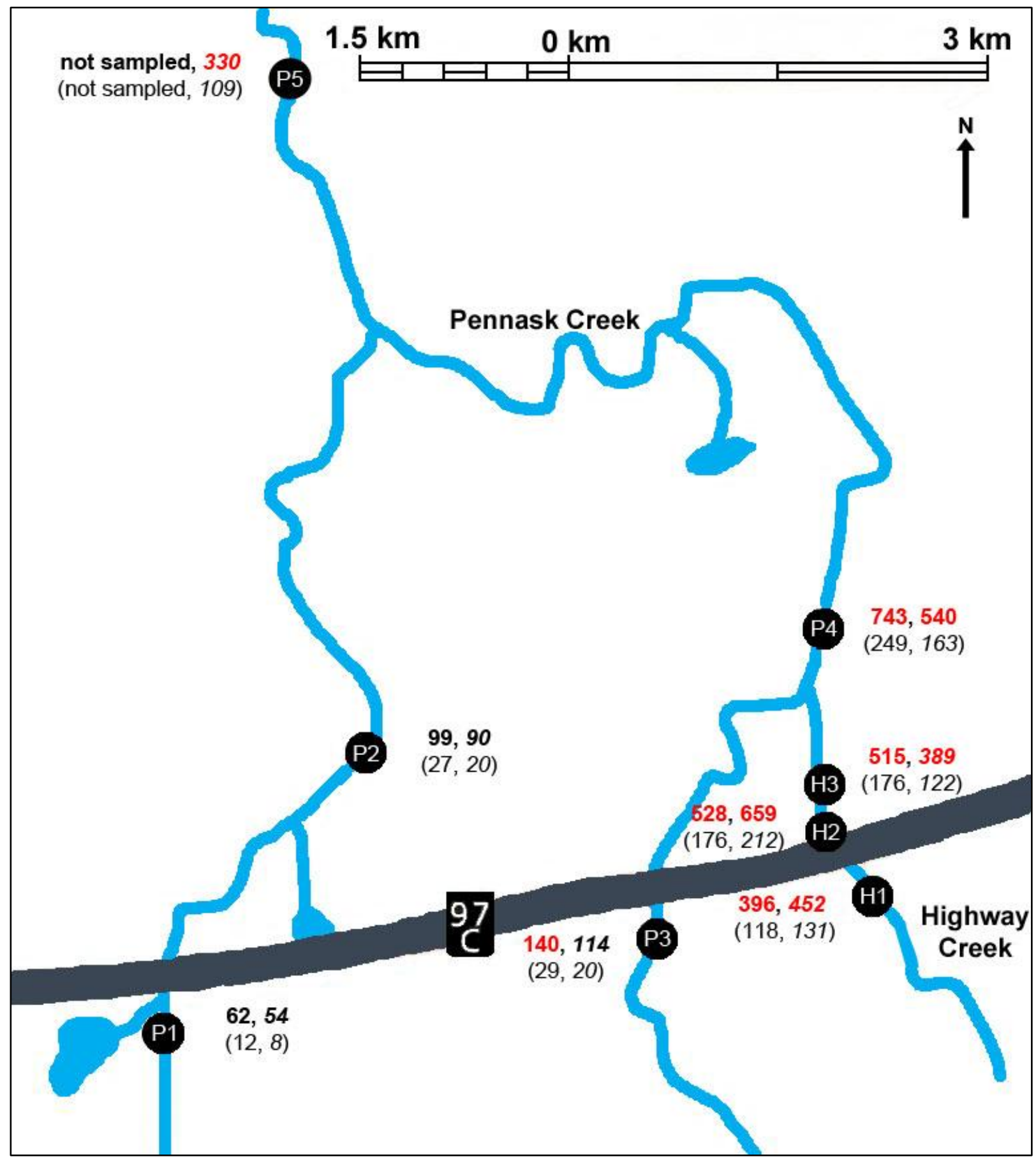

Figure 4.14: Zinc content $(\mathrm{mg} / \mathrm{kg}, \mathrm{dw})$ of sediment samples

(bold $=$ total metal content, brackets $=$ extractable metal content, regular text $=$ July, italics $=$ September; red: exceeds sediment quality guideline) 
Overall, sediment metal contents were higher in Highway Creek than in Pennask Creek. Total $\mathrm{Al}$ and $\mathrm{Cu}$ contents were elevated at sites $\mathrm{H} 2$ and $\mathrm{H} 3$, but decreased downstream of confluence with Pennask Creek. Total As, Ni, and Zn contents were elevated at all Highway Creek sample sites (H1-H3). Generally, the metal content of sediment samples decreased back to approximately background level downstream of the confluence with Pennask Creek. $\mathrm{As}, \mathrm{Cu}, \mathrm{Ni}$, and $\mathrm{Zn}$ levels remained elevated at P4 and levels returned to background by P5, except for $\mathrm{Zn}$ which still remained two to three times higher than background at P5.

As discussed in Chapter 2, there are sediment quality guidelines for the protection of aquatic life that are recommended for use in BC and Canada (Table 2.2). Tables 4.5 and 4.6 show those sites (shaded) where the total metal content in the sediments exceeds either the ISQG or LEL. $\mathrm{As}, \mathrm{Cu}, \mathrm{Fe}, \mathrm{Ni}$, and $\mathrm{Zn}$ exceeded the guideline value at one or more sample sites. In Highway Creek, samples from $\mathrm{H} 1$ sediments exceeded guideline values for $\mathrm{As}, \mathrm{Cu}, \mathrm{Ni}$ and $\mathrm{Zn}$ in July; $\mathrm{H} 2$ exceeded guideline values for $\mathrm{Cu}, \mathrm{Fe}, \mathrm{Ni}$ and $\mathrm{Zn}$ in September; $\mathrm{H} 3$ exceeded guideline values for $\mathrm{As}, \mathrm{Cu}, \mathrm{Ni}$ and $\mathrm{Zn}$ in July and September, and only As in September. In Pennask Creek, samples from P1 and P2 sediments only exceeded guideline values for $\mathrm{Cu}$ and $\mathrm{Fe}$ in September, respectively. P3 exceeded only As (July and September) and Zn (July) guideline values. Site P4, however, exceeded all sediment quality guidelines except Fe in September. Site P5 was not sampled in July and exceeded the ISQG for $\mathrm{Zn}$ in the September sample. The PEL or SEL values are higher than the ISQG or LEL levels and indicate the total metal content at which probable and severe effects would be expected to occur. Zn levels in the sediments exceeded the PEL for H1, H2, H3, P4, and P5 in both July and September. Site P4 exceeded the PEL for As and the SEL for Ni in July.

Tables 4.9 and 4.10 show the proportion of the total metal content that is extractable for July and September samples, respectively. For $\mathrm{Al}, \mathrm{Cu}$, and $\mathrm{Zn}$, the proportions are highest for sites in Highway Creek (namely H2 and H3) as well as site P4 (Pennask Creek, downstream of confluence with Highway Creek). For all other metals, the proportions are relatively consistent between sample sites. 
Table 4.9: Proportion of July total metal content that is extractable

\begin{tabular}{|c|c|c|c|c|c|c|c|}
\multirow{2}{*}{ Metal } & \multicolumn{6}{|c|}{ Proportion of Total Metal Content that is Extractable } \\
\cline { 2 - 8 } & H1 & H2 & H3 & P1 & P2 & P3 & P4 \\
\hline Al & $13 \%$ & $23 \%$ & $24 \%$ & $14 \%$ & $14 \%$ & $16 \%$ & $19 \%$ \\
\hline As & $16 \%$ & $21 \%$ & $18 \%$ & - & - & $15 \%$ & $13 \%$ \\
\hline Ba & $28 \%$ & $17 \%$ & $19 \%$ & $29 \%$ & $31 \%$ & $29 \%$ & $29 \%$ \\
\hline $\mathbf{C o}$ & $32 \%$ & $31 \%$ & $32 \%$ & $23 \%$ & $24 \%$ & $19 \%$ & $37 \%$ \\
\hline $\mathbf{C u}$ & $25 \%$ & $36 \%$ & $37 \%$ & $23 \%$ & $20 \%$ & $24 \%$ & $33 \%$ \\
\hline $\mathbf{F e}$ & $16 \%$ & $16 \%$ & $21 \%$ & $17 \%$ & $19 \%$ & $18 \%$ & $20 \%$ \\
\hline $\mathbf{M g}$ & $13 \%$ & $9 \%$ & $8 \%$ & $15 \%$ & $13 \%$ & $13 \%$ & $10 \%$ \\
\hline $\mathbf{M n}$ & $38 \%$ & $34 \%$ & $35 \%$ & $35 \%$ & $39 \%$ & $34 \%$ & $36 \%$ \\
\hline $\mathbf{N i}$ & $24 \%$ & $23 \%$ & $30 \%$ & - & - & - & $35 \%$ \\
\hline $\mathbf{P b}$ & $32 \%$ & $35 \%$ & $25 \%$ & $100 \%$ & $57 \%$ & $54 \%$ & $33 \%$ \\
\hline $\mathbf{Z n}$ & $30 \%$ & $33 \%$ & $34 \%$ & $19 \%$ & $27 \%$ & $21 \%$ & $33 \%$ \\
\hline
\end{tabular}

- data below detection limit for one or both samples

Table 4.10: Proportion of September total metal content that is extractable

\begin{tabular}{|c|r|r|r|c|c|c|c|c|} 
Metal & \multicolumn{1}{|c|}{ Proportion of Total Metal Content that is Extractable } \\
\cline { 2 - 9 } & H1 & H2 & H3 & P1 & P2 & P3 & P4 & P5 \\
\hline Al & $10 \%$ & $28 \%$ & $30 \%$ & $12 \%$ & $10 \%$ & $14 \%$ & $16 \%$ & $10 \%$ \\
\hline As & $11 \%$ & - & - & - & - & $20 \%$ & $19 \%$ & $0 \%$ \\
\hline $\mathbf{B a}$ & $22 \%$ & $13 \%$ & $16 \%$ & $27 \%$ & $29 \%$ & $17 \%$ & $26 \%$ & $24 \%$ \\
\hline $\mathbf{C o}$ & $1 \%$ & $29 \%$ & $27 \%$ & $19 \%$ & $29 \%$ & $15 \%$ & $31 \%$ & $24 \%$ \\
\hline $\mathbf{C u}$ & $20 \%$ & $32 \%$ & $35 \%$ & $20 \%$ & $19 \%$ & $21 \%$ & $29 \%$ & $24 \%$ \\
\hline $\mathbf{F e}$ & $12 \%$ & $13 \%$ & $14 \%$ & $13 \%$ & $20 \%$ & $15 \%$ & $15 \%$ & $10 \%$ \\
\hline $\mathbf{M g}$ & $9 \%$ & $9 \%$ & $9 \%$ & $11 \%$ & $9 \%$ & $10 \%$ & $9 \%$ & $11 \%$ \\
\hline $\mathbf{M n}$ & $35 \%$ & $32 \%$ & $31 \%$ & $27 \%$ & $35 \%$ & $16 \%$ & $36 \%$ & $32 \%$ \\
\hline $\mathbf{N i}$ & $24 \%$ & $20 \%$ & $22 \%$ & - & - & - & $27 \%$ & $24 \%$ \\
\hline $\mathbf{P b}$ & $22 \%$ & $27 \%$ & - & $57 \%$ & $50 \%$ & $75 \%$ & $50 \%$ & $63 \%$ \\
\hline $\mathbf{Z n}$ & $29 \%$ & $32 \%$ & $31 \%$ & $14 \%$ & $22 \%$ & $17 \%$ & $30 \%$ & $33 \%$ \\
\hline
\end{tabular}

- data below detection limit for one or both samples

\subsection{Rock Analyses}

\subsubsection{Mineralogical composition}

Mineral identification was carried out using the International Centre for Diffraction Database PDF-4 and Search-Match software by Siemens (Bruker). The minerals present in the rock samples are listed in Table 4.11. The results of the qualitative x-ray powder-diffraction analyses are presented in Table 4.12. A sample X-ray diffractogram is included in Appendix C. The rock 
samples collected from the streambed and banks in the Pennask Creek watershed are made up mainly of quartz and plagioclase. The only sulphide mineral present in any of the samples is pyrite $\left(\mathrm{FeS}_{2}\right)$, and this is present in a very small amount in sample H3-B only. It is therefore unlikely that the rocks sampled in the Pennask Creek watershed are contributing to the ARD problem since there is a lack of sulphide minerals in the rocks.

Table 4.11: Ideal formulae of minerals present in Pennask Creek watershed rock samples

\begin{tabular}{|c|c|}
\hline Mineral & Ideal Formula \\
\hline Quartz & $\mathrm{SiO}_{2}$ \\
\hline Cristobalite & $\mathrm{SiO}_{2}$ \\
\hline Plagioclase & $\mathrm{NaAlSi}_{3} \mathrm{O}_{8}-\mathrm{CaAl}_{2} \mathrm{Si}_{2} \mathrm{O}_{8}$ \\
\hline K-Feldspar & $\mathrm{KAlSi}_{3} \mathrm{O}_{8}$ \\
\hline Clinochlore & $\left(\mathrm{Mg}, \mathrm{Fe}^{2+}\right)_{5} \mathrm{Al}\left(\mathrm{Si}_{3} \mathrm{Al}\right) \mathrm{O}_{10}(\mathrm{OH})_{8}$ \\
\hline Biotite/Phlogopite & $\mathrm{K}(\mathrm{Mg}, \mathrm{Fe})_{3}\left(\mathrm{AlSi}_{3} \mathrm{O}_{10}\right)(\mathrm{OH})_{2} / \mathrm{KMg}_{3}\left(\mathrm{AlSi}_{3} \mathrm{O}_{10}\right)(\mathrm{OH}, \mathrm{F})_{2}$ \\
\hline Muscovite & $\mathrm{KAl}_{2}\left(\mathrm{AlSi}_{3} \mathrm{O}_{10}\right)(\mathrm{OH})_{2}$ \\
\hline Actinolite & $\mathrm{Ca}_{2}(\mathrm{Mg}, \mathrm{Fe})_{5} \mathrm{Si}_{8} \mathrm{O}_{22}(\mathrm{OH})_{2}$ \\
\hline Magnesiohornblende, ferroan & $\mathrm{Ca}_{2}\left(\mathrm{Mg}, \mathrm{Fe}^{2+}\right)_{4} \mathrm{Al}\left(\mathrm{AlSi}_{7}\right) \mathrm{O}_{22}(\mathrm{OH}, \mathrm{F})_{2}$ \\
\hline Augite & $(\mathrm{Ca}, \mathrm{Na})(\mathrm{Mg}, \mathrm{Fe}, \mathrm{Al}, \mathrm{Ti})(\mathrm{Si}, \mathrm{Al})_{2} \mathrm{O}_{6}$ \\
\hline Diopside & $\mathrm{CaMgSi}_{2} \mathrm{O}_{6}$ \\
\hline Forsterite & $\mathrm{Mg}_{2} \mathrm{SiO}_{4}$ \\
\hline Magnetite & $\mathrm{Fe}^{2+} \mathrm{Fe}^{3+}{ }_{2} \mathrm{O}_{4}$ \\
\hline Pyrite & $\mathrm{FeS}_{2}$ \\
\hline Dolomite & $\mathrm{CaMg}\left(\mathrm{CO}_{3}\right)_{2}$ \\
\hline Apatite & $\mathrm{Ca}_{5}\left(\mathrm{PO}_{4}\right)_{3}(\mathrm{~F}, \mathrm{Cl}, \mathrm{OH})$ \\
\hline Kaolinite & $\mathrm{Al}_{2} \mathrm{Si}_{2} \mathrm{O}_{5}(\mathrm{OH})_{4}$ \\
\hline Jarosite & $\mathrm{K}_{2} \mathrm{Fe}^{3+}{ }_{6}\left(\mathrm{SO}_{4}\right)_{4}(\mathrm{OH})_{12}$ \\
\hline Franklinite & $\mathrm{Zn}^{2+} \mathrm{Fe}^{3+}{ }_{2} \mathrm{O}_{4}$ \\
\hline Zircon & $\mathrm{ZrSiO}_{4}$ \\
\hline Zunyite & $\mathrm{Al}_{13} \mathrm{Si}_{5} \mathrm{O}_{20}(\mathrm{OH}, \mathrm{F})_{18} \mathrm{Cl}$ \\
\hline Magnesite & $\mathrm{MgCO}_{3}$ \\
\hline Montmorillonite & $(\mathrm{Na}, \mathrm{Ca})_{0.3}(\mathrm{Al}, \mathrm{Mg})_{2} \mathrm{Si}_{4} \mathrm{O}_{10}(\mathrm{OH})_{2} \mathrm{nH}_{2} \mathrm{O}$ \\
\hline
\end{tabular}


Table 4.12: Results of qualitative XRD analyses of Pennask Creek watershed rock samples

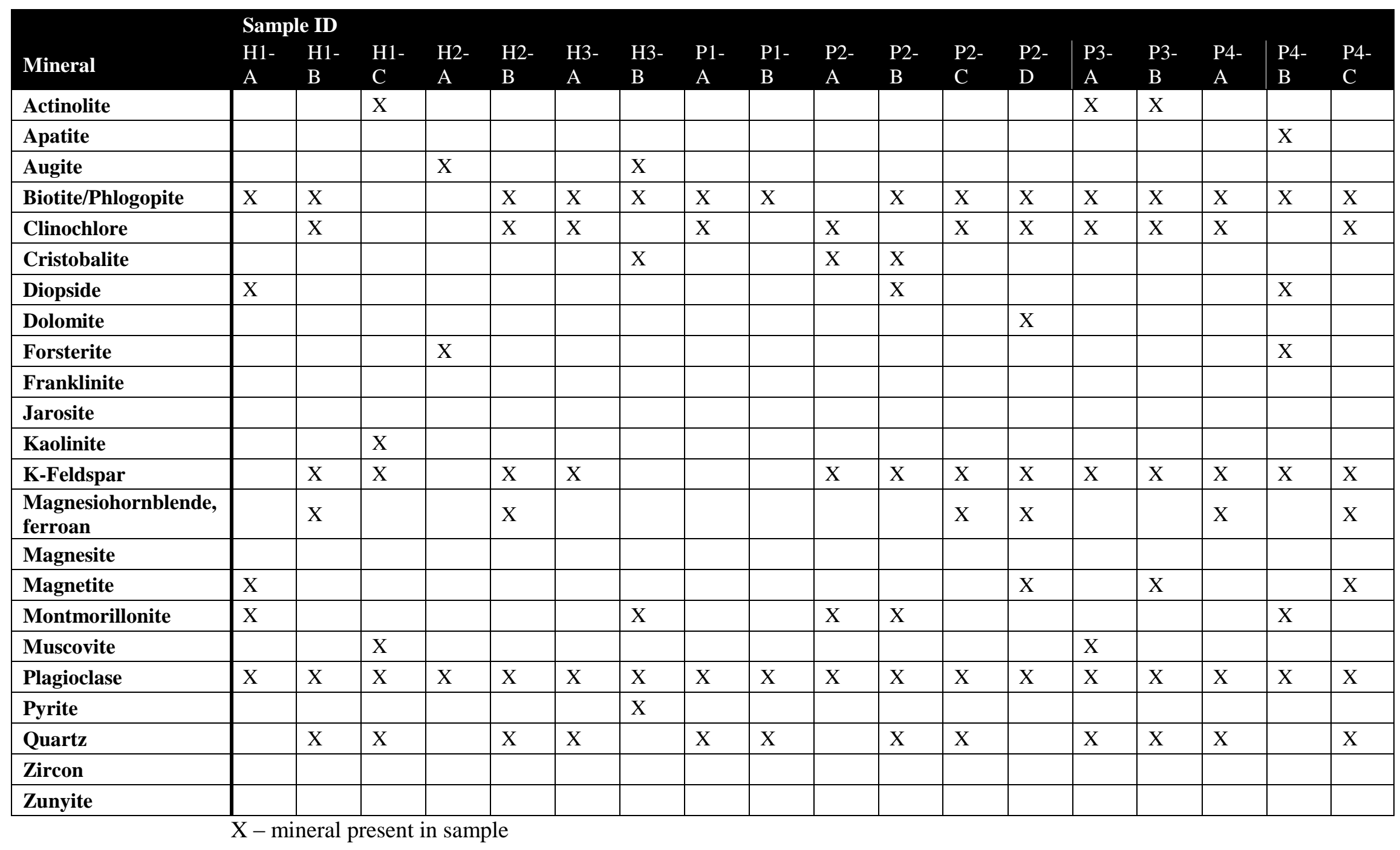




\subsubsection{Chemical composition}

Major (wt. \%) and minor (ppm) element present in Pennask Creek watershed rock samples, as determined by X-ray fluorescence spectrometry, are shown in Table 4.13. Results are corrected for losses on ignition during sample preparation. Precisions, based on repeated re-analysis of international rock standards are better than $\pm 1 \%$ for major elements and better than $\pm 4 \%$ for minor elements. Si was the most plentiful major element present in the rock samples, ranging from $23.99 \%$ to $41.43 \%$ with an average of $29.57 \%$. Al and Fe were the next most plentiful major elements, with average values of $7.84 \%$ and $4.12 \%$, respectively. $\mathrm{Mn}$ and Ba were found in the highest concentration out of the minor elements, with averages of $1009 \mathrm{ppm}$ and 1139 ppm, respectively. Significant levels of $\mathrm{Ca}, \mathrm{Mg}, \mathrm{Na}, \mathrm{V}, \mathrm{Cr}, \mathrm{Ni}, \mathrm{Cu}, \mathrm{Zn}, \mathrm{Rb}, \mathrm{Sr}$, and $\mathrm{Zr}$ were also found in the rock samples. 
Table 4.13: Results of XRF analyses of Pennask Creek watershed rock samples

\begin{tabular}{|c|c|c|c|c|c|c|c|c|c|c|c|c|c|c|c|c|c|c|c|c|c|c|c|c|}
\hline \multirow{2}{*}{$\begin{array}{c}\text { Sample } \\
\text { ID }\end{array}$} & \multicolumn{10}{|c|}{ Major Elements (wt. \%) } & \multicolumn{14}{|c|}{ Minor Elements (ppm) } \\
\hline & $\overline{\mathrm{Si}}$ & $\overline{\mathrm{Al}}$ & $\overline{\mathrm{Fe}}$ & $\mathbf{C a}$ & $\overline{M g}$ & $\mathbf{N a}$ & $\mathbf{K}$ & $\overline{\mathbf{T i}}$ & $\overline{M n}$ & $\overline{\mathbf{P}}$ & $\mathbf{V}$ & $\overline{\mathrm{Cr}}$ & $\overline{M n}$ & $\overline{\mathrm{Co}}$ & $\overline{\mathrm{Ni}}$ & $\overline{\mathbf{C u}}$ & $\mathbf{Z n}$ & $\overline{\mathbf{R b}}$ & $\overline{\mathbf{S r}}$ & $\mathbf{Y}$ & $\mathbf{Z r}$ & $\mathbf{N b}$ & $\mathbf{B a}$ & $\mathbf{P b}$ \\
\hline H1-A & 27.67 & 9.34 & 6.41 & 5.54 & 3.22 & 3.00 & 1.59 & 0.73 & 0.10 & 0.22 & 169 & 253 & 902 & 31 & 88 & 42 & 204 & 30 & 1018 & 17 & 183 & 21 & 1151 & 12 \\
\hline H1-B & 27.42 & 8.47 & 3.91 & 3.38 & 1.24 & 2.81 & 2.14 & 0.36 & 0.11 & 0.09 & 134 & 4 & 1383 & 23 & 9 & 13 & 101 & 71 & 388 & 25 & 108 & 11 & 1307 & 17 \\
\hline $\mathrm{H} 1-\mathrm{C}$ & 33.64 & 8.89 & 0.92 & 0.37 & 0.16 & 3.03 & 4.32 & 0.17 & 0.01 & 0.02 & 44 & 1 & 2 & 6 & 9 & 6 & 24 & 121 & 482 & 20 & 141 & 18 & 1087 & 20 \\
\hline $\mathrm{H} 2-\mathrm{A}$ & 25.86 & 9.81 & 7.00 & 7.06 & 5.17 & 2.49 & 0.37 & 0.92 & 0.11 & 0.09 & 162 & 257 & 1032 & 42 & 175 & 53 & 122 & 5 & 509 & 16 & 87 & 15 & 234 & 8 \\
\hline H2-B & 25.17 & 8.36 & 6.46 & 5.87 & 2.63 & 2.26 & 1.11 & 0.69 & 0.12 & 0.11 & 281 & 94 & 1216 & 33 & 37 & 112 & 102 & 36 & 408 & 23 & 115 & 7 & 294 & 11 \\
\hline H3-A & 41.43 & 2.61 & 1.98 & 0.57 & 0.78 & 0.42 & 0.85 & 0.17 & 0.08 & 0.01 & 108 & 56 & 951 & 16 & 45 & 116 & 171 & 26 & 82 & 14 & 47 & 3 & 804 & 10 \\
\hline H3-B & 24.60 & 7.63 & 4.41 & 4.16 & 2.01 & 2.85 & 2.07 & 0.51 & 0.08 & 0.17 & 157 & 180 & 804 & 24 & 61 & 38 & 134 & 59 & 1042 & 20 & 227 & 22 & 1272 & 17 \\
\hline P1-A & 34.90 & 6.36 & 4.03 & 1.23 & 1.47 & 2.08 & 1.49 & 0.40 & 0.08 & 0.04 & 169 & 80 & 831 & 22 & 33 & 76 & 103 & 38 & 252 & 20 & 123 & 7 & 2813 & 15 \\
\hline P1-B & 36.78 & 5.02 & 2.69 & 1.30 & 1.26 & 1.67 & 1.25 & 0.28 & 0.09 & 0.03 & 114 & 55 & 910 & 16 & 71 & 77 & 150 & 39 & 209 & 29 & 130 & 5 & 1587 & 14 \\
\hline P2-A & 31.69 & 8.39 & 3.00 & 1.95 & 0.45 & 3.44 & 2.55 & 0.51 & 0.02 & 0.09 & 74 & 63 & 188 & 16 & 23 & 40 & 72 & 85 & 490 & 10 & 201 & 16 & 1162 & 15 \\
\hline P2-B & 31.99 & 8.42 & 3.06 & 2.13 & 0.89 & 3.36 & 2.52 & 0.47 & 0.02 & 0.08 & 69 & 41 & 240 & 13 & 26 & 52 & 65 & 83 & 485 & 10 & 196 & 16 & 1200 & 16 \\
\hline P2-C & 27.75 & 7.82 & 2.13 & 2.67 & 0.78 & 3.28 & 1.85 & 0.20 & 0.06 & 0.05 & 83 & 23 & 792 & 13 & 11 & 5 & 60 & 53 & 584 & 10 & 78 & 11 & 1925 & 14 \\
\hline P2-D & 23.99 & 6.54 & 6.17 & 8.60 & 6.00 & 1.57 & 0.73 & 0.36 & 0.13 & 0.14 & 182 & 652 & 1409 & 36 & 121 & 99 & 78 & 15 & 532 & 14 & 56 & 8 & 226 & 9 \\
\hline P3-A & 25.98 & 9.05 & 5.97 & 4.67 & 2.54 & 2.02 & 3.15 & 0.44 & 0.15 & 0.13 & 273 & 56 & 1470 & 33 & 20 & 141 & 111 & 99 & 692 & 20 & 104 & 11 & 1418 & $\overline{14}$ \\
\hline P3-B & 27.07 & 9.64 & 3.47 & 5.95 & 2.49 & 2.32 & 1.51 & 0.45 & 0.15 & 0.20 & 250 & 35 & 1535 & 18 & 20 & 126 & 132 & 57 & 619 & 31 & 122 & 10 & 889 & 16 \\
\hline P4-A & 30.69 & 8.74 & 2.97 & 3.18 & 1.34 & 3.07 & 1.90 & 0.33 & 0.08 & 0.07 & 125 & 69 & 1046 & 16 & 21 & 21 & 82 & 49 & 477 & 12 & 107 & 9 & 1259 & 14 \\
\hline P4-B & 24.33 & 7.04 & 6.79 & 5.91 & 6.37 & 1.90 & 1.86 & 0.60 & 0.22 & 0.20 & 175 & 508 & 2235 & 42 & 181 & 41 & 220 & 71 & 658 & 26 & 128 & 16 & 701 & 14 \\
\hline P4-C & 31.32 & 9.01 & 2.76 & 3.26 & 0.98 & 3.55 & 1.49 & 0.24 & 0.09 & 0.06 & 113 & 26 & 1208 & 14 & 14 & 8 & 85 & 38 & 604 & 12 & 71 & 11 & 1181 & $\overline{14}$ \\
\hline Max. & 41.43 & 9.81 & 7.00 & 8.60 & 6.37 & 3.55 & 4.32 & 0.92 & 0.22 & 0.22 & 281 & 652 & 2235 & 42 & 181 & 141 & 220 & 121 & 1042 & 31 & 227 & 22 & 2813 & 20 \\
\hline Min. & 23.99 & 2.61 & 0.92 & 0.37 & 0.16 & 0.42 & 0.37 & 0.17 & 0.01 & 0.01 & 44 & 1 & 2 & 6 & 9 & 5 & 24 & 5 & 82 & 10 & 47 & 3 & 226 & 8 \\
\hline Mean & 29.57 & 7.84 & 4.12 & 3.77 & 2.21 & 2.51 & 1.82 & 0.43 & 0.09 & 0.10 & 149 & 136 & 1009 & 23 & 54 & 59 & 112 & 54 & 529 & 18 & 123 & 12 & 1139 & 14 \\
\hline SD & 4.85 & 1.80 & 1.89 & 2.36 & 1.87 & 0.81 & 0.93 & 0.20 & 0.05 & 0.07 & 68 & 180 & 531 & 11 & 54 & 44 & 51 & 30 & 241 & 7 & 51 & 5 & 618 & 3 \\
\hline
\end{tabular}




\subsection{Microtox ${ }^{\mathrm{TM}}$ Solid Phase Test}

Table 4.14 shows the results of the Microtox ${ }^{\text {TM }}$ SPT. The certified reference material MESS-3 was tested 6 times to ensure that consistent results could be obtained. The quality control chart is provided in Appendix D. MESS-3 is a contaminated marine sediment and was found to be toxic to the $V$. fischeri bacteria. According to the Environment Canada (2002) reference method for Microtox ${ }^{\mathrm{TM}} \mathrm{SPT}$, if a test sediment has $>20 \%$ fines $(<63 \mu \mathrm{m})$ it is considered to be toxic if the $\mathrm{IC}_{50}$ is $<1000 \mathrm{mg} / \mathrm{L}$. Sediment from H1 and H3 both contain $>20 \%$ fines, but have $\mathrm{IC}_{50}$ values $>1000 \mathrm{mg} / \mathrm{L}$ and are therefore considered not toxic to V. fischeri. Although the Microtox ${ }^{\mathrm{TM}}$ SPT provides only a toxic/not toxic result, the mean $\mathrm{IC}_{50}$ of $\mathrm{H} 3$ is 24 times lower than that of H1. Since H3 sediments are more significantly contaminated with trace metals (Tables $4.5-4.8$ ), it is not surprising that exposure to the $\mathrm{H} 3$ sediments had a greater inhibitory impact on $V$. fischeri. If a test sediment has $<20 \%$ fines, it is considered to be toxic if the $\mathrm{IC}_{50}$ value is < the $\mathrm{IC}_{50}$ value of a negative control sediment with similar fines content and TOC. Sediment from P4 contained only $7.0 \%$ fines, so its' $\mathrm{IC}_{50}$ was compared to that of the negative control sediment, $\mathrm{P} 1$. The mean $\mathrm{IC}_{50}$ of $\mathrm{P} 4$ sediment was $70,666 \mathrm{mg} / \mathrm{L}$ which is three times higher than that of $\mathrm{P} 1$. Therefore, $\mathrm{P} 4$ sediment is not toxic to $V$. fischeri.

Table 4.14: Results of Microtox ${ }^{\mathrm{TM}}$ solid phase test

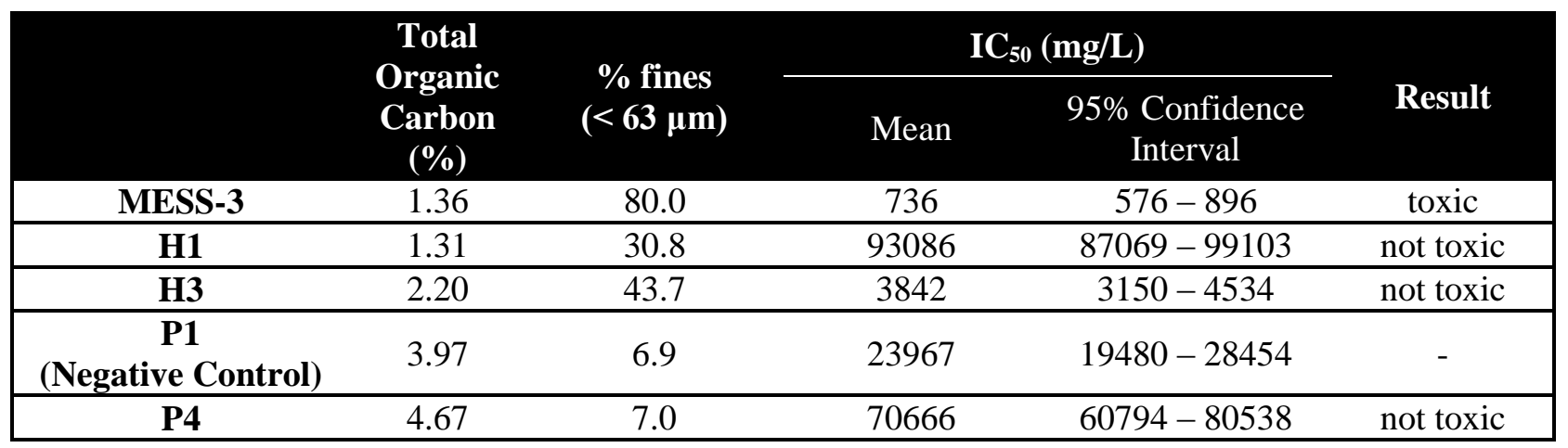

\subsection{Statistical Comparison of July and September Samples}

Conductivity, hardness, temperature, dissolved oxygen, $\mathrm{Cu}$ (total and dissolved), $\mathrm{Fe}$ (total), $\mathrm{Mg}$ (total and dissolved), Mn (total and dissolved) were significantly different $(p \leq 0.05)$ between the July and September water samples. pH, alkalinity, sulphate, turbidity, Al (total and dissolved), $\mathrm{Fe}$ (dissolved), Ni (total and dissolved) and $\mathrm{Zn}$ (total and dissolved) were not significantly 
different in July and September water samples. No significant difference ( $p>0.05)$ was found between July and September sediment samples for $\mathrm{pH}$, total organic carbon, organic matter content, or any metal (total or extractable). Water and sediment Wilcoxon Signed-Rank test $p$ values are shown in Table B1 and B2, respectively, in Appendix B.

\subsection{Variability in Analytical Methodology}

An assessment of some of the laboratory methods was conducted to determine the reliability of the analytical work for both water and sediment samples.

To measure the precision of total metals ICP analysis, the July water samples were analyzed twice, once using the ICP-OES in the UBC Earth and Ocean Sciences department, and once using the ICP-OES in the UBC Environmental Engineering laboratory. The ratio of the maximum: minimum for the two analyses provides a measure of the precision of each metal determination. The ratios for metals that were consistently above analytical detection limits are presented in Table 4.15, while complete data for this analysis are presented in Appendix C (Table C2). The average ratio for twelve duplicate pairs is $\leq 1.25$ for the elements $\mathrm{Al}, \mathrm{Ca}, \mathrm{Co}$, $\mathrm{Cu}, \mathrm{Mg}$ and $\mathrm{Zn}$, indicating good precision of measurement. The precision of measurement for $\mathrm{Fe}, \mathrm{Mn}$ and $\mathrm{Ni}$ is less precise, with average ratios of $1.31,1.37$, and 3.72 respectively.

Table 4.15: Average ratio of duplicate analyses for total metals concentrations by ICP-OES for water samples

\begin{tabular}{|cc|}
\hline Element & $\begin{array}{c}\text { Average Ratio (Maximum: Minimum) } \\
\text { for Twelve Duplicates }\end{array}$ \\
\hline $\mathbf{A l}$ & 1.22 \\
\hline $\mathbf{C a}$ & 1.05 \\
\hline $\mathbf{C o}$ & 1.12 \\
\hline $\mathbf{C u}$ & 1.25 \\
\hline $\mathbf{F e}$ & 1.31 \\
\hline $\mathbf{M g}$ & 1.07 \\
\hline $\mathbf{M n}$ & 1.37 \\
\hline $\mathbf{N i}$ & 3.72 \\
\hline $\mathbf{Z n}$ & 1.03 \\
\hline
\end{tabular}

To obtain a measure of the accuracy and precision of the sediment total metals digestion technique and ICP analysis, four replicate analyses were performed using the marine reference sediment reference material MESS-3 (National Research Council of Canada 2000). The data from these replicate analyses are presented in Table 4.16. All of the mean concentrations for the 
elements are below the reported 95 percent confidence limits. This indicates that complete digestion was not obtained for these elements. The mean value obtained for $\mathrm{Cu}$ is closest to the expected mean (86\%), with $\mathrm{Mn}, \mathrm{Zn}, \mathrm{Pb}$, and $\mathrm{As}$ at 76\%, 72\%, 71\% and 63\%, respectively. Mean values obtained for Co, $\mathrm{Ni}$ and Mo were 57\%, 45\% and 42\% of the expected mean, respectively. Subsequently, the total metal concentrations reported for sediment samples in this study are consistently underestimated (by between $14 \%$ and $58 \%$ ) by the total metals digestion technique utilized. The precision of measurement of all elements measured is good, with the coefficient of variation $(\mathrm{CV})$ ranging from 3.3 to 7.6 percent.

Table 4.16: Measurement of the precision and accuracy of the total metals digestion and ICP technique using the certified reference material MESS-3 (NRC)

$$
(n=4)
$$

\begin{tabular}{|c|c|c|c|c|c|c|c|c|c|}
\hline \multirow[t]{2}{*}{ Element } & Min. & Max. & Median & Mean & \multirow{2}{*}{$\begin{array}{l}\text { CV } \\
(\%)\end{array}$} & $\begin{array}{c}\text { Expected } \\
\text { Mean }\end{array}$ & $\begin{array}{c}95 \% \\
\text { Confidence } \\
\text { Limit } \\
\end{array}$ & \multirow{2}{*}{$\begin{array}{c}\text { Mean/ } \\
\text { Expected } \\
\text { Mean }\end{array}$} & \multirow{2}{*}{$\begin{array}{c}\text { Mean or } \\
\text { Median } \\
\text { within } \\
\text { Expected } \\
\text { Limits }\end{array}$} \\
\hline & \multicolumn{4}{|c|}{ (mg/kg) } & & \multicolumn{2}{|c|}{ (mg/kg) } & & \\
\hline As & 12.65 & 14.50 & 13.12 & 13.35 & 6.3 & 21.2 & 1.1 & 0.63 & $\mathrm{~N}-$ \\
\hline Co & 7.86 & 8.48 & 8.31 & 8.24 & 3.3 & 14.4 & 2.0 & 0.57 & $\mathrm{~N}-$ \\
\hline $\mathrm{Cu}$ & 26.43 & 31.37 & 29.16 & 29.03 & 7.6 & 33.9 & 1.6 & 0.86 & $\mathrm{~N}-$ \\
\hline $\mathbf{P b}$ & 13.88 & 15.50 & 15.22 & 14.95 & 5.1 & 21.1 & 0.7 & 0.71 & $\mathrm{~N}-$ \\
\hline Mn & 235.46 & 253.87 & 250.92 & 247.79 & 3.4 & 324.0 & 12.0 & 0.76 & $\mathrm{~N}-$ \\
\hline Mo & 1.07 & 1.30 & 1.15 & 1.17 & 8.4 & 2.8 & 0.1 & 0.42 & $\mathrm{~N}-$ \\
\hline $\mathbf{N i}$ & 19.54 & 21.91 & 21.49 & 21.11 & 5.3 & 46.9 & 2.2 & 0.45 & $\mathrm{~N}-$ \\
\hline Zn & 108.32 & 117.94 & 115.34 & 114.24 & 3.7 & 159.0 & 8.0 & 0.72 & $\mathrm{~N}-$ \\
\hline
\end{tabular}

\subsection{Variability within Sampling Sites}

In general, only one grab sample was taken at each sampling location. However, three separate water grab samples were taken at two stations (H1B and H3 in July and P3 and P4 in September) to obtain an estimate of the environmental variability within a site. The small local variability within a sample site relative to the variability across all sample sites, as illustrated in Figure 4.15, suggests that a single grab sample from each site can provide accurate information regarding water quality. 


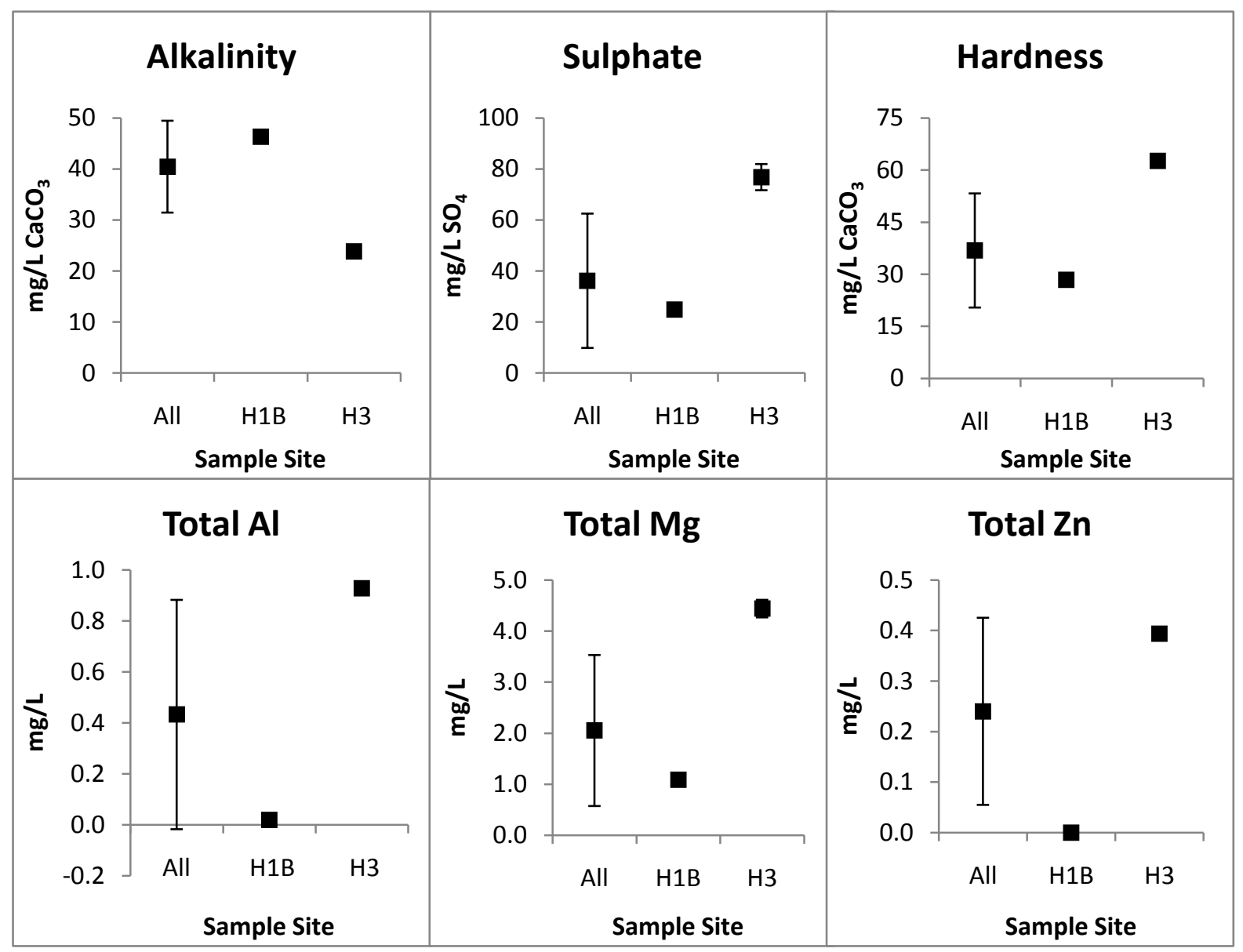

Figure 4.15: Mean and standard deviation of several water quality parameters (July) for all sample sites $(n=8)$ compared to single sample sites H1B and H3 $(n=3)$ 


\section{CHAPTER 5: DISCUSSION}

\subsection{Water Quality}

To obtain a measure of the variability in the water chemistry and metal concentrations in the Pennask Creek watershed, grab samples were collected twice during summer low flow conditions, in July and September 2009. pH, specific conductivity, water temperature, dissolved oxygen, turbidity, total alkalinity, hardness, sulphate, and the concentration of several metals were measured (Appendix B).

No discharge measurements are available for Highway Creek, while no real-time data is available for Pennask Creek. Archived Pennask Creek discharge data for 64 years between 1920 and 2008 are available from Environment Canada's Archived Hydrometric Database (2006) for station 08LG016 in Pennask Creek. The mean monthly discharges for July and September over this 64 year time period were $0.635 \mathrm{~m}^{3} / \mathrm{s}$ and $0.194 \mathrm{~m}^{3} / \mathrm{s}$, respectively. For comparison, the highest discharge in Pennask Creek occurs historically in May and June with mean monthly values of $3.26 \mathrm{~m}^{3} / \mathrm{s}$ and $2.83 \mathrm{~m}^{3} / \mathrm{s}$, respectively.

\subsubsection{Spatial and temporal variability of general water chemistry}

The $\mathrm{pH}$ of Pennask Creek ranged from 6.6 to 7.2, falling within the acceptable $\mathrm{pH}$ range for the protection of aquatic life in BC freshwaters. The $\mathrm{pH}$ of Highway Creek upstream of the ARD source (Site H1) was 7.0, within the same range as that of Pennask Creek. However, at sites in Highway Creek downstream of ARD source (H2 and H3), the $\mathrm{pH}$ values dropped as low as 6.2. This drop in $\mathrm{pH}$ is an indicator that ARD is entering Highway Creek downstream of Highway 97C. No significant temporal variability was found for $\mathrm{pH}$ between July and September 2009.

The total alkalinity measurements showed that site H3 had the lowest value in both July and September (23.9 and $8.6 \mathrm{mg} / \mathrm{L} \mathrm{CaCO}_{3}$, respectively). The drop in alkalinity at $\mathrm{H} 3$ indicates that the acidity entering Highway Creek from the ARD source is being neutralized by the alkalinity of the stream water. Downstream of site H3, Highway Creek flows into Pennask Creek, where both the alkalinity and $\mathrm{pH}$ return to background levels (at site $\mathrm{P} 4$ ). Alkalinity did not show any significant temporal variability between July and September.

Hardness values were elevated at sites in both Highway Creek and Pennask Creek, downstream of the ARD source (sites H2, H3, P4 and P5). The primary ions related to hardness in freshwater 
are $\mathrm{Ca}$ and $\mathrm{Mg}$, however Fe and $\mathrm{Mn}$ may also contribute. This increase in hardness may be due to the input of such ions from the ARD source. Hardness values were slightly higher in September than July, perhaps due to decreased stream flow.

Conductivity values follow a similar spatial trend to that of $\mathrm{pH}$ and alkalinity, with values at sites downstream of the ARD source being higher than those upstream of the ARD source. Sites H2, H3 and P4 show particularly elevated conductivity values (103, 134, $86 \mu \mathrm{S} / \mathrm{cm}$ and 170, 304, 147 $\mu \mathrm{S} / \mathrm{cm}$ in July and September, respectively), compared to background levels ranging from 60 to $76 \mu \mathrm{S} / \mathrm{cm}$ in July and 54 to $128 \mu \mathrm{S} / \mathrm{cm}$ in September. Since conductivity is affected by the presence of inorganic dissolved solids such as sulphate and metal ions, the elevated values at sites H2, H3 and P4 indicate a potential discharge of ARD into Highway Creek. Conductivity values exhibited significant temporal variation between July and September, perhaps due to decreased discharge in September.

Sulphate is produced during the oxidation of sulphide minerals and so is directly related to ARD production. It is unaffected by sorption processes or precipitation and is therefore an excellent indicator for ARD-affected waters (Gray 1996). In both July and September, site H3 had the highest sulphate concentration $(76.8$ and $85.6 \mathrm{mg} / \mathrm{L}$, respectively), indicating a discharge of ARD into Highway Creek. Downstream of the confluence with Pennask Creek, sulphate values return to background level due to dilution. Sulphate did not exhibit significant temporal variation between July and September.

In July, water flowing in Pennask Creek was an average of $5.5^{\circ} \mathrm{C}$ higher than that of Highway Creek. In September, the mean temperatures of the two creeks were approximately equal. For the entire watershed, water temperature values were $40 \%$ lower in September than in July, resulting in a $30 \%$ increase in dissolved oxygen in September compared to July. The temperature difference was most notable in Pennask Creek where the mean temperature decreased by $50 \%$ in September (compared to a $20 \%$ decrease in Highway Creek).

Turbidity values were elevated at sites H2 and H3 (> 2.5 NTU) in both July and September, with values elsewhere in the watershed $(<1.0$ NTU) relatively consistent both spatially and temporally. The elevated turbidity at sites $\mathrm{H} 2$ and $\mathrm{H} 3$ indicates discharge of suspended materials into Highway Creek downstream of the ARD source. 


\subsubsection{Spatial and temporal variability of trace metal concentrations}

Generally, the concentration of metals ( $\mathrm{Al}, \mathrm{Ba}, \mathrm{Co}, \mathrm{Cu}, \mathrm{Fe}, \mathrm{Mg}, \mathrm{Mn}, \mathrm{Ni}$ ) in Highway Creek downstream of Highway 97C (sites H2 and H3) was higher than in Pennask Creek. These results indicate that ARD continues to enter Highway Creek despite the treatment and containment measures being undertaken, perhaps through groundwater seeps.

Aluminum concentrations at sites $\mathrm{H} 2$ and $\mathrm{H} 3$ were one to two orders of magnitude greater than background levels in both July and September. With the exception of site P4 in July, the Al concentrations in Pennask Creek quickly dropped to background levels downstream of the confluence with Highway Creek. The data for P4 in July is an outlier and may be caused by an error in sampling or laboratory analysis. As ARD containing Al enters an uncontaminated stream with neutralizing capacity (such as Highway Creek and Pennask Creek), its pH increases rapidly and the solubility of $\mathrm{Al}$ decreases, resulting in precipitation of aluminum oxides and hydroxides (Brake et al. 2001). This causes a white Al-rich precipitate which was visible both as froth on the water surface and a coating on the channel bottom in Highway Creek. Accordingly, the dissolved $\mathrm{Al}$ concentration in the stream water decreases. Al did not exhibit a significant temporal variation between July and September.

Total and dissolved copper concentrations at sites $\mathrm{H} 2$ and $\mathrm{H} 3$ were elevated above background levels in both July (approximately 1.2 times and 3 times greater for total and dissolved, respectively) and September (approximately 3 times greater for both total and dissolved). Once the flow of Highway Creek enters Pennask Creek, dilution occurs and the $\mathrm{Cu}$ concentration returns to background level by site $\mathrm{P} 4$. Both total and dissolved $\mathrm{Cu}$ concentrations were significantly different between July and September $(\mathrm{p} \leq 0.05)$, with concentrations approximately 45\% lower in September. The lower discharge of Pennask Creek (and likely Highway Creek as well) in September may account for decreased leaching of metals from rocks and soils, and therefore a lower $\mathrm{Cu}$ concentration in the creeks.

Iron followed a similar spatial trend to $\mathrm{Al}$ and $\mathrm{Cu}$, with elevated concentrations at sites $\mathrm{H} 2$ and H3. Sites P4 and P5 also showed concentrations slightly above background. Total Fe concentrations showed significant temporal variation $(\mathrm{p} \leq 0.05)$, with the mean September concentration approximately two times greater than that of July. Dissolved Fe concentrations did not show significant temporal variation. 
Total and dissolved magnesium concentrations were elevated above background levels at sites H2 (approximately two times greater) and H3 (between three and five times greater). Site P2 (west branch of Pennask Creek, north of Highway 97C) also had Mg concentrations higher than background (site P1, same branch of creek, south of highway), with levels $30 \%$ to $72 \%$ greater. Mg concentrations at sites P4 and P5 remained slightly greater than those south of Highway 97C, indicating an input of Mg-rich ARD north of the highway. Both total and dissolved $\mathrm{Mg}$ concentrations were significantly different in July and September $(\mathrm{p} \leq 0.05)$, with September concentrations 1.5 times greater.

Manganese concentrations showed elevation above background at sites H2 and H3 (20 to 30 times), with the concentrations being diluted downstream of the confluence with Pennask Creek. Site P4 still exhibited some enrichment of Mn (approximately 10 times greater than background), but the concentrations had returned to background levels by site P5. Both total and dissolved Mn concentrations showed significant temporal variations $(\mathrm{p} \leq 0.05)$, with September concentrations approximately double those in July.

Nickel was found to be above the detection limit $(0.005 \mathrm{mg} / \mathrm{L})$ only at site $\mathrm{H} 3$ in July and at sites $\mathrm{H} 2$ and H3 in September. Total and dissolved concentrations were very similar at each site, with the concentrations at site $\mathrm{H} 3$ three to four times greater in September than July.

Zinc was detected at sites H2 and H3 in both July and September, with concentrations

exhibiting no significant temporal difference $(\mathrm{p}>0.05)$. Concentrations were approximately two times greater at site $\mathrm{H} 3$ than site $\mathrm{H} 2$. All other sampling stations had $\mathrm{Zn}$ concentrations at least one order of magnitude lower than $\mathrm{H} 2$ and H3, with all except P4 in September $(\sim 0.03 \mathrm{mg} / \mathrm{L})$ below the detection limit of $0.01 \mathrm{mg} / \mathrm{L}$.

\subsubsection{Historical trends}

Historical pH data (BWP Consulting 2000-2009) shows a gradual improvement of the water quality in the Pennask Creek watershed. Figure 5.1 shows a clear convergence in $\mathrm{pH}$ values between water sampling sites since 2005. The $\mathrm{pH}$ at sites $\mathrm{H} 2$ and $\mathrm{H} 3$ has risen markedly, approaching that of site $\mathrm{H} 1$, which is upstream of the ARD source. Figure 5.2 reveals that conductivity has decreased significantly at sites downstream of the ARD source in recent years, with the most noticeable decrease at sites $\mathrm{H} 2$ and $\mathrm{H} 3$ beginning in 2006. These improvements in $\mathrm{pH}$ and conductivity are likely due to the remediation efforts of TRANS. 


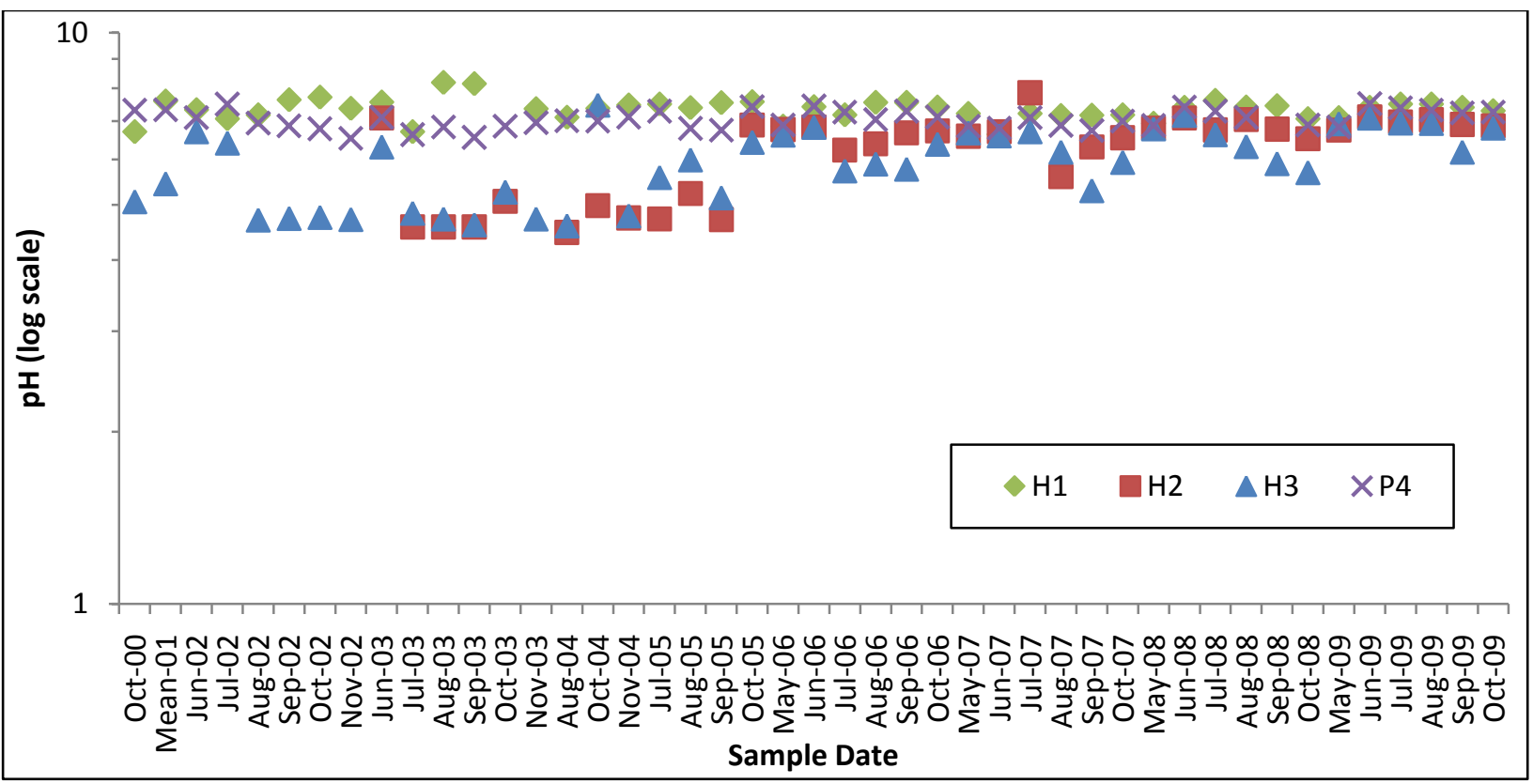

Figure 5.1: pH values in the Pennask Creek watershed (sites H1, H2, H3, P4) from October 2000 to October 2009

(data compiled from BWP Consulting 2000-2009)

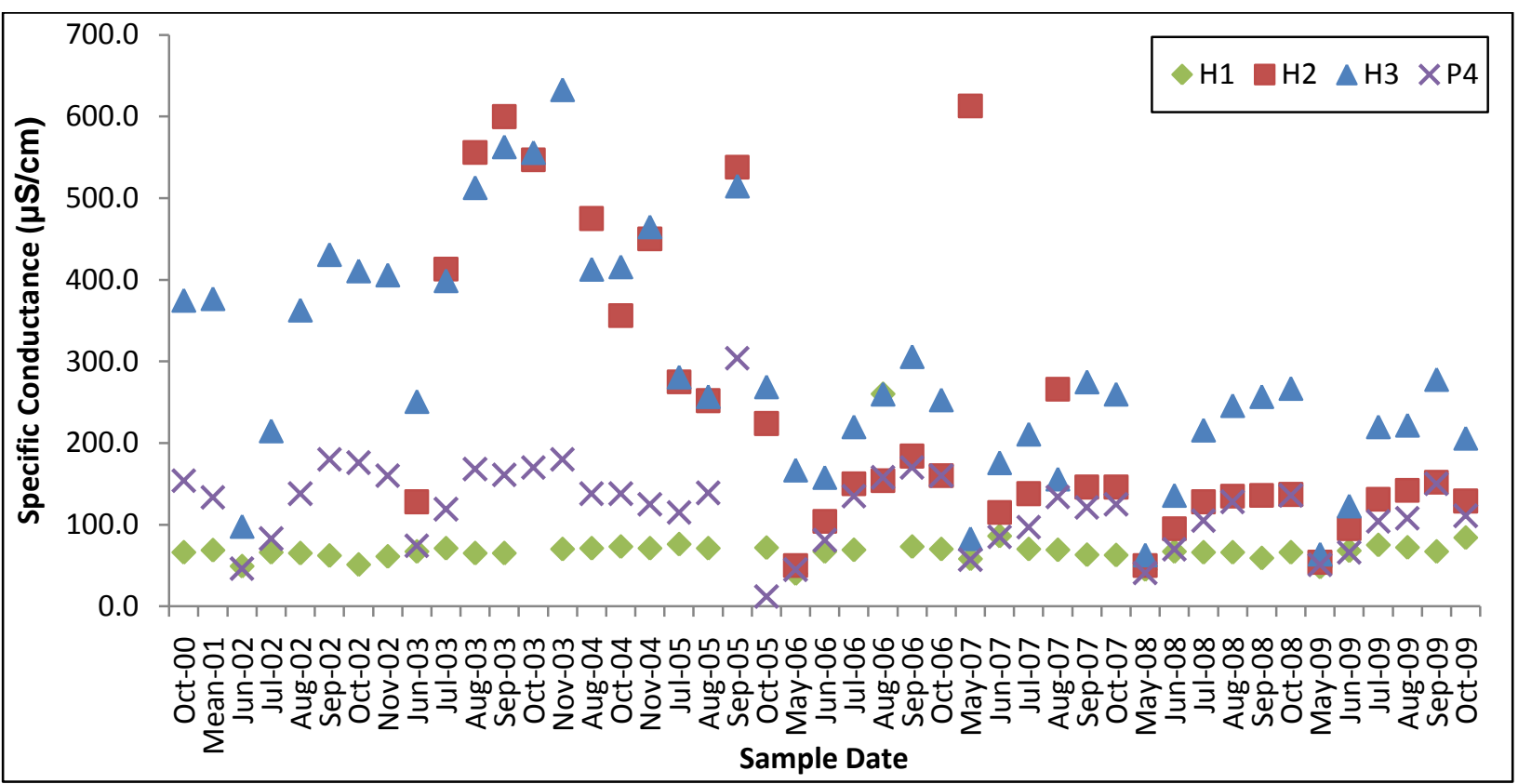

Figure 5.2: Specific conductance values in the Pennask Creek watershed (sites H1, H2, H3, P4) from October 2000 to October 2009

(data compiled from BWP Consulting 2000-2009) 
Figures 5.3 - 5.7 reveal a trend towards decreasing concentrations of metals in both Highway Creek and Pennask Creek from 2004 to 2009, compared to earlier years. Dissolved Al, and total $\mathrm{Cu}, \mathrm{Mn}, \mathrm{Ni}$ and $\mathrm{Zn}$ concentrations have decreased markedly over this time period, most significantly at sites $\mathrm{H} 2$ and $\mathrm{H} 3$. Despite the clear drops in concentration, these metals remain elevated at sites downstream of the ARD source compared to sites elsewhere in the watershed. This indicates that the remediation measures undertaken by TRANS have made a noteworthy difference to the metal concentrations in Highway Creek and Pennask Creek. However, it appears that there continues to be metal-laden drainage seeping into the watershed, perhaps through underground seeps.

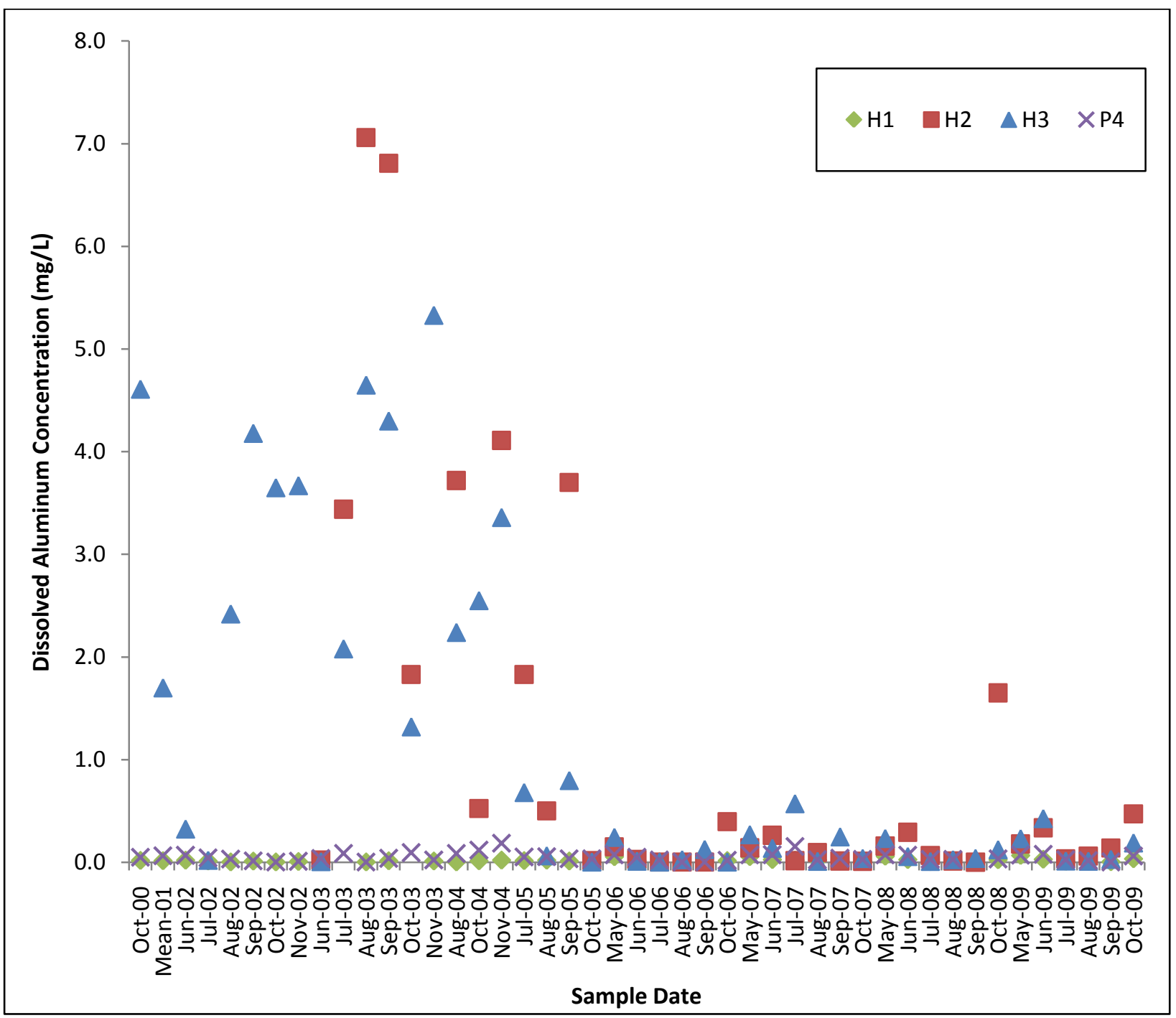

Figure 5.3: Dissolved aluminum concentration in the Pennask Creek watershed (sites H1, H2, H3, P4) from October 2000 to October 2009

(data compiled from BWP Consulting 2000-2009) 


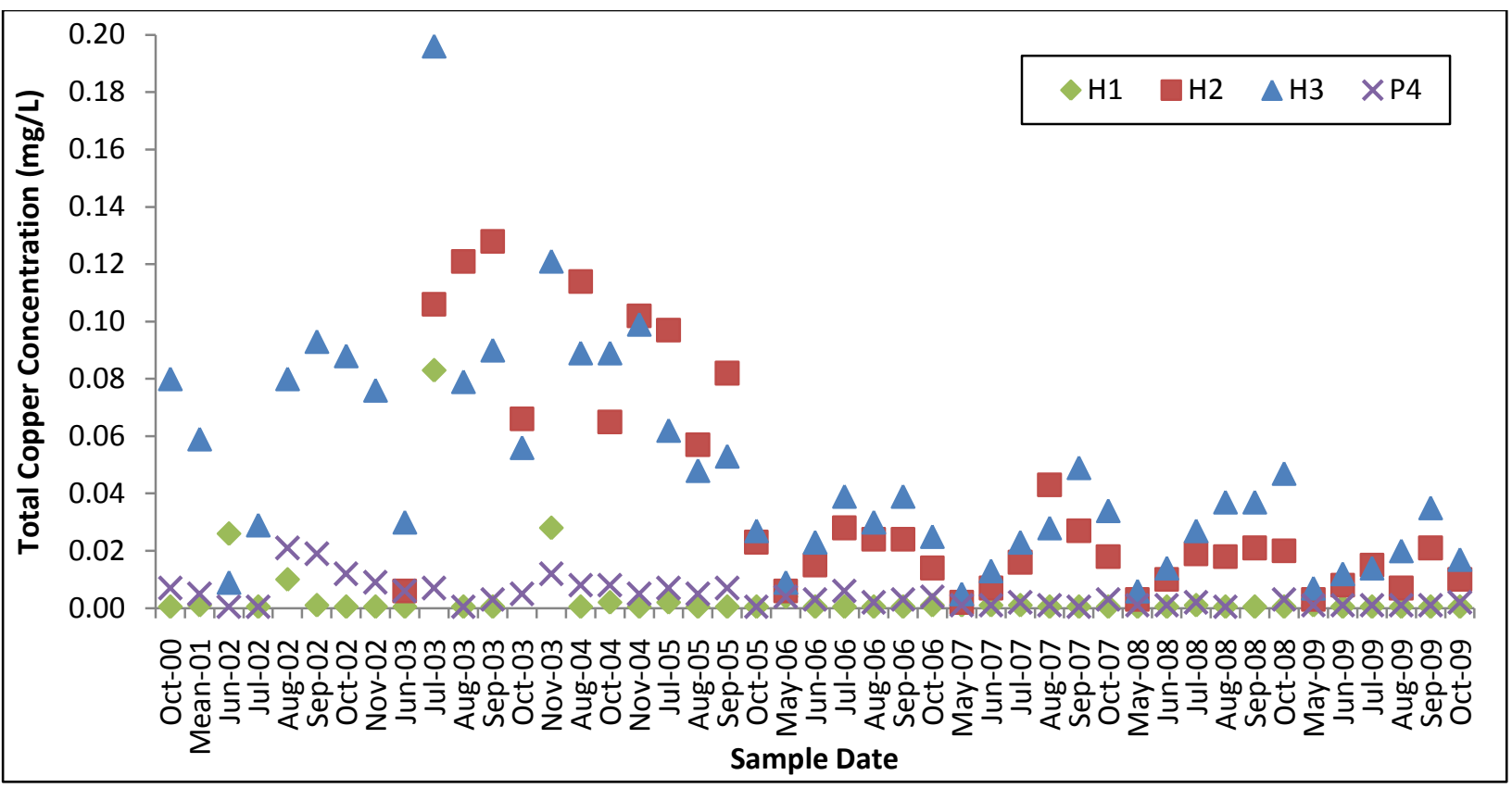

Figure 5.4: Total copper concentration in the Pennask Creek watershed (sites H1, H2, H3, P4) from October 2000 to October 2009

(data compiled from BWP Consulting 2000-2009)

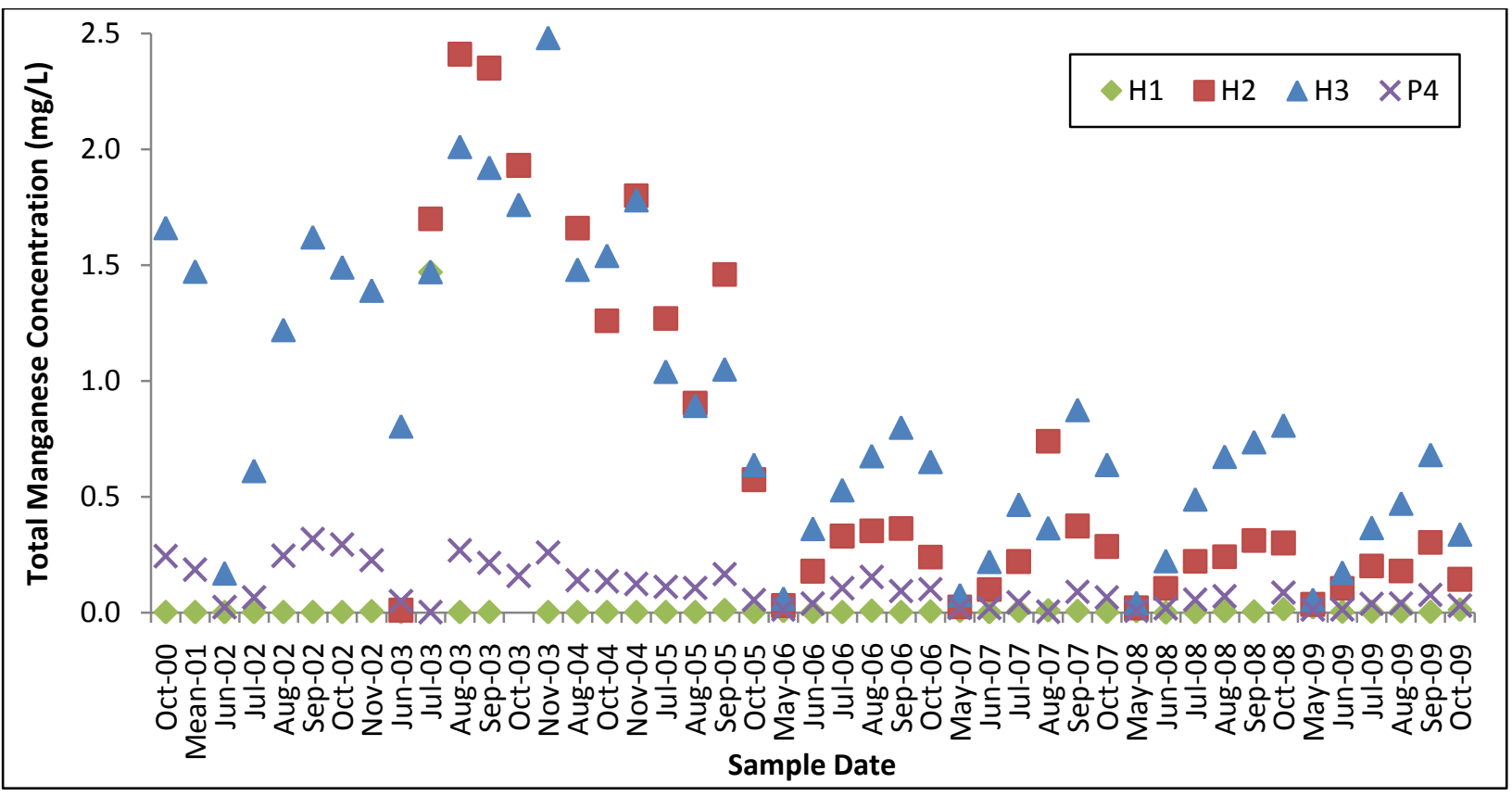

Figure 5.5: Total manganese concentration in the Pennask Creek watershed (sites H1, H2, H3, P4) from October 2000 to October 2009

(data compiled from BWP Consulting 2000-2009) 


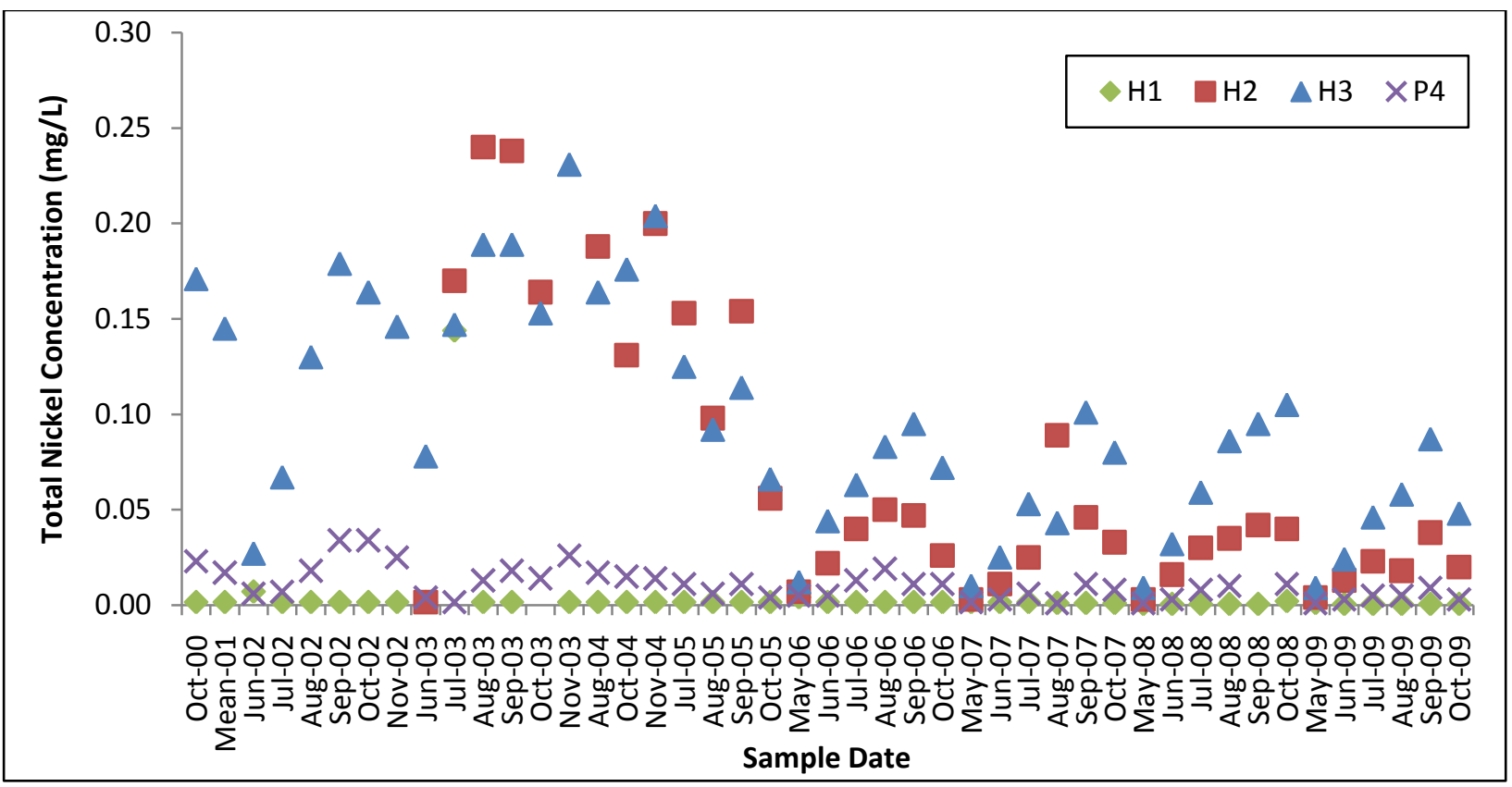

Figure 5.6: Total nickel concentration in the Pennask Creek watershed (sites H1, H2, H3, P4) from October 2000 to October 2009

(data compiled from BWP Consulting 2000-2009)

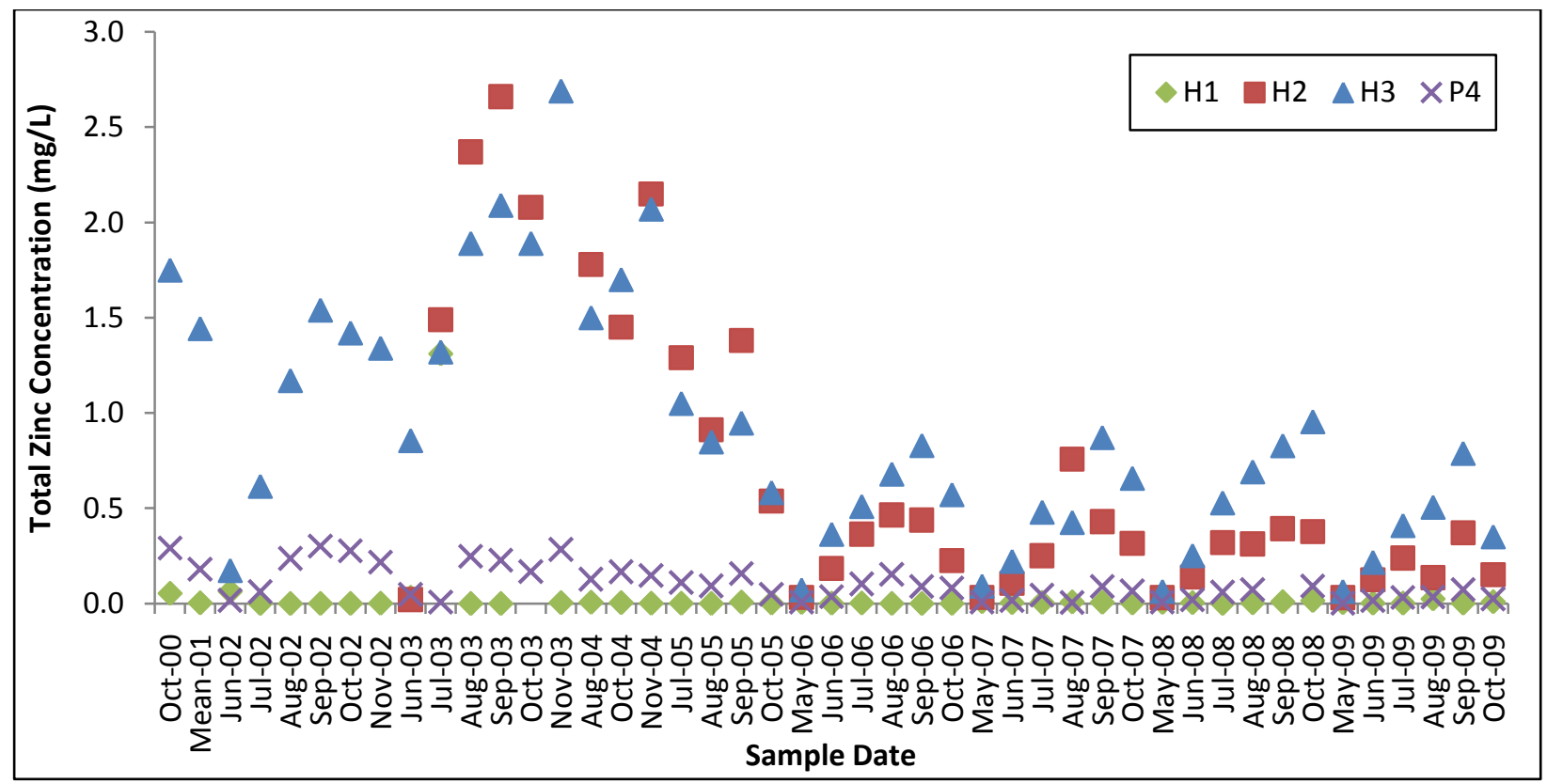

Figure 5.7: Total zinc concentration in the Pennask Creek watershed (sites H1, H2, H3, P4) from October 2000 to October 2009

(data compiled from BWP Consulting 2000-2009) 
Seasonal trends can also be extrapolated from this historical water quality data. $\mathrm{pH}$ appears to be generally higher in the spring and summer and lower in the fall, with a peak in July each year (Figure 5.1). Conductivity was generally lowest in the spring and highest in the fall, with a peak occurring in approximately September each year. Dissolved Al concentrations were generally highest in spring, perhaps correlating with the freshet. Total $\mathrm{Cu}, \mathrm{Mn}, \mathrm{Ni}$, and $\mathrm{Zn}$ concentrations display the opposite seasonal trend, with values lower in the spring and higher in the fall.

\subsubsection{Comparison to other ARD studies}

Water quality results from this study were compared to several other studies found in the literature (Table 5.1). All studies reported on watercourses affected by ARD from mining activities, except for the study by Orndorff and Daniels (2004) which reported on a stream affected by ARD from road construction. When possible, mean data were included for sites both upstream and downstream of the ARD source. For this study, sites H1, P1, P2 and P3 were assigned as 'upstream' sites, while H2, H3, P4 and P5 were considered to be 'downstream' sites. Only dissolved metals concentrations were considered because these were most widely available.

$\mathrm{pH}$ values varied widely across the different studies, with $\mathrm{pH}$ values from this study (6.96 upstream and 6.59 downstream of the ARD source) higher than those cited by Boult et al. (1994), Brake et al. (2001), and McConnell (2002) (6.49/2.4, 8.3/4.92, and 6.36/4.18, respectively). Conductivity values in this study were very similar to those reported by Gray (1996) and McConnell (2002). The other studies did not report conductivity values. Sulphate concentrations for this study were similar to those reported by Gray (1996), several times greater than those reported by McConnell (2002), and lower than those reported by Brake et al. (2001) and DeNicola and Stapleton (2002) (65 times and 5 times lower at the downstream sites, respectively).

Al concentrations in this study were significantly lower than those reported by Boult et al. (1994) and Brake et al. (2001) (90 and 70 times less at downstream sites, respectively), but similar in magnitude to those reported in the other studies. $\mathrm{Cu}$ and Fe concentrations were similar to those reported in other studies except for Boult et al. (1994) and Brake et al. (2001), with values 1000 orders of magnitude greater for $\mathrm{Cu}$ and $\mathrm{Fe}$, and $\mathrm{Fe}$ only, respectively. Mn concentrations were 10 to 50 times lower than those reported by Boult et al. (1994), Brake et al. (2001), DeNicola and Stapleton (2002), and Orndorff and Daniels (2004), but similar to those reported by 
McConnell (2002). Zinc concentrations were approximately 100 times lower than those reported by Brake et al. (2001), but similar to those reported in the other studies. 
Table 5.1: Comparison of water quality data from Pennask Creek watershed to water quality data from ARD-impacted streams in other studies

(mean values are provided unless otherwise noted; dissolved metals concentrations are presented)

\begin{tabular}{|c|c|c|c|c|c|c|c|c|c|c|c|c|c|c|c|}
\hline \multirow[t]{2}{*}{ Parameter } & \multicolumn{2}{|c|}{ This Study } & \multicolumn{2}{|c|}{$\begin{array}{c}\text { Boult et al. } \\
1994\end{array}$} & \multicolumn{2}{|c|}{$\begin{array}{l}\text { Brake et al. } \\
\quad 2001\end{array}$} & \multirow{2}{*}{$\begin{array}{c}\text { DeNicola } \\
\text { and } \\
\text { Stapleton } \\
2002^{(1)}\end{array}$} & \multicolumn{2}{|c|}{$\begin{array}{c}\text { Farag et al. } \\
2007\end{array}$} & \multicolumn{2}{|c|}{$\begin{array}{l}\text { Gray } \\
1996\end{array}$} & \multicolumn{2}{|c|}{$\begin{array}{l}\text { Orndorff and } \\
\text { Daniels } \\
2004\end{array}$} & \multicolumn{2}{|c|}{$\begin{array}{c}\text { McConnell } \\
2002\end{array}$} \\
\hline & $\mathrm{U} / \mathrm{S}$ & $\mathrm{D} / \mathrm{S}$ & $\mathrm{U} / \mathrm{S}$ & $\mathrm{D} / \mathrm{S}$ & $\mathrm{U} / \mathrm{S}$ & $\mathrm{D} / \mathrm{S}$ & & $\mathrm{U} / \mathrm{S}$ & $\mathrm{D} / \mathrm{S}$ & $\mathrm{U} / \mathrm{S}$ & $\mathrm{D} / \mathrm{S}$ & $\mathrm{U} / \mathrm{S}$ & $\mathrm{D} / \mathrm{S}$ & $\mathrm{U} / \mathrm{S}$ & $\mathrm{D} / \mathrm{S}$ \\
\hline $\mathrm{pH}$ & 6.96 & 6.59 & 6.49 & 2.4 & 8.3 & 4.92 & 6.3 & \multicolumn{2}{|c|}{$7.0-8.5^{(2)}$} & 6.8 & 6.1 & 6.6 & 6.7 & 6.36 & 4.18 \\
\hline $\begin{array}{l}\text { Conductivity } \\
(\mu \mathrm{S} / \mathrm{cm})\end{array}$ & 71.3 & 151.7 & - & - & - & - & - & - & - & 78 & 113 & - & - & 34 & 213 \\
\hline $\begin{array}{c}\text { Sulphate } \\
(\mathrm{mg} / \mathrm{L})\end{array}$ & 20.2 & 47.8 & - & - & 38.5 & 3125.5 & 255 & - & - & 6 & 28 & - & - & 0.21 & 16.1 \\
\hline $\begin{array}{c}\text { Hardness } \\
\left(\mathrm{mg} / \mathrm{L} \mathrm{CaCO}_{3}\right)\end{array}$ & 26.7 & 52.3 & - & - & - & - & - & 52 & 65 & - & - & - & - & - & - \\
\hline $\begin{array}{c}\mathrm{Al} \\
(\mathrm{mg} / \mathrm{L})\end{array}$ & 0.06 & 0.59 & 0.12 & 55.56 & 0.01 & 41.1 & 0.10 & - & - & - & - & 0.2 & $<0.1$ & 0.083 & 0.949 \\
\hline $\begin{array}{c}\mathrm{Cd} \\
(\mathrm{mg} / \mathrm{L})\end{array}$ & $<0.001$ & $<0.001$ & & - & $<0.01$ & 0.01 & - & 0.00012 & 0.00342 & 0 & 0.001 & - & - & - & - \\
\hline $\begin{array}{c}\mathrm{Cu} \\
(\mathrm{mg} / \mathrm{L})\end{array}$ & 0.01 & 0.02 & 0.67 & 19.23 & - & - & - & 0.0014 & 0.0198 & 0.01 & 0.03 & $<0.1$ & $<0.1$ & 0.0001 & 0.254 \\
\hline $\begin{array}{c}\mathrm{Fe} \\
(\mathrm{mg} / \mathrm{L})\end{array}$ & 0.07 & 0.16 & 0.15 & 193.24 & 1.0 & 126.5 & 0.40 & - & - & 0.11 & 0.61 & $<0.1$ & $<0.1$ & 0.269 & 1.994 \\
\hline $\begin{array}{c}\mathrm{Mg} \\
(\mathrm{mg} / \mathrm{L})\end{array}$ & 1.39 & 3.29 & - & - & 24.5 & 80.5 & - & - & - & - & - & - & - & 0.76 & 2.98 \\
\hline $\begin{array}{c}\mathrm{Mn} \\
(\mathrm{mg} / \mathrm{L})\end{array}$ & 0.007 & 0.245 & 0.06 & 10.8 & 0.10 & 2.68 & 4.10 & - & - & - & - & 0.5 & 3.6 & 0.016 & 0.581 \\
\hline $\begin{array}{c}\mathrm{Ni} \\
(\mathrm{mg} / \mathrm{L})\end{array}$ & $<0.05$ & $<0.05$ & - & - & $<0.01$ & 0.06 & - & - & - & - & - & - & - & 0.0001 & 0.0107 \\
\hline $\begin{array}{c}\mathrm{Pb} \\
(\mathrm{mg} / \mathrm{L})\end{array}$ & $<0.02$ & $<0.02$ & - & - & $<0.02$ & $<0.02$ & - & $<0.001$ & $<0.001$ & - & - & - & - & 0.0001 & 0.0021 \\
\hline $\begin{array}{c}\mathrm{Zn} \\
(\mathrm{mg} / \mathrm{L})\end{array}$ & $<0.01$ & 0.28 & 0.23 & 30.03 & 0.02 & 0.17 & 0.07 & 0.0017 & 0.5013 & 0.05 & 0.58 & $<0.1$ & $<0.1$ & 0.0001 & 0.500 \\
\hline $\begin{array}{l}\mathrm{U} / \mathrm{S} \\
\mathrm{D} / \mathrm{S} \\
- \\
(1) \\
(2)\end{array}$ & $\begin{array}{l}\text { Upstream } \\
\text { Downstrea } \\
\text { No data av } \\
\text { Data are } \\
\text { pH range }\end{array}$ & $\begin{array}{l}\text { f ARD s } \\
\text { m of AR } \\
\text { ailable } \\
\text { edian va } \\
\text { or all sit }\end{array}$ & $\begin{array}{l}\text { urce } \\
\text { source } \\
\text { es } \\
\text { (not re }\end{array}$ & orted se & arately & & & & & & & & & & \\
\hline
\end{tabular}




\subsection{Sediment Quality}

To obtain a measure of the variability in stream sediment physical and chemical properties in the Pennask Creek watershed, composite sediment samples were collected in July and September 2009. Sediment $\mathrm{pH}$, organic matter content, total organic carbon, total (strong acid) metal content, and (weak acid) extractable metal content were determined (Appendix A).

\subsubsection{Spatial variability of general sediment properties}

The $\mathrm{pH}$ of sediment samples throughout the watershed ranged from 5.5 to 6.5 . The sediment $\mathrm{pH}$ (5.8) at sites $\mathrm{H} 2$ and $\mathrm{H} 3$ was lower than that of the upstream Highway Creek H1 site (6.5), indicating potential effects due to ARD. Sites P1, P2, P3 and P5 in Pennask Creek had relatively consistent sediment $\mathrm{pH}$ (5.5-6.0), with that at $\mathrm{P} 4$ being highest (6.4).

The percentage of fine particles $(<63 \mu \mathrm{m})$ in the $<2 \mathrm{~mm}$ fraction of sediment samples varied widely $(1.1 \%-31.4 \%)$, with sites $\mathrm{H} 1$ and $\mathrm{H} 3$ having the highest values. Sediment samples were composited from several grab samples collected from locations at each sample site that were considered most likely to accumulate fine particles. Therefore, these composite samples are not representative of all sediments at each site, but only those in specific areas.

The organic matter content (determined by loss on ignition) and total organic carbon did not show any clear spatial trend.

\subsubsection{Spatial variability of sediment metal content}

Sediment total $\mathrm{Al}$ and $\mathrm{Cu}$ contents were elevated at sites $\mathrm{H} 2$ and $\mathrm{H} 3$, indicating enrichment from the ARD source. Downstream of the confluence with Pennask Creek, the total Al content returned to background level, while $\mathrm{Cu}$ remained elevated at site $\mathrm{P} 4$. Total $\mathrm{Ni}$ and $\mathrm{Zn}$ are elevated at all sites in Highway Creek and remain elevated at site P4. At site P5, only total Zn content remained elevated above background level. This indicates $\mathrm{Zn}$ contamination of sediments in Pennask Creek due to contamination from Highway Creek, persisting a great distance from the source. The total As content of sediments in the east branch of Pennask Creek (P3, P4) and all of Highway Creek (H1, H2, H3) was noticeably higher ( six times) than in the west branch of Pennask Creek or site P5 near the outflow to Pennask Lake. This may be due to the specific local geology of this subsection of the watershed. Site $\mathrm{H} 2$ had a total Fe content that appears elevated above that of all other sites. This could be due to the decreased solubility of 
aqueous Fe in the ARD as it enters the near-neutral Highway Creek and the resulting precipitation of iron oxides and hydroxides, which likely coat the stream bottom (Brake et al. 2001). Total Mg content exhibits the same spatial pattern as Fe, with the level at site $\mathrm{H} 2$ greater than all other sample sites.

For $\mathrm{Al}, \mathrm{Cu}$, and $\mathrm{Zn}$, the proportion of total metal content that was easily extractable (weak acid) is highest for sites $\mathrm{H} 2, \mathrm{H} 3$ and $\mathrm{P} 4$. This spatial pattern indicates an enrichment of potentially bioavailable $\mathrm{Al}, \mathrm{Cu}$ and $\mathrm{Zn}$ in sediments located downstream of the Highway 97C ARD source.

\subsubsection{Temporal variability of sediment parameters}

No significant temporal difference $(p>0.05)$ was found for any sediment parameter between July and September samples. No previous research regarding sediment quality in the Pennask Creek watershed was available for temporal comparison.

\subsubsection{Comparison to other ARD studies}

Sediment total metals content data from this study were compared to that in several other studies found in the literature (Table 5.2). All studies from the literature reported on watercourses affected by ARD from mining activities. When possible, mean data were included for sites both upstream and downstream of the ARD source. For this study, sites H1, P1, P2 and P3 were assigned as 'upstream' sites, while H2, H3, P4 and P5 were considered to be 'downstream' sites. Although the data presented for each study is 'total metals content', the sediment digestion methods used in each study varied widely. Farag et al. (1998) carried out the total metals extraction using $\mathrm{HNO}_{3}, \mathrm{HCl}$ and $\mathrm{H}_{2} \mathrm{O}_{2}$ with microwave digestion, while Farag et al. (2007) used a warm $2 \mathrm{M} \mathrm{HCl}$ and $1 \% \mathrm{H}_{2} \mathrm{O}_{2}$ digestion, Galán et al. (2003) used a 10:3:2:5 $\mathrm{HF} / \mathrm{HNO}_{3} / \mathrm{HCl} / \mathrm{HClO}_{4}$ heated digestion, Kimball et al. (1995) used a $\mathrm{HNO}_{3} / \mathrm{HF} / \mathrm{HClO}_{4}$ digestion. Soucek et al. (2000a) used a method most similar to that of this study: $50 \%$ (v/v) $\mathrm{HNO}_{3}$ and $20 \%(\mathrm{v} / \mathrm{v}) \mathrm{HCl}$ digesting with reflux heating. The range of techniques utilized to extract the metals makes direct comparisons difficult because each has the potential to extract metals from different geochemical fractions of the sediments and to extract the 'total' metals to different extents. 
Table 5.2: Comparison of sediment total metals content data from Pennask Creek watershed to data from ARD-impacted streams in other studies

(mean values are presented)

\begin{tabular}{|c|c|c|c|c|c|c|c|c|c|c|}
\multirow{2}{*}{ Parameter } & \multicolumn{2}{|c|}{ This Study } & \multicolumn{2}{c|}{$\begin{array}{c}\text { Farag et al. } \\
1998\end{array}$} & \multicolumn{2}{c|}{$\begin{array}{c}\text { Farag et al. } \\
2007\end{array}$} & $\begin{array}{c}\text { Galán } \\
\text { et al. } \\
2003\end{array}$ & $\begin{array}{c}\text { Kimball } \\
\text { et al. } \\
1995\end{array}$ & \multicolumn{2}{c|}{$\begin{array}{c}\text { Soucek et al. } \\
2000 \mathrm{a}\end{array}$} \\
\cline { 2 - 13 } & $\mathrm{U} / \mathrm{S}$ & $\mathrm{D} / \mathrm{S}$ & $\mathrm{U} / \mathrm{S}$ & $\mathrm{D} / \mathrm{S}$ & $\mathrm{U} / \mathrm{S}$ & $\mathrm{D} / \mathrm{S}$ & $\mathrm{D} / \mathrm{S}$ & $\mathrm{D} / \mathrm{S}$ & $\mathrm{U} / \mathrm{S}$ & $\mathrm{D} / \mathrm{S}$ \\
\hline $\mathrm{Al}(\mathrm{mg} / \mathrm{kg})$ & 16152 & 16808 & - & - & - & - & - & - & 5080 & 4562 \\
\hline $\mathrm{As}(\mathrm{mg} / \mathrm{kg})$ & 7.1 & 7.8 & 7.0 & 91.1 & 14 & 257 & 864 & - & - & - \\
\hline $\mathrm{Cd}(\mathrm{mg} / \mathrm{kg})$ & $<0.05$ & $<0.05$ & 0.6 & 37.3 & $<1$ & 4.7 & 5.4 & - & - & - \\
\hline $\mathrm{Cu}(\mathrm{mg} / \mathrm{kg})$ & 31.6 & 119.9 & 27 & 116 & 12 & 183 & 1070 & 227 & 11.0 & 8.4 \\
\hline $\mathrm{Fe}(\mathrm{mg} / \mathrm{kg})$ & 17368 & 21330 & - & - & - & - & - & - & 25.9 & 40.7 \\
\hline $\mathrm{Mn}(\mathrm{mg} / \mathrm{kg})$ & 1024 & 1190 & - & - & - & - & - & 1929 & 956 & 472 \\
\hline $\mathrm{Ni}(\mathrm{mg} / \mathrm{kg})$ & 12.5 & 36.6 & - & - & - & - & 36.8 & - & - & - \\
\hline $\mathrm{Pb}(\mathrm{mg} / \mathrm{kg})$ & 1.61 & 3.32 & 90 & 3755 & 16 & 282 & 843 & 529 & - & - \\
\hline $\mathrm{Zn}(\mathrm{mg} / \mathrm{kg})$ & 164 & 529 & 339 & 5903 & 71 & 922 & 1680 & 4212 & 48.9 & 61.7 \\
\hline
\end{tabular}

Soucek et al. (2000a), the only other study that reported total Al content of sediments, had results approximately three times lower than those in the Pennask Creek watershed. As content in this study was similar to the upstream sites reported in Farag et al. (1998), but downstream As content was between 11 and 100 times lower than in the other studies. Total sediment Cd was below detection limits in this study and therefore appreciably lower than those reported in the other studies. Cu content was very similar to those reported by Farag et al. (1998 and 2007), two times lower than those in Kimball et al. (1995), nine times lower than those in Galán et al.

(2003), and 14 times lower than the downstream sites in Soucek et al. (2000a). Fe content in this study was considerably greater (three orders of magnitude) than those reported by Soucek et al. (2000a), the only other study to report Fe content. Mn content was in a similar range as those reported by Kimball et al. (1995) and Soucek et al. (2000a). Galán et al. (2003) was the only other study to report $\mathrm{Ni}$ content and the values were similar to those in this study. Sediment $\mathrm{Pb}$ content in the Pennask Creek watershed was between 100 and 1000 times lower than in the other studies listed in Table 5.2. Zn content in this study was in the same order of magnitude as those reported by Farag et al. (2007), between three and ten times lower than those reported by Farag et al. (1998), Galán et al. (2003) and Kimball et al. (1995), and nine times greater than those reported by Soucek et al. (2000a). 


\subsection{Biological Impacts}

\subsubsection{Benthic macroinvertebrate monitoring}

Benthic macroinvertebrate monitoring provides a good indicator of environmental quality. Such organisms are good indicators of localized conditions because they generally have limited migration patterns (if any). Benthic macroinvertebrate assemblages are made up of species that constitute a broad range of trophic levels and pollution tolerances, thus providing strong information for interpreting cumulative effects. These organisms serve as a primary food source for fish, including rainbow trout, and as such provide a good indication of the quality of fish habitat in the Pennask Creek watershed.

Historical benthic invertebrate data (BWP Consulting 2000-2009) shows that, in general, the abundance and diversity of invertebrates living in the Pennask Creek watershed is relatively consistent. The total number of benthic macroinvertebrates captured at each site from 20002009 is presented in Figure 5.8. Total abundance was lowest at sites downstream of the Highway 97C ARD source (H2, H3, and P4) compared to the site upstream of the ARD source (H1). The total abundance at site P5, which is at a great distance from the confluence of Highway and Pennask Creeks, is markedly higher than at the other sites. This is likely due to good water quality combined with reduced canopy cover in the area, which allows more sunlight into the creek thus supporting a greater abundance of aquatic macrophytes and thus benthic invertebrates. The total abundance of invertebrates appears to have increased at site P4 to a level similar to or greater than site H1 since 2007. This could signify improved habitat quality and the re-establishment of the benthic invertebrate community downstream of the confluence of Highway and Pennask Creeks. The abundance of invertebrates at sites H2 and H3 remains low, probably due to low habitat quality, including poor water and sediment quality along with considerable mineral deposits coating the stream substrate at these locations. 


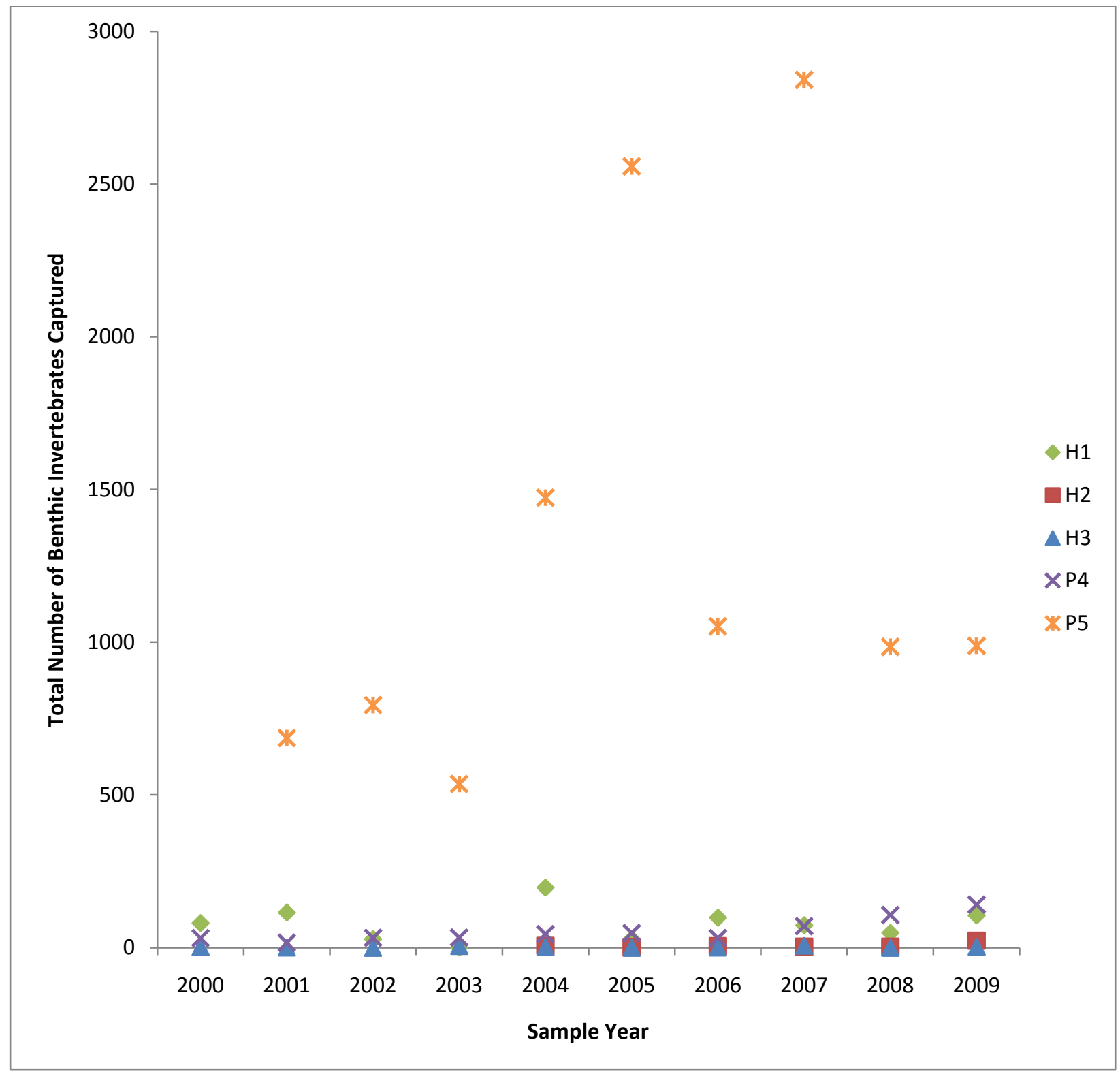

Figure 5.8: Total number of benthic macroinvertebrates captured in the Pennask Creek watershed (sites H1, H2, H3, H4, P4, P5) from 2000 to 2009

(data compiled from BWP Consulting 2000-2009)

The total number of taxa provides a measure of the diversity of a benthic invertebrate community and is typically inversely related to impairment of water quality. Due to the variability in taxonomic identification methods employed by BWP Consulting over the period of 2000-2009, only the total number of Orders could be compiled, rather than a more detailed assessment of Families, species, or genera. This data is presented in Figure 5.9. Sites H1 and P5 have the greatest diversity, indicating good water quality. Site H3 has the lowest diversity, 
followed by $\mathrm{H} 2$ and $\mathrm{P} 4$, which suggests poor habitat quality at these sites. There is no clear pattern of change in the number of taxa at each site over time.

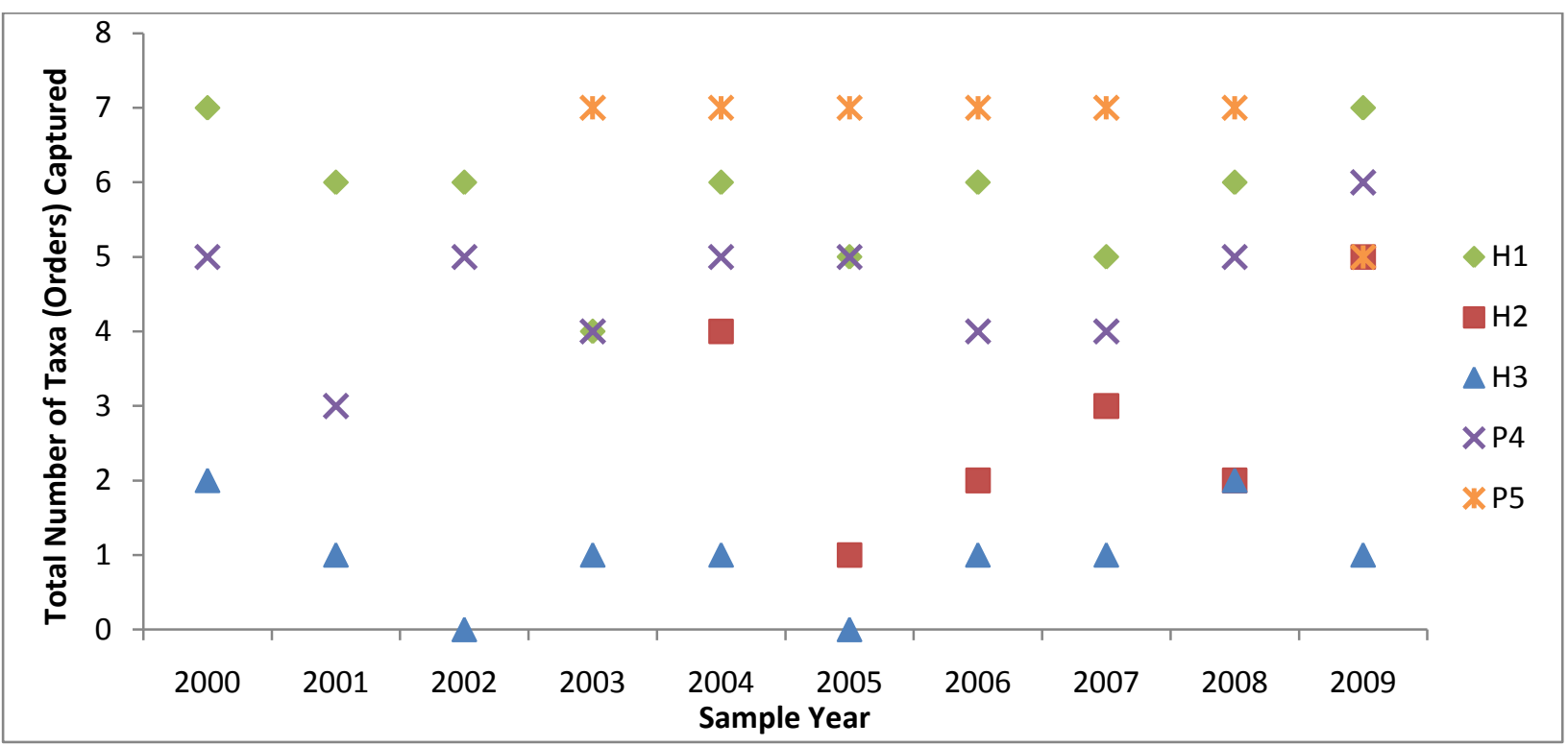

Figure 5.9: Total number of benthic macroinvertebrate taxa (orders) captured in the Pennask Creek watershed (sites H1, H2, H3, H4, P4, P5) from 2000 to 2009

(data compiled from BWP Consulting 2000-2009)

The total number of taxa in the Orders of Ephemeroptera, Plecoptera, and Trichoptera (EPT) within a benthic macroinvertebrate community is directly related to water quality, since these species are generally sensitive to poor water quality. The total number of EPT taxa was calculated for 2008 and 2009, since the organisms were identified to the genus level in these years. These data are presented in Figure 5.10. The total number of EPT taxa is highest at site P5, followed by sites P4 and H1, indicating good water quality at these sites. A complete absence of EPT taxa at site H3 in both 2008 and 2009 indicates poor water and sediment quality. Site H2 had an absence of EPT taxa in 2008, but an acceptable number (7) in 2009, indicating a possible improvement in water and sediment quality and a re-colonization of this location by these organisms. 


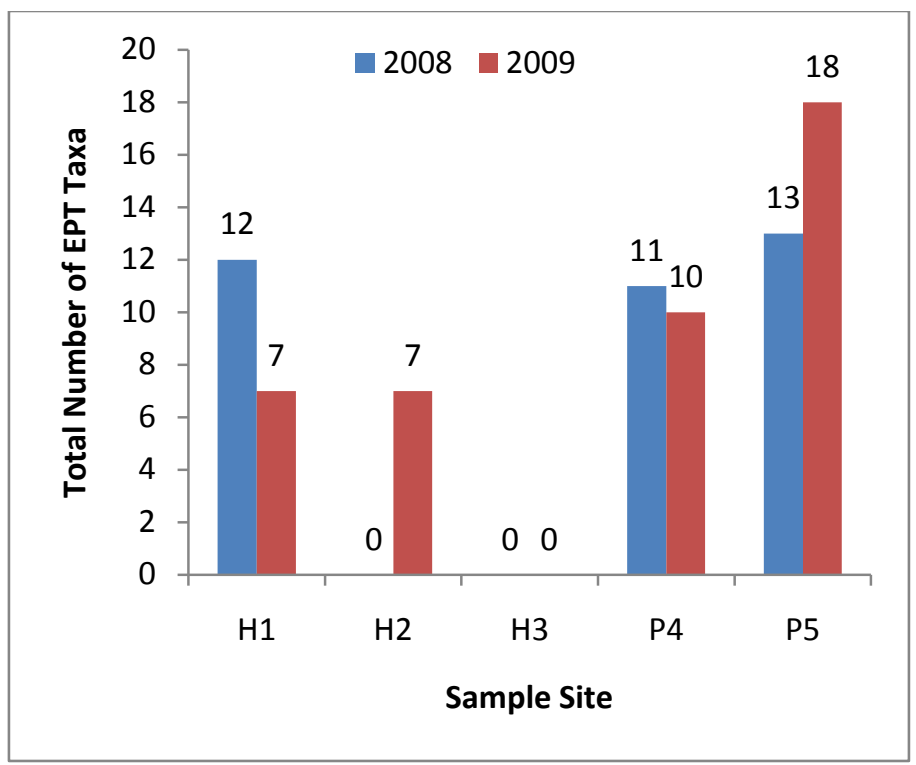

Figure 5.10: Total number of EPT taxa captured in the Pennask Creek watershed (sites H1, H2, $\mathrm{H3}, \mathrm{H4}, \mathrm{P4}, \mathrm{P5}$ ) in 2008 and 2009

(data compiled from BWP Consulting 2008, 2009)

The abundance of EPT organisms relative to the total abundance of benthic invertebrates (as a percentage) is a measure of community composition that is related to water and sediment quality. Relative, rather than absolute, abundance is used because the relative contribution of individuals to the total fauna is more informative than abundance alone (Plafkin et al. 1989). As the percentage of EPT organisms in a community increases, this can signal an improvement in water quality. However, a healthy and stable assemblage of benthic macroinvertebrates will be relatively consistent in its proportional representation, though individual abundances may vary (Plafkin et al. 1989). The relative abundance of EPT organisms for the Pennask Creek watershed is presented in Table 5.3. The percentages for site P5 are relatively consistent from year to year $($ range $=19 \%$ to $55 \%$, mean $=40 \%$, median $=44 \%$ ), indicating a healthy and stable benthic invertebrate community. Site $\mathrm{P} 4$ also exhibits consistent and high relative EPT values (range $=74 \%$ to $97 \%$ ), indicating good water and sediment quality at this site. Relative EPT abundance at site $\mathrm{H} 1$ is variable from year to year (range 35\% to 85\%), indicating an unstable benthic invertebrate community. This is likely due to perturbations of this section of Highway Creek during remediation efforts over the years. The relative EPT abundance values for sites H2 and $\mathrm{H} 3$ are difficult to interpret due the low total abundance of invertebrates at these sites each year ( $<10$ in all years for $\mathrm{H} 3$ and all years except 2009 for $\mathrm{H} 2)$. 
Table 5.3: Relative abundance of EPT organisms to total abundance of benthic macroinvertebrates in the Pennask Creek watershed (sites H1, H2, H3, H4, P4, P5) from 2000-2009

(data compiled from BWP Consulting 2000-2009)

\begin{tabular}{|c|cc|cccccccc|}
\hline \multirow{2}{*}{$\begin{array}{c}\text { Site } \\
\text { ID }\end{array}$} & \multicolumn{7}{|c|}{ Relative Abundance of EPT Organisms to the Total Abundance } \\
\cline { 2 - 12 } & 2000 & 2001 & 2002 & 2003 & 2004 & 2005 & 2006 & 2007 & 2008 & 2009 \\
\hline H1 & $35 \%$ & $51 \%$ & $54 \%$ & - & $46 \%$ & $68 \%$ & $77 \%$ & $85 \%$ & $58 \%$ & $39 \%$ \\
\hline H2 & - & - & - & - & $50 \%$ & $0 \%$ & $80 \%$ & $67 \%$ & $0 \%$ & $43 \%$ \\
\hline H3 & $0 \%$ & $100 \%$ & $0 \%$ & $0 \%$ & $0 \%$ & - & $0 \%$ & $0 \%$ & - & $0 \%$ \\
\hline P4 & $74 \%$ & $81 \%$ & $88 \%$ & $97 \%$ & $80 \%$ & $92 \%$ & $90 \%$ & $91 \%$ & $88 \%$ & $79 \%$ \\
\hline P5 & - & - & - & $45 \%$ & $32 \%$ & $44 \%$ & $55 \%$ & $19 \%$ & $35 \%$ & $49 \%$ \\
\hline
\end{tabular}

- data not available for calculation

Overall, the abundance of benthic macroinvertebrates present in Highway Creek downstream of Highway $97 \mathrm{C}$ is low, indicating poor water quality. The abundance and diversity increases in Pennask Creek with distance from the Highway Creek confluence, signifying a gradual improvement in water quality with distance from the ARD source. The benthic macroinvertebrate community at site P5 (at a great distance downstream from the confluence of Highway and Pennask Creeks) appears to be healthy and stable, providing a good food source for fish in the area.

\subsubsection{Comparison to water quality guidelines and toxicity literature}

The water quality parameters measured in this study were compared to BC and/or CCME water quality guidelines for the protection of aquatic life, when available. $\mathrm{pH}$, dissolved $\mathrm{Al}$, total $\mathrm{Cu}$ and total $\mathrm{Zn}$ concentrations all contravened water quality guidelines at one or more sample sites in the Pennask Creek watershed. Accordingly, the discussion here will focus on these parameters and the potential biological impacts posed by levels seen in the watershed.

\subsubsection{1 pH}

For $\mathrm{pH}$, a range of 6.5 to 9.0 is acceptable according to both the $\mathrm{BC}$ and CCME guidelines. Site $\mathrm{H} 2$ exhibited $\mathrm{pH}$ values below this range in both July and September (6.2 and 6.3, respectively), site $\mathrm{H} 3$ exhibited a $\mathrm{pH}$ value below this range in September (6.2), and all other sample sites had $\mathrm{pH}$ values within the acceptable range. Weiner et al. (1986) defined the critical $\mathrm{pH}$ for rainbow trout as 5.5 because below this level, reproductive success is compromised. In general, aquatic insects have a high toxicological tolerance to low $\mathrm{pH}$ values, however, they to exhibit $\mathrm{pH}$ 
avoidance behaviours that may govern their distribution (BCMOE 1991). It is therefore unlikely that the $\mathrm{pH}$ values seen in Highway Creek, alone, would be detrimental to aquatic life.

\subsubsection{Sulphate}

The $\mathrm{BC}$ water quality guideline for sulphate is $100 \mathrm{mg} / \mathrm{L}$ (measured as $\mathrm{SO}_{4}$ ), which is a maximum concentration that should not be exceeded at any time. The sulphate concentration at all sites in this study was below this guideline value. BCMOE (2006) also has an alert level for sulphate of $50 \mathrm{mg} / \mathrm{L}$ (measured as $\mathrm{SO}_{4}$ ), which site $\mathrm{H} 3$ exceeded. However, this guideline was set due to conflicting evidence regarding the sensitivity of mosses to sulphate concentrations above this level and is therefore not of major concern in this study.

\subsubsection{Aluminum}

The $\mathrm{BC}$ water quality guideline for dissolved $\mathrm{Al}$ is $0.10 \mathrm{mg} / \mathrm{L}$ when $\mathrm{pH}$ is $\geq 6.5$, and is lower at $\mathrm{pH}$ values < 6.5. For most sites in the Pennask Creek watershed, the applicable guideline is 0.10 $\mathrm{mg} / \mathrm{L}$. This value is exceeded only by sites P2 $(0.27 \mathrm{mg} / \mathrm{L})$ and P4 $(1.67 \mathrm{mg} / \mathrm{L})$ in July. It is unclear why site P2, which should be unaffected by Highway 97C ARD runoff, would be in exceedance of this value. Site P4, however, is downstream of the confluence with Highway Creek, and therefore receives ARD/ML contaminated runoff. For sites $\mathrm{H} 2$ and $\mathrm{H} 3$, the $\mathrm{pH}$ values dipped below 6.5 (to 6.2 and 6.3), so the guideline value for dissolved Al must be adjusted accordingly. At a pH of 6.2 and 6.3, the guideline values are $0.059 \mathrm{mg} / \mathrm{L}$ and 0.066 $\mathrm{mg} / \mathrm{L}$, respectively. Both sites $\mathrm{H} 2$ and $\mathrm{H} 3$ exceeded the applicable guideline values with dissolved $\mathrm{Al}$ concentrations of $0.289 \mathrm{mg} / \mathrm{L}$ and $0.243 \mathrm{mg} / \mathrm{L}$ for $\mathrm{H} 2$, and $1.628 \mathrm{mg} / \mathrm{L}$ and 0.260 $\mathrm{mg} / \mathrm{L}$ for H3, in July and September respectively. Driscoll et al. (1980) reported that surges of dissolved $\mathrm{Al}$ into streams during periods of snowmelt and heavy rainfall (when $\mathrm{pH}$ is low) are potentially lethal to fish eggs and fry. Witters et al. (1996) show that trout experience acute respiratory dysfunction and mortality (98\%) in areas where acidic waters mix with neutral waters, at a $\mathrm{pH}$ of 6.4 and $\mathrm{Al}$ concentration of $0.076 \mathrm{mg} / \mathrm{L}$, due to the rapid precipitation of $\mathrm{Al}$ hydroxides. Similar conditions to those seen in these two studies are present in Highway Creek, at sites $\mathrm{H} 2$ and $\mathrm{H} 3$, indicating a very high toxicity to fish in this area of the watershed. The visible presence of a white precipitate in sediments and on water surface in Highway Creek also provides evidence of $\mathrm{Al}$ precipitation. 


\subsubsection{Copper}

The $\mathrm{BC}$ water quality guideline for maximum total $\mathrm{Cu}$ is hardness dependent. It is calculated using the following formula:

$$
\text { maximum total Cu concentration }\left(\frac{\mu g}{L}\right)=(0.094 * \text { hardness })+2
$$

where: hardness is measured in $\mathrm{mg} / \mathrm{L}\left(\mathrm{CaCO}_{3}\right)$

For the Pennask Creek watershed, hardness values range from $17.7 \mathrm{mg} / \mathrm{L}$ to $88.3 \mathrm{mg} / \mathrm{L}$, with a mean of $37.9 \mathrm{mg} / \mathrm{L}$. Accordingly, the maximum allowable total $\mathrm{Cu}$ varies from $3.66 \mu \mathrm{g} / \mathrm{L}$ to $10.3 \mu \mathrm{g} / \mathrm{L}$, with a mean of $5.6 \mu \mathrm{g} / \mathrm{L}$. The analytical detection limit for $\mathrm{Cu}$ in this study $(0.005$ $\mathrm{mg} / \mathrm{L}$ ) is approximately equal to the mean water quality guideline value. In July, the total $\mathrm{Cu}$ concentration at all sample sites exceeded the guideline values. The same was true in September for all sites where the total $\mathrm{Cu}$ concentration was greater than the detection limit. These results indicate a high natural background level of $\mathrm{Cu}$ in the Pennask Creek watershed, likely due to the elevated $\mathrm{Cu}$ content of local rocks and soils. In this case, the acceptable increase in the total $\mathrm{Cu}$ concentration that is allowable, if any, should be based on site-specific criteria (BCMOE 2006). The $\mathrm{Cu}$ concentrations present in the watershed are at sub-lethal levels for fish and may be expected to affect swimming performance, growth rates, immunity, membrane permeability of gills (Barry et al. 2000), and olfactory response (Baldwin et al. 2003, McIntyre et al. 2008). For salmonids, olfactory cues convey important information regarding habitat quality, predators, mates and the fishes' natal stream (Baldwin et al. 2003). Therefore, impairment is likely to adversely affect survival and reproductive success. McIntyre et al. (2008) reported that a 30 minute exposure to a dissolved $\mathrm{Cu}$ concentration of $20 \mu \mathrm{g} / \mathrm{L}$ caused an $82 \%$ reduction in olfactory response of salmonids. Concentrations at sites $\mathrm{H} 2$ and $\mathrm{H} 3$ were $\geq 20 \mu \mathrm{g} / \mathrm{L}$, indicating potential sub-lethal affects to fish.

\subsubsection{Zinc}

The $\mathrm{BC}$ water quality guideline for total zinc concentration is also hardness dependent. At hardness values $\leq 90 \mathrm{mg} / \mathrm{L} \mathrm{CaCO}_{3}$ (all sites in the Pennask Creek watershed), the Zn guideline is $33 \mu \mathrm{g} / \mathrm{L}$. This guideline value is based on a $96 \mathrm{~h} \mathrm{LC50} \mathrm{of} 66 \mu \mathrm{g} / \mathrm{L}$ for rainbow trout (with a safety factor of 0.5) and should be protective of acute and lethal effects (BCMOE 1981). The analytical detection limit for $\mathrm{Zn}$ in this study was $0.01 \mathrm{mg} / \mathrm{L}$, which is less than the guideline 
value. In July, $\mathrm{Zn}$ was detected only at sites $\mathrm{H} 2$ and $\mathrm{H} 3$ at concentrations of $0.22 \mathrm{mg} / \mathrm{L}$ and 0.38 $\mathrm{mg} / \mathrm{L}$ (6.7 and 11.5 times greater than the guideline value), respectively. In September, Zn was detected only at sites $\mathrm{H} 2, \mathrm{H} 3$ and $\mathrm{P} 4$ at concentrations of $0.36 \mathrm{mg} / \mathrm{L}, 0.73 \mathrm{mg} / \mathrm{L}$ and $0.03 \mathrm{mg} / \mathrm{L}$ $(10.9,22.1$ times greater and approximately equal to the guideline value), respectively. The total $\mathrm{Zn}$ concentrations seen at sites $\mathrm{H} 2$ and $\mathrm{H} 3$ are 3 to 11 times greater than the $96 \mathrm{~h} \mathrm{LC}_{50}$ for rainbow and consequently are likely to be lethal to rainbow trout. Sublethal affects may occur downstream of the confluence of Highway and Pennask Creeks (near site P4), including avoidance behaviour at concentrations $\geq 0.0056 \mathrm{mg} / \mathrm{L}$ (Sorensen 1991).

\subsubsection{Cumulative effects of $\mathrm{Cu}$ and $\mathrm{Zn}$}

Toxicity thresholds, which are used to establish water quality criteria, are generally investigated without consideration of other contaminants present within the mixture. In reality, interactions between metal species can influence the toxicity of a chemical mixture. Mixtures of $\mathrm{Cu}$ and $\mathrm{Zn}$ were demonstrated to cause both additive and synergistic toxicities in exposure studies utilizing rainbow trout, depending on water hardness (Sorenson 1991, Todd et al. 2007). It is therefore likely that the toxicity due to metal contamination of the Pennask Creek watershed is greater than that predicted through consideration of the $\mathrm{Cu}$ and $\mathrm{Zn}$ water quality criteria individually.

\subsubsection{Comparison to sediment quality guidelines and toxicity literature}

The sediment quality parameters measured in this study were compared to BC and/or CCME sediment quality guidelines for the protection of aquatic life, where applicable. For most metals, both the BC and CCME guidelines give the same ISQG and PEL values. For Fe and Ni, BC provides guideline values but they are in the form of LELs and SELs, while CCME does not have guideline values for these two metals. Sediment $\mathrm{As}, \mathrm{Cu}, \mathrm{Fe}, \mathrm{Ni}$ and $\mathrm{Zn}$ total metal contents exceeded sediment quality guidelines at one or more sample sites in the Pennask Creek watershed. Accordingly, the discussion here will focus on these metals and the potential biological impacts posed by levels seen in the watershed. All metal content values are provided on a dry weight basis.

\subsubsection{Arsenic}

The ISQG value for As is $5.9 \mathrm{mg} / \mathrm{kg}$, while the PEL is $17 \mathrm{mg} / \mathrm{kg}$. Sites H1 (11.4 and 15.7 $\mathrm{mg} / \mathrm{kg}), \mathrm{P} 3(12.1$ and $9.5 \mathrm{mg} / \mathrm{kg})$ and P4 (21.8 and $10.1 \mathrm{mg} / \mathrm{kg})$ exceeded the ISQG in both July and September respectively, while sites H2 $(7.5 \mathrm{mg} / \mathrm{kg})$ and H3 $(7.6 \mathrm{mg} / \mathrm{kg})$ exceeded the ISQG in July only. The July value for site P4 also exceeded the PEL for As. These results indicate 
sediments enriched in As in both Highway Creek and the east branch of Pennask Creek, due to either elevated background levels or contamination from ARD/ML. Generally, As is associated with fractions of the sediments that are not considered to be biologically available. However, As can be released as a result of changes to the ambient environmental conditions, such as disturbance of the sediment, a decrease in $\mathrm{pH}$, or an increase in redox potential. Microorganisms in sediments can transform inorganic As into an organic form that can ultimately accumulate in other aquatic organisms (Bright et al. 1996). In this study, the easily extractable fraction (and thus potentially bioavailable) of As was determined for each sample, with results indicating that the As at all sample sites was approximately $20 \%$ bioavailable. Thus, it is relatively unlikely that adverse biological effects would occur in the Pennask Creek sediments due to the presence of As. Adverse biological effects from As exposure include decreased benthic invertebrate abundance, increased mortality, and behavioural changes in aquatic organisms (CCME 1999a).

\subsubsection{Copper}

The ISQG value for $\mathrm{Cu}$ is $35.7 \mathrm{mg} / \mathrm{kg}$ and the PEL is $197 \mathrm{mg} / \mathrm{kg}$. Sites H1 (40.3 and 49.3 $\mathrm{mg} / \mathrm{kg}), \mathrm{H} 2$ (210.4 and $191.4 \mathrm{mg} / \mathrm{kg}), \mathrm{H} 3$ (166.8 and $130.9 \mathrm{mg} / \mathrm{kg}$ ) and P4 (71.7 and $51.7 \mathrm{mg} / \mathrm{kg})$ exceeded the ISQG in both July and September, respectively. Site H2 also exceeded the PEL for $\mathrm{Cu}$ in July. These results indicate that the sediments are enriched in $\mathrm{Cu}$ downstream of the Highway 97C ARD/ML source, with values at $\mathrm{H} 2$ and $\mathrm{H} 3$ indicating a significant potential for causing adverse biological effects. Adverse biological effects from $\mathrm{Cu}$ exposure include decreased benthic invertebrate diversity and abundance, increased mortality and behavioural changes in aquatic organisms (CCME 1999b). Copper associated with sediment fractions that exhibit cation exchange capacity or that are easily reducible are considered to be the most readily bioavailable (Campbell and Tessier 1996). In this study it was determined that the easily extractable (and potentially most bioavailable) fraction $26 \%$ of the total $\mathrm{Cu}$ content, on average, with higher percentages (32-37\%) at sites $\mathrm{H} 2$ and $\mathrm{H} 3$. Changes in ambient environmental conditions, as mentioned for As above, can increase the bioavailability of $\mathrm{Cu}$ associated with inorganic solid phases, Fe and Mn oxides and organic matter.

\subsubsection{Iron}

BC sediment quality guidelines for Fe include a LEL of 21,200 mg/kg and a SEL of 43,766 $\mathrm{mg} / \mathrm{kg}$. Site H1 exceeded the LEL in September $(21,968 \mathrm{mg} / \mathrm{kg}), \mathrm{H} 2$ exceeded the LEL in both 
July and September $(25,881 \mathrm{mg} / \mathrm{kg}$ and 27,213 mg/kg, respectively), P2 exceeded the LEL in September $(23,914 \mathrm{mg} / \mathrm{kg})$, and P4 exceeded the LEL in July $(23,376 \mathrm{mg} / \mathrm{kg})$. None of these values approach that of the SEL. Since the sediment Fe levels are only slightly greater than the LEL, it is unlikely that any adverse biological effects would be experienced by aquatic biota due to exposure to $\mathrm{Fe}$ in the sediments. Little data regarding sediment Fe toxicity is available in the literature. Soucek et al. (2000b) found that sediment Fe content was significantly correlated $(\mathrm{r}=$ -0.95 at $\mathrm{p}<0.05$ ) with sediment test survival of Daphnia magna, however they suggest that Fe in sediments may or may not have a causal role in sediment toxicity.

\subsubsection{Nickel}

BC sediment quality guidelines for Ni include a LEL of $16 \mathrm{mg} / \mathrm{kg}$ and a SEL of $75 \mathrm{mg} / \mathrm{kg}$. Site $\mathrm{H} 1, \mathrm{H} 2, \mathrm{H} 3$ and P4 exceeded the LEL in both July and September with levels of 37.5 and 33.0 $\mathrm{mg} / \mathrm{kg}, 34.2$ and $36.8 \mathrm{mg} / \mathrm{kg}, 42.9$ and $22.9 \mathrm{mg} / \mathrm{kg}$, and 77.8 and $37.2 \mathrm{mg} / \mathrm{kg}$, respectively. Site P4 also exceeded the SEL in July. Little data regarding sediment Ni toxicity is available in the literature.

\subsubsection{Zinc}

The ISQG value for $\mathrm{Zn}$ is $123 \mathrm{mg} / \mathrm{kg}$ and the PEL is $315 \mathrm{mg} / \mathrm{kg}$. Sites H1 (395 and $452 \mathrm{mg} / \mathrm{kg}$ ), H2 (528 and $659 \mathrm{mg} / \mathrm{kg}), \mathrm{H} 3$ (515 and $389 \mathrm{mg} / \mathrm{kg})$, and P4 (743 and $540 \mathrm{mg} / \mathrm{kg}$ ) exceeded the ISQG and PEL values in both July and September. Site P3 exceeded the ISQG in July only (140 $\mathrm{mg} / \mathrm{kg}$ ). Site P5 was only sampled in September, and exceeded both the ISQG and PEL for Zn with a sediment $\mathrm{Zn}$ content of $330 \mathrm{mg} / \mathrm{kg}$. These results indicated serious contamination of the sediments in Highway Creek and Pennask Creek, downstream of the confluence with Highway Creek, even at a great distance (site P5). Since many of the sediment $\mathrm{Zn}$ contents exceed the PEL, adverse biological effects are likely to be experienced by aquatic biota in the Pennask Creek watershed. Adverse biological effects due to exposure to $\mathrm{Zn}$ in the sediments may include decreased biological diversity and abundance, increased mortality and behavioural changes (CCME 1999c). Zn has a strong affinity for Fe and Mn oxides and organic matter, resulting in its deposition in sediments associated with these materials (Campbell and Tessier 1996). As for As and $\mathrm{Cu}, \mathrm{Zn}$ associated with sediment fractions that have a high cation exchange capacity and that are easily reducible, is most bioavailable. In this study it was determined that the easily extractable (and potentially most bioavailable) fraction is $27 \%$ of the total $\mathrm{Zn}$ content, on average, with higher percentages (30-34\%) at sites downstream of the Highway 97C ARD 
source. At sites $\mathrm{H} 2, \mathrm{H} 3$ and $\mathrm{P} 4$, the extractable $\mathrm{Zn}$ content is greater than the ISQG. This indicates that there is very likely to be a sufficient level of bioavailable $\mathrm{Zn}$ for adverse biological effects to occur in organisms living in these areas.

\subsubsection{Toxic effect to luminescent bacteria}

Sample sites H1, H3, P1 and P4 were subjected to the Microtox ${ }^{\mathrm{TM}}$ SPT. Results are presented in Table 4.14. According to the interpretation guidelines outlined by Environment Canada (2002), none of these sites are considered to be toxic to the luminescent bacteria Vibrio fischeri. The $\mathrm{IC}_{50}$ values for $\mathrm{H} 1, \mathrm{H} 3, \mathrm{P} 1$ and $\mathrm{P} 4$ are 93,086 mg/L, $3842 \mathrm{mg} / \mathrm{L}, 23,967 \mathrm{mg} / \mathrm{L}$ and 70,666 mg/L, respectively. Although the Microtox ${ }^{\mathrm{TM}}$ SPT interpretation for $\mathrm{H} 3$ is 'not toxic', it is the most highly contaminated site and resulted in the lowest $\mathrm{IC}_{50}$ value. This indicates that it had the most significant inhibitory effect on Vibrio fischeri.

The Microtox ${ }^{\mathrm{TM}} \mathrm{SPT}$ response $\left(\mathrm{IC}_{50}\right)$ was very strongly positively correlated (0.999) to the benthic community structure (average number of taxa per station, as presented in Figure 5.9). Test response and the total $\mathrm{Cu}$ content of the sediment at each site were negatively correlated (0.61). The benthic community structure and total sediment $\mathrm{Cu}$ content also show a very strong negative correlation (-0.996). This demonstrates that when the total sediment $\mathrm{Cu}$ content is high, the benthic community diversity is low, and the luminescent bacteria Vibrio fischeri will show an inhibitory response. No clear relationships were apparent for the test response, benthic community structure and other total sediment metal contents. Zajdlik et al. (2000) carried out a study examining the relationships between sediment chemistry, benthic community structure and biological toxicity tests. They reported that the Microtox ${ }^{\mathrm{TM}} \mathrm{SPT} \mathrm{IC}_{50}$ was negatively correlated with sediment contamination and positively correlated with benthic community structure. This result supports the relationship seen between the $\mathrm{IC}_{50}$, total sediment $\mathrm{Cu}$ content and benthic community structure in the Pennask Creek watershed.

\subsection{Impact of Local Geology}

Results of qualitative XRD carried out in this study show that the rock samples collected from the Pennask Creek watershed contain mainly quartz $\left(\mathrm{SiO}_{2}\right)$ and plagioclase $\left(\mathrm{NaAlSi}_{3} \mathrm{O}_{8}-\right.$ $\left.\mathrm{CaAl}_{2} \mathrm{Si}_{2} \mathrm{O}_{8}\right)$. Only one rock sample from this study contained pyrite $\left(\mathrm{FeS}_{2}\right)$, in a very small amount. Due the lack of sulphide minerals, it is unlikely that the rocks along the streambed and banks of Pennask and Highway Creek are acid-generating. 
Evidence that rocks in other areas of the Pennask Creek watershed are acid-generating has been reported by several sources. According to the MINFILE reports discussed in section 2.3.1, mineral showings around Pennask Mountain, in the upper southern portion of the Pennask Creek watershed contain elevated levels of $\mathrm{Au}, \mathrm{Ag}, \mathrm{Cu}, \mathrm{Pb}$ and $\mathrm{Zn}$, along with sulphide minerals (MEMPR 2007). Therefore, the headwaters of the watershed contain minerals that can generate acidity, lower the $\mathrm{pH}$ of surface runoff and/or groundwater and cause the release of metals (such as $\mathrm{Cu}, \mathrm{Pb}$, and $\mathrm{Zn}$ ) from these rocks and others in the area (Morin and Hutt 2003). Grunenberg and Tomlinson (2001) studied the rock cuts along Highway 97C, to the east of Highway Creek. They reported that the rock cuts were made up mainly of silica and aluminosilicate minerals, which supports the findings of the geological analyses carried out in this study. However, Grunenberg and Tomlinson (2001) also found pyrite to be common in the sedimentary rocks of the rock cuts, occurring as microbedding, very fine-grained disseminations and secondary fracture fillings. Rock samples were subjected to acid-base accounting and were found to contain sulphide levels great enough (up to approximately $4 \%$ by weight) to generate acidity. The neutralization potential of these samples were relatively low (average of $3.5 \mathrm{~kg}$ $\mathrm{CaCO}_{3} /$ tonne), resulting in all samples being net acid-generating. The authors also found that metals (such as $\mathrm{Cu}$ ) were not associated with the sulphide minerals but with other minerals and therefore leaching of these metals would occur due to the acidic drainage rather than the oxidation of pyrite itself.

As the acid drainage produced by the rocks in the headwaters and the rock cuts along the highway travels towards and through the Pennask Creek watershed, it has the potential to leach metals from the surrounding rocks, soils, and sediments. Results from XRF chemical analysis of the rocks sampled in this study provide a glimpse of the availability of such metals for leaching. Si was the most plentiful element ( $29.6 \%$ by weight), corresponding to the high levels of quartz and plagioclase in the samples, as seen in the XRD results. Al and Fe were present at approximately $8 \%(\mathrm{wt})$, while $\mathrm{Mg}$ was present at slightly greater than $2 \%(\mathrm{wt})$. Trace elements, including $\mathrm{Cu}, \mathrm{Mn}, \mathrm{Ni}$ and $\mathrm{Zn}$ were also present in several rock samples in significant concentrations. $\mathrm{Cu}$ was found at $>100 \mathrm{ppm}$ in both rock samples from site P3, as well as samples from $\mathrm{H} 2$ and $\mathrm{H} 3$, with a mean value of $59 \mathrm{ppm}$ for all rock samples. This high $\mathrm{Cu}$ content might explain the elevated $\mathrm{Cu}$ found in the water and sediment samples throughout the Pennask Creek watershed. The Mn content of rock samples was greatest at site P4 (> 2000 ppm for one sample), with sites H2, H3, P1 and P3 all containing > $1000 \mathrm{ppm} \mathrm{Mn}$. Ni was found at 
levels > 100 ppm at sites H2, P2 and P4. Zn was highest at sites P4 and H1 (> 200 ppm) and at levels > $100 \mathrm{ppm}$ at sites H2, H3, P1 and P3. These results indicate considerable levels of the metals found at elevated levels in the water and sediments of the Pennask Creek watershed, suggesting the potential for metal leaching to occur as a result of acid-generation from the highway rock cuts for many years to come.

\subsection{Estimation of Risk Posed to Rainbow Trout}

\subsubsection{Problem formulation and exposure assessment}

The key receptor of concern in the Pennask Creek watershed is the rainbow trout (Oncorhynchus mykiss). The contaminants of potential concern are $\mathrm{Al}, \mathrm{Cu}$, and $\mathrm{Zn}$. These metals originate from the ARD/ML generation along Highway 97C and enter Highway Creek, which flows into Pennask Creek. Once these metals are in the water column of the creeks, fish are exposed through direct ingestion, ventilation, and direct skin contact. These metals might also partition into the stream sediments, where they may be remobilized into the water column, or taken up by benthic macroinvertebrates. Fish ingest these contaminated invertebrates as a food source and may also be exposed to the metals through this pathway. A conceptual site model is presented in Figure 5.11 to illustrate how the contaminants of concern $(\mathrm{Al}, \mathrm{Cu}$, and $\mathrm{Zn}$ ) could potentially move through the environment to the receptor of concern (rainbow trout).

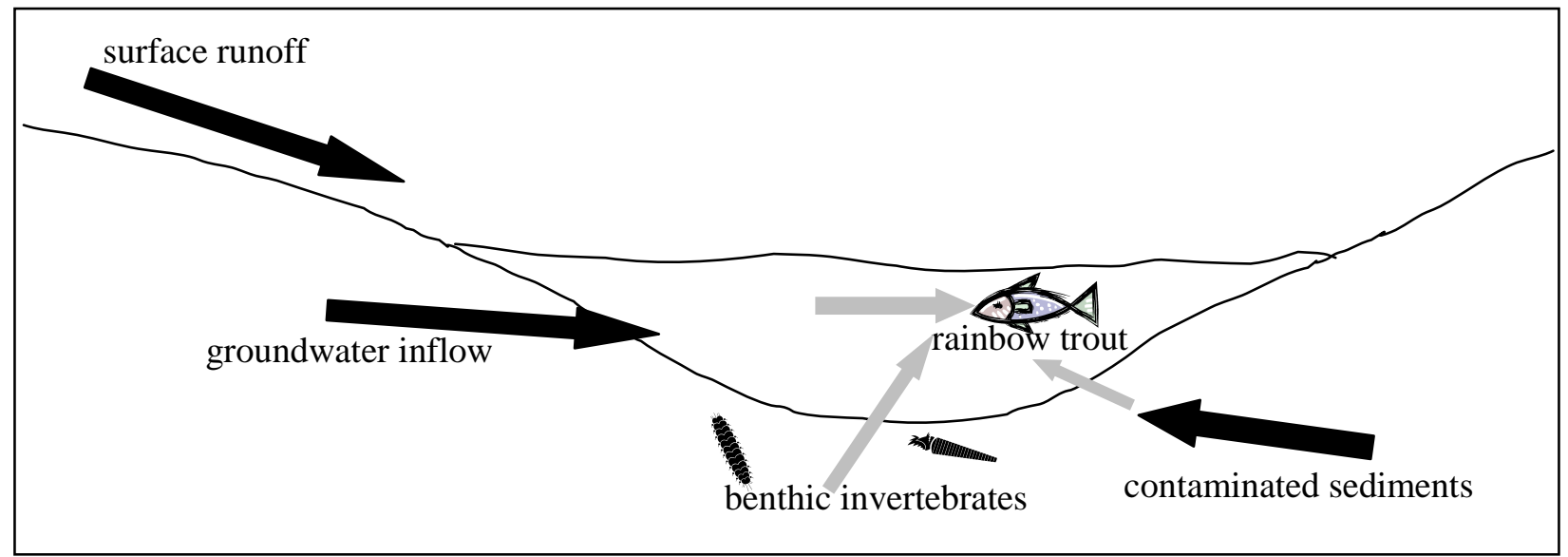

Figure 5.11 Conceptual site model for the Pennask Creek watershed (black arrows $=$ contaminant source, grey arrows $=$ potential exposure pathway) 


\subsubsection{Risk calculation and characterization}

To assess the theoretical relative risk posed by an environmental contaminant to an aquatic organism, calculation of risk quotients (RQ) is commonly applied (CCME 1996, BCMELP 1998, Todd et al. 2007, Mortula et al. 2009). This calculation is defined by the following formula:

$$
R Q=\frac{E E C}{T R V}
$$

Where: $R Q=$ risk quotient, $E E C=$ environmental concentration of contaminant, $T R V=$ toxicity reference value

A RQ value $>1$ indicates potential risk to the organism, while a RQ of $<1$ indicates minimal risk to the organism from that contaminant. For this study, two sets of TRVs were utilized. RQ values were calculated using TRVs equivalent to the $\mathrm{BC}$ water quality guidelines for the protection of aquatic life, which should be protective of all sensitive aquatic species present in the Pennask Creek watershed. Secondly, TRVs established from the literature that are specific to the main receptor of concern, rainbow trout, were also used to calculate RQs specific to this species. Risk quotients were calculated for each sample site in the Pennask Creek watershed based on the mean metal concentrations present in water samples (Table 5.4). 
Table 5.4: Risk quotients calculated for $\mathrm{Al}, \mathrm{Cu}$, and $\mathrm{Zn}$ in the water column of the Pennask Creek watershed

\begin{tabular}{|c|c|c|c|c|c|c|}
\hline $\begin{array}{l}\text { Sample } \\
\text { Site }\end{array}$ & Metal & $\begin{array}{l}\text { Mean Metal } \\
\text { Concentration } \\
\quad(\mathrm{mg} / \mathrm{L})\end{array}$ & $\begin{array}{l}\text { BC Water } \\
\text { Quality } \\
\text { Guideline } \\
(\mathrm{mg} / \mathrm{L})^{\mathrm{b}}\end{array}$ & $\begin{array}{l}\text { Rainbow } \\
\text { Trout } \\
\text { Specific } \\
(\mathbf{m g} / \mathbf{L})^{c}\end{array}$ & $\begin{array}{c}\text { Calculated } \\
\text { RQ (BC } \\
\text { Water } \\
\text { Quality } \\
\text { Guideline) }\end{array}$ & $\begin{array}{c}\text { Calculated } \\
\text { RQ } \\
\text { (Rainbow } \\
\text { Trout } \\
\text { Specific) }\end{array}$ \\
\hline \multirow{3}{*}{ H1 } & $\mathrm{Al}^{\mathrm{a}}$ & 0.044 & 0.1 & 0.75 & 0.4 & 0.1 \\
\hline & $\mathrm{Cu}$ & 0.020 & 0.0046 & 0.054 & 4.2 & 0.4 \\
\hline & $\mathrm{Zn}$ & 0.005 & 0.033 & 0.321 & 0.2 & 0.0 \\
\hline \multirow{3}{*}{ H2 } & $\mathrm{Al}^{\mathrm{a}}$ & 0.266 & 0.066 & 0.75 & 4.0 & 0.4 \\
\hline & $\mathrm{Cu}$ & 0.031 & 0.0062 & 0.054 & 5.0 & 0.6 \\
\hline & $\mathrm{Zn}$ & 0.290 & 0.033 & 0.321 & 8.8 & 0.9 \\
\hline \multirow{3}{*}{ H3 } & $\mathrm{Al}^{\mathrm{a}}$ & 0.944 & 0.074 & 0.75 & 12.8 & 1.3 \\
\hline & $\mathrm{Cu}$ & 0.036 & 0.0091 & 0.054 & 3.9 & 0.7 \\
\hline & $\mathrm{Zn}$ & 0.557 & 0.033 & 0.321 & 16.9 & 1.7 \\
\hline \multirow{3}{*}{$\mathbf{P 1}$} & $\mathrm{Al}^{\mathrm{a}}$ & 0.042 & 0.1 & 0.75 & 0.4 & 0.1 \\
\hline & $\mathrm{Cu}$ & 0.018 & 0.0038 & 0.054 & 4.7 & 0.3 \\
\hline & $\mathrm{Zn}$ & 0.005 & 0.033 & 0.321 & 0.2 & 0.0 \\
\hline \multirow{3}{*}{$\mathbf{P 2}$} & $\mathrm{Al}^{\mathrm{a}}$ & 0.148 & 0.1 & 0.75 & 1.5 & 0.2 \\
\hline & $\mathrm{Cu}$ & 0.010 & 0.0054 & 0.054 & 1.8 & 0.2 \\
\hline & $\mathrm{Zn}$ & 0.005 & 0.033 & 0.321 & 0.2 & 0.0 \\
\hline \multirow{3}{*}{ P3 } & $\mathrm{Al}^{\mathrm{a}}$ & 0.023 & 0.1 & 0.75 & 0.2 & 0.0 \\
\hline & $\mathrm{Cu}$ & 0.015 & 0.0047 & 0.054 & 3.2 & 0.3 \\
\hline & $\mathrm{Zn}$ & 0.005 & 0.033 & 0.321 & 0.2 & 0.0 \\
\hline \multirow{3}{*}{ P4 } & $\mathrm{Al}^{\mathrm{a}}$ & 0.848 & 0.1 & 0.75 & 8.5 & 1.1 \\
\hline & $\mathrm{Cu}$ & 0.049 & 0.0059 & 0.054 & 8.2 & 0.9 \\
\hline & $\mathrm{Zn}$ & 0.016 & 0.033 & 0.321 & 0.5 & 0.0 \\
\hline \multirow{3}{*}{ P5 } & $\mathrm{Al}^{\mathrm{a}}$ & 0.010 & 0.1 & 0.75 & 0.1 & 0.0 \\
\hline & $\mathrm{Cu}$ & 0.006 & 0.0061 & 0.054 & 1.0 & 0.1 \\
\hline & $\mathrm{Zn}$ & 0.005 & 0.033 & 0.321 & 0.2 & 0.0 \\
\hline
\end{tabular}

All mean metal concentrations are total concentrations unless otherwise specified.

If metal concentration values were below detection limit, value used $=0.5 *$ detection limit.

a dissolved $\mathrm{Al}$ concentration

b calculated from BCMOE (2006) using the mean hardness value at each sample site

c Data compiled from Todd et al. (2007)

The RQ values calculated using the conservative $\mathrm{BC}$ water quality guidelines suggest that $\mathrm{Cu}$ poses a potential risk to aquatic organisms at all sites in the Pennask Creek watershed, Al poses a potential risk at sites downstream of the ARD source, and $\mathrm{Zn}$ poses a potential risk at sites in Highway Creek downstream of the ARD source. Caution must be exercised when interpreting the RQ values for $\mathrm{Cu}$ because there is a high background level of this metal in the watershed. 
Site P4 is the only site where the RQ for $\mathrm{Cu}$ is considerably greater than that at the background sites (H1, P1, P2, and P3). The RQ values calculated using the BC water quality guidelines may overestimate the risk posed to aquatic life in Pennask Creek because the TRVs utilized are designed to be protective of the most sensitive species, which may or may not be present in the watershed. However, there is also the potential for an underestimation of risk due to exposure to a mixture of contaminants, when the RQ values only represent individual contaminant exposures.

When the results of the RQ calculations using BC water quality guidelines are interpreted alongside the compiled benthic invertebrate data (BWP 2000-2009), clear patterns can be seen. Benthic invertebrate abundance (Figure 5.8) and diversity (Figure 5.9) were low for sites H2, H3 and P4 (downstream of the ARD source), corresponding to RQ values considerably > 1 for Al and $\mathrm{Cu}$ at all three sites, and $\mathrm{Zn}$ at sites $\mathrm{H} 2$ and $\mathrm{H} 3$. Also, there was a complete absence of Ephemeroptera, Plecoptera and Trichoptera (EPT) organisms at sites H2 and H3 in 2008, and site H3 in 2009 (Figure 5.10). Since EPT organisms are considered to be very sensitive to poor water quality, these findings support the high risk quotient values for these two sites.

The RQ values calculated using the rainbow trout specific TRVs suggest that $\mathrm{Al}$ and $\mathrm{Zn}$ pose a potential risk to this species at sites downstream of the ARD source, while the RQ for $\mathrm{Cu}$ at site P4 is close to 1 , indicating an uncertain risk estimate and a need for further information. These species-specific RQs are likely to be more accurate predictors of the risk posed to rainbow trout by metals in the Pennask Creek watershed. However, it is also important to note that RQ calculations identify the relative risks from isolated metal exposures, while the organisms in the Pennask Creek watershed are exposed to a mixture of metals and thus a risk that may be cumulative. As such, the actual risk to rainbow trout due to ARD/ML contamination may be underestimated by this simplified assessment.

As in any scientific study, uncertainty exists in this estimation. These uncertainties arise from natural variability in environmental processes, sampling methods, analytical techniques, assumptions regarding TRVs, as well as uncertainty associated with the use of the risk quotient method. Overall, aquatic organisms are likely to experience a moderate level of risk at sites $\mathrm{H} 2$ and $\mathrm{H} 3$ due to $\mathrm{Al}$ and $\mathrm{Zn}$ contamination, and at site $\mathrm{P} 4$ due to $\mathrm{Al}$ and $\mathrm{Cu}$ contamination.

Rainbow trout are likely to experience a moderate level of risk due to $\mathrm{Al}$ and $\mathrm{Zn}$ contamination in the Pennask Creek watershed. 


\section{CHAPTER 6: CONCLUSIONS AND RECOMMENDATIONS}

\subsection{Conclusions}

\subsubsection{Extent of trace metal contamination in water and sediments}

Metal concentrations in the water and sediments of Highway Creek (particularly downstream of Highway 97C) are higher than those in Pennask Creek. Concentrations of $\mathrm{Al}, \mathrm{Cu}, \mathrm{Fe}, \mathrm{Mg}, \mathrm{Mn}$, $\mathrm{Ni}$ and $\mathrm{Zn}$ in water samples are elevated above background levels in Highway Creek downstream of the highway, but generally decrease downstream of the confluence with Pennask Creek and return to background levels before Pennask Creek flows into Pennask Lake. The concentrations of these metals have also decreased markedly since 2004, due to remediation efforts by TRANS. The Al, As, $\mathrm{Cu}$, and $\mathrm{Ni}$ contents of sediment samples show a similar spatial trend to that of the water samples, with elevated levels in Highway Creek decreasing downstream. The sediment $\mathrm{Zn}$ content, however, remains elevated near the outflow of Pennask Creek into Pennask Lake. Results of water and sediment analyses indicate that $\mathrm{Al}, \mathrm{Cu}$ and $\mathrm{Zn}$ are the main metals of concern in the Pennask Creek watershed.

\subsubsection{Biological impacts of trace metal contamination}

The abundance and diversity of benthic macroinvertebrates present in Highway Creek downstream of Highway 97C are low, indicating poor habitat quality. The abundance and diversity increases in Pennask Creek with distance from the Highway Creek confluence, signifying a gradual improvement in water quality with distance from the ARD source. The benthic macroinvertebrate community near the outflow of Pennask Creek into Pennask Lake appears to be healthy and stable, providing a good food source for fish in the area.

$\mathrm{Al}, \mathrm{Cu}$ and $\mathrm{Zn}$ concentrations in the water column at sites in Highway Creek, downstream of Highway 97C are of concern in terms of potential adverse biological impacts. At the concentrations seen in this study, it is possible that Al contamination could impact survival and reproduction of rainbow trout, while $\mathrm{Cu}$ and $\mathrm{Zn}$ contamination could cause sublethal effects on this species. Sediment $\mathrm{Cu}$ and $\mathrm{Zn}$ contents at sites in Highway Creek and Pennask Creek, downstream of Highway 97C indicate a likelihood of adverse biological effects including decreased benthic invertebrate abundance and diversity, increased mortality and behavioural changes in aquatic biota. The sediment $\mathrm{Zn}$ contents seen in this study are alarming since the 
easily extractable and bioavailable portion of the total $\mathrm{Zn}$ content exceeds the PEL at all sites in Highway Creek and in Pennask Creek as far downstream as the outflow. This indicates a high likelihood of adverse biological effects due to $\mathrm{Zn}$ contamination in the sediments.

\subsubsection{Impact of Highway 97C construction and local geology}

Rock samples collected from the stream beds and banks of Highway Creek and Pennask Creek were not found to contain minerals that indicate acid-generating potential through XRD analysis. These rock samples contained significant levels of $\mathrm{Al}, \mathrm{Cu}, \mathrm{Fe}, \mathrm{Mn}, \mathrm{Ni}$, and $\mathrm{Zn}$ and therefore may provide a source of metals that could continue to be leached into the watershed under acidic conditions for many years to come.

\subsubsection{Estimation of risk to aquatic organisms}

To estimate the ecological risk posed by metal contamination in the Pennask Creek watershed, several lines of evidence were considered. $\mathrm{Al}, \mathrm{Cu}$, and $\mathrm{Zn}$ levels in the water and sediments consistently exceeded BC and CCME guideline values for the protection of aquatic life. Toxicology literature indicates that adverse biological effects are likely at sites downstream of the ARD/ML source due to metal contamination. Benthic invertebrate monitoring over a ten year period demonstrates low abundance and diversity, as well as the complete absence of sensitive taxa at sites downstream of the Highway 97C ARD/ML source. Calculated risk quotients also indicate a likelihood of risk to aquatic organisms and specifically rainbow trout due to $\mathrm{Al}$ and $\mathrm{Zn}$ contamination of the water column in Highway Creek downstream of the ARD/ML source. Overall, the risk estimate for aquatic organisms (including rainbow trout) in the Pennask Creek watershed due to metal contamination is moderate.

\subsection{Recommendations}

Although remediation efforts have focused on collecting all contaminated drainage from the Highway 97C rock cuts, it is apparent that some ARD/ML discharge continues to enter Highway Creek, downstream of the current remediation site. It is therefore recommended that groundwater and surface water flows in this area be investigated to determine the source and location of any contaminated seep(s) into Highway Creek.

To further ascertain the ecological risk posed by metal contamination in the Pennask Creek watershed, several biological studies are recommended. To assess the bioavailability of these 
metals, aquatic organisms from several different trophic levels should be collected and subjected to analysis of tissue metal concentrations. Bioassays using benthic invertebrates and rainbow trout should also be carried out to assess the site-specific toxicity of Highway Creek and Pennask Creek water and sediments. 


\section{REFERENCES}

American Public Health Association (APHA), American Water Works Association (AWWA), and Water Environment Federation (WEF). 2005. Standard Methods for the Examination of Water and Wastewater. APHA, Washington, DC.

Arnesen, R.T. and Iversen, E.R. 1997. The Lokken project - flooding a sulphide ore mine. Proceedings: Fourth International Conference on Acid Rock Drainage. Vancouver, BC. Volume III, pp. 1093-1107.

Baldwin, D.H., Sandahl, J.F., Labenia, J.S. and Scholz, N.L. 2003. Sublethal effects of copper on coho salmon: Impacts on non-overlapping receptor pathways in the peripheral olfactory nervous system. Environmental Toxicology and Chemistry, 22(10): 2266-2274.

Barry, K.L., Grout, J.A., Levings, C.D., Nidle, B.H. and Piercey, G.E. 2000. Impacts of acid mine drainage on juvenile salmonids in an estuary near Britannia Beach in Howe Sound, British Columbia. Canadian Journal of Fisheries and Aquatic Sciences, 57: 2032-2043.

BC Ministry of Energy, Mines and Petroleum Resources (MEMPR). 2007. MINFILE Mineral Inventory. Available from: http://www.empr.gov.bc.ca/MINING/GEOSCIENCE/MINFILE/Pages/default.aspx. [Accessed 21 June 2010].

BC Ministry of Environment (BCMOE). 1981. Ambient Water Quality Guidelines for Zinc: Overview Report. Available from: http://www.env.gov.bc.ca/wat/wq/BCguidelines/zinc/zinc.html. [Accessed 26 June 2010].

BC Ministry of Environment (BCMOE). 1991. Ambient Water Quality Criteria for $p H$ : Technical Appendix. Available from: http://www.env.gov.bc.ca/wat/wq/BCguidelines/phthech.pdf. [Accessed 25 June 2010].

BC Ministry of Environment (BCMOE). 2006. Water Quality Guidelines (Criteria) Reports. Available from: http://www.env.gov.bc.ca/wat/wq/wq_guidelines.html. [Accessed 11 January 2010].

BC Ministry of Environment, Lands and Parks (BCMELP). 1998. Recommended Guidance and Checklist for Tier 1 Ecological Risk Assessment of Contaminated Sites in British Columbia. Available from: http://www.env.gov.bc.ca/epd/remediation/policy_procedure_protocol/protocols/tier1/. [Accessed 27 June 2010].

BC Ministry of Water, Land and Air Protection (BCMWLAP). 2002. Mitigation of metal leaching and acid rock drainage at mine sites. In: Environmental Trends in British Columbia 2002. Available from: http://www.elp.gov.bc.ca/soe/et02/10_mitigation/minesites.html\#. [Accessed 8 March 2010].

BC Ministry of Water, Land and Air Protection (BCMWLAP). 2003. Management Direction Statement for Pennask Creek Protected Area. Environmental Stewardship Division, Okanagan Region. March 2003. 
Bektas, S., Hisar, O., Hisar, S.A. and Yanik, T. 2008. Inhibition of cadmium on carbonic anhydrase in rainbow trout (Oncorhynchus mykiss). Fresenius Environmental Bulletin, 17(7a): 793-796.

Boult, S., Collins, D.N., White, K.N. and Curtis, C.D. 1994. Metal transport in a stream polluted by acid mine drainage - the Afon Goch, Anglesey, UK. Environmental Pollution, 84: 279284.

Brake, S.S., Connors, K.A. and Romberger, S.B. 2001. A river runs through it: Impact of acid mine drainage on the geochemistry of West Little Sugar Creek pre- and post-reclamation at the Green Valley coal mine, Indiana, USA. Environmental Geology, 40: 1471-1481.

Bright, D.A., Dodd, M. and Reimer, K.J. 1996. Arsenic in subarctic lakes influenced by gold mine effluents: The occurrence of organoarsenicals and hidden arsenic. Science of the Total Environment, 180(2): 65-182.

Broughton, L.M. and Robertson, A.M. 1992. Acid rock drainage from mines - Where we are now. IMM Minerals, Metals and Environment Conference. February 4-6, Manchester, UK. Available from: http://www.robertsongeoconsultants.com/publications/ard_mines.pdf. [Accessed 27 April 2010].

BWP Consulting. 1999. Summary of invertebrate sampling conducted in Pennask Creek and an unnamed tributary on November 25, 1999. Report to BC Ministry of Transportation and Highways.

BWP Consulting. 2000. Summary of invertebrate sampling and water quality analysis conducted on Pennask Creek and Highway Creek on October $9^{\text {th }}$ and $10^{\text {th }}$, 2000. Report to Ministry of Transportation and Highways.

BWP Consulting. 2001. Summary of water quality and invertebrate sampling conducted on Pennask Creek and Highway Creek: June 14-December 6, 2001. Report to Ministry of Transportation and Highways.

BWP Consulting. 2002. Summary of water quality and invertebrate sampling conducted on Pennask Creek and Highway Creek: June 11-November 18, 2001. Report to Ministry of Transportation.

BWP Consulting. 2003. Summary of water quality and invertebrate sampling conducted on Pennask Creek and Highway Creek: June 4-November 11, 2003. Report to Ministry of Transportation.

BWP Consulting. 2004. Summary of water quality and invertebrate sampling conducted on Pennask Creek and Highway Creek: August 30-November 14, 2004. Report to Ministry of Transportation.

BWP Consulting. 2005. Summary of water quality and invertebrate sampling conducted on Pennask Creek and Highway Creek: July 28-October, 2005. Report to Ministry of Transportation. 
BWP Consulting. 2006. Summary of water quality and invertebrate sampling conducted on Pennask Creek and Highway Creek: May 25-October 16, 2006. Report to Ministry of Transportation.

BWP Consulting. 2007. Summary of water quality and invertebrate sampling conducted on Pennask Creek and Highway Creek: May 16-October 17, 2007. Report to Ministry of Transportation.

BWP Consulting. 2008. Summary of water quality and invertebrate sampling conducted on Pennask Creek and Highway Creek: May 29-October 30, 2008. Report to Ministry of Transportation and Infrastructure.

BWP Consulting. 2009. Summary of water quality and invertebrate sampling conducted on Pennask Creek and Highway Creek: May 29-October 18, 2009. Report to Ministry of Transportation and Infrastructure.

Butler, B.A. 2009. Effect of $\mathrm{pH}$, ionic strength, dissolved organic carbon, time, and particle size on metals release from mine drainage impacted streambed sediments. Water Research, 43: 1392-1402.

Calvert, S.E., Cousens, B.L. and Soon, M.Y.S. 1985. An X-ray fluorescence spectrometric method for the determination of major and minor elements in ferromanganese nodules. Chemical Geology, 51: 9-18.

Campbell, P.G.C. and Stokes, P.M. 1985. Acidification and toxicity of metals to aquatic biota. Canadian Journal of Fisheries and Aquatic Sciences, 42(12): 2034-2049.

Campbell, P.G.C. and Tessier, A. 1996. Ecotoxicology of metals in aquatic environments: Geochemical aspects. In: Ecotoxicology: A hierarchical treatment. Newmann, M.C. and Jagoe, C.H, eds. Lewis Publishers: Boca Raton, FL.

Canadian Council of Ministers of the Environment (CCME). 1996. A framework for ecological risk assessment: General guidance. The National Contaminated Sites Remediation Program: Winnipeg, MB.

Canadian Council of Ministers of the Environment (CCME). 1999a. Canadian sediment quality guidelines for the protection of aquatic life: Arsenic. In: Canadian environmental quality guidelines, 1999, CCME: Winnipeg. Available from: http://ceqg-rcqe.ccme.ca/. [Accessed 26 June 2010].

Canadian Council of Ministers of the Environment (CCME). 1999b. Canadian sediment quality guidelines for the protection of aquatic life: Copper. In: Canadian environmental quality guidelines, 1999, CCME: Winnipeg. Available from: http://ceqg-rcqe.ccme.ca/. [Accessed 26 June 2010].

Canadian Council of Ministers of the Environment (CCME). 1999c. Canadian sediment quality guidelines for the protection of aquatic life: Zinc. In: Canadian environmental quality guidelines, 1999, CCME: Winnipeg. Available from: http://ceqg-rcqe.ccme.ca/. [Accessed 26 June 2010]. 
Canadian Council of Ministers of the Environment (CCME). 2002. Canadian sediment quality guidelines for the protection of aquatic life: Summary tables. Updated 2002. In: Canadian environmental quality guidelines, 1999, CCME: Winnipeg. Available from: http://ceqgrcqe.ccme.ca/. [Accessed 17 May 2010].

Canadian Council of Ministers of the Environment (CCME). 2007. Canadian water quality guidelines for the protection of aquatic life: Summary table. Updated December, 2007. In: Canadian environmental quality guidelines, 1999, CCME: Winnipeg. Available from: http://ceqg-rcqe.ccme.ca/. [Accessed 17 May 2010].

Caruso, B.S. and Dawson, H.E. 2009. Impacts of groundwater metal loads from bedrock fractures on water quality of a mountain stream. Environmental Monitoring and Assessment, 153: 405-425.

Dawson, G.L., Ray, G.E., Maclean, M.E. and Webster, I. 1988. Geology of the Pennask Mountain Area - 92H/16. Open File Map 1988-7: British Columbia Ministry of Energy, Mines and Petroleum Resources.

DeNicola, D.M. and Stapleton, M.G. 2002. Impact of acid mine drainage on benthic communities in streams: the relative roles of substratum vs. aqueous effects. Environmental Pollution, 119: 303-315.

Dills, G. and Rogers Jr., D.T. 1974. Macroinvertebrate community structure as an indicator of acid mine pollution. Environmental Pollution, 6: 239-262.

Driscoll, C.T. Jr., Baker, J.P., Bisogni, F.F. Jr. and Schofield, C.L. 1980. Effect of aluminum speciation on fish in dilute acidified waters. Nature, 284: 161-164.

Dubé, M.G., MacLatchy, D.L., Kieffer, J.D., Glozier, N.E., Culp, J.M. and Cash, K.J. 2005. Effects of metal mining effluent on Atlantic salmon (Salmo salar) and slimy sculpin (Cottus cognatus): Using artificial streams to assess existing effects and predict future consequences. Science of the Total Environment, 343: 135-154.

Egiebor, N.O. and Oni, B. 2007. Acid rock drainage formation and treatment: A review. AsiaPacific Journal of Chemical Engineering, 2: 47-62.

Environment Canada. 2002. Biological Test Method: Reference Method for Determining the Toxicity of Sediment Using Luminescent Bacteria in a Solid-Phase Test. Report EPS $1 / \mathrm{RM} / 42$.

Environment Canada. 2005. Guilty Plea in Pennask Creek Pollution Offenses - BC Ministry of Transportation Ordered to Pay More than \$46,000. The Green Lane: [News Release] September 27, 2005: Kelowna, BC. Available from: http://www.ec.gc.ca/media_archive/press/2005/050927_n_e.htm. [Accessed 29 April 2010].

Environment Canada. 2006. Archived Hydrometric Data: Pennask Creek Near Quilchena (08LG016). Water Survey of Canada. Available from: http://www.wsc.ec.gc.ca/hydat/H2O/index_e.cfm?cname=graph.cfm\#note. [Accessed 15 June 2010]. 
Farag, A.M., Woodward, D.F., Goldstein, J.N., Brumbaugh, W. and Meyer, J.S. 1998. Concentrations of metals associated with mining waste in sediments, biofilm, benthic macroinvertebrates, and fish from the Coeur d'Alene River Basin, Idaho. Archives of Environmental Contamination and Toxicology, 34: 119-127.

Farag, A.M., Nimick, D.A., Kimball, B.A., Church, S.E., Harper, D.D. and Brumbaugh, W.G. 2007. Concentrations of metals in water, sediment, biofilm, benthic macroinvertebrates, and fish in the Boulder River watershed, Montana, and the role of colloids in metal uptake. Archives of Environmental Contamination and Toxicology, 52: 397-409.

Feasby, G. and Jones, R.K. 1994. Report of Results of a Workshop on Mine Reclamation, Toronto, Ontario March 10-11, 1994. Workshop hosted by the IGWG-Industry Task Force on Mine Reclamation.

Feasby, G. and Tremblay, G. 1995. New technologies to reduce environmental liability from acid generating mine wastes. Proceedings of Sudbury '95 Mining and the Environment, 2: 643-647.

Feasby, D.G., Tremblay, G.A. and Weatherall, C.J. 1997. A decade of technology improvement to the challenge of acid drainage - a Canadian perspective. Fourth International Conference on Acid Rock Drainage: Vancouver, Canada, 3: i-ix.

Flemming, C.A. and Trevors, J.T. 1989. Copper toxicity and chemistry in the environment: A review. Water, Air, and Soil Pollution, 44: 143-158.

Fox, D., Robinson, C. and Zentilli, M. 1997. Pyrrhotite and associated sulphides and their relationship to acid rock drainage in the Halifax Formation, Meguma Group, Nova Scotia. Atlantic Geology, 33: 87-103.

Galán, E., Gómez-Ariza, J.L., González, I., Fernández-Caliani, J.C., Morales, E. and Giráldez, I. 2003. Heavy metal partitioning in river sediments severely polluted by acid mine drainage in the Iberian Pyrite Belt. Applied Geochemistry, 18: 409-421.

Gerhardt, A. 1993. Review of impact of heavy metals on stream invertebrates with special emphasis on acid conditions. Water, Air and Soil Pollution, 66: 289-314.

Golder Associates Ltd. 2008. Report on Pennask Creek Tributary Acid Rock Drainage (ARD) Remediation Okanagan Highway 97C Merritt to Peachland, BC. Report Number 07-14140018, Submitted to BC Ministry of Transportation, Kamloops.

Golder Associates Ltd. 2009. Annual Report on 2008 Pennask Creek Tributary Acid Rock Drainage (ARD/ML) Remediation Okanagan Highway 97C: Merritt to Peachland, BC. Report Number 08-1476-0039, Submitted to BC Ministry of Transportation and Infrastructure, Kamloops.

Grande, J.A., Beltran, R., Sainz, A. Santos, J.C., de la Torre, M.L. and Borrego, J. 2005. Acid mine drainage and acid rock drainage processes in the environment of Herrerias Mine (Iberian Pyrite Belt, Huelva-Spain) and impact on the Andevalo Dam. Environmental Geology, 47: 185-196. 
Gray, N.F. 1996. Field assessment of acid mine drainage contamination in surface and ground water. Environmental Geology, 27: 358-361.

Gray, N.F. 1997. Environmental impact and remediation of acid mine drainage: A management problem. Environmental Geology, 30: 62-71.

Griffith, M.B., Lazorchak, J.M., and Herlihy, A.T. 2004. Relationships among exceedances of metals criteria, the results of ambient bioassays, and community metrics in mining-impacted streams. Environmental Toxicology and Chemistry, 23(7): 1786-1795.

Grunenberg, P. and Tomlinson, S.S. 2001. Results of geological, geophysical, and geochemical surveys conducted on the Pennask Creek acid rock drainage project: Highway 97C, Region 2. Ministry of Transportation, Geotechnical and Materials Engineering. File No: 3330027/s0180.

Hare, L. 1992. Aquatic insects and trace metals: bioavailability, bioaccumulation, and toxicity. Critical Reviews in Toxicology, 22(5-6): 327-369.

Horvath, S. (editor). 2009. British Columbia Environmental Laboratory Manual. Water and Air Monitoring and Reporting, Environmental Quality Branch, Ministry of Environment, Victoria, BC, Canada. Available from: http://www.env.gov.bc.ca/epd/wamr/labsys/lab-man09/index.htm. [Accessed 24 August 2009].

Jia, W. 2005. Laboratory study of the coating method to control ARD generation. M.A.Sc. Thesis. The University of British Columbia: Canada.

Jeffree, R.A., Twinning, J.R., Thomson, J. 2001. Recovery of fish communities in the Finniss River, Northern Australia following remediation of the Rum Jungle uranium/copper mine site. Environmental Science and Technology, 35: 2932-2941.

Kimball, B.A., Callender, E. and Axtmann, E.V. 1995. Effects of colloids on metal transport in a river receiving acid mine drainage, upper Arkansas River, Colorado, U.S.A. Applied Geochemistry, 10: 285-306.

Lacelle, D., Doucet, A., Clark, I.D., Lauriol, B. 2007. Acid generation and seasonal recycling in disturbed permafrost near Eagle Plains, northern Yukon Territory, Canada. Chemical Geology, 243: 157-177.

Letterman, R.D. and Mitsch, W.J. 1978. Impact of mine drainage on a mountain stream in Pennsylvania. Environmental Pollution, 17: 53-73.

Li, L.Y. 2006. Pre-construction Water Quality Monitoring for the Trial System at Pennask Creek, Acid Rock Drainage (ARD) Generated Site, Highway 97C June - October 2005. Project \# 5572307, Submitted to Ministry of Transportation - Engineering Branch, Victoria.

Li, L.Y. 2007. Water Quality Monitoring for the Trial System for Acid Rock Drainage (ARD) Remediation (Highway 97C: Summer 2006). Project \# 5509605, Submitted to Ministry of Transportation - Engineering Branch, Victoria. 
Li, L.Y., Hall, K., Yuan, Y., Mattu, G., McCallum, D. and Chen, M. 2009. Mobility and bioavailability of trace metals in the water-sediment system of the highly urbanized Brunette watershed. Water, Air, and Soil Pollution, 197: 249-266.

Mathews, R.C. Jr. and Morgan, E.L. 1982. Toxicity of Anakeesta Formation leachates to shovelnosed salamander, Great Smoky Mountains National Park. Journal of Environmental Quality, 11(1): 102-106.

McConnell, J.W. 2002. Stream-water geochemistry as a guide to sources of acid-mine drainage in the former Rambler Mines area. Current Research: Newfoundland Department of Mines and Energy. Geological Survey, Report 02-1: 277-287.

McIntyre, J.K., Baldwin, D.H., Meador, J.P. and Scholz, N.L. 2008. Chemosensory deprivation in juvenile coho salmon exposed to dissolved copper under varying water chemistry conditions. Environmental Science and Technology, 42(4): 1352-1358.

McKnight, D.M. and Bencala, K.E. 1990. The chemistry of iron, aluminum, and dissolved organic material in three acidic, metal-enriched, mountain streams, as controlled by watershed and in-stream processes. Water Resources Research, 26(12): 3087-3100.

Morin, K.A., and Hutt, N.M. 2003. Pennask Creek Area of Highway 97C - Assessment and Prediction of Acid Rock Drainage (ARD) and Metal Leaching (ML), and Best Options for Control. Report to the Ministry of Transportation.

Morin, K.A. and Hutt, N.M. 2007. Highway 97C Road-Cut Environmental Prosecution Near Pennask Creek. MDAG.com Internet Case Study 27. Available from http://www.mdag.com/case_studies/cs27.html. [Accessed 11 June 2009].

Mortula, M., Bard, S.M., Walsh, M.E. and Gagnon, G.A. 2009. Aluminum toxicity and ecological risk assessment of dried alum residual into surface water disposal. Canadian Journal of Civil Engineering, 36: 127-136.

Munk, L.A., Faure, G., Pride, D.E., and Bigham, J.M. 2002. Sorption of trace metals to an aluminum precipitate in a stream receiving acid rock-drainage; Snake River, Summit County, Colorado. Applied Geochemistry, 17: 421-430.

National Research Council of Canada. 2000. Marine Sediment Reference Materials for Trace Metals and other Constituents: MESS-3.

Orndorff, Z.W. and Daniels, W.L. 2004. Evaluation of acid-producing sulfidic materials in Virginia highway corridors. Environmental Geology, 46: 209-216.

Plafkin, J.L., Barbour, M.T., Porter, K.D., Gross, S.K. and Hughes, R.M. 1989. Rapid bioassessment protocols for use in streams and rivers: Benthic macroinvertebrates and fish. U.S. Environmental Protection Agency, Office of Water Regulations and Standards, Washington, D.C. EPA 440-4-89-001.

Risso-de Faverney, C., Devaux, A., Lafaurie, M., Girard, J.P., Bailly, B. and Rahmani, R. 2001. Cadmium induces apoptosis and genotoxicity in rainbow trout hepatocytes through generation of reactive oxygen species. Aquatic Toxicology, 53: 65-76. 
Sanchez-España, J., López, E., Santofimia, E., Aduvire, O., Reyes, J., Berettino, D. 2005. Acid mine drainage in the Iberian Pyrite Belt (Odiel river watershed, Huelva, SW Spain): Geochemistry, mineralogy and environmental implications. Applied Geochemistry, 20:13201356.

Sorensen, E.M. 1991. Metal Poisoning in Fish. Boca Raton, USA: CRC Press, Inc.

Soucek, D.J., Cherry, D.S., Currie, R.J., Latimer, H.A. and Trent, G.C. 2000a. Laboratory to field validation in an integrative assessment of an acid mine drainage-impacted watershed. Environmental Toxicology and Chemistry, 19(4): 1036-1043.

Soucek, D.J., Cherry, D.S. and Trent, G.C. 2000b. Relative acute toxicity of acid mine drainage water column and sediments to Daphnia magna in the Puckett's Creek watershed, Virginia, USA. Archives of Environmental Contamination and Toxicology, 38: 305-310.

Todd, A.S., McKnight, D.M., Jaros, C.L. and Marchitto, T.M. 2007. Effects of acid rock drainage on stocked rainbow trout (Oncorhynchus mykiss): an in-situ, caged fish experiment. Environmental Monitoring and Assessment, 130: 111-127.

Trois, C., Marcello, A., Pretti, S., Trois, P. and Rossi, G. 2007. The environmental risk posed by small dumps of complex arsenic, antimony, nickel and cobalt sulphides. Journal of Geochemical Exploration, 92(1): 83-95.

Verb, R.G. and Vis, M.L. 2000. Comparison of benthic diatom assemblages from streams draining abandoned and reclaimed coal mines and non-impacted sites. Journal of the North American Benthological Society, 19: 274-288.

Wang, W. 1987. Factors affecting metal toxicity to (and accumulation by) aquatic organisms Overview. Environment International, 13(6): 437-457.

Weiner, G.S., Schreck, C.B. and Li, H.W. 1986. Effects of low pH on reproduction of rainbow trout. Transactions of the American Fisheries Society, 115: 75-82.

Witters, H.E., Van Puymbroeck, S., Stouthart, A.J.H.X. and Wendelaar-Bonga, S.E. 1996. Physicochemical changes of aluminum in mixing zones: mortality and physiological disturbances in brown trout (Salmo trutta). Environmental Toxicology and Chemistry, 15: 986-996.

Wright, D.A. and Welbourn, P. 2002. Environmental Toxicology. Cambridge University Press, Cambridge, U.K.

Wu, P., Tang, C., Liu, C., Zhu, L., Pei, T.Q., and Feng, L. 2009. Geochemical distribution and removal of $\mathrm{As}, \mathrm{Fe}, \mathrm{Mn}$ and $\mathrm{Al}$ in a surface water system affected by acid mine drainage at a coalfield in Southwestern China. Environmental Geology, 57:1457-1467.

Xstrata Copper (Canada Division). No Date. Brenda Mines: Closed Site. Available from: http://www.brendamines.ca/. [Accessed 6 July 2009]. 
Zajdlik, B.A., Doe, K.G. and Porebski, L.M. 2000. Report on biological toxicity tests using pollution gradient studies: Sydney Harbour. Environment Canada: Marine Environment Division, Ottawa. Report EPS 3/AT/2. Available from:

http://www.ec.gc.ca/seadisposal/docs/sydney_harbour_e.pdf. [Accessed 26 June 2010]. 


\section{APPENDIX A: WATER AND SEDIMENT DATA TABLES}

Table A1: General water quality characteristics for July water samples

\begin{tabular}{|c|c|c|c|c|c|c|c|c|c|}
\hline \multirow{2}{*}{ Parameter } & \multirow{2}{*}{ Units } & \multicolumn{8}{|c|}{ Sample ID } \\
\hline & & H1A & H1B & $\mathbf{H 2}$ & H3 & P1 & $\mathbf{P 2}$ & P3 & $\mathbf{P 4}$ \\
\hline Temperature & ${ }^{\circ} \mathrm{C}$ & - & 7.3 & 8.3 & 8.4 & 14.9 & 13.7 & 11.8 & 13.6 \\
\hline Dissolved Oxygen & $\mathrm{mg} / \mathrm{L}$ & - & 10.0 & 9.7 & 10.7 & 7.7 & 8.7 & 9.9 & 8.1 \\
\hline Turbidity & NTU & - & 0.4 & 2.6 & 3.2 & 0.5 & 0.8 & 0.4 & 0.6 \\
\hline pH (field) & $\mathrm{pH}$ & 7.0 & 6.7 & 6.3 & 6.6 & 6.6 & 7.2 & 7.2 & 7.0 \\
\hline $\mathrm{pH}(\mathrm{lab})$ & $\mathrm{pH}$ & 7.2 & 7.1 & 6.8 & 6.8 & 6.9 & 7.1 & 7.4 & 7.2 \\
\hline Specific Conductivity (field) & $\mu \mathrm{S} / \mathrm{cm}$ & 62.5 & 65.2 & 103.4 & 134.0 & 38.0 & 76.0 & 59.9 & 86.2 \\
\hline Specific Conductivity (lab) & $\mu \mathrm{S} / \mathrm{cm}$ & 75.4 & 81.1 & 126.1 & 148.7 & 43.6 & 68.0 & 59.0 & 82.6 \\
\hline Hardness & $\mathrm{mg} / \mathrm{L}\left(\mathrm{CaCO}_{3}\right)$ & 27.3 & 28.4 & 38.9 & 62.7 & 17.7 & 23.4 & 26.8 & 35.0 \\
\hline Total Alkalinity & $\mathrm{mg} / \mathrm{L}\left(\mathrm{CaCO}_{3}\right)$ & 47.7 & 46.4 & 36.6 & 23.9 & 33.9 & 37.6 & 48.5 & 49.1 \\
\hline Sulphate & $\mathrm{mg} / \mathrm{L}\left(\mathrm{SO}_{4}\right)$ & 19.8 & 24.9 & 47.7 & 76.8 & 11.0 & 14.2 & 12.4 & 23.9 \\
\hline
\end{tabular}

- not measured

Table A2: General water quality characteristics for September water samples

\begin{tabular}{|c|c|c|c|c|c|c|c|c|c|}
\hline \multirow{2}{*}{ Parameter } & \multirow{2}{*}{ Units } & \multicolumn{8}{|c|}{ Sample ID } \\
\hline & & H1 & H2 & H3 & P1 & P2 & P3 & $\mathbf{P 4}$ & P5 \\
\hline Temperature & ${ }^{\circ} \mathrm{C}$ & 7.1 & 6.5 & 5.5 & 5.5 & 7.0 & 5.0 & 7.0 & 8.5 \\
\hline Dissolved Oxygen & $\mathrm{mg} / \mathrm{L}$ & 13.4 & 13.5 & 12.3 & 11.0 & 12.0 & 12.5 & 11.6 & 11.0 \\
\hline Turbidity & NTU & 0.4 & 3.0 & 5.0 & 0.4 & 0.4 & 0.3 & 0.7 & 0.6 \\
\hline pH (field) & $\mathrm{pH}$ & 7.0 & 6.2 & 6.2 & 6.9 & 7.0 & 7.1 & 6.7 & 7.1 \\
\hline $\mathrm{pH}(\mathrm{lab})$ & $\mathrm{pH}$ & 7.1 & 6.4 & 6.3 & 6.9 & 7.0 & 7.1 & 6.8 & 7.3 \\
\hline Specific Conductivity (field) & $\mu \mathrm{S} / \mathrm{cm}$ & 81.5 & 170.0 & 304.0 & 54.0 & 128.0 & 76.8 & 147.4 & 117.0 \\
\hline Specific Conductivity (lab) & $\mu \mathrm{S} / \mathrm{cm}$ & 82.9 & 166.7 & 307.7 & 56.6 & 134.3 & 81.8 & 152.4 & 120.0 \\
\hline Hardness & $\mathrm{mg} / \mathrm{L}\left(\mathrm{CaCO}_{3}\right)$ & 28.7 & 49.4 & 88.3 & 21.5 & 35.1 & 31.6 & 48.6 & 43.4 \\
\hline Total Alkalinity & $\mathrm{mg} / \mathrm{L}\left(\mathrm{CaCO}_{3}\right)$ & 47.0 & 33.0 & 8.6 & 39.0 & 43.5 & 53.2 & 50.0 & 71.0 \\
\hline Sulphate & $\mathrm{mg} / \mathrm{L}\left(\mathrm{SO}_{4}\right)$ & 35.3 & 40.0 & 85.6 & 7.0 & 37.7 & 19.4 & 26.6 & 33.9 \\
\hline
\end{tabular}


Table A3: Total metal concentrations in July water samples

\begin{tabular}{|c|c|c|c|c|c|c|c|c|c|c|c|c|c|c|c|}
\hline \multirow{3}{*}{$\begin{array}{l}\text { Metal } \\
(\mathrm{mg} / \mathrm{L})\end{array}$} & \multicolumn{15}{|c|}{ Sample ID } \\
\hline & \multirow{2}{*}{ H1A } & \multicolumn{4}{|c|}{ H1B } & \multirow{2}{*}{$\mathbf{H} 2$} & \multicolumn{4}{|c|}{$\mathrm{H3}$} & \multirow[b]{2}{*}{ P1 } & \multirow{2}{*}{$\mathbf{P 2}$} & \multirow{2}{*}{$\mathbf{P 3}$} & \multirow{2}{*}{$\mathbf{P 4}$} & \multirow{2}{*}{ P5 } \\
\hline & & Rep. 1 & Rep. 2 & Rep. 3 & Mean & & Rep. 1 & Rep. 2 & Rep. 3 & Mean & & & & & \\
\hline Aluminum & 0.024 & 0.868 & 0.056 & 0.026 & 0.317 & 0.951 & 0.944 & 0.979 & 0.978 & 0.967 & 0.200 & 0.032 & $<0.02$ & 0.061 & - \\
\hline Arsenic & $<0.02$ & $<0.02$ & $<0.02$ & $<0.02$ & $<0.02$ & $<0.02$ & $<0.02$ & $<0.02$ & $<0.02$ & $<0.02$ & $<0.02$ & $<0.02$ & $<0.02$ & $<0.02$ & - \\
\hline Barium & $<0.003$ & $<0.003$ & $<0.003$ & $<0.003$ & $<0.003$ & $<0.003$ & 0.003 & 0.003 & 0.003 & 0.003 & 0.003 & 0.003 & $<0.003$ & $<0.003$ & - \\
\hline Beryllium & $<0.001$ & $<0.001$ & $<0.001$ & $<0.001$ & $<0.001$ & $<0.001$ & $<0.001$ & $<0.001$ & $<0.001$ & $<0.001$ & $<0.001$ & $<0.001$ & $<0.001$ & $<0.001$ & - \\
\hline Boron & $<0.02$ & $<0.02$ & $<0.02$ & $<0.02$ & $<0.02$ & $<0.02$ & $<0.02$ & $<0.02$ & $<0.02$ & $<0.02$ & $<0.02$ & $<0.02$ & $<0.02$ & $<0.02$ & - \\
\hline Cadmium & $<0.01$ & $<0.01$ & $<0.01$ & $<0.01$ & $<0.01$ & $<0.01$ & $<0.01$ & $<0.01$ & $<0.01$ & $<0.01$ & $<0.01$ & $<0.01$ & $<0.01$ & $<0.01$ & - \\
\hline Calcium & 9.104 & 9.990 & 9.287 & 9.062 & 9.446 & 12.130 & 15.960 & 15.900 & 16.600 & 16.153 & 5.081 & 6.477 & 9.302 & 11.000 & - \\
\hline Cobalt & $<0.005$ & $<0.005$ & $<0.005$ & $<0.005$ & $<0.005$ & $<0.005$ & 0.005 & 0.006 & 0.006 & 0.006 & $<0.005$ & $<0.005$ & $<0.005$ & $<0.005$ & - \\
\hline Copper & 0.028 & 0.037 & 0.026 & 0.021 & 0.028 & 0.036 & 0.039 & 0.031 & 0.031 & 0.034 & 0.030 & 0.017 & 0.024 & 0.017 & - \\
\hline Iron & 0.019 & 0.055 & 0.043 & 0.027 & 0.042 & 0.130 & 0.077 & 0.078 & 0.083 & 0.079 & 0.097 & 0.028 & 0.011 & 0.133 & - \\
\hline Magnesium & 1.014 & 1.160 & 1.082 & 1.056 & 1.099 & 2.125 & 3.614 & 3.602 & 3.763 & 3.660 & 1.152 & 1.492 & 0.779 & 1.464 & - \\
\hline Manganese & 0.004 & 0.016 & 0.015 & 0.017 & 0.016 & 0.185 & 0.346 & 0.353 & 0.357 & 0.352 & 0.006 & 0.005 & 0.003 & 0.039 & - \\
\hline Molybdenum & $<0.01$ & $<0.01$ & $<0.01$ & $<0.01$ & $<0.01$ & $<0.01$ & $<0.01$ & $<0.01$ & $<0.01$ & $<0.01$ & $<0.01$ & $<0.01$ & $<0.01$ & $<0.01$ & - \\
\hline Nickel & $<0.005$ & $<0.005$ & $<0.005$ & $<0.005$ & $<0.005$ & $<0.005$ & 0.011 & 0.011 & 0.013 & 0.012 & $<0.005$ & $<0.005$ & $<0.005$ & $<0.005$ & - \\
\hline Lead & $<0.02$ & $<0.02$ & $<0.02$ & $<0.02$ & $<0.02$ & $<0.02$ & $<0.02$ & $<0.02$ & $<0.02$ & $<0.02$ & $<0.02$ & $<0.02$ & $<0.02$ & $<0.02$ & - \\
\hline Selenium & $<0.05$ & $<0.05$ & $<0.05$ & $<0.05$ & $<0.05$ & $<0.05$ & $<0.05$ & $<0.05$ & $<0.05$ & $<0.05$ & $<0.05$ & $<0.05$ & $<0.05$ & $<0.05$ & - \\
\hline Thallium & $<0.05$ & $<0.05$ & $<0.05$ & $<0.05$ & $<0.05$ & $<0.05$ & $<0.05$ & $<0.05$ & $<0.05$ & $<0.05$ & $<0.05$ & $<0.05$ & $<0.05$ & $<0.05$ & - \\
\hline Zinc & $<0.01$ & $<0.01$ & $<0.01$ & $<0.01$ & $<0.01$ & 0.222 & 0.380 & 0.379 & 0.391 & 0.383 & $<0.01$ & $<0.01$ & $<0.01$ & $<0.01$ & - \\
\hline
\end{tabular}

- $\quad$ - not measured 
Table A4: Dissolved metal concentrations in July water samples

\begin{tabular}{|c|c|c|c|c|c|c|c|c|c|c|c|c|c|c|c|}
\hline \multirow{3}{*}{$\begin{array}{l}\text { Metal } \\
(\mathrm{mg} / \mathrm{L})\end{array}$} & \multicolumn{15}{|c|}{ Sample ID } \\
\hline & \multirow{2}{*}{ H1A } & \multicolumn{4}{|c|}{ H1B } & \multirow{2}{*}{$\mathbf{H} 2$} & \multicolumn{4}{|c|}{$\mathrm{H3}$} & \multirow{2}{*}{ P1 } & \multirow{2}{*}{$\mathbf{P 2}$} & \multirow{2}{*}{$\mathbf{P 3}$} & \multirow{2}{*}{ P4 } & \multirow{2}{*}{ P5 } \\
\hline & & Rep. 1 & Rep. 2 & Rep. 3 & Mean & & Rep. 1 & Rep. 2 & Rep. 3 & Mean & & & & & \\
\hline Aluminum & 0.028 & 0.023 & 0.031 & 0.032 & 0.029 & 0.289 & 2.455 & 1.351 & 1.079 & 1.628 & 0.040 & 0.272 & 0.021 & 1.672 & - \\
\hline Arsenic & $<0.02$ & $<0.02$ & $<0.02$ & $<0.02$ & $<0.02$ & $<0.02$ & $<0.02$ & $<0.02$ & $<0.02$ & $<0.02$ & $<0.02$ & $<0.02$ & $<0.02$ & $<0.02$ & - \\
\hline Barium & $<0.003$ & $<0.003$ & $<0.003$ & $<0.003$ & $<0.003$ & $<0.003$ & 0.004 & 0.005 & 0.005 & 0.004 & 0.003 & 0.008 & $<0.003$ & 0.003 & - \\
\hline Beryllium & $<0.001$ & $<0.001$ & $<0.001$ & $<0.001$ & $<0.001$ & $<0.001$ & $<0.001$ & $<0.001$ & $<0.001$ & $<0.001$ & $<0.001$ & $<0.001$ & $<0.001$ & $<0.001$ & - \\
\hline Boron & 0.048 & $<0.02$ & $<0.02$ & 0.051 & 0.031 & $<0.02$ & $<0.02$ & $<0.02$ & 0.029 & $<0.02$ & $<0.02$ & 0.014 & 0.038 & $<0.02$ & - \\
\hline Cadmium & $<0.001$ & $<0.001$ & $<0.001$ & $<0.001$ & $<0.001$ & $<0.001$ & $<0.001$ & $<0.001$ & $<0.001$ & $<0.001$ & $<0.001$ & $<0.001$ & $<0.001$ & $<0.001$ & - \\
\hline Calcium & .844 & 10.330 & 10.260 & 10.150 & 10.247 & 12.840 & 18.270 & 18.040 & 17.950 & 18.087 & 5.354 & 7.488 & 10.560 & 12.970 & - \\
\hline Cobalt & $<0.005$ & $<0.005$ & $<0.005$ & $<0.005$ & $<0.005$ & $<0.005$ & 0.006 & 0.006 & 0.005 & 0.006 & $<0.005$ & $<0.005$ & $<0.005$ & $<0.005$ & - \\
\hline Copper & 0.012 & 0.009 & 0.011 & 0.010 & 0.010 & 0.020 & 0.043 & 0.041 & 0.040 & 0.041 & 0.011 & 0.021 & 0.010 & 0.043 & - \\
\hline Iron & 0.037 & 0.031 & 0.042 & 0.043 & 0.039 & 0.111 & 0.107 & 0.437 & 0.133 & 0.226 & 0.088 & 0.047 & 0.047 & 0.134 & - \\
\hline Magnesium & 1.094 & 1.218 & 1.220 & 1.159 & 1.199 & 2.284 & 4.169 & 4.055 & 4.036 & 4.087 & 1.199 & 1.746 & 0.881 & 1.732 & - \\
\hline Manganese & 0.002 & 0.014 & 0.015 & 0.017 & 0.015 & 0.194 & 0.389 & 0.385 & 0.387 & 0.387 & 0.004 & 0.003 & 0.003 & 0.043 & - \\
\hline Molybdenum & $<0.01$ & $<0.01$ & $<0.01$ & $<0.01$ & $<0.01$ & $<0.01$ & $<0.01$ & $<0.01$ & $<0.01$ & $<0.01$ & $<0.01$ & $<0.01$ & $<0.01$ & $<0.01$ & - \\
\hline Nickel & $<0.005$ & $<0.005$ & $<0.005$ & $<0.005$ & $<0.005$ & $<0.005$ & 0.019 & 0.019 & 0.020 & 0.019 & $<0.005$ & $<0.005$ & $<0.005$ & $<0.005$ & - \\
\hline Lead & $<0.02$ & $<0.02$ & $<0.02$ & $<0.02$ & $<0.02$ & $<0.02$ & $<0.02$ & $<0.02$ & $<0.02$ & $<0.02$ & $<0.02$ & $<0.02$ & $<0.02$ & $<0.02$ & - \\
\hline Selenium & $<0.05$ & $<0.05$ & $<0.05$ & $<0.05$ & $<0.05$ & $<0.05$ & $<0.05$ & $<0.05$ & $<0.05$ & $<0.05$ & $<0.05$ & $<0.05$ & $<0.05$ & $<0.05$ & - \\
\hline Thallium & $<0.05$ & $<0.05$ & $<0.05$ & $<0.05$ & $<0.05$ & $<0.05$ & $<0.05$ & $<0.05$ & $<0.05$ & $<0.05$ & $<0.05$ & $<0.05$ & $<0.05$ & $<0.05$ & - \\
\hline Zinc & $<0.01$ & $<0.01$ & $<0.01$ & $<0.01$ & $<0.01$ & 0.242 & 0.454 & 0.453 & 0.461 & 0.456 & $<0.01$ & $<0.01$ & $<0.01$ & 0.018 & - \\
\hline
\end{tabular}

- $\quad$ not measured 
Table A5: Total metal concentrations in September water samples

\begin{tabular}{|c|c|c|c|c|c|c|c|c|c|c|c|c|c|c|}
\hline \multirow{3}{*}{$\begin{array}{l}\text { Metal } \\
(\mathrm{mg} / \mathrm{L})\end{array}$} & \multicolumn{14}{|c|}{ Sample ID } \\
\hline & \multirow{2}{*}{ H1 } & \multirow{2}{*}{$\mathbf{H} 2$} & \multirow{2}{*}{ H3 } & \multirow{2}{*}{ P1 } & \multirow{2}{*}{$\mathbf{P 2}$} & \multicolumn{4}{|c|}{ P3 } & \multicolumn{4}{|c|}{ P4 } & \multirow{2}{*}{ P5 } \\
\hline & & & & & & Rep. 1 & Rep. 2 & Rep. 3 & Mean & Rep. 1 & Rep. 2 & Rep. 3 & Mean & \\
\hline Aluminum & 0.058 & 1.621 & 2.281 & 0.060 & 0.037 & $<0.02$ & $<0.02$ & $<0.02$ & $<0.02$ & 0.056 & 0.057 & 0.056 & 0.057 & 0.029 \\
\hline Arsenic & $<0.02$ & $<0.02$ & $<0.02$ & $<0.02$ & $<0.02$ & $<0.02$ & $<0.02$ & $<0.02$ & $<0.02$ & $<0.02$ & $<0.02$ & $<0.02$ & $<0.02$ & $<0.02$ \\
\hline Barium & $<0.003$ & $<0.003$ & 0.006 & $<0.003$ & 0.008 & $<0.003$ & $<0.003$ & $<0.003$ & $<0.003$ & 0.004 & 0.004 & 0.004 & 0.004 & 0.003 \\
\hline Beryllium & $<0.001$ & $<0.001$ & $<0.001$ & $<0.001$ & $<0.001$ & $<0.001$ & $<0.001$ & $<0.001$ & $<0.001$ & $<0.001$ & $<0.001$ & $<0.001$ & $<0.001$ & $<0.001$ \\
\hline Boron & $<0.02$ & $<0.02$ & 0.032 & $<0.02$ & $<0.02$ & $<0.02$ & $<0.02$ & 0.100 & 0.100 & 0.031 & $<0.02$ & $<0.02$ & $<0.02$ & $<0.02$ \\
\hline Cadmium & $<0.001$ & $<0.001$ & $<0.001$ & $<0.001$ & $<0.001$ & $<0.001$ & $<0.001$ & $<0.001$ & $<0.001$ & $<0.001$ & $<0.001$ & $<0.001$ & $<0.001$ & $<0.001$ \\
\hline Calcium & 8.758 & 14.140 & 23.510 & 5.844 & 9.964 & 9.669 & 9.667 & 9.954 & 9.763 & 14.400 & 14.340 & 14.340 & 14.360 & 12.050 \\
\hline Cobalt & $<0.005$ & 0.008 & & $<0.005$ & $<0.005$ & $<0.005$ & $<0.005$ & $<0.005$ & $<0.005$ & $<0.005$ & $<0.005$ & $<0.005$ & $<0.005$ & $<0.005$ \\
\hline Copper & $<0.005$ & 0.026 & 0.037 & 0.006 & $<0.005$ & 0.007 & 0.007 & 0.005 & 0.006 & $<0.005$ & 0.009 & 0.012 & 0.008 & 0.006 \\
\hline Iron & $<0.01$ & 0.230 & 0.206 & 0.172 & 0.073 & 0.070 & 0.041 & 0.058 & 0.056 & 0.181 & 0.191 & 0.187 & 0.186 & 0.241 \\
\hline Magnesium & 1.273 & 3.039 & 6.131 & 1.403 & 2.420 & 0.914 & 0.921 & 0.947 & 0.927 & 2.413 & 2.400 & 2.394 & 2.402 & 2.451 \\
\hline Manganese & 0.019 & 0.321 & 0.657 & 0.007 & 0.006 & 0.003 & 0.003 & 0.003 & 0.003 & 0.066 & 0.067 & 0.066 & 0.066 & 0.012 \\
\hline Molybdenum & $<0.01$ & $<0.01$ & $<0.01$ & $<0.01$ & $<0.01$ & $<0.01$ & $<0.01$ & $<0.01$ & $<0.01$ & $<0.01$ & $<0.01$ & $<0.01$ & $<0.01$ & $<0.01$ \\
\hline Nickel & $<0.005$ & 0.005 & 0.051 & $<0.005$ & $<0.005$ & $<0.005$ & $<0.005$ & $<0.005$ & $<0.005$ & $<0.005$ & $<0.005$ & $<0.005$ & $<0.005$ & $<0.005$ \\
\hline Lead & $<0.02$ & $<0.02$ & $<0.02$ & $<0.02$ & $<0.02$ & $<0.02$ & $<0.02$ & $<0.02$ & $<0.02$ & $<0.02$ & $<0.02$ & $<0.02$ & $<0.02$ & $<0.02$ \\
\hline Selenium & $<0.05$ & $<0.05$ & $<0.05$ & $<0.05$ & $<0.05$ & $<0.05$ & $<0.05$ & $<0.05$ & $<0.05$ & $<0.05$ & $<0.05$ & $<0.05$ & $<0.05$ & $<0.05$ \\
\hline Thallium & $<0.05$ & $<0.05$ & $<0.05$ & $<0.05$ & $<0.05$ & $<0.05$ & $<0.05$ & $<0.05$ & $<0.05$ & $<0.05$ & $<0.05$ & $<0.05$ & $<0.05$ & $<0.05$ \\
\hline Zinc & $<0.01$ & 0.357 & 0.731 & $<0.01$ & $<0.01$ & $<0.01$ & $<0.01$ & $<0.01$ & $<0.01$ & 0.026 & 0.027 & 0.029 & 0.027 & $<0.01$ \\
\hline
\end{tabular}


Table A6: Dissolved metal concentrations in September water samples

\begin{tabular}{|c|c|c|c|c|c|c|c|c|c|c|c|c|c|c|}
\hline \multirow{3}{*}{$\begin{array}{l}\text { Metal } \\
(\mathrm{mg} / \mathrm{L})\end{array}$} & \multicolumn{14}{|c|}{ Sample ID } \\
\hline & \multirow{2}{*}{ H1 } & \multirow{2}{*}{$\mathrm{H} 2$} & \multirow{2}{*}{ H3 } & \multirow{2}{*}{ P1 } & \multirow{2}{*}{$\mathbf{P 2}$} & \multicolumn{4}{|c|}{ P3 } & \multicolumn{4}{|c|}{ P4 } & \multirow{2}{*}{ P5 } \\
\hline & & & & & & p. 1 & Rep.2 & Rep. 3 & Mean & & Rep. 2 & Rep. 3 & Mean & \\
\hline Alum & & & & & 0.024 & 0.020 & 0.034 & 0.037 & & & & 0.026 & & \\
\hline Arsenic & $<0.02$ & $<0.02$ & $<0.02$ & $<0.02$ & $<0.02$ & $<0.02$ & $<0.02$ & $<0.02$ & $<0.02$ & & $<0.02$ & $<0.02$ & & $<0.02$ \\
\hline Barium & $<0.003$ & $<0.003$ & 0.007 & 0.003 & 0.008 & $<0.003$ & $<0.003$ & $<0.003$ & $<0.003$ & 0.004 & 0.004 & 0.004 & 0.004 & 0.00 \\
\hline & .001 & $<0.001$ & $<0.001$ & $<0.001$ & $<0.001$ & $<0.001$ & $<0.001$ & $<0.001$ & $<0.001$ & $<0.001$ & $<0.001$ & $<0.001$ & $<0.001$ & $<0.001$ \\
\hline & & $<0.02$ & $<0.02$ & 0.027 & $<0.02$ & $<0.02$ & $<0.02$ & & & & & & & $<0.02$ \\
\hline & & $<0.001$ & $<0.001$ & & $<0.001$ & & & & & & & & & \\
\hline & & 14.55 & 24.660 & 6.11 & 9.973 & & 10.930 & & 10.9 & & & 15. & 15.2 & 12.9 \\
\hline & .005 & $<0.005$ & 0.005 & $<0.005$ & $<0.005$ & $<0.005$ & $<0.005$ & $<0.005$ & $<0.005$ & $<0.005$ & $<0.005$ & $<0.005$ & $<0.005$ & $<0.00$ \\
\hline & 005 & 0.017 & 0.025 & 0.005 & $<0.005$ & 0.010 & 0.011 & 0.014 & 0.011 & 06 & 0.0 & 0.008 & & 0.00 \\
\hline & & & & & & & & & & & & & & \\
\hline & & 3.162 & & & 2.471 & 1.058 & 1.058 & & & 2.609 & 2.568 & & & 2.676 \\
\hline & 0.020 & 0.328 & 0.681 & 0.006 & 0.005 & 0.003 & 0.003 & 0.003 & 0.003 & 0.068 & 0.068 & 0.068 & 0.068 & 0.013 \\
\hline Molybdenum & $<0.01$ & $<0.01$ & $<0.01$ & $<0.01$ & $<0.01$ & $<0.01$ & $<0.01$ & $<0.01$ & $<0.01$ & $<0.01$ & $<0.01$ & $<0.01$ & $<0.01$ & $<0.01$ \\
\hline Nickel & $<0.005$ & 0.007 & 0.059 & $<0.005$ & $<0.005$ & $<0.005$ & $<0.005$ & $<0.005$ & $<0.005$ & $<0.005$ & $<0.005$ & $<0.005$ & $<0.005$ & $<0.005$ \\
\hline & & $<0.02$ & $<0.02$ & & $<0.02$ & $<0.02$ & $<0.02$ & $<0.02$ & $<0.02$ & $<0.02$ & $<0.02$ & $<0.02$ & $<0.02$ & $<0.02$ \\
\hline & $<0.05$ & $<0.05$ & $<0.05$ & $<0.05$ & $<0.05$ & $<0.05$ & $<0.05$ & $<0.05$ & $<0.05$ & $<0.05$ & $<0.05$ & $<0.05$ & $<0.05$ & $<0.05$ \\
\hline & & $<0.05$ & $<0.05$ & & & & $<0.05$ & $<0.05$ & & & & $<0.05$ & & $<0.05$ \\
\hline Zinc & $<0.01$ & 0.383 & 0.795 & $<0.01$ & $<0.01$ & $<0.01$ & $<0.01$ & $<0.01$ & $<0.01$ & 0.034 & 0.035 & 0.034 & 0.034 & $<0.01$ \\
\hline
\end{tabular}


Table A7: General sediment characteristics for July samples

\begin{tabular}{llrrrrrrrr}
\hline \multirow{2}{*}{ Parameter } & \multirow{2}{*}{ Units } & \multicolumn{8}{c}{ Sample ID } \\
\cline { 3 - 9 } & & H1 & H2 & H3 & P1 & P2 & P3 & P4 & P5 \\
\hline $\mathrm{pH}$ & $\mathrm{pH}$ & 6.4 & 5.9 & 5.7 & 5.7 & 6.0 & 5.6 & 6.4 & - \\
Fines $(<63 \mathrm{um})$ Content in $<2 \mathrm{~mm}$ fraction & $\%$ & 17.7 & 4.4 & 8.7 & 2.3 & 1.8 & 3.7 & 1.1 & - \\
Total Organic Carbon $(<63 \mathrm{um})$ & $\%$ & 1.2 & 2.2 & 1.4 & 0.8 & 1.1 & 1.2 & 1.3 & - \\
Organic Matter Content $(<63 \mathrm{um})$ & $\%$ & 10.2 & 6.6 & 10.9 & 7.8 & 7.2 & 8.2 & 10.8 & - \\
\hline
\end{tabular}

- not measured

Table A8: General sediment characteristics for September samples

\begin{tabular}{llrrrrrrrr}
\hline \multirow{2}{*}{ Parameter } & \multirow{2}{*}{ Units } & \multicolumn{1}{c}{ Sample ID } \\
\cline { 3 - 9 } & & H1 & H2 & H3 & P1 & P2 & P3 & P4 & P5 \\
\hline $\mathrm{pH}$ & $\mathrm{pH}$ & 6.5 & 5.8 & 5.8 & 5.7 & 6.1 & 5.5 & 6.5 & 6.0 \\
Fines $(<63 \mathrm{um})$ Content in $<2 \mathrm{~mm}$ fraction & $\%$ & 30.8 & 3.9 & 31.4 & 6.0 & 1.7 & 10.3 & 5.0 & 2.0 \\
Total Organic Carbon $(<63 \mathrm{um})$ & $\%$ & 1.4 & 1.2 & 1.4 & 2.6 & 1.3 & 1.0 & 1.6 & 0.9 \\
Organic Matter Content $(<63 \mathrm{um})$ & $\%$ & 8.3 & 6.7 & 5.0 & 6.1 & 11.3 & 8.5 & 8.6 & 4.0 \\
\hline
\end{tabular}


Table A9: Total metal content of July sediment samples (strong acid leachable $-\mathrm{HNO}_{3(\mathrm{conc})}+\mathrm{HCl}_{(\mathrm{conc})}$ )

\begin{tabular}{|c|c|c|c|c|c|c|c|c|c|c|c|c|c|c|c|c|c|c|}
\hline \multirow{2}{*}{ Sample ID } & \multicolumn{18}{|c|}{ Metal Content (mg/kg, dry weight) } \\
\hline & Al & As & $\mathbf{B a}$ & $\mathbf{B e}$ & $\mathbf{B}$ & Cd & $\mathbf{C a}$ & Co & $\mathbf{C u}$ & $\mathbf{F e}$ & Mg & Mn & Mo & $\mathbf{N i}$ & $\mathbf{P b}$ & Se & $\mathbf{T l}$ & $\mathbf{Z n}$ \\
\hline H1-A & 17113.9 & 11.4 & 191.6 & $<0.05$ & $<1.0$ & $<0.05$ & 8019.8 & 16.3 & 40.8 & 20148.5 & 4836.1 & 1447.5 & 2.5 & 38.7 & 3.0 & $<2.5$ & $<2.5$ & 398.4 \\
\hline H1-B & 17349.1 & 11.7 & 191.1 & $<0.05$ & $<1.0$ & $<0.05$ & 8051.9 & 16.2 & 40.9 & 19905.7 & 4839.6 & 1440.1 & 2.4 & 37.0 & 3.3 & $<2.5$ & $<2.5$ & 399.4 \\
\hline $\mathrm{H} 1-\mathrm{C}$ & 16467.9 & 11.0 & 184.4 & $<0.05$ & $<1.0$ & $<0.05$ & 7619.3 & 15.6 & 39.3 & 19068.8 & 4583.9 & 1378.0 & 2.4 & 36.9 & 3.1 & $<2.5$ & $<2.5$ & 389.3 \\
\hline $\mathrm{H} 2-\mathrm{A}$ & 23277.2 & 6.5 & 124.8 & $<0.05$ & $<1.0$ & $<0.05$ & 8000.0 & 21.4 & 210.0 & 26000.0 & 6138.6 & 1000.0 & 2.2 & 33.4 & 7.8 & $<2.5$ & $<2.5$ & 529.7 \\
\hline $\mathrm{H} 2-\mathrm{B}$ & 23155.3 & 8.3 & 124.3 & $<0.05$ & $<1.0$ & $<0.05$ & 7835.0 & 21.5 & 207.2 & 25835.0 & 6087.4 & 997.1 & 2.2 & 33.8 & 8.6 & $<2.5$ & $<2.5$ & 522.8 \\
\hline $\mathrm{H} 2-\mathrm{C}$ & 24088.8 & 7.8 & 124.1 & $<0.05$ & $<1.0$ & $<0.05$ & 8149.5 & 21.9 & 213.9 & 25808.4 & 6229.0 & 1010.7 & 2.3 & 35.5 & 8.8 & $<2.5$ & $<2.5$ & 532.2 \\
\hline H3-A & 25828.6 & 7.2 & 95.1 & $<0.05$ & $<1.0$ & $<0.05$ & 4032.9 & 15.1 & 164.8 & 19509.5 & 3031.4 & 540.0 & 3.8 & 42.2 & 1.0 & $<2.5$ & $<2.5$ & 508.1 \\
\hline H3-B & 26117.6 & 7.4 & 96.4 & $<0.05$ & $<1.0$ & $<0.05$ & 4237.3 & 15.4 & 164.9 & 20019.6 & 3099.5 & 559.8 & 3.9 & 41.9 & 0.6 & $<2.5$ & $<2.5$ & 509.8 \\
\hline $\mathrm{H} 3-\mathrm{C}$ & 23004.8 & 8.0 & 100.2 & $<0.05$ & $<1.0$ & $<0.05$ & 4367.6 & 15.8 & 170.8 & 20304.8 & 3174.8 & 574.3 & 3.8 & 44.5 & 0.8 & $<2.5$ & $<2.5$ & 525.7 \\
\hline P1-A & 18485.6 & 1.6 & 181.9 & $<0.05$ & $<1.0$ & $<0.05$ & 5976.0 & 11.4 & 31.0 & 18370.2 & 5875.0 & 726.4 & 1.8 & 6.1 & 0.2 & $<2.5$ & $<2.5$ & 63.4 \\
\hline P1-B & & 1.3 & 184.3 & $<0.05$ & $<1.0$ & $<0.05$ & 5892.2 & 11.5 & 31.9 & 18392.2 & 5843.1 & 732.4 & 1.8 & 8.5 & 0.2 & $<2.5$ & $<2.5$ & 62.4 \\
\hline P1-C & 17623.8 & 1.7 & 175.2 & $<0.05$ & $<1.0$ & $<0.05$ & 5642.9 & 11.1 & 30.2 & 17766.7 & 5614.3 & 710.0 & 1.7 & 6.7 & 0.3 & $<2.5$ & $<2.5$ & 60.4 \\
\hline $\mathrm{P} 2-\mathrm{A}$ & 15024.3 & 2.2 & 163.3 & $<0.05$ & & $<0.05$ & & 9.7 & 21.8 & 19669.9 & 5145.6 & 1294.7 & 1.1 & 4.4 & 0.9 & $<2.5$ & $<2.5$ & 100.1 \\
\hline P2-B & 14543.7 & 2.2 & 161.7 & $<0.05$ & $<1.0$ & $<0.05$ & 5640.8 & 9.5 & 21.5 & 19480.6 & 5053.4 & 1278.2 & 1.0 & 4.0 & 0.6 & $<2.5$ & $<2.5$ & 98.8 \\
\hline $\mathrm{P} 2-\mathrm{C}$ & 15053.4 & 2.1 & 162.2 & $<0.05$ & $<1.0$ & $<0.05$ & 5456.3 & 9.4 & 21.5 & 19325.2 & 5014.6 & 1268.4 & 1.0 & 4.1 & 0.5 & $<2.5$ & $<2.5$ & 97.9 \\
\hline P3-A & 17153.8 & 12.1 & 148.3 & $<0.05$ & $<1.0$ & $<0.05$ & 6129.8 & 7.9 & 27.4 & 19326.9 & 4410.1 & 565.4 & 1.7 & 4.9 & 1.3 & $<2.5$ & $<2.5$ & 134.7 \\
\hline P3-B & 15890.0 & 12.2 & 150.7 & $<0.05$ & $<1.0$ & $<0.05$ & 6105.0 & 8.0 & 27.8 & 19665.0 & 4432.5 & 577.5 & 1.7 & 4.5 & 1.2 & $<2.5$ & $<2.5$ & 136.0 \\
\hline P3-C & 15552.9 & 11.9 & 145.9 & $<0.05$ & $<1.0$ & $<0.05$ & 6081.7 & 7.7 & 27.5 & 19259.6 & 4341.8 & 551.9 & 1.7 & 6.5 & 1.4 & $<2.5$ & $<2.5$ & 150.6 \\
\hline P4-A & 18887.3 & 22.0 & 169.4 & $<0.05$ & $<1.0$ & $<0.05$ & 7495.1 & 38.5 & 70.1 & 23142.2 & 4328.4 & 3030.9 & 3.0 & 76.0 & 1.6 & $<2.5$ & $<2.5$ & 727.5 \\
\hline P4-B & 19500.0 & 22.2 & 176.9 & $<0.05$ & $<1.0$ & $<0.05$ & 7764.4 & 39.1 & 73.2 & 23451.9 & 4448.1 & 3114.9 & 3.0 & 79.7 & 1.7 & $<2.5$ & $<2.5$ & 756.3 \\
\hline P4-C & 19480.0 & 21.4 & 174.0 & $<0.05$ & $<1.0$ & $<0.05$ & 7630.0 & 38.7 & 71.8 & 23535.0 & 4409.0 & 3084.5 & 3.0 & 77.8 & 1.3 & $<2.5$ & $<2.5$ & 746.0 \\
\hline Method Blank & 1.2 & 1.3 & $<0.15$ & $<0.05$ & $<1.0$ & $<0.05$ & $<0.05$ & $<0.25$ & $<0.25$ & 2.9 & $<0.05$ & $<0.05$ & $<0.5$ & $<0.25$ & $<0.1$ & $<2.5$ & $<2.5$ & $<0.5$ \\
\hline MESS-3 & 15280.0 & 14.5 & 286.0 & $<0.05$ & $<1.0$ & $<0.05$ & 12745.0 & 8.3 & 30.3 & 23585.0 & 10300.0 & 252.5 & 1.3 & 21.1 & 15.5 & $<2.5$ & $<2.5$ & 116.5 \\
\hline
\end{tabular}


Table A10: Total metal content of September sediment samples (strong acid leachable $-\mathbf{H N O}_{3(\text { conc })}+\mathbf{H C l}_{(\mathrm{conc})}$ )

\begin{tabular}{|c|c|c|c|c|c|c|c|c|c|c|c|c|c|c|c|c|c|c|}
\hline \multirow{2}{*}{ Sample ID } & \multicolumn{18}{|c|}{ Metal Content (mg/kg, dry weight) } \\
\hline & Al & As & $\mathbf{B a}$ & $\mathbf{B e}$ & $\mathbf{B}$ & Cd & $\mathbf{C a}$ & Co & $\mathbf{C u}$ & Fe & Mg & Mn & Mo & $\mathbf{N i}$ & $\mathbf{P b}$ & Se & $\mathbf{T l}$ & $\mathbf{Z n}$ \\
\hline H1-A & 17331.6 & 16.1 & 207.0 & $<0.05$ & $<1.0$ & $<0.05$ & 7918.4 & 15.6 & 49.1 & 22265.3 & 5693.9 & 1209.7 & 2.9 & 33.8 & 4.6 & $<2.5$ & $<2.5$ & 460.9 \\
\hline H1-B & 16651.5 & 15.2 & 197.1 & $<0.05$ & $<1.0$ & $<0.05$ & 7596.0 & 15.0 & 48.0 & 21505.1 & 5469.7 & 1159.6 & 2.7 & 31.7 & 4.5 & $<2.5$ & $<2.5$ & 439.4 \\
\hline $\mathrm{H} 1-\mathrm{C}$ & 17061.9 & 15.9 & 205.2 & $<0.05$ & $<1.0$ & $<0.05$ & 7799.0 & 15.7 & 50.9 & 22134.0 & 5623.7 & 1201.5 & 2.8 & 33.6 & 4.6 & $<2.5$ & $<2.5$ & 456.9 \\
\hline $\mathrm{H} 2-\mathrm{A}$ & 30372.4 & 4.1 & 132.1 & $<0.05$ & $<1.0$ & $<0.05$ & 8204.1 & 22.2 & 188.3 & 27423.5 & 6801.0 & 995.9 & 1.8 & 36.1 & 11.1 & $<2.5$ & $<2.5$ & 660.2 \\
\hline H2-B & 30990.0 & 3.8 & 134.5 & $<0.05$ & $<1.0$ & $<0.05$ & 8170.0 & 22.2 & 190.8 & 27125.0 & 6755.0 & 994.0 & 1.8 & 36.2 & 11.2 & $<2.5$ & $<2.5$ & 653.0 \\
\hline $\mathrm{H} 2-\mathrm{C}$ & 32181.0 & 4.3 & 134.2 & $<0.05$ & $<1.0$ & $<0.05$ & 8323.8 & 22.6 & 195.2 & 27090.5 & 6881.0 & 1021.4 & 1.9 & 38.3 & 11.4 & $<2.5$ & $<2.5$ & 662.4 \\
\hline H3-A & 22130.8 & 3.9 & 122.2 & $<0.05$ & $<1.0$ & $<0.05$ & 4536.4 & 14.3 & 132.9 & 18799.1 & 4099.1 & 537.4 & 2.0 & 23.7 & $<0.1$ & $<2.5$ & $<2.5$ & 395.3 \\
\hline H3-B & 21564.8 & 3.7 & 117.9 & $<0.05$ & $<1.0$ & $<0.05$ & 4400.0 & 13.7 & 128.1 & 18143.5 & 3932.4 & 512.5 & 1.8 & 22.1 & $<0.1$ & $<2.5$ & $<2.5$ & 380.7 \\
\hline $\mathrm{H} 3-\mathrm{C}$ & 22038.5 & 3.2 & 120.2 & $<0.05$ & $<1.0$ & $<0.05$ & 4537.5 & 14.1 & 131.7 & 18831.7 & 4092.8 & 535.6 & 1.8 & 23.0 & $<0.1$ & $<2.5$ & $<2.5$ & 389.4 \\
\hline P1-A & 16576.5 & 2.1 & 189.8 & $<0.05$ & $<1.0$ & $<0.05$ & 5780.6 & 10.3 & 36.4 & 21035.7 & 5571.4 & 496.0 & 1.4 & 5.5 & 0.8 & $<2.5$ & $<2.5$ & 54.0 \\
\hline P1-B & 16292.9 & 2.1 & 191.3 & $<0.05$ & $<1.0$ & $<0.05$ & 5782.8 & 10.1 & 36.9 & 20813.1 & 5550.5 & 464.8 & 1.5 & 5.3 & 0.5 & $<2.5$ & $<2.5$ & 54.3 \\
\hline P1-C & 16273.2 & 2.4 & 189.7 & $<0.05$ & $<1.0$ & $<0.05$ & 5659.8 & 10.0 & 36.8 & 20768.0 & 5515.5 & 460.6 & 1.4 & 4.9 & 0.8 & $<2.5$ & $<2.5$ & 54.3 \\
\hline P2-A & 16137.3 & 2.7 & 199.8 & $<0.05$ & $<1.0$ & $<0.05$ & 6539.2 & 18.4 & 23.2 & 24210.8 & 4733.8 & 2363.7 & 0.9 & 6.5 & 1.8 & $<2.5$ & $<2.5$ & 91.1 \\
\hline P2-B & 15905.0 & 2.4 & 197.9 & $<0.05$ & $<1.0$ & $<0.05$ & 6400.0 & 18.2 & 22.8 & 24195.0 & 4688.0 & 2351.5 & 1.0 & 5.9 & 1.7 & $<2.5$ & $<2.5$ & 90.9 \\
\hline P2-C & 15389.9 & 2.4 & 195.9 & $<0.05$ & $<1.0$ & $<0.05$ & 6275.2 & 17.9 & 22.3 & 23334.9 & 4591.7 & 2307.8 & 0.9 & 7.4 & 2.0 & $<2.5$ & $<2.5$ & 88.8 \\
\hline P3-A & 13989.8 & 9.3 & 155.2 & $<0.05$ & $<1.0$ & $<0.05$ & 5413.3 & 6.1 & 22.7 & 17306.1 & 3803.6 & 193.0 & 1.6 & 1.1 & 0.3 & $<2.5$ & $<2.5$ & 111.2 \\
\hline P3-B & 12974.2 & 9.6 & 158.7 & $<0.05$ & $<1.0$ & $<0.05$ & 5463.9 & 6.1 & 24.0 & 17226.8 & 3799.0 & 193.8 & 1.5 & 1.0 & 0.6 & $<2.5$ & $<2.5$ & 113.7 \\
\hline P3-C & 14343.4 & 9.7 & 161.7 & $<0.05$ & $<1.0$ & $<0.05$ & 5606.1 & 6.2 & 23.4 & 17494.9 & 3876.8 & 197.5 & 1.7 & 1.5 & 0.3 & $<2.5$ & $<2.5$ & 116.0 \\
\hline P4-A & 16489.7 & 10.1 & 154.8 & $<0.05$ & $<1.0$ & $<0.05$ & 6226.8 & 23.9 & 52.1 & 18541.2 & 4089.2 & 1657.2 & 1.4 & 35.9 & 0.3 & $<2.5$ & $<2.5$ & 534.5 \\
\hline P4-B & 16722.2 & 10.3 & 158.9 & $<0.05$ & $<1.0$ & $<0.05$ & 6338.4 & 24.6 & 51.7 & 18727.3 & 4162.1 & 1687.9 & 1.4 & 37.6 & 0.3 & $<2.5$ & $<2.5$ & 544.4 \\
\hline P4-C & 17509.6 & 9.9 & 157.7 & $<0.05$ & $<1.0$ & $<0.05$ & 6288.5 & 24.2 & 51.2 & 18375.0 & 4113.5 & 1663.9 & 1.4 & 38.1 & 0.5 & $<2.5$ & $<2.5$ & 541.8 \\
\hline P5-A & 10921.6 & $<1.0$ & 163.0 & $<0.05$ & $<1.0$ & $<0.05$ & 6044.1 & 9.3 & 16.5 & 15539.2 & 3419.1 & 485.8 & $<0.5$ & 4.5 & 0.8 & $<2.5$ & $<2.5$ & 328.9 \\
\hline P5-B & 11068.0 & $<1.0$ & 167.0 & $<0.05$ & $<1.0$ & $<0.05$ & 6029.1 & 9.3 & 16.6 & 15786.4 & 3484.0 & 490.8 & $<0.5$ & 5.0 & 1.0 & $<2.5$ & $<2.5$ & 333.9 \\
\hline P5-C & 11086.7 & $<1.0$ & 162.7 & $<0.05$ & $<1.0$ & $<0.05$ & 6081.6 & 9.4 & 16.4 & 15949.0 & 3482.1 & 484.6 & $<0.5$ & 4.1 & 0.7 & $<2.5$ & $<2.5$ & 326.8 \\
\hline Method Blank - A & 6.1 & $<1.0$ & $<0.15$ & $<0.05$ & $<1.0$ & $<0.05$ & $<0.05$ & $<0.25$ & $<0.25$ & 7.0 & $<0.05$ & $<0.05$ & $<0.5$ & $<0.25$ & $<0.1$ & $<2.5$ & $<2.5$ & $<2.5$ \\
\hline Method Blank - B & 3.1 & 1.0 & $<0.15$ & $<0.05$ & $<1.0$ & $<0.05$ & $<0.05$ & $<0.25$ & $<0.25$ & 1.5 & $<0.05$ & $<0.05$ & $<0.5$ & $<0.25$ & $<0.1$ & $<2.5$ & $<2.5$ & $<2.5$ \\
\hline Method Blank - C & 5.5 & $<1.0$ & $<0.15$ & $<0.05$ & $<1.0$ & $<0.05$ & $<0.05$ & $<0.25$ & $<0.25$ & 66.5 & $<0.05$ & $<0.05$ & 1.8 & $<0.25$ & $<0.1$ & $<2.5$ & $<2.5$ & $<2.5$ \\
\hline MESS 3 - A & 14833.3 & 13.4 & 293.1 & $<0.05$ & $<1.0$ & $<0.05$ & 13004.9 & 8.5 & 31.4 & 24362.7 & 10465.7 & 253.9 & 1.2 & 21.9 & 15.5 & $<2.5$ & $<2.5$ & 117.9 \\
\hline MESS 3 - B & 14908.2 & 12.8 & 287.4 & $<0.05$ & $<1.0$ & $<0.05$ & 12765.3 & 8.4 & 28.1 & 24352.0 & 10443.9 & 249.3 & 1.1 & 21.9 & 14.9 & $<2.5$ & $<2.5$ & 114.2 \\
\hline MESS 3 - C & 15586.7 & 12.7 & 272.8 & $<0.05$ & $<1.0$ & $<0.05$ & 12183.7 & 7.9 & 26.4 & 23632.7 & 10081.6 & 235.5 & 1.1 & 19.5 & 13.9 & $<2.5$ & $<2.5$ & 108.3 \\
\hline
\end{tabular}


Table A11: Extractable metal content of July sediment samples (weak acid leachable $-0.5 \mathrm{M}$ HCI)

\begin{tabular}{|c|c|c|c|c|c|c|c|c|c|c|c|c|c|c|c|c|c|c|}
\hline \multirow{2}{*}{ Sample ID } & \multicolumn{18}{|c|}{ Metal Content (mg/kg, dry weight) } \\
\hline & Al & As & $\mathbf{B a}$ & $\mathbf{B e}$ & B & Cd & $\mathbf{C a}$ & Co & $\mathrm{Cu}$ & Fe & Mg & Mn & Mo & $\mathbf{N i}$ & $\mathbf{P b}$ & Se & $\mathbf{T l}$ & Zn \\
\hline H1-A & 2432.7 & 1.8 & 55.4 & 0.1 & $<1.0$ & $<0.1$ & 2866.3 & 5.4 & 10.7 & 3327.9 & 642.8 & 574.0 & $<0.5$ & 9.7 & 1.2 & $<2.5$ & $<2.5$ & 124.0 \\
\hline H1-B & 2176.2 & 1.7 & 50.8 & 0.1 & $<1.0$ & $<0.1$ & 2582.2 & 4.9 & 9.8 & 3104.0 & 581.5 & 524.0 & $<0.5$ & 8.7 & 1.0 & $<2.5$ & $<2.5$ & 114.8 \\
\hline $\mathrm{H} 1-\mathrm{C}$ & 2249.0 & 1.7 & 51.2 & 0.1 & $<1.0$ & $<0.1$ & 2643.0 & 5.0 & 9.9 & 3180.0 & 592.8 & 535.6 & $<0.5$ & 8.7 & 1.0 & $<2.5$ & $<2.5$ & 115.8 \\
\hline $\mathrm{H} 2-\mathrm{A}$ & 6307.8 & 1.6 & 21.8 & 0.3 & $<1.0$ & $<0.1$ & 2134.3 & 6.7 & 76.2 & 4246.1 & 564.9 & 343.4 & $<0.5$ & 7.9 & 2.9 & $<2.5$ & $<2.5$ & 177.6 \\
\hline $\mathrm{H} 2-\mathrm{B}$ & 3476.5 & 1.5 & 21.8 & 0.3 & $<1.0$ & $<0.1$ & 2169.6 & 6.9 & 75.8 & 4302.9 & 583.9 & 348.7 & $<0.5$ & 7.9 & 3.0 & $<2.5$ & $<2.5$ & 178.1 \\
\hline $\mathrm{H} 2-\mathrm{C}$ & 6146.6 & 1.5 & 20.9 & 0.3 & $<1.0$ & $<0.1$ & 2090.3 & 6.6 & 72.9 & 4181.6 & 553.8 & 338.1 & $<0.5$ & 7.6 & 2.8 & $<2.5$ & $<2.5$ & 172.5 \\
\hline $\mathrm{H} 3-\mathrm{A}$ & 6032.2 & 1.5 & 18.5 & 0.3 & $<1.0$ & $<0.1$ & 1248.2 & 5.0 & 62.2 & 4211.1 & 263.5 & 194.0 & $<0.5$ & 12.9 & 0.3 & $<2.5$ & $<2.5$ & 175.9 \\
\hline H3-B & 6014.9 & 1.4 & 18.5 & 0.3 & $<1.0$ & $<0.1$ & 1253.7 & 5.0 & 62.4 & 4199.0 & 263.9 & 197.1 & $<0.5$ & 13.0 & 0.2 & $<2.5$ & $<2.5$ & 176.8 \\
\hline $\mathrm{H} 3-\mathrm{C}$ & 5999.0 & 1.4 & 18.4 & 0.3 & $<1.0$ & $<0.1$ & 1250.7 & 5.0 & 61.8 & 4209.0 & 261.2 & 193.5 & $<0.5$ & 12.9 & 0.3 & $<2.5$ & $<2.5$ & 175.4 \\
\hline P1-A & 2534.0 & $<1.0$ & 53.6 & $<0.05$ & $<1.0$ & $<0.1$ & 1793.3 & 2.7 & 7.3 & 3125.4 & 877.7 & 263.5 & $<0.5$ & $<\mathrm{DL}$ & 0.4 & $<2.5$ & $<2.5$ & 12.5 \\
\hline P1-B & 2546.3 & $<1.0$ & 50.6 & $<0.05$ & $<1.0$ & $<0.1$ & 1677.6 & 2.6 & 6.8 & 3029.9 & 829.9 & 247.6 & $<0.5$ & $<\mathrm{DL}$ & 0.2 & $<2.5$ & $<2.5$ & 11.6 \\
\hline $\mathrm{P} 1-\mathrm{C}$ & 2585.1 & $<1.0$ & 50.2 & $<0.05$ & $<1.0$ & $<0.1$ & 1685.1 & 2.6 & 6.8 & 3044.6 & 839.3 & 249.5 & $<0.5$ & $<\mathrm{DL}$ & 0.3 & $<2.5$ & $<2.5$ & 11.5 \\
\hline P2-A & 2236.8 & $<1.0$ & 53.3 & $<0.05$ & $<1.0$ & $<0.1$ & 1925.4 & 2.4 & 4.7 & 3868.7 & 705.4 & 521.6 & $<0.5$ & $<\mathrm{DL}$ & 0.5 & $<2.5$ & $<2.5$ & 28.8 \\
\hline P2-B & 2101.0 & $<1.0$ & 48.5 & $<0.05$ & $<1.0$ & $<0.1$ & 1795.1 & 2.3 & 4.3 & 3666.0 & 665.3 & 488.5 & $<0.5$ & $<\mathrm{DL}$ & 0.4 & $<2.5$ & $<2.5$ & 26.0 \\
\hline $\mathrm{P} 2-\mathrm{C}$ & 2039.2 & $<1.0$ & 47.5 & $<0.05$ & $<1.0$ & $<0.1$ & 1750.8 & 2.3 & 4.2 & 3635.2 & 645.7 & 480.4 & $<0.5$ & $<\mathrm{DL}$ & 0.4 & $<2.5$ & $<2.5$ & 25.5 \\
\hline P3-A & 2685.1 & 1.8 & 44.6 & $<0.05$ & $<1.0$ & $<0.1$ & 2012.9 & 1.6 & 7.1 & 3515.8 & 593.0 & 199.2 & $<0.5$ & $<\mathrm{DL}$ & 0.7 & $<2.5$ & $<2.5$ & 30.7 \\
\hline P3-B & 2539.5 & 1.8 & 41.8 & $<0.05$ & $<1.0$ & $<0.1$ & 1907.3 & 1.5 & 6.5 & 3359.0 & 567.5 & 189.5 & $<0.5$ & $<\mathrm{DL}$ & 0.7 & $<2.5$ & $<2.5$ & 28.8 \\
\hline P3-C & 2519.6 & 1.7 & 40.9 & $<0.05$ & $<1.0$ & $<0.1$ & 1887.3 & 1.5 & 6.4 & 3345.1 & 551.2 & 184.8 & $<0.5$ & $<\mathrm{DL}$ & 0.7 & $<2.5$ & $<2.5$ & 28.5 \\
\hline P4-A & 3607.0 & 3.0 & 49.3 & 0.2 & $<1.0$ & 4.0 & 2465.7 & 14.2 & 23.3 & 4585.1 & 430.2 & 1091.5 & $<0.5$ & 27.1 & 0.5 & $<2.5$ & $<2.5$ & 247.1 \\
\hline P4-B & 3619.0 & 2.9 & 48.6 & 0.2 & $<1.0$ & 4.0 & 2493.0 & 14.1 & 23.0 & 4610.0 & 428.5 & 1097.0 & $<0.5$ & 26.7 & 0.5 & $<2.5$ & $<2.5$ & 244.0 \\
\hline P4-C & 3764.9 & 2.9 & 51.1 & 0.2 & $<1.0$ & 4.4 & 2572.7 & 14.7 & 24.2 & 4662.4 & 444.3 & 1120.0 & $<0.5$ & 28.2 & 0.5 & $<2.5$ & $<2.5$ & 254.3 \\
\hline M. Blank A & $<1.0$ & $<1.0$ & $<0.15$ & $<0.05$ & $<1.0$ & $<0.1$ & $<0.05$ & $<0.25$ & $<0.25$ & 1.4 & $<0.05$ & $<0.05$ & $<0.5$ & $<0.25$ & $<0.1$ & $<2.5$ & $<2.5$ & $<0.5$ \\
\hline M. Blank B & $<1.0$ & $<1.0$ & $<0.15$ & $<0.05$ & $<1.0$ & $<0.1$ & $<0.05$ & $<0.25$ & $<0.25$ & $<0.5$ & $<0.05$ & $<0.05$ & $<0.5$ & $<0.25$ & $<0.1$ & $<2.5$ & $<2.5$ & $<0.5$ \\
\hline MESS 3 - A & 828.3 & $<1.0$ & 9.5 & 0.1 & $<1.0$ & $<0.1$ & 5144.7 & 1.3 & 6.5 & 3220.4 & 2550.5 & 63.0 & $<0.5$ & 1.0 & 5.0 & $<2.5$ & $<2.5$ & 20.6 \\
\hline MESS 3 - B & 804.0 & $<1.0$ & 9.4 & 0.1 & $<1.0$ & $<0.1$ & 4975.1 & 1.3 & 6.3 & 3165.2 & 2519.4 & 61.3 & $<0.5$ & 0.8 & 4.9 & $<2.5$ & $<2.5$ & 19.8 \\
\hline
\end{tabular}


Table A12: Extractable metal content of September sediment samples (weak acid leachable - $0.5 \mathrm{M}$ HCl)

\begin{tabular}{|c|c|c|c|c|c|c|c|c|c|c|c|c|c|c|c|c|c|c|}
\hline \multirow{2}{*}{ Sample ID } & \multicolumn{18}{|c|}{ Metal Content (mg/kg, dry weight) } \\
\hline & Al & As & $\mathbf{B a}$ & $\mathbf{B e}$ & B & Cd & $\mathbf{C a}$ & Co & $\mathrm{Cu}$ & $\mathbf{F e}$ & Mg & Mn & Mo & $\mathbf{N i}$ & $\mathbf{P b}$ & Se & Tl & Zn \\
\hline H1-A & 1739.9 & 1.7 & 43.8 & 0.1 & $<1.0$ & $<0.05$ & 2225.6 & 4.2 & 10.0 & 2552.7 & 495.0 & 405.7 & $<0.5$ & 7.8 & 1.0 & $<2.5$ & $<2.5$ & 128.9 \\
\hline H1-B & 1773.0 & 1.8 & 45.7 & 0.1 & $<1.0$ & $<0.05$ & 2316.0 & 4.3 & 10.3 & 2669.0 & 515.5 & 420.2 & $<0.5$ & 8.1 & 1.1 & $<2.5$ & $<2.5$ & 134.2 \\
\hline $\mathrm{H} 1-\mathrm{C}$ & 1739.7 & 1.7 & 44.2 & 0.1 & $<1.0$ & $<0.05$ & 2229.1 & 4.2 & 10.0 & 2557.8 & 491.5 & 406.8 & $<0.5$ & 7.7 & 1.0 & $<2.5$ & $<2.5$ & 130.4 \\
\hline $\mathrm{H} 2-\mathrm{A}$ & 8953.3 & 1.0 & 18.2 & 0.3 & $<1.0$ & $<0.05$ & 1970.6 & 6.4 & 60.7 & 3548.2 & 640.8 & 318.2 & $<0.5$ & 7.4 & 3.2 & $<2.5$ & $<2.5$ & 212.7 \\
\hline H2-B & 8710.6 & $<1.0$ & 17.7 & 0.3 & $<1.0$ & $<0.05$ & 1933.7 & 6.3 & 60.5 & 3462.3 & 631.0 & 313.1 & $<0.5$ & 7.2 & 2.9 & $<2.5$ & $<2.5$ & 211.3 \\
\hline $\mathrm{H} 2-\mathrm{C}$ & 8876.1 & $<1.0$ & 17.5 & 0.4 & $<1.0$ & $<0.05$ & 1973.6 & 6.5 & 61.7 & 3506.6 & 613.1 & 319.6 & $<0.5$ & 7.4 & 3.2 & $<2.5$ & $<2.5$ & 212.1 \\
\hline H3-A & 6646.6 & $<1.0$ & 18.6 & 0.2 & $<1.0$ & $<0.05$ & 941.7 & 3.8 & 44.2 & 2540.8 & 344.3 & 160.4 & $<0.5$ & 5.0 & $<0.1$ & $<2.5$ & $<2.5$ & 119.0 \\
\hline H3-B & 6662.1 & $<1.0$ & 19.3 & 0.2 & $<1.0$ & $<0.05$ & 951.3 & 3.8 & 45.3 & 2586.2 & 352.6 & 161.7 & $<0.5$ & 5.0 & $<0.1$ & $<2.5$ & $<2.5$ & 122.2 \\
\hline $\mathrm{H} 3-\mathrm{C}$ & 6560.4 & $<1.0$ & 19.4 & 0.2 & $<1.0$ & $<0.05$ & 959.1 & 3.8 & 45.9 & 2573.3 & 354.2 & 162.6 & $<0.5$ & 5.0 & $<0.1$ & $<2.5$ & $<2.5$ & 123.2 \\
\hline P1-A & 1891.1 & $<1.0$ & 49.6 & $<0.05$ & $<1.0$ & $<0.05$ & 1387.1 & 1.8 & 7.4 & 2645.5 & 607.4 & 124.0 & $<0.5$ & $<0.25$ & 0.3 & $<2.5$ & $<2.5$ & 7.6 \\
\hline P1-A & 1959.8 & $<1.0$ & 52.2 & $<0.05$ & $<1.0$ & $<0.05$ & 1452.6 & 1.9 & 7.5 & 2782.5 & 644.0 & 130.6 & $<0.5$ & $<0.25$ & 0.4 & $<2.5$ & $<2.5$ & 7.8 \\
\hline $\mathrm{P} 1-\mathrm{C}$ & 1953.8 & $<1.0$ & 51.7 & $<0.05$ & $<1.0$ & $<0.05$ & 1436.2 & 1.9 & 7.5 & 2746.7 & 639.2 & 128.7 & $<0.5$ & $<0.25$ & 0.4 & $<2.5$ & $<2.5$ & 7.8 \\
\hline $\mathrm{P} 2-\mathrm{A}$ & 1646.5 & $<1.0$ & 58.7 & $<0.05$ & $<1.0$ & $<0.05$ & 1869.7 & 5.3 & 4.3 & 4892.9 & 440.1 & 816.8 & $<0.5$ & 0.0 & 1.3 & $<2.5$ & $<2.5$ & 19.6 \\
\hline P2-B & 1610.1 & $<1.0$ & 56.9 & $<0.05$ & $<1.0$ & $<0.05$ & 1865.7 & 5.2 & 4.2 & 4863.6 & 443.7 & 815.1 & $<0.5$ & 0.0 & 0.7 & $<2.5$ & $<2.5$ & 19.6 \\
\hline P2-C & 1617.4 & $<1.0$ & 56.7 & $<0.05$ & $<1.0$ & $<0.05$ & 1851.2 & 5.2 & 4.3 & 4772.0 & 437.8 & 805.7 & $<0.5$ & 0.0 & 0.7 & $<2.5$ & $<2.5$ & 19.4 \\
\hline P3-A & 2036.2 & 1.9 & 28.8 & $<0.05$ & $<1.0$ & $<0.05$ & 1512.6 & 0.9 & 5.1 & 2707.5 & 400.5 & 31.7 & $<0.5$ & $<0.25$ & 0.4 & $<2.5$ & $<2.5$ & 20.4 \\
\hline P3-B & 1994.9 & 1.9 & 27.7 & $<0.05$ & $<1.0$ & $<0.05$ & 1507.6 & 0.9 & 5.1 & 2683.2 & 398.8 & 31.6 & $<0.5$ & $<0.25$ & 0.3 & $<2.5$ & $<2.5$ & 20.1 \\
\hline P3-C & 191.0 & $<1.0$ & 2.5 & $<0.05$ & $<1.0$ & $<0.05$ & 144.2 & $<0.25$ & 0.5 & 257.0 & 37.0 & 3.0 & $<0.5$ & $<0.25$ & $<0.1$ & $<2.5$ & $<2.5$ & 1.9 \\
\hline P4-A & 2647.5 & 2.0 & 40.6 & 0.1 & $<1.0$ & 0.3 & 1763.6 & 7.6 & 15.0 & 2754.5 & 363.9 & 603.2 & $<0.5$ & 10.3 & $<0.1$ & $<2.5$ & $<2.5$ & 164.3 \\
\hline P4-B & 2635.6 & 1.8 & 39.3 & 0.1 & $<1.0$ & 0.3 & 1756.4 & 7.6 & 14.8 & 2729.7 & 359.9 & 599.6 & $<0.5$ & 10.0 & $<0.1$ & $<2.5$ & $<2.5$ & 159.5 \\
\hline P4-C & 2698.0 & 2.0 & 40.7 & 0.1 & $<1.0$ & 0.3 & 1777.0 & 7.6 & 15.2 & 2778.0 & 360.6 & 605.7 & $<0.5$ & 10.3 & $<0.1$ & $<2.5$ & $<2.5$ & 164.5 \\
\hline P5-A & 1097.5 & $<1.0$ & 39.1 & $<0.05$ & $<1.0$ & $<0.05$ & 1699.5 & 2.2 & 4.0 & 1614.9 & 358.1 & 155.3 & $<0.5$ & 1.1 & 0.5 & $<2.5$ & $<2.5$ & 108.0 \\
\hline P5-B & 1078.4 & $<1.0$ & 39.0 & $<0.05$ & $<1.0$ & $<0.05$ & 1670.6 & 2.1 & 4.0 & 1588.2 & 358.6 & 154.7 & $<0.5$ & 1.1 & 0.5 & $<2.5$ & $<2.5$ & 108.4 \\
\hline P5-C & 1128.4 & $<1.0$ & 40.3 & $<0.05$ & $<1.0$ & $<0.05$ & 1740.3 & 2.2 & 4.1 & 1656.7 & 375.3 & 162.1 & $<0.5$ & 1.2 & 0.5 & $<2.5$ & $<2.5$ & 111.6 \\
\hline M. Blank A & 4.5 & $<1.0$ & $<0.15$ & $<0.05$ & $<1.0$ & $<0.05$ & $<0.05$ & $<0.25$ & $<0.25$ & 4.5 & $<0.05$ & $<0.05$ & $<0.5$ & $<0.25$ & $<0.1$ & $<2.5$ & $<2.5$ & $<0.5$ \\
\hline M. Blank B & 1.3 & $<1.0$ & $<0.15$ & $<0.05$ & $<1.0$ & $<0.05$ & $<0.05$ & $<0.25$ & $<0.25$ & 1.4 & $<0.05$ & $<0.05$ & $<0.5$ & $<0.25$ & $<0.1$ & $<2.5$ & $<2.5$ & $<0.5$ \\
\hline M. Blank C & 1.0 & $<1.0$ & $<0.15$ & $<0.05$ & $<1.0$ & $<0.05$ & $<0.05$ & $<0.25$ & $<0.25$ & 0.8 & $<0.05$ & $<0.05$ & $<0.5$ & $<0.25$ & $<0.1$ & $<2.5$ & $<2.5$ & $<0.5$ \\
\hline MESS 3 & 651.4 & $<1.0$ & 8.9 & 0.1 & $<1.0$ & $<0.05$ & 4874.5 & 1.2 & 5.7 & 2831.6 & 2462.2 & 58.8 & $<0.5$ & $<0.25$ & 4.6 & $<2.5$ & $<2.5$ & 18.3 \\
\hline
\end{tabular}




\section{APPENDIX B: WILCOXON SIGNED-RANK TEST TABLES}

Table B1: Wilcoxon Signed-Rank Test $p$-values for water samples

\begin{tabular}{ll}
\hline Variable & $\boldsymbol{p}$-value \\
\hline pH (field) & 0.3750 \\
Specific Conductivity & $0.0156^{*}$ \\
Hardness & $0.0156^{*}$ \\
Total Alkalinity & 0.6108 \\
Sulphate & 0.2188 \\
Temperature & $0.0156^{*}$ \\
Dissolved Oxygen & $0.0156^{*}$ \\
Turbidity & 0.6108 \\
Total Al & 0.6875 \\
Total Cu & $0.0312^{*}$ \\
Total Fe & $0.0156^{*}$ \\
Total Mg & $0.0156^{*}$ \\
Total Mn & $0.0312^{*}$ \\
Total Ni & 0.1931 \\
Total $\mathrm{Zn}$ & 0.1050 \\
Dissolved Al & 0.2969 \\
Dissolved Cu & $0.0312^{*}$ \\
Dissolved Fe & 0.3750 \\
Dissolved $\mathrm{Mg}$ & $0.0156^{*}$ \\
Dissolved $\mathrm{Mn}$ & $0.0312^{*}$ \\
Dissolved Ni & 0.0931 \\
Dissolved $\mathrm{Zn}$ & 0.1050 \\
\hline
\end{tabular}

* significantly different $(p \leq 0.05)$
Table B2: Wilcoxon Signed-Rank Test $p$-values for sediment samples

\begin{tabular}{ll}
\hline Variable & $\boldsymbol{p}$-value \\
\hline $\mathrm{pH}$ & 0.7247 \\
Total Organic Carbon & 0.4436 \\
Organic Matter Content & 0.4688 \\
Total Al & 0.5781 \\
Total As & 0.4688 \\
Total Co & 0.2969 \\
Total Cu & 0.3750 \\
Total Fe & 0.8125 \\
Total $\mathrm{Mg}$ & 0.5781 \\
Total Mn & 0.2969 \\
Total Ni & 0.1562 \\
Total Pb & 0.4982 \\
Total $\mathrm{Zn}$ & 0.5781 \\
Extractable $\mathrm{Al}$ & 0.6875 \\
Extractable $\mathrm{As}$ & 0.1213 \\
Extractable $\mathrm{Co}$ & 0.2188 \\
Extractable $\mathrm{Cu}$ & 0.0898 \\
Extractable Fe & 0.1562 \\
Extractable $\mathrm{Mg}$ & 0.1094 \\
Extractable $\mathrm{Mn}$ & 0.2188 \\
Extractable $\mathrm{Ni}$ & 0.6140 \\
Extractable $\mathrm{Pb}$ & 1.0000 \\
Extractable $\mathrm{Zn}$ & 0.4688 \\
\hline
\end{tabular}


APPENDIX C: SAMPLE X-RAY DIFFRACTOGRAM

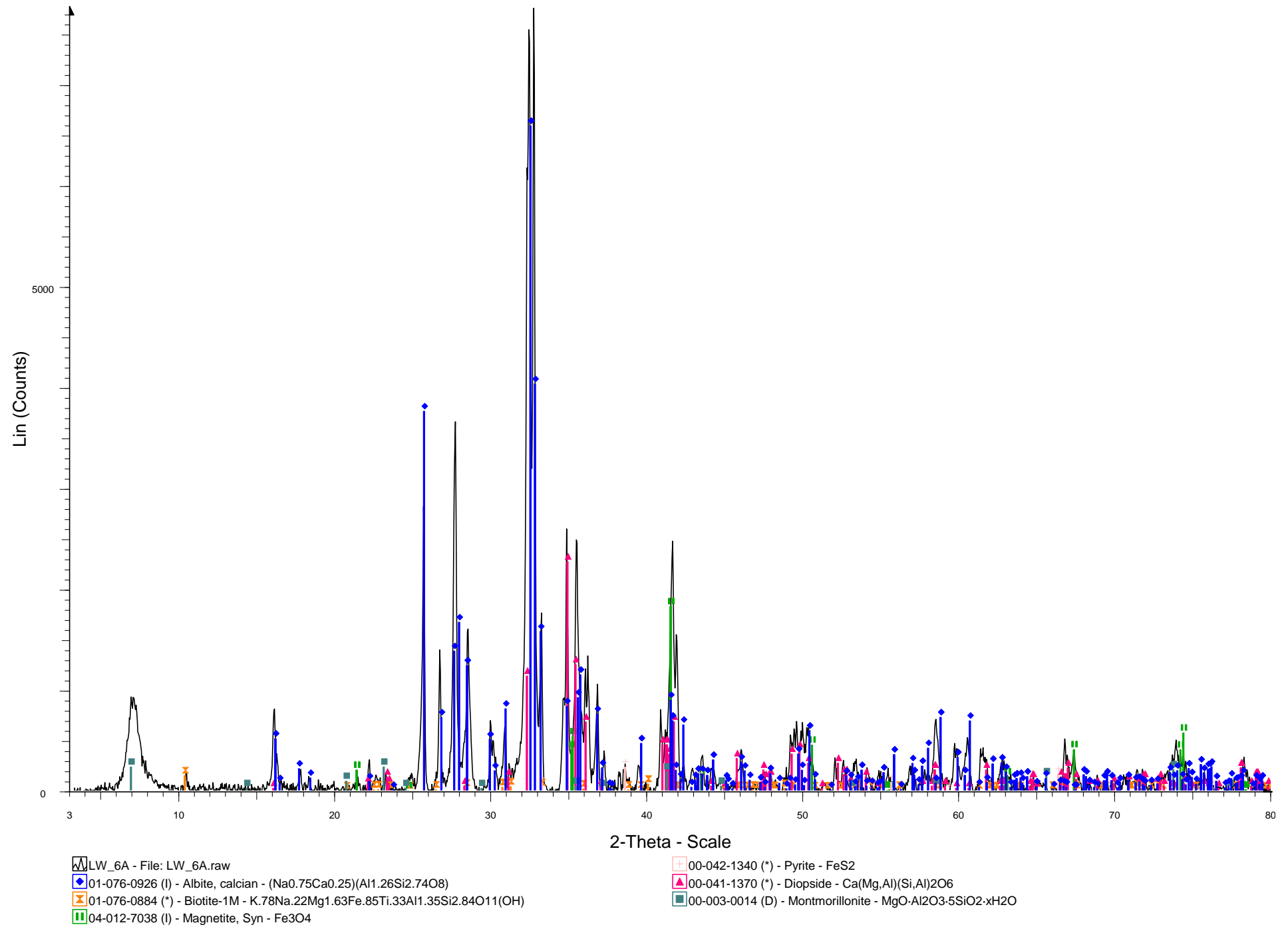

Figure C1: X-ray diffractogram of sample H1-A 


\section{APPENDIX D: QUALITY ASSURANCE/CONTROL DATA}

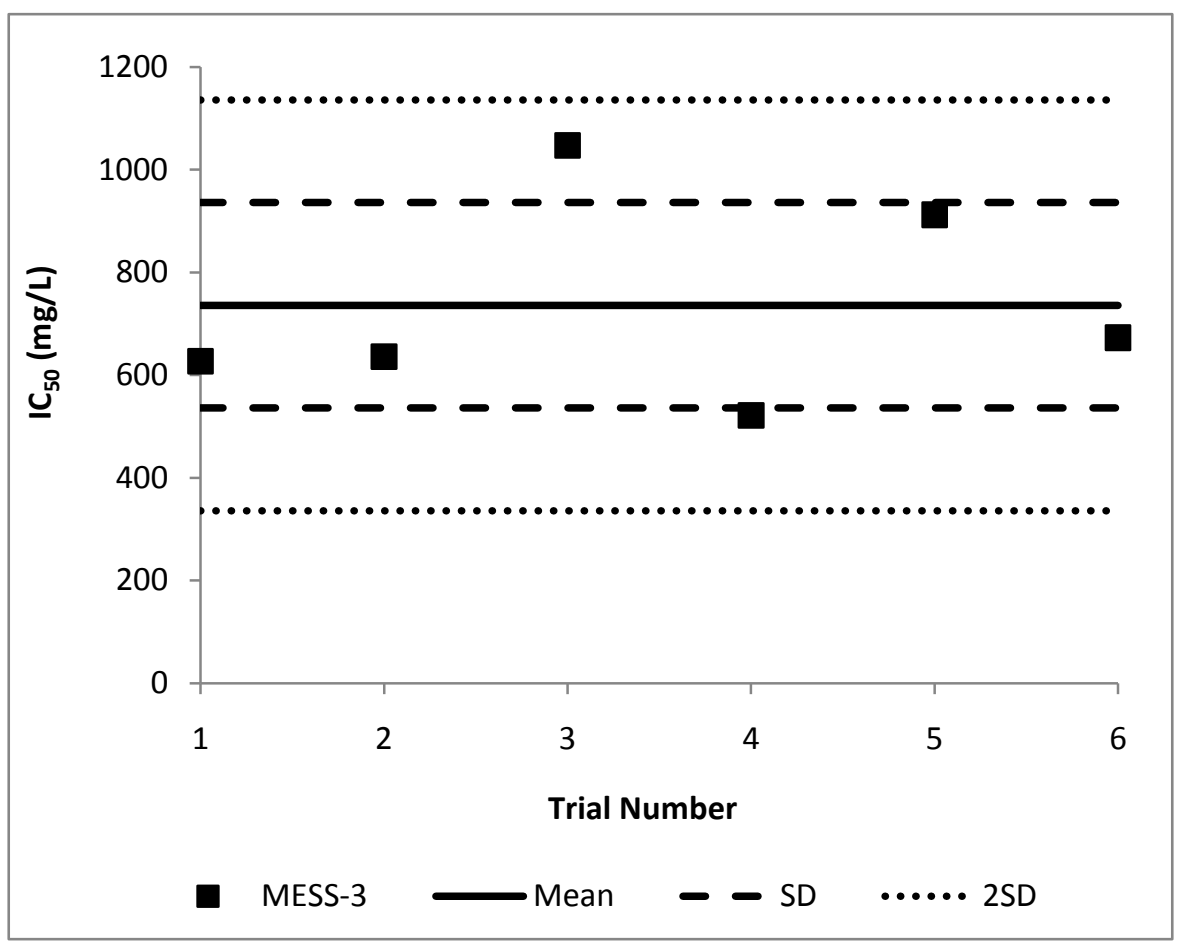

Figure D1: Quality control chart for analysis of MESS-3 using Microtox ${ }^{\mathrm{TM}}$ solid phase test 
Table D1: Measurement of the precision of total metal concentrations in water samples using ICP-OES by comparison of duplicate analysis on two different instruments

\begin{tabular}{|c|c|c|c|c|c|c|c|c|c|c|c|c|c|c|c|c|c|c|c|}
\hline \multirow{2}{*}{ Sample ID } & & \multicolumn{18}{|c|}{ Total Metal Concentration (mg/L) } \\
\hline & & Al & As & $\mathbf{B a}$ & Be & B & Cd & Ca & Co & $\mathrm{Cu}$ & Fe & Mg & Mn & Mo & Ni & $\mathbf{P b}$ & Se & TI & $\mathbf{Z n}$ \\
\hline \multirow{3}{*}{ H1A-A } & EOS & 0.80 & ND & 0.02 & ND & 0.04 & ND & 9.72 & ND & 0.042 & 0.061 & 1.11 & ND & ND & ND & ND & ND & ND & ND \\
\hline & $\mathrm{EE}$ & 0.87 & ND & ND & ND & ND & ND & 9.99 & ND & 0.037 & 0.055 & 1.16 & 0.016 & ND & ND & ND & ND & ND & ND \\
\hline & Ratio & 1.08 & & & & & & 1.03 & & 1.114 & 1.115 & 1.05 & & & & & & & \\
\hline \multirow{3}{*}{ H1A-B } & EOS & 0.03 & ND & 0.02 & ND & 0.15 & ND & 9.53 & ND & 0.032 & 0.051 & 1.08 & ND & ND & 0.022 & ND & ND & ND & $\mathrm{ND}$ \\
\hline & $\mathrm{EE}$ & 0.06 & ND & ND & ND & ND & ND & 9.29 & ND & 0.026 & 0.043 & 1.08 & 0.015 & ND & ND & ND & ND & ND & ND \\
\hline & Ratio & 1.71 & & & & & & 1.03 & & 1.222 & 1.197 & 1.00 & & & & & & & \\
\hline \multirow{3}{*}{ H1 A-C } & EOS & $\mathrm{ND}$ & ND & 0.02 & ND & ND & ND & 9.45 & ND & 0.028 & 0.040 & 1.07 & ND & ND & 0.023 & ND & ND & ND & $\mathrm{ND}$ \\
\hline & $\mathrm{EE}$ & 0.03 & ND & ND & ND & ND & ND & 9.06 & ND & 0.021 & 0.027 & 1.06 & 0.017 & ND & ND & ND & ND & ND & ND \\
\hline & Ratio & & & & & & & 1.04 & & 1.347 & 1.453 & 1.01 & & & & & & & \\
\hline \multirow{3}{*}{ H1B } & EOS & ND & ND & 0.02 & ND & ND & ND & 9.27 & ND & 0.035 & 0.032 & 1.01 & ND & ND & 0.021 & ND & ND & ND & 0.012 \\
\hline & $\mathrm{EE}$ & 0.024 & ND & ND & ND & ND & ND & 9.10 & ND & 0.028 & 0.019 & 1.01 & 0.004 & ND & ND & ND & ND & ND & ND \\
\hline & Ratio & & & & & & & 1.02 & & 1.231 & 1.715 & 1.00 & & & & & & & \\
\hline \multirow{3}{*}{$\mathrm{H} 2$} & EOS & 0.91 & ND & 0.02 & ND & ND & 0.004 & 12.09 & ND & 0.041 & 0.129 & 2.12 & 0.168 & ND & 0.042 & ND & ND & ND & 0.228 \\
\hline & $\mathrm{EE}$ & 0.95 & ND & ND & ND & ND & ND & 12.13 & ND & 0.036 & 0.130 & 2.13 & 0.185 & ND & ND & ND & ND & ND & 0.222 \\
\hline & Ratio & 1.05 & & & & & & 1.00 & & 1.148 & 1.007 & 1.00 & 1.100 & & & & & & 1.028 \\
\hline \multirow{3}{*}{ H3-A } & EOS & 0.92 & ND & 0.02 & ND & ND & 0.006 & 17.72 & 0.006 & 0.045 & 0.087 & 4.59 & 0.349 & ND & 0.044 & ND & ND & ND & 0.392 \\
\hline & $\mathrm{EE}$ & 0.94 & ND & ND & ND & ND & ND & 15.96 & 0.005 & 0.039 & 0.077 & 3.61 & 0.346 & ND & 0.011 & ND & ND & ND & 0.380 \\
\hline & Ratio & 1.02 & & & & & & 1.11 & 1.161 & 1.152 & 1.122 & 1.27 & 1.008 & & 3.925 & & & & 1.031 \\
\hline \multirow{3}{*}{ H3-B } & EOS & 0.92 & ND & 0.02 & ND & 0.04 & 0.006 & 17.81 & 0.006 & 0.038 & 0.087 & 4.59 & 0.347 & ND & 0.044 & ND & ND & ND & 0.391 \\
\hline & $\mathrm{EE}$ & 0.98 & ND & ND & ND & ND & ND & 15.90 & 0.006 & 0.031 & 0.078 & 3.60 & 0.353 & ND & 0.011 & ND & ND & ND & 0.379 \\
\hline & Ratio & 1.06 & & & & & & 1.12 & 1.103 & 1.215 & 1.109 & 1.27 & 1.017 & & 3.833 & & & & 1.033 \\
\hline \multirow{3}{*}{$\mathrm{H} 3-\mathrm{C}$} & EOS & 0.94 & ND & 0.02 & ND & 0.07 & 0.006 & 17.61 & 0.006 & 0.037 & 0.090 & 4.25 & 0.354 & ND & 0.044 & ND & ND & ND & 0.398 \\
\hline & $\mathrm{EE}$ & 0.98 & ND & ND & ND & ND & ND & 16.60 & 0.006 & 0.031 & 0.083 & 3.76 & 0.357 & ND & 0.013 & ND & ND & ND & 0.391 \\
\hline & Ratio & 1.04 & & & & & & 1.06 & 1.088 & 1.203 & 1.088 & 1.13 & 1.010 & & 3.411 & & & & 1.018 \\
\hline \multirow{3}{*}{$\mathrm{P} 2$} & EOS & $\mathrm{ND}$ & ND & 0.02 & ND & 0.13 & ND & 6.89 & ND & 0.025 & 0.040 & 1.49 & ND & ND & 0.012 & ND & ND & ND & $\mathrm{ND}$ \\
\hline & $\mathrm{EE}$ & 0.03 & ND & ND & ND & ND & ND & 6.48 & ND & 0.017 & 0.028 & 1.49 & 0.005 & ND & ND & ND & ND & ND & ND \\
\hline & Ratio & & & & & & & 1.06 & & 1.436 & 1.405 & 1.00 & & & & & & & \\
\hline \multirow{3}{*}{ P1 } & EOS & 0.18 & ND & 0.02 & ND & 0.06 & ND & 5.18 & ND & 0.036 & 0.097 & 1.15 & ND & ND & ND & ND & ND & ND & $\mathrm{ND}$ \\
\hline & $\mathrm{EE}$ & 0.20 & ND & ND & ND & ND & ND & 5.08 & ND & 0.030 & 0.097 & 1.15 & 0.006 & ND & ND & ND & ND & ND & ND \\
\hline & Ratio & 1.13 & & & & & & 1.02 & & 1.187 & 1.008 & 1.00 & & & & & & & \\
\hline \multirow{3}{*}{ P3 } & EOS & $\mathrm{ND}$ & ND & 0.01 & ND & 0.08 & ND & 10.05 & ND & 0.032 & 0.027 & 0.81 & ND & ND & 0.012 & ND & ND & ND & $\mathrm{ND}$ \\
\hline & $\mathrm{EE}$ & 0.01 & ND & ND & ND & ND & ND & 9.30 & ND & 0.024 & 0.011 & 0.78 & 0.003 & ND & ND & ND & ND & ND & ND \\
\hline & Ratio & & & & & & & 1.08 & & 1.342 & 2.491 & 1.05 & & & & & & & \\
\hline \multirow{3}{*}{$\mathrm{P} 4$} & EOS & 0.04 & ND & 0.02 & ND & ND & ND & 11.60 & ND & 0.025 & 0.129 & 1.45 & 0.014 & ND & 0.017 & ND & ND & ND & 0.020 \\
\hline & $\mathrm{EE}$ & 0.06 & ND & ND & ND & ND & ND & 11.00 & ND & 0.017 & 0.133 & 1.46 & 0.039 & ND & ND & ND & ND & ND & ND \\
\hline & Ratio & 1.65 & & & & & & 1.05 & & 1.436 & 1.024 & 1.01 & 2.715 & & & & & & \\
\hline Average Ratio & & 1.22 & & & & & & 1.05 & 1.12 & 1.25 & 1.31 & 1.07 & 1.37 & & 3.72 & & & & 1.03 \\
\hline
\end{tabular}

EOS - Earth and Ocean Sciences ICP-OES EE - Environmental Engineering ICP-OES ND - not detected 